Pontifícia Universidade Católica $_{\text {Do Rio de Janeiro }}$

Fabiana Oliveira Heinrich

Crítica da experiência como mercadoria no Campo do Design

Tese de Doutorado

Tese apresentada ao Programa de Pós-Graduação em Design da PUC-Rio como requisito parcial para obtenção do grau de Doutor em Design.

Orientador: Prof. Alberto Cipiniuk 


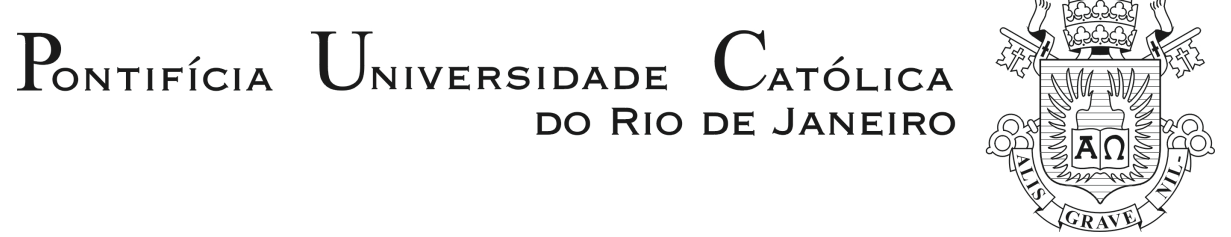

Fabiana Oliveira Heinrich

\section{Crítica da experiência como mercadoria no Campo do Design}

Tese apresentada ao Programa de Pós-Graduação em Design da PUC-Rio como requisito parcial para obtenção do grau de Doutor em Design. Aprovada pela Comissão Examinadora abaixo assinada.

Prof. Alberto Cipiniuk Orientador Departamento de Artes \& Design - PUC-Rio

Profa. Denise Berruezo Portinari Departamento de Artes \& Design - PUC-Rio

Profa. Irina Aragão dos Santos Departamento de Artes \& Design - PUC-Rio

Prof. Marcelo Vianna Lacerda de Almeida

Universidade Federal de Juiz de Fora - UFJF

Prof. Iraldo Alberto Alves Matias Universidade Federal de Santa Catarina - UFSC

Profa. Monah Winograd Coordenadora Setorial do Centro de Teologia e Ciências Humanas - PUC-Rio

Rio de Janeiro, 13 de Abril de 2018 
Todos os direitos reservados. É proibida a reprodução total ou parcial do trabalho sem autorização da universidade, da autora e do orientador.

\section{Fabiana Oliveira Heinrich}

Mestre em Design pela Pontifícia Universidade Católica do Rio de Janeiro - PUC-Rio (2013) e Bacharel em Design Gráfico pela Universidade Federal de Pelotas - UFPEL (2008). Durante o doutorado, foi pesquisadora visitante no Department of German Studies da Brown University (2015), pelo programa de convênio PUC-Rio - Brown University, e realizou doutorado-sanduiche no Department of History of Art + Visual Culture da Rhode Island School of Design RISD (2017-2018), pelo programa PDSE-CAPES. Foi professora substituta do Curso de Design Gráfico da supracitada UFPEL (2008-2009) e tem experiência em projetos de Design Digital e Gráfico como freelancer e nas empresas Conrad Caine GmbH (2009-2013) e Nodo (20132014).

Ficha Catalográfica

Heinrich, Fabiana Oliveira

Crítica da experiência como mercadoria no Campo do Design / Fabiana Oliveira Heinrich; orientador: Alberto Cipiniuk - 2018.

202 f.: il. (color.); $30 \mathrm{~cm}$

Tese (Doutorado) - Pontifícia Universidade Católica do Rio de Janeiro, Departamento de Artes e Design, 2018.

Inclui bibliografia

1. Artes e Design - Teses. 2. Campo do Design.

3. Crítica. 4. Experiência. 5. Mercadoria. I. Cipiniuk, Alberto. II. Pontifícia Universidade Católica do Rio de Janeiro. Departamento de Artes \& Design. III. Título. 
Para Carmen e Paulo

— infindavelmente - 


\section{Agradecimentos}

Foram muitas as pessoas e instâncias envolvidas nestes quatro anos de trabalho, às quais devo agora meu sincero agradecimento.

Agradeço ao Departamento de Artes e Design da PUC-Rio pela possibilidade de desenvolvimento deste estudo, sobretudo pelo imprescindível financiamento através das bolsas VRAC e CAPES. Devo agradecer ainda ao programa de convênio PUC-Rio - Brown University pela bolsa de pesquisadora visitante, que me propiciou uma estadia de estudo e pesquisa na Brown University; bem como ao programa PDSE-CAPES pela bolsa de doutorado-sanduíche, com a qual pude retornar à Providence para mais um período de estudo e pesquisa, desta vez na Rhode Island School of Design - RISD.

De sobremaneira agradeço ao Prof. Alberto Cipiniuk, orientador que me ensinou a pensar criticamente, além de constituir exemplo do mais elevado padrão intelectual. O pensamento crítico é um caminho sem volta, uma marca indelével e indomável, que espero ter a capacidade de levar adiante. Minha dívida é grande pela amizade, o apoio, a confiança e a paciência dispendidos nestes seis anos de trabalho conjunto, desde o mestrado.

Agradeço ao Prof. Ijlal Muzaffar, co-orientador durante o período de doutorado-sanduiche no Department of History of Art + Visual Culture da Rhode Island School of Design - RISD. A disciplina cursada e as reuniões para discussão da pesquisa foram vitais para o que apresentaremos a seguir. Ainda, agradeço ao Prof. Gerhard Richter, que tão bem me recebeu no Department of German Studies da Brown University, por todos os ensinamentos na disciplina sobre crítica e pelas indicações bibliográficas.

Aos professores da banca, Profa. Denise Berruezo Portinari, Profa. Irina Aragão dos Santos, Prof. Iraldo Alberto Alves Matias e Prof. Marcelo Vianna Lacerda de Almeida, agradeço o interesse em avaliar e debater este trabalho. A leitura atenta e os comentários — já na qualificação — edificaram e edificam este 
estudo, que não é pensado individualmente. À Profa. Irina Aragão dos Santos, agradeço ainda pela substancial amizade.

Devo agradecer também ao Pedro Alcântara Figueira por me guiar através das leituras de algo até então estranho a mim - a Economia Política. Os e-mails com inquietações foram primordiais para o avanço do que foi pensado nesta pesquisa. Agradeço ainda aos colegas do grupo de estudos das manhãs de segundafeira e aos colegas do GRUDAR, pela construção conjunta de conhecimento.

Agradeço aos professores da Rhode Island School of Design - RISD, que com grande interesse me atenderam quando solicitei reuniões para discutir esta pesquisa, fazendo perguntas pertinentes, indicando bibliografia e sugerindo percursos profissionais: Profa. Alero Akporiaye, Profa. Maya Krinsky e Profa. Namita Vijay Dharia. Agradeço também ao Prof. Damian White, Prof. Edek Sher, Prof. Matthew Kenyon e Profa. Rachel Silberstein, por permitirem minha participação em disciplinas como aluna ouvinte e por também terem debatido comigo o tema desta tese. Ao Prof. Eric Anderson, agradeço a possibilidade de ter falado à sua turma, bem como também ter indicado bibliografia e discutido o tema da tese. Agradeço à Catherine Sacco e Margaret Lewis pelas resoluções burocráticas e conversas amistosas de boas-vindas e de acompanhamento na RISD. Ainda, agradeço à Emily Coxxe, pela orientação na Fleet Library - RISD.

Agradeço aos funcionários do Departamento de Artes e Design da PUCRio, sobretudo Diego Pimenta e Romário César, pelos também auxílios burocráticos na realização desta pesquisa.

Aos colegas que ingressam no curso de Doutorado em 2014, agradeço o convívio afortunado. À Cristiana Fernandes (Kitty), agradeço a amizade sincera e o contraponto espirituoso em nossas discussões.

Aos amigos e colegas Joana Contino e Wilson Prata, agradeço as discussões teórico-práticas e o compartilhamento de anseios, alegrias e bibliografia. À Laura Gouvêa e Thalita Campbell, agradeço pela valorosa amizade que começou no mestrado e que foi me visitar lá em Providence, em uma semana memorável. Ainda à Laura Gouvêa, agradeço imensamente pela pronta disponibilidade em me receber com tanta amizade em um lar que transborda beleza e sensibilidade. À amiga Ana Helena da Fonseca, agradeço a presença constante e encorajadora. 
Agradeço aos amigos de Providence, que tornaram os dois períodos de estadia inesquecíveis: Anastasia Tsylina, Christian Obst, Daniel Ada e Zohar Frank. Ainda, ao querido e singular grupo luso-brasileiro, que acalentou um outono e inverno gélidos: Abner Sótenos, Antônio Sanseverino, Flavia Soares, Gabriela Semensato e Rita Almeida de Carvalho.

À Roberta Manaa, agradeço pela forte amizade que se firmou em 2011 e que resultou em uma maravilhosa convivência dividindo um quarto! Agradeço ainda à Marcia Brito pela animada acolhida em sua casa, bem como à Karishma Goradia, por todos os novos sabores e perspectivas culturais.

Às designers doutorandas espalhadas pelo globo, Chris de Azevedo Ramil, Daniela Brisolara e Renata Gastal, agradeço pela excepcional amizade de longa data, pelo apoio e as trocas, sobretudo nas etapas finais deste trabalho.

Agradeço ao Marcelo Maraninchi pela generosa amizade e por compartilhar inquietações e referências — die Deutschen! — que nos fazem ir em frente e além.

Por fím, devo muito à minha família. Agradeço à "dinda" Sônia, pelo interesse genuíno e por ter suscitado, desde a infância, uma curiosidade que me fez tomar o rumo das Artes/ Design e da academia. Aos meus irmãos Juliana e Roberto, pelo amor, apoio, compreensão e presença constantes, seja em Pelotas ou em qualquer lugar. Agradeço ainda à Juliana e ao Alex por todas as valorosas hospedagens em Porto Alegre, bem como ao pequeno Felipe - o futuro. Por fim, aos meus pais, Carmen e Paulo, pelo amor, apoio, compreensão, dedicação e suporte incondicionais durante todo o percurso, mas principalmente nesta reta final. Ainda, por terem sempre colocado a nossa educação em primeiro lugar. Maior e melhor exemplo não há. 


\section{Resumo}

Heinrich, Fabiana Oliveira; Cipiniuk, Alberto (Orientador). Crítica da experiência como mercadoria no Campo do Design. Rio de Janeiro, 2018. 202p. Tese de Doutorado - Departamento de Artes e Design, Pontifícia Universidade Católica do Rio de Janeiro.

Nesta tese examinamos a experiência como mercadoria no Campo do Design. Argumentamos que a noção de experiência adotada é acrítica e equivocada, posto que evoca um determinismo tecnológico quando deveria reconhecê-la como uma construção social, isto é, algo constituído historicamente, que evidencia a ideologia do contexto e as idiossincrasias daquele que experiencia. Logo, investigando a questão pelo viés da Crítica Social, principiamos o estudo pela definição de experiência no Campo do Design através de duas vertentes identificadas - a vertente teórica humanista e a vertente orientada pelo mercado. A seguir, ampliamos este entendimento com conceitos do Campo da Filosofia. Em seguida, partimos para a definição de mercadoria e sua condição no capitalismo tardio. Esclarecemos sua forma elementar - que persiste contemporaneamente - , bem como as implicações da expansão do capitalismo, que provocou mudanças nas esferas da produção e da circulação, as quais influenciaram e influenciam o Campo do Design. Por fim, discutimos se a experiência no Campo do Design pode, de fato, carregar este nome, e se ela é uma mercadoria. Nesta discussão, postulamos que o Campo não projeta a/para a experiência, tendo em vista que não reconhece os limites de sua práxis - ele ainda projeta objetos e seus modos de uso, e não experiências - nem as idiossincrasias de quem experiencia. Consequentemente, uma experiência não pode ser uma mercadoria, pois não é projetada, e também porque não se encaixa na forma elementar. Assim, propomos que o que o Campo comercializa consiste apenas de promessas - promessas de um uso ou experiência que pode ou não se cumprir - ou apenas um valor simbólico.

\section{Palavras-chave}

Campo do Design, crítica, experiência, mercadoria. 


\section{Abstract}

Heinrich, Fabiana Oliveira; Cipiniuk, Alberto (Advisor). Critique of experience as a commodity in the Design Field. Rio de Janeiro, 2018. 202p. Tese de Doutorado - Departamento de Artes e Design, Pontifícia Universidade Católica do Rio de Janeiro.

In this dissertation we examine experience as a commodity in the Design Field. We argue that the notion of experience employed in the Field is acritical and incorrect, because it evokes a technological determinism when it should recognize it as a social construct, that is, something that is historically built, which manifests the context's ideology and the experience holder's idiosyncrasies. Therefore, to examine this via the Social Criticism bias, we first define what experience means in the Design field with two identified strands - one called theoretical humanist, and the other market oriented. After that, we extend our experience understanding with concepts from the Philosophy Field. Following, we define the meaning of commodity and its condition in late capitalism. We clarify its elemental form which persists in contemporaneity - as well as the implications of capitalism expansion, which caused changes in the spheres of production and circulation that influenced and still influences the Design Field. At last, we discuss if what is considered experience in the Design Field can really hold this name, and if it really is a commodity. In this discussion, we propose that the Field doesn't design, or design for, an experience, because it doesn't acknowledge the limits of its praxis it still designs objects and their modes of use, not experiences - nor the experience holder's idiosyncrasies. Consequently, experience can't be a commodity, because it can't be designed and also because it doesn't fit to the commodity elemental form. In this way, we theorize that what the Design Field commercializes are only promises - promises of use or experience that might not occur — or simply a symbolic value.

\section{Keywords}

Design Field, critique, experience, commodity. 


\section{Sumário}

1. INTRODUÇÃO 12

$\begin{array}{ll}\text { 2. DA EXPERIÊNCIA } & 19\end{array}$

2.1. Design de Experiência: vertente teórica humanista ou 19 orientada pelo mercado?

2.1.1. Vertente teórica humanista 22

2.1.2. Vertente orientada pelo mercado 34

2.1.3. O que é, afinal, Design de Experiência? 47

2.1.3.1. Definições experienciais 49

2.1.3.2. Como projetar a/para a experiência? 64

2.1.3.3. Avaliações e resultados experienciais 75

2.2. Variações sobre um tema universal 81

2.2.1. Etimologia 84

2.2.2. A experiência estética e o Pragmatismo 87

2.2.3. A crise da experiência na Escola de Frankfurt 93

$\begin{array}{ll}\text { 2.2.4. A estrutura e a ausência do sujeito } & 100\end{array}$

3. DA MERCADORIA 109

3.1. A forma elementar 111

3.2. Metamorfoses históricas 121

3.2.1. Industrializando o sensível 122

3.2.2. Novos modos de acumulação 130

3.2.3. A mercadoria "pós-moderna" 143

3.2.4. Mercadorias ou produtos? A querela no Campo do Design 151

3.3. Metamorfoses contemporâneas 156

$\begin{array}{ll}\text { 3.3.1. Manipulando felicidade } & 156\end{array}$

$\begin{array}{lr}\text { 3.3.2. Obsolescência e virtualidade } & 162\end{array}$ 
4. CRÍTICA DA EXPERIÊNCIA COMO MERCADORIA NO CAMPO DO DESIGN

4.1. Projetando ainda formas e usos

4.2. Vendendo promessas

5. CONCLUSÃO

6. Referências bibliográficas 
1.

\section{INTRODUÇÃO}

Em julho de 1967, Theodor Adorno foi chamado à Freie Universität Berlin para proferir uma palestra. ${ }^{1} \mathrm{O}$ tema escolhido, o Classicismo em Goethe, mais especificamente na obra Ifigênia em Tauris (Iphigenie auf Tauris), foi veemente criticado e abruptamente interrompido pela audiência, especialmente alunos, que esperavam ouvir, naquela ocasião, a opinião do filósofo acerca da crise política na Alemanha Ocidental. Protestos estudantis, tendências monopolistas na mídia e uma crise educacional tomavam forma, especialmente em virtude do apoio alemão à Guerra no Vietnã e da morte de um estudante por um policial - mais tarde absolvido - em uma manifestação contra a visita do Xá da Pérsia, acusado de “ditador cliente" dos Estados Unidos. Em resposta à crítica, Adorno afirmou que não havia nada mais político do que falar de literatura em um momento como aquele, tendo em vista que manifestações humanas estéticas aparentemente apolíticas são, na verdade, ideológicas, isto é, reproduzem pensamentos e valores das ordens e instituições sociais existentes, principalmente as dominantes. Mais especificadamente na obra em questão, relações de violência e razão, passado e presente, poder do Estado e ação individual são abordadas, evidenciando a proximidade entre o pensamento filosófico e a ação política.

Começamos este trabalho evocando o episódio ocorrido com Adorno e sua audiência porque nesta tese trataremos da noção de experiência no Campo do $D_{e s i g n}{ }^{2}$, a qual, para os desavisados, aparece apenas como mais uma possibilidade da práxis do Campo em "inovar" — sobretudo a partir do emprego de novas tecnologias - e "melhorar"3 as nossas vidas. Entretanto, por trás deste

\footnotetext{
${ }^{1}$ Notas do curso What is Critique, ministrado pelo Prof. Gerhard Richter, de setembro a dezembro de 2015 no Department of German Studies, Brown University. Também, ver: WIGGERSHAUS, Rolf. The Frankfurt School: Its History, Theories, and Political Significance. MIT Press, 1994.

2 Utilizamos o termo Design em itálico por entendermos que este estrangeirismo tem peso ideológico, sobretudo ao nomear uma prática social confusamente definida no Brasil.

${ }^{3}$ Em fala intitulada "Better", proferida no evento Better World by Design 2017, em Providence (EUA), Alexandra Ginsberg discutiu como algumas práticas do Campo do Design se apropriam do
} 
entendimento de inovação e melhoria, há um grande peso político, o qual queremos investigar e evidenciar neste trabalho.

Assim, é neste sentido — o da investigação de relações por vezes sem aparência evidente - que direcionamos o estudo que aqui toma forma sobre a noção de experiência no Campo do Design, mais precisamente sobre o entendimento desta como mercadoria. Concebida sobretudo a partir de um determinismo tecnológico - velado sob o discurso de uma preocupação humanista, na qual a experiência seria apenas algo abstrato, emocional, individual, não copiável - a experiência, ou o Design de Experiência, como é comumente nomeada, é tida como algo passível de ser projetado, ou que de um projeto advenha sua ocorrência. Entretanto, aqui já encontramos um paradoxo: como projetar algo ou projetar para algo descrito como abstrato, emocional, genuíno, individual, não copiável, tendo em vista que um projeto resulta em algo concreto, racional, copiável, coletivo? Ainda, no Campo do Design - como em qualquer outra profissão - projetos são desenvolvidos com o intuito de gerar lucro, e não apenas como benevolência humanista. Deste modo, ao considerarmos a experiência como comercializável, entende-se que essa se torna uma mercadoria. Contudo, novamente, como considerar algo abstrato, emocional, genuíno, individual, não copiável como uma mercadoria, algo que se assemelha à concretude, racionalidade, copiabilidade e coletividade do projeto? São esses os questionamentos que orientam o desenvolvimento deste trabalho.

Assim, para buscar respostas a essas perguntas, organizamos o estudo em três frentes: Capítulo 2 - Da experiência, Capítulo 3 - Da mercadoria e Capítulo 4 Crítica da experiência como mercadoria no Campo do Design. No Capítulo $2-D a$ experiência, buscamos definir o que é isso que é considerado experiência no Campo do Design. A partir da leitura de escritos ${ }^{4}$ de designers e teóricos do Campo, com textos publicados sobretudo a partir de 1998, quando o termo Economia da Experiência foi cunhado, identificamos duas vertentes de entendimento. Uma que

termo "better" (melhor, melhorar) para descrever seus objetivos e resultados. A pesquisadora questiona as possibilidades do "melhor": o que significa ser "melhor", em que medida esses resultados são, de fato, melhores, para quem o são e quem decide o que é "melhor". Sua investigação se concentra na relação entre o Campo do Design e a biologia sintética, mas ela iniciou sua fala com um exemplo bem simples, o da garrafa d'água plástica, que é economicamente lucrativa, porém um desastre para o meio ambiente e, neste sentido, podemos considerá-la "melhor"? Notas da autora.

${ }^{4}$ Grande parte dos escritos empregados sobre Design de Experiência estão em língua inglesa. Todas as traduções são da autora, salvo quando indicado. 
nomeamos vertente teórica humanista e outra orientada pelo mercado. Apesar de parecerem contraditórias, se complementam, sobretudo com a primeira servindo como base conceitual para a segunda. A vertente teórica humanista postula a capacidade da práxis do Campo do Design, sobretudo através de projetos digitais, de projetar a/para a experiência, com o intuito de melhorar a nossa interação e uso de produtos e até mesmo proporcionar-nos uma experiência holística, ou seja, que ultrapasse os limites do uso do produto. Já a vertente orientada pelo mercado advoga pela capacidade do Campo do Design de contribuir para essa nova economia - a Economia da Experiência - , que seria resultado de uma crescente demanda, por parte de consumidores, de distintas maneiras, sobretudo intangíveis, de satisfazer suas "necessidades". A partir do entendimento dos textos e desta classificação, pudemos perceber que a experiência, no Campo do Design, pouco quiçá nada - tem de humanista, sendo determinada prioritariamente pelos objetos tecnológicos através dos quais ela ocorre e, sendo a tecnologia orientada pelo capital, em última instância, a experiência encontra-se também orientada por este. Ainda, ao buscar compreender como se projeta isto que é chamado de experiência no Campo do Design, verificamos que praticamente todos os projetos se calcam no desenvolvimento do objeto ou do serviço oferecido a partir do qual a experiência ocorre e, neste sentido, é possível afirmar, então, que os projetos tomam conta de outras frentes, e não da experiência. Em um segundo momento, buscamos ampliar nosso entendimento da noção de experiência para além-Campo do Design, posto que este é um conceito de grande relevância para o conhecimento humano, uma vez que baliza sua construção e nosso cotidiano o tempo todo. Com este estudo alémCampo - em que recorremos ao Campo da Filosofia e seu mapeamento desde os gregos para a explicação de um termo tão relevante - pudemos perceber a complexidade do termo experiência e os distintos sentidos que este já teve através da história e das condições materiais de vida humana, os quais são ignorados pelo Campo do Design. Ainda, o Campo em questão parece desconsiderar as dimensões idiossincráticas e subjetivas de seus usuários, posto que um projeto não pode dar conta do que escapa aos seus limites de ação. Com efeito, nos questionamos em que medida isso que o Campo do Design projeta/projeta para é mesmo uma experiência, e se é possível projetar para algo tão complexo que parece se esquivar da capacidade da práxis do Campo. 
No Capítulo 3 - Da mercadoria, buscamos entender o que define uma mercadoria, procurando compreender seu modo de funcionamento e relevância na sociedade capitalista. Para isto, recorremos a escritos que definem sua forma elementar no final do século XIX e o desdobramento de seu entendimento através do século XX, investigando sua aproximação com a Cultura, as Artes e o Design, e recaindo no questionamento acerca da condição das produções desses campos como mercadorias. Recorremos ainda a escritos que discorrem sobre as mudanças nas esferas de produção e circulação do capitalismo, os novos modos de acumulação no que se pode chamar de capitalismo tardio, e o contemporâneo surgimento do que é cunhado de Indústria da Felicidade e da comercialização de instâncias intangíveis - discussões em completa sintonia com o Campo do Design, tendo em vista sobretudo as produções digitais que definem isso que chamam de Design de Experiência. Para este entendimento, recorremos à noção de "comodificação", a qual nos fornece um caminho para a diferenciação entre comercialização, ou seja, a atribuição de valor de mercado a serviços e objetos que não são mercadorias, e a mercadoria em si. Ainda, discutimos a querela produto versus mercadoria no Campo do Design, evidenciando o peso ideológico por trás dos termos empregados no Campo em questão - e aqui podemos pensar no peso ideológico do termo experiência também. Buscamos evidenciar como chegamos ao status quo instaurado, principalmente no que se refere à conjunção de um mercado global, um capitalismo crescentemente financeiro e uma ampliação da divisão do trabalho em distintos setores, os quais moldam as práticas contemporâneas do Campo em questão. Diante deste entendimento, questionamos: pode a experiência no Campo do Design ser uma mercadoria?

Por fim, no Capítulo 4 - Crítica da experiência como mercadoria no Campo do Design, apresentaremos, como o próprio título já descreve, uma crítica da experiência como mercadoria no Campo do Design, postulando o resultado do nosso estudo. A partir da investigação da noção de experiência no Campo do Design, que tem sua definição determinada tecnologicamente e que se mostra insatisfatória diante dos requerimentos do próprio Campo para projetar uma experiência mais holística, pudemos observar que não é possível projetar a/para a experiência. Discutimos as noções que formam esse discurso, como usuário e uso, e postulamos que a ideia de usuário é uma vertigem - no máximo, talvez, projetamos $o$ usuário, mas não para ele. Ainda, o projeto do/para o uso também 
pode apresentar inconsistências, tendo em vista as idiossincrasias, contextos e outras frentes que englobam sua ocorrência. Assim, se o Campo do Design não pode projetar a/para a experiência, o que é que ele comercializa? Só podemos chegar à conclusão de que vende promessas, promessas de que determinado uso e determinada experiência ocorrerão. E tais promessas vêm sempre através de um objeto de Design — talvez uma mercadoria - ou de um serviço, ou seja, ela não existe por si só. Além disso, as promessas podem ser entendidas também como um valor simbólico, algo que propicia distinção a quem o possui ou consome - e esse é, grande parte das vezes, um dos principais fatores que influenciam a compra e/ou uso de determinado objeto ou serviço.

Devemos aqui evidenciar também como concebemos o Campo do Design: para nós, seguindo a definição proposta por Alberto Cipiniuk ${ }^{5}$, Design consiste de uma produção social, ou seja, uma prática social, laborativa, contextualizada em determinado espaço-tempo - aqui, a contemporaneidade cultural, econômica, política e social do modo de produção capitalista em seu estágio contemporâneo , que compreende seus limites de forma crítica, buscando evidenciar estruturas que foram naturalizadas. Ainda, em consonância com a definição de Design como produção social, esclarecemos que nossa orientação crítica é aquela da Crítica Social e do Materialismo Histórico, o qual busca compreender a raison d'être e o modus operandi da sociedade a partir do estudo dos meios pela qual essa mesma sociedade produz suas condições de existência.

Além disso, acreditamos que vale apresentar um breve relato - talvez justificativa - da escolha por este tema. Desde 2008, trabalho ${ }^{6}$ - tanto em escritórios como com projetos freelance - com Design Digital e, consequentemente, projetos de Design de Experiência. Iniciei minha vida profissional em um escritório internacional de Design Digital, à época chamado Conrad Caine, em Pelotas, Rio Grande do Sul, logo após a conclusão do curso de Design Gráfico na Universidade Federal de Pelotas, em 2008. Foi lá que tive contato, pela primeira vez, com o termo Design de Experiência, principalmente

\footnotetext{
${ }^{5}$ CIPINIUK, Alberto. Design: o livro dos porquês: o campo do Design compreendido como produção social. Rio de Janeiro: Ed. PUC-Rio; São Paulo: Ed. Reflexão, 2014.

${ }^{6}$ Utilizamos aqui a primeira pessoa do singular, por tratarmos de eventos ocorridos somente na vida da autora. Durante o texto da tese como um todo, utilizamos a primeira pessoa do plural, visto que estamos pensando conjuntamente.
} 
através do uso da designação de $U X$ designer (user experience designer), nomenclatura que é adotada em inglês até hoje nos escritórios brasileiros. O $U X$ designer é o profissional responsável por projetar a experiência do usuário em projetos digitais. Recordo-me de àquela época já me questionar se era possível, de fato, projetar uma experiência, e se aquilo que projetávamos - aplicativos, websites, sistemas interativos - poderia ser chamado de experiência, ou que relação poderia ter com uma experiência. Ainda, eu me questionava acerca da aplicação do que lia em livros, principalmente no que tange a métodos de projeto para a experiência, metodologias projetuais $^{7}$ a serem seguidas; e do que eu vivenciava no cotidiano da empresa, no qual pouco do que a teoria apresentava era posto em prática, como uma total negação de pesquisa com o usuário, não obstante este seja o norte dos projetos investigados. Além disso, ainda hoje, em conversas com colegas atuantes no mercado, verificamos que pouco dos modelos e diretrizes apresentados teoricamente são seguidos, pois, não tão magicamente, o tempo do mercado é outro. Logo, foi a partir dessas vivências - experiências -, questionamentos e, posteriormente, estudos de teoria crítica desenvolvidos durante o Mestrado e o Doutorado junto ao LaRS (Laboratório da Representação Sensível) e ao GRUDAR (Grupo de Estudos Design, Arte e Representação Social), na PUCRio; e junto também do Department of German Studies da Brown University e do Department of History of Art + Visual Culture da Rhode Island School of Design (RISD), onde realizei doutorado-sanduiche, que a problematização e o desenvolvimento deste estudo tomaram forma.

Por fim, fazendo jus ao tema desta tese e aos percursos de tempo e espaço por ela percorridos, faz sentido lembrarmos de Martin Jay (2006) e pensarmos na experiência de escrevê-la. Comumente, a introdução é a última parte a ser escrita, e ela implica na concretização de linhas que, ao início da pesquisa, não estavam esboçadas nem no pensamento do pesquisador. Porém, essas linhas propiciam agora uma retrospectiva coerente do que nem sempre estava ordenado, apagando os traços

\footnotetext{
${ }^{7}$ Em dissertação de mestrado, desenvolvemos um estudo crítico da noção de metodologia de projeto no Campo do Design, evidenciando seu uso enquanto definição do próprio Campo, isto é, o Campo do Design definido a partir de seu modus operandi, fato que traz inúmeras indagações teóricopráticas. Ver: HEINRICH, Fabiana Oliveira. Design: crítica à noção de metodologia de projeto. Dissertação de Mestrado. Orientador: Alberto Cipiniuk. Pontifícia Universidade Católica do Rio de Janeiro, Departamento de Artes e Design, 2013.
} 
experimentais do desenvolvimento do pensamento e do trabalho. Neste sentido, considerar a experiência como algo adquirido, algo que nos transforma, deixandonos diferente de como estávamos/éramos quando começamos a tarefa, é passível de ser corroborado somente ao fim. Assim como só é possível corroborar ao fim o entendimento, a recepção de um estudo por parte do leitor - afinal, produzimos textos para serem lidos - através da sua experiência de leitura. Vamos a ela. 
2.

\section{DA EXPERIÊNCIA}

Principiamos este estudo pela definição do que é considerado contemporaneamente experiência no Campo do Design, e por uma posterior ampliação de seu significado no pensamento humano, tendo em vista que consideramos a conceituação do Campo equivocada. Os motivos ficarão claros a seguir.

\section{1.}

\section{Design de Experiência: vertente teórica humanista ou orientada pelo mercado?}

Por mais que seja recorrente a invocação de universais no entendimento de um conceito, este é sempre condicionado historicamente, isto é, sua definição e uso ocorrem em determinado tempo-espaço, de acordo com as relações sociais de produção vigentes e são por estes determinados. Deste modo, é possível reportar a gênese do uso contemporâneo do termo experiência no Campo do Design a duas distintas vertentes, as quais identificamos a partir do questionamento de Erdem Demir (2008, p. 141)1: "ideais de Design e emoção — realmente humanistas, ou orientados pelo mercado?" O autor não emprega essa separação para necessariamente tratar da gênese da relação entre Design e emoção — nem da noção de Design de Experiência propriamente dita, não obstante esse termo esteja dentre suas preocupações - mas sim para compreender seu uso ou "verdadeiro" sentido nos dias de hoje. Nós a empregamos para tentar entender a gênese da noção de Design de Experiência, uma vez que entender seu uso - ou valor de uso - hoje requer um entendimento histórico. A vertente talvez erroneamente chamada

\footnotetext{
${ }^{1}$ DEMIR, Erdem. The field of design and emotion: concepts, arguments, tools, and current issues. In.: Journal of the Faculty of Architecture (METU JFA), no. 25(1), 2008.
} 
"humanista"2 tem nos estudos da Interação Humano-Computador (IHC) da década de 1970 - que postulam se preocupar, sobretudo, com o usuário ${ }^{3}$ — a sua origem, enquanto que a vertente orientada pelo mercado tem na noção de Economia da Experiência, cunhada em 1998, seu início. Essas duas noções não necessariamente se contradizem, por vezes até mesmo se complementam, como quando a primeira é tomada como base teórica e ético-ideológica para a segunda, como veremos no subcapítulo 2.1.3. O que é, afinal, Design de Experiência? Entretanto, julgamos fazer sentido abordá-las separadamente aqui, com vias de esclarecimento intelectual e organização teórica.

Contudo, isto não quer dizer que o termo experiência nunca tenha sido empregado no Campo ${ }^{4}$ antes: usamos o adjetivo contemporâneo em uma sentença do parágrafo anterior justamente para evidenciar que este uso não é novo, salvo seu entendimento de experiência como mercadoria no Campo do Design. Experiência com o produto e, principalmente, experiência estética, já eram termos recorrentes, entretanto apenas como meios de explicação para qualidades e características tanto formais - mas sobretudo subjetivas - que despertavam sentimentos e "desejos" pelos produtos. ${ }^{5}$ Como nosso ponto aqui é compreender a experiência como mercadoria - ou melhor, se ela pode ser uma mercadoria — , faz-se necessário identificar em que momento ela deixa de ser apenas uma qualidade, uma

\footnotetext{
${ }^{2}$ Como veremos a seguir, talvez o termo "tecnológica" se encaixe melhor, uma vez que as iniciativas ditas humanistas - que se preocupam com o usuário — são sobretudo tecnologicamente determinadas.

${ }^{3}$ Devemos salientar que o leitor irá se deparar com distintos termos para o que poderíamos considerar uno: cliente, consumidor, indivíduo, pessoa, sujeito, usuário. Optamos aqui por utilizar os termos conforme eles são empregados nos textos, e não adotar apenas um, pois essa adoção plural diz muito sobre a localização desse problema no contexto do Campo e sobre o teor do texto abordado, bem como constitui arsenal para nossa discussão crítica no Capítulo 4 - Crítica da experiência como mercadoria no Campo do Design.
}

${ }^{4} \mathrm{O}$ termo Campo, aqui, é um termo técnico, tal como Pierre Bourdieu o definiu, e não um espaço geográfico onde os profissionais trabalham ou a sua dimensão imaginada ou topológica. Para uma definição de Campo, ver: "A gênese dos conceitos de habitus e de campo". In.: BOURDIEU, Pierre. O poder simbólico. Rio de Janeiro: Bertrand Brasil, 2003. Ver também: "O mercado de bens simbólicos”. In.: BOURDIEU, Pierre. A economia das trocas simbólicas. São Paulo: Perspectiva, 2001.

${ }^{5}$ Adrian Forty investigou, já em 1986, o modo de operação de objetos projetados para despertarem desejos. Ver: FORTY, Adrian. Objetos de Desejo: Design e Sociedade desde 1750. São Paulo: Cosac Naify, 2007. Também Eric Anderson discorre sobre a experiência de espaços e objetos a partir de teorias da cor, visão e subjetividade. ANDERSON, Eric. Hans Makart's Technicolor Dream House: Decoration and Subjectivity in Nineteenth-Century Vienna. In.: West 86th: A Journal of Decorative Arts, Design History, and Material Culture, no. 22(1). Spring-Summer, 2015. 
característica ou o resultado de um uso e passa a ser, talvez equivocadamente, um produto $^{6}$ em si mesmo, ou melhor, em que momento essa qualidade ou esse resultado de uso são vistos como raison d'être do produto. Atentamos que, ao considerar a experiência como um produto, isto não necessariamente quer dizer que ela terá formato físico ou alguma materialidade, mas sim que a sua forma de realização no Campo do Design é concreta e se dá como a realização da maior parte dos produtos desenvolvidos no Campo, ou seja, como uma mercadoria. Mas será que isso que chamamos de experiência, ou que projetamos como uma, é mesmo uma experiência, e será que ela pode ser uma mercadoria?

Sendo assim, a seguir abordaremos ambas as vertentes, não obstante consideremos que a vertente orientada pelo mercado, que tem a noção de Economia da Experiência como sua base, traga a questão da mercadoria mais à frente, visto que praticamente quase todo texto que, desde 2000 até hoje (2018), trate de Design de experiência cite e reporte o texto Welcome to the Experience Economy ${ }^{7}$ como base inicial para suas definições conceituais. O corpus teórico relativo à noção de Design de Experiência (Experience Design), foi definido a partir de busca na base de dados de artigos acadêmicos Google Scholar, na base de dados do sistema de bibliotecas da PUC-Rio e da Fleet Library (RISD), com o uso do termo Experience Design no título ou nas palavras-chave. Ainda, com o intuito de realizar uma genealogia cronológica do termo, utilizamos junto às palavras buscadas os anos de 2000 a 2017 (como “Experience Design 2000”), para visualizarmos o desenvolvimento e as mudanças na sua conceituação. Termos correlatos, como Design for Experience, User Experience Design, UX, Experience-centered Design, Experience-based Design, não constituíram palavras-chave na busca, mas acabaram sendo indiretamente abordados, uma vez que suas definições são muito próximas e, por vezes, aparecem até mesmo como sinônimos para Experience Design.

\footnotetext{
${ }^{6}$ No Capítulo 3 - Da mercadoria, mais precisamente em 3.2.4 - Mercadorias ou produtos? A querela no Campo do Design, abordaremos a distinção existente entre o emprego das noções de mercadoria e produto e, sobretudo, as consequências ideológicas deste emprego para o Campo do Design. Neste momento, é suficiente apenas apontarmos que existe uma contradição.

${ }^{7}$ PINE, B. Joseph. II; GILMORE, James. H. Welcome to the Experience Economy. In.: Harvard Business Review, July-August, 1998.
} 
Assim, a seguir, apresentamos e discutimos as definições do conceito de Design de Experiência, bem como as premissas que fundamentaram essas definições, com vistas a um esclarecimento e entendimento de seu emprego e contemporânea relevância no Campo do Design.

\subsection{1.}

\section{Vertente teórica humanista}

Design de Experiência (Experience Design), Design para Experiência (Design for Experience), Design da Experiência do Usuário (User Experience Design), UX, Design centrado na Experiência (Experience-centered Design), Design baseado na experiência (Experience-based Design): todos esses termos surgiram e ganharam aceitação nos estudos de Interação Humano-Computador (IHC) e Design de Interação recentemente. Esse interesse em experiência está associado a desenvolvimentos tecnológicos como mobiles e wearables $^{8}$, ambientes virtuais, Web $2.0^{9}$ e a confluência de tecnologias de informação e comunicação, informática, mídia e entretenimento, configurando o nosso mundo como algo fragmentado e evanescente. Esses desenvolvimentos tecnológicos mostram a amplitude e a profundidade das mudanças sócio-técnicas que vivemos, as quais levaram o Campo do Design a enfatizar o conhecimento acerca do usuário e a compreensão da sua experiência como fundamentação e justificativa para a atividade de projetar. Mas o que sustentou e como ocorreram essas mudanças no Campo do Design?

Conforme Manuela Quaresma (2018, p. 89) ${ }^{10}$, a noção de experiência do usuário é oriunda dos estudos de Interação Humano-Computador (IHC), que começou a ser tratada como área do conhecimento por volta da década de 1970, tendo suas origens na Ergonomia/Fatores Humanos, na Psicologia Cognitiva, no

\footnotetext{
${ }^{8}$ Mobile refere-se a dispositivos tecnológicos móveis, enquanto wearable refere-se a dispositivos tecnológicos que podem ser utilizados pelos usuários como peças do vestuário, chamados de "tecnologias vestíveis", como óculos e relógios, geralmente denominados smart — objetos inteligentes.

${ }^{9}$ Web 2.0, termo utilizado a partir de 2004, refere-se a uma segunda geração de comunidades e serviços online, tendo como conceito a "Web como plataforma", envolvendo wikis — páginas interligadas e editáveis - , aplicativos, redes sociais, blogs e tecnologia da informação.

${ }^{10}$ QUARESMA, Manuela. UX Designer: quem é este profissional e qual é a sua formação e competências? In.: Design para acessibilidade e inclusão. São Paulo: Blucher, 2018.
} 
Design e na Ciência da Computação. Questões relacionadas à interação com hardware $^{11}$ — treinamento, documentação, editores de texto — foram as primeiras preocupações, ao passo que a interação com softwares ${ }^{12}$ passou a ser o foco em um segundo momento. Durante a década de 1980, com o surgimento dos computadores pessoais e a influência da Psicologia Cognitiva, considerou-se o surgimento do que hoje é entendido como usabilidade, a qual consiste na compreensão do comportamento e desempenho humano na interação analisados em si mesmos, isto é, o desempenho humano fora do seu contexto histórico concreto, mas atentando à cognição, memória, percepção, atenção e tomada de decisão, sem considerar uma finalidade teleológica específica. A cognição não é pensada para isso ou aquilo, mas idealisticamente, enquanto algo que se encerra nas suas próprias operações internas.

Assim, antes de avançarmos, gostaríamos de ponderar que esse tipo de análise é parcial e diz respeito a uma discussão filosófica descolada do mundo material onde ela ocorre concretamente. Prosseguimos.

Os três componentes da usabilidade são eficácia, eficiência e satisfação os dois primeiros medidos de forma objetiva e o terceiro de forma subjetiva decorrente dos anteriores. De acordo com a autora, no final da década de 1990, início de 2000, novos componentes da interação, como prazer, emoção, afetividade e encantamento, começaram a ser considerados pontos de estudo, uma vez que a medida de satisfação da usabilidade é limitada somente ao resultado satisfatório da relação eficácia e eficiência do sistema, não considerando questões mais subjetivas do usuário. Neste sentido, Patrick W. Jordan $(2002)^{13}$ postula o que ele chama de Nova Ergonomia, ou Novos Fatores Humanos, enfatizando que as pessoas querem também prazer na interação, e não apenas usabilidade. Assim, Quaresma (2018, p. 90) afirma que se torna necessário motivar o usuário a "comprar" (termo da autora) a ideia de interação e uso do produto, encantando e proporcionando uma excelente experiência ao longo do uso, além de ser necessário também mantê-lo utilizando o produto pelo máximo de tempo possível. Esses fatores seriam os responsáveis, do

\footnotetext{
${ }^{11}$ Hardware refere-se às partes ou componentes físicos de um computador, como monitor e teclado.

${ }^{12}$ Software refere-se aos programas que são armazenados e utilizados nos computadores.

13 JORDAN, Patrick. W. Designing pleasurable products: an introduction to the new human factors. CRC Press Taylor \& Francis, 2002.
} 
ponto de vista da IHC, pelo conceito de User Experience (UX ou Experiência do Usuário). Entretanto, para Quaresma (2018, p. 90), boa parte dessa experiência ainda é resultado de um "bom projeto", que segue à risca os preceitos da usabilidade. Segundo a autora, o termo teria sido primeiramente utilizado por Donald Norman (2013) ${ }^{14}$ quando este trabalhava para a Apple, no início dos anos 1990, e denominou seu grupo de trabalho como "the user experience Architect's office". Ela afirma que Norman pensava em uma definição ampla da noção de experiência, que abrangia toda uma experiência que uma pessoa poderia ter ao interagir como um produto qualquer - e não necessariamente apenas uma interação ou experiência digital.

Em consonância, Lim Y. et al (2008) ${ }^{15}$ afirmam que, à medida que se avança na direção de uma maior ênfase na experiência e nas emoções, pesquisadores e profissionais da IHC começam a redefinir o significado de Design centrado no Usuário - de uma ênfase na eficiência e na usabilidade para um contexto holístico mais amplo do comportamento humano. Esta direção deveria promover a compreensão da interação homem-computador como composta por significados, experiências e valores relevantes para contextos pessoais ou culturais, o que levaria os pesquisadores a explorar a natureza da experiência humana que emerge em interações com tecnologias. Nesta mesma linha, em escrito anterior e citado por Lim Y. et al (2008, p. 5), John McCarthy e Peter Wright (2004, p. 43) ${ }^{16}$ propõem a noção de Tecnologia como Experiência (Technology as Experience, título do livro), através da qual a experiência do usuário teria se tornando quase como uma nova forma de usabilidade, uma nova orientação para o entendimento da experiência em IHC. Os autores sugerem que trabalhar com a tecnologia como experiência pode fornecer as bases apropriadas para essa nova orientação, através de uma visão singular e de irredutibilidade da experiência a partir do objeto tecnológico. Eles argumentam que, embora possamos concentrar nossa análise em certos aspectos como a estrutura espaço-temporal de uma experiência — - devemos ter o cuidado

\footnotetext{
${ }^{14}$ NORMAN, Donald. A. The design of everyday things. Basic Books, 2013.

${ }^{15}$ LIM Y. et al. Emotional Experience and Interaction Design. In.: Affect and Emotion in HumanComputer Interaction. Lecture Notes in Computer Science, vol 4868. Springer, Berlin, Heidelberg, 2008.
}

${ }^{16}$ MCCARTHY, John; WRIGHT, Peter. Technology as Experience. MIT Press, 2004. 
de não reduzir a experiência a somente isso. Deste modo, eles defendem instâncias singulares de experiências através da interação única com o objeto tecnológico, em vez de modelar classes de experiências, evitando assim tentativas de compreender a experiência como redutível, previsível ou explicável por seus processos e elementos subjacentes. Complementam, ainda, que emoções são construções culturais, diferentes e irredutíveis aos processos fisiológicos anteriormente exaltados pela linha da IHC. Esta visão de McCarthy e Wright deve muito à noção de experiência de John Dewey, pragmatista norte-americano, que abordaremos mais à frente.

Em um aprofundamento dos estudos e considerações acerca da noção de experiência no Campo do Design, em outra publicação McCarthy e Wright (2010, p. $22-23)^{17}$ ponderam que, por uma vertente humanista, o conceito de experiência do usuário deve incluir, além do usuário, o produto e o contexto de uso, tendo em vista que a experiência vivenciada pelo usuário não ocorre somente a partir dele. Assim, produtos e ambientes transformam-se em contextos das experiências e devem ser considerados no projeto a ser desenvolvido. Com efeito, eles consideram como os principais pontos de referência nesta nova visão do humano no IHC: i) valorizar toda a pessoa por trás do "usuário"; ii) focar em como as pessoas fazem sentido de suas experiências; iii) ver o designer e o usuário como coprodutores de experiência; iv) ver a pessoa como parte de uma rede de relacionamentos sociais através dos quais a experiência é co-construída; e v) considerar a pessoa como agente interessado, imaginando possibilidades, fazendo escolhas criativas e atuando. É curioso observar aqui o câmbio entre os termos "pessoa" e "usuário", no que parece ser uma tentativa dos autores de "humanizar" o usuário projetado pelo Campo do Design, ao utilizar um termo que, em seu ponto de vista, deve ser entendido com mais abrangente e holístico. Contudo, mesmo assim, silencia-se o fato de que estamos em uma sociedade industrial, movida pelo modo de produção capitalista - trata-se de uma humanização ideal ou absoluta, mais ou menos como desejar colocar no mesmo escaninho teórico a classe média brasileira e a classe média de Oslo.

\footnotetext{
${ }^{17}$ MCCARTHY, John; WRIGHT, Peter. Experience-centered design: designers, users, and communities in dialogue. Morgan \& Claypool, 2010.
} 
Já Katja Battarbee e Ilpo Koskinen $\left(2005\right.$, p. 7) ${ }^{18}$ consideram que o surgimento do termo experiência na literatura do Campo do Design pode ser conectado em parte a uma certa "decepção" com a usabilidade, e não necessariamente uma "evolução" desta — ou talvez uma evolução justamente pela sua limitação. A usabilidade foi vista como o facilitador da utilidade e, uma vez que ela não aborda as qualidades mais fugazes de interação com produtos, como estética, associações, emoções, desafios e muitos aspectos relevantes da experiência humana, os autores consideram que a pesquisa teve de mover-se para além dessas áreas. Eles afirmam que quando gostos, valores, expectativas e outras possíveis fontes de prazer são conhecidos, estes podem ser utilizados no projeto de Design através de formas, imagens e outras qualidades, considerando o movimento além da usabilidade como uma abordagem para olhar além da funcionalidade e suas qualidades objetivas e mensuráveis.

Por sua vez, Marc Hassenzahl e Noam Tractinsky (2011, p. 91-93) $)^{19}$ concordam que profissionais e pesquisadores parecem prontamente adotar a noção de $U X$ como uma alternativa viável ao IHC tradicional, porém criticam a noção por ser essa, ao mesmo tempo, repetidamente vaga, evasiva e efêmera. Eles discorrem que não obstante a atenção à importância das emoções seja um lado positivo, esta é vista por uma perspectiva do computador, pois trata predominantemente de questões como a forma como os computadores podem sentir o impacto do utilizador, adaptar-se a ele ou mesmo expressar a sua própria resposta afetiva e não necessariamente o ponto de vista do usuário sobre a máquina e/ou o sistema. Assim, eles consideram que os estudos em $U X$ devem assumir uma perspectiva "humana", pois estão interessados em entender o papel da emoção como um antecedente, uma consequência e um mediador do uso da tecnologia. Com efeito, eles afirmam que evitar a frustração e a insatisfação foi sempre um objetivo central dos estudos de IHC e, portanto, o que seria novo na pesquisa de $U X$ agora é um foco em resultados emocionais positivos.

Em continuidade, Hassenzahl e Tractinsky (2006, p. 94-95) ainda consideram que, de um modo geral, existem duas formas básicas de lidar com as

${ }^{18}$ BATTARBEE, Katja; KOSKINEN, Ilpo. Co-experience: user experience as interaction. In.: CoDesign, Vol. 1, No. 1, March 2005.

19 HASSENZAHL, Marc; TRACTINSKY, Noam. User experience - a research agenda. In: Behaviour \& Information Technology, Vol. 25, No. 2, March-April 2006. 
emoções em $U X$ : uma linha que enfatiza a importância das emoções como consequências do uso do produto e outra que se concentra na sua importância como antecedente do uso do produto e como julgamentos avaliativos. Ainda, os autores afirmam que $U X$ é sobre uma tecnologia que atende mais do que apenas necessidades instrumentais: é uma forma que reconhece seu uso como um encontro subjetivo, situado, complexo e dinâmico. Assim, $U X$ seria uma consequência do estado interno de um usuário — predisposições, expectativas, necessidades, motivação, humor etc. - , das características do sistema projetado - por exemplo, complexidade, propósito, facilidade de uso, funcionalidade etc. - e do contexto ou ambiente no qual a interação ocorre - por exemplo, configuração organizacional, social, significado da atividade, voluntariedade de uso etc. Com efeito, os autores consideram que o foco em aspectos além do funcional, positivo, experiencial e emocional deveria ser de interesse para vendedores comerciais, sensíveis às mudanças no "clima" de negócios, designers, que apreciam novas oportunidades de Design, e pela comunidade científica em geral, que mostra interesse renovado no sistema afetivo e sua interação com a cognição.

Entretanto, há críticas e ressalvas a esses entendimentos. Os próprios McCarthy e Wright (2010, p. 79), por exemplo, afirmam que, não obstante os estudos de IHC e suas aplicações tenham surgido no âmbito da Ergonomia - esta oriunda do pós-guerra na década de 1950, quando a busca por tornar a tecnologia mais segura, acessível e utilizável pelas pessoas era o norte — não podemos considerar que exista um bem inerente a nenhuma tecnologia: o que ditará sua benevolência é o seu uso. Neste sentido, os autores consideram que a dita revolução digital que começou na década de 1970, que ainda está em andamento e que tem transformado fundamentalmente nossas experiências e nossos modos de vida em distintas áreas, do trabalho ao lazer, pode tanto capacitar as pessoas como desumanizá-las. Para exemplificar, eles apontam serviços de informação que acabam por transformar os usuários em uma série de caracteres, forçados a submeterem-se a ações que podem ser inteligíveis apenas pelos algoritmos de atendedores automáticos de serviços web. Além disso, apontam que o modus operandi de conversas naturais é parodiado pelo chamado software de reconhecimento de voz e isso leva os usuários a gritar em linhas telefônicas como se estivessem tentando argumentar com um cão demente. Também apontam que os usuários gastam horas de suas vidas navegando em diálogos pré-programados 
labirínticos, enquanto esperam para serem conectados para obter uma informação simples que um ser humano poderia ter fornecido em um segundo ou dois. Contudo, McCarthy e Wright (2010, p. 80) também consideram que, para além de toda essa desumanização, a tecnologia digital pode ser uma fonte de capacitação, criando um ambiente que permita às pessoas ter maior controle de suas vidas, aumentar a sua ligação social e melhorar a qualidade de sua experiência vivida, permitindo que se tornem aquilo que querem ser. Logo, os autores consideram que a agenda do Design centrado na Experiência pode - e deve - consistir da "humanização da tecnologia digital, de modo que ela possibilite às pessoas, através de sua poesia e política, desfrutarem e exercerem controle sobre si próprias como membros de um coletivo chamado humanidade.” (MCCARTHY e WRIGHT, 2010, p. 81)

Em consonância crítica, Johan Redström (2006, p. 123-124) ${ }^{20}$ afirma que a intenção de conceber a experiência do usuário parece apontar para uma situação em que se tenta otimizar o ajuste entre sujeito e objeto no Campo do Design com base em previsões ao invés de conhecimento, eventualmente tentando projetar algo que não é para ser projetado. $\mathrm{O}$ autor postula que particularmente acerca de aparelhos eletrônicos, sistemas interativos e coisas computacionais, tem havido um aumento no interesse pelo Design de experiência e na concepção da experiência do usuário, posto que projetar experiências pode ser visto tanto como um esforço para expandir o espaço do Campo do Design, uma parte de um desenvolvimento do discurso "além do objeto" (THACKARA, 1988) 21; como uma resposta às deficiências dos modelos existentes de entendimento do uso e dos usuários nos processos de Design. $\mathrm{O}$ autor afirma ainda que o crescente interesse pelos usuários e suas experiências deve também ser entendido à luz dos projetos que não conseguem aprovação por esses mesmos usuários e situações em que o uso pretendido destes projetos não se traduz em uso real. Assim, Redström (2006, p. 123-124) considera que se tenta no âmbito do Design centrado no Usuário - ultrapassar o conhecimento insuficiente sobre pessoas, suas capacidades, necessidades e desejos com uma variedade de métodos para estudar usuários, testar protótipos e envolver potenciais

\footnotetext{
${ }^{20}$ REDSTRÖM, Johan. Towards user design? On the shift from object to user as the subject of design. In.: Design studies, 27(2), 2006.

${ }^{21}$ THACKARA, John (ed). Design after modernism: beyond the object. Thames and Hudson, New York, USA, 1988.
} 
usuários no processo de Design. Ainda, ele considera que esse interesse em experiências configura uma resposta às ideias estabelecidas sobre usabilidade e utilidade, as quais o autor considera excessivamente restritas, conforme já vimos com McCarthy e Wright (2004 e 2010) e Hassenzahl e Tractinsky (2006).

Contudo, Redström (2006, p. 124-125) vai um pouco mais longe, a um período anterior à Ergonomia, para traçar as bases do que teria dado origem a essa preocupação com o usuário no Campo do Design. O autor postula que os movimentos modernistas são a origem dessa preocupação, uma vez que com as ambições sociais destes, o Campo do Design teria tornado-se cada vez mais interessado no projeto de "uso" de objetos, sua função, em detrimento do que era antes apenas uma preocupação com a forma, decoração ou com o projeto de objetos de pouca relevância para as necessidades sociais. O autor afirma que com o Modernismo, a prática do Campo do Design tornou-se não só uma questão de projetar objetos como tal, mas cada vez mais uma questão de como as formas de uso e até as formas de vida podem ser projetadas e que, portanto, poder-se-ia considerar que há algo como uma agenda social para o Design, a qual almejaria uma transformação social. Essa agenda poderia ser vista hoje, então, com suas devidas atualizações, nas preocupações do Design de Experiência.

Em um segundo momento, Redström (2006, p. 125-126) defende que, após a preocupação com a função em detrimento da forma, passamos para a preocupação da comunicação sobre a função, pois a nova direção para projetar o uso também significou que a noção de usuários, suas reações e experiências entraram em jogo. Não obstante ponderando que os aspectos sociais do projeto modernista podem ter sido ambiciosos, o autor postula que eles não conseguiram necessariamente alcançar o desejado, pois há uma série de exemplos de desajustes entre o uso pretendido e o uso real, entre a concepção e a compreensão do objeto do usuário. Com efeito, estando a prática do Design mais próxima de projetar o uso dos objetos — ou deveriam ser objetos com valor de uso? - , torna-se relevante considerar como um determinado projeto convida potenciais usuários a interpretar a sua forma e em que medida e de que maneira este processo é algo que os designers podem controlar. Uma das frentes que trabalham com essa configuração do Campo do Design é talvez a Semiótica, que considera o Design como um sistema de comunicação de signos, buscando torná-lo fácil de entender e interpretar. Contudo, os projetos de Design tornam-se então uma questão de usar o "idioma" certo para 
expressar a funcionalidade e o uso pretendido do objeto, tentando moldar a percepção dos objetos por parte dos usuários - , entretanto, sabemos que essa frente teórica também não se realiza em sua totalidade, não alcança aquilo que promete, uma vez que entendimentos são circunstanciais, culturais, e que mesmo a chamada "Linguagem" Visual não é tão universal em si quanto postulado, mas talvez somente através de sua inculcação, que é arbitrária.

Assim, Redström (2006, p. 126-127) considera que o movimento em direção ao usuário - passando pela forma, o uso e a comunicação — tem ligação com novas preocupações projetuais, como as necessidades, desejos e experiências deste usuário. Neste sentido, parece ser uma conclusão lógica que um conhecimento mais extenso e uma melhor compreensão ou definição disso que é o usuário faz-se necessária para que os designers desenvolvam melhores soluções. Logo, considerando o Design de Interação como sendo "sobre a criação de experiências de usuários que aprimoram e ampliam a forma como as pessoas trabalham, se comunicam e interagem”, Redström (2006, p. 127) argumenta que esse movimento é mais do que apenas uma questão de como projetar para o usuário a partir de uma identificação de suas necessidades e do entendimento dessas, projetando sistemas utilizáveis e agradáveis: este movimento indica, antes de mais nada, uma mudança sobre o que o Design é, uma mudança ontológica. Com efeito, o autor afirma que se o Design costumava ser uma questão de forma física - seu objeto era o objeto material - agora parece ser sobre o usuário e suas experiências, e podemos considerar então que o usuário vira o objeto do Campo do Design. Entretanto, o que significa dizer que o objeto do Design é a "experiência do usuário"? Redström (2006, p. 127) afirma que esta questão é bastante diferente da preocupação acerca de informações e conhecimentos que pensamos serem necessários no processo de Design e como escolhemos obter isso: esta é uma questão sobre o que pensamos que estamos criando. Logo, a ideia de que estaríamos "projetando o usuário" - ou mais necessariamente, o consumidor -, e não necessariamente "para o usuário", é a discussão em jogo.

Em continuidade, Redström (2006, p. 127-128) coloca que a ideia de que os projetos de Design podem ser otimizados com base no conhecimento sobre usuários passou a considerar a possibilidade de "adaptação" ou "ajuste" do usuário não só em termos de utilidade ou usabilidade, mas também no que diz respeito à interpretação, compreensão e experiência. Consequentemente, criar essa adaptação, 
ou esse "ajuste" entre pessoas e objetos projetados propicia a possibilidade — ou, adicionamos nós, necessidade — de fazer com que as pessoas se encaixem em sistemas, sociedades e estratégias. Entretanto, o autor considera que não podemos simplesmente impor objetos aos usuários: as pessoas são partes ativas do sistema, e porque são muito menos previsíveis e menos compreendidas do que os computadores e outras partes tecnológicas desse sistema, elas exigem um estudo e compreensão ainda maiores. Assim, Redström (2006, p.128-129) afirma que os problemas de projetos que falharam nos testes de uso geraram um conjunto de ideias relacionadas ao papel do usuário em Design, colocando-o em destaque em distintas frentes. A primeira parte do princípio de que esses problemas podem ser evitados através da otimização do ajuste entre o objeto e o usuário, e a segunda, de que o Design pode, ou mesmo precisa, ser projetado com base no conhecimento sobre usuários, suas capacidades, habilidades e desejos.

$\mathrm{O}$ autor considera que existem, no entanto, razões para questionar esse desenvolvimento, o qual resulta em uma confusão entre o que estamos projetando e quem vai usá-lo. A primeira razão pela qual isso se torna problemático seria o ajuste otimizado com base no conhecimento sobre uso e usuários, pois ajustar significa caber, adaptar, em detrimento de outra coisa. Uma segunda razão seria que otimizar o ajuste exige que saibamos, em detalhes, as relações que estamos fazendo. Com efeito, se não sabemos, ou seja, se essas relações não são claras, reduzimos sistematicamente o espaço do usuário para interpretações alternativas e maneiras de usar nosso projeto com base, talvez, nos motivos errados. Logo, conforme Redström (2006, p. 129), não podemos confiar no conhecimento sobre uso e usuários desta maneira, sobretudo pelo simples fato de que não pode haver usuários de coisas que não existem - e então o foco volta ao objeto - neste caso o objeto tecnológico, interativo.

Por fim, um último ponto a se considerar sobre a vertente teórica humanista da origem do Design de experiência é a noção de Design Participativo. Segundo McCarthy e Wright (2010, p. 7), a prática e a história do Design Participativo têm uma trajetória de desenvolvimento diferente daquela do Design centrado no Usuário, mas tiveram seu início aproximadamente na mesma época e compartilham em grande parte da mesma visão. Considerando que o Design centrado no Usuário consistiu principalmente de uma resposta aos estudos cognitivos e à necessidade de desenvolver melhores sistemas informáticos, o desenvolvimento do Design 
Participativo deve grande parte de sua relevância aos embates e energias morais, políticas e comunitárias da sociedade escandinava democrata.

Conforme os autores, o Design Participativo surgiu na Escandinávia como uma resposta à automação em escala industrial e à informatização de processos de negócios previamente manuais, em indústrias como a da metalurgia e da impressão. $\mathrm{Na}$ Escandinávia, com a sua longa tradição de sindicalismo e socialdemocracia, as possibilidades de democratização do processo de informatização envolvendo trabalhadores e sindicatos diretamente no processo de Design foram exploradas em vários projetos na década de 1970. McCarthy e Wright (2010, p. 7) consideram que esses projetos se afastaram do modelo de pesquisa tradicional para um em que pesquisadores e trabalhadores colaboraram conjuntamente para produzir melhores condições de trabalho, através de consulta ativa e contínua entre designers, desenvolvedores, gerentes e trabalhadores. Esta abordagem de pesquisa enfatizou a própria experiência dos trabalhadores no desenvolvimento de recursos para ajudálos a atuar nas situações que se apresentavam, bem como exigiu que os pesquisadores se envolvessem com os trabalhadores e desenvolvessem um compromisso conjunto, a fim de compreender e ajudar a mudar suas experiências e condições de trabalho.

McCarthy e Wright (2010, p. 7) afirmam que nos primeiros projetos de Design Participativo, a ideia de que as organizações são unitárias ou harmoniosas foi rejeitada, em favor de uma visão das organizações como conflituosas. Assim, seriam necessários mecanismos para lidar com esses conflitos inerentes diariamente, sobretudo através de saídas tecnológicas que considerassem as experiências dos trabalhadores no desenvolvimento de sistemas tecnológicos, e alternativas às organizações de trabalho. Contra este pano de fundo, a busca pela melhora no uso e na experiência da informatização dos trabalhadores tornou-se mister, e os autores identificam aqui uma atitude com fundo político. McCarthy e Wright (2010, p. 7) consideram, ainda, que há também uma tradição americana de Design Participativo, surgida na década de 1990 e que tomou uma abordagem semelhante, porém relativa à diferente participação de stakeholders na tomada de decisões de projetos e processos de Design, para garantir não só informações úteis e sistemas utilizáveis, mas também uma "compra justa" de distintas partes interessadas em toda a divisão política. Temos aqui, então, uma aproximação com a esfera econômica que subjaz o Campo do Design. Além disso, podemos sinalizar 
que frentes como o método de Design Thinking ${ }^{22}$, sobretudo a partir dos projetos e da metodologia da $I D E O^{23}$, apresentam fundamentação no Design Participativo.

Com efeito, McCarthy e Wright (2010, p. 8) consideram que, embora muitas vezes estejam presentes, esses ideais éticos e políticos raramente são articulados dentro da comunidade de pesquisa HCI, pois suas implicações nem sempre são totalmente compreendidas. Um exemplo: projetos de Design centrado no Usuário muitas vezes são desenvolvidos para o atendimento de objetivos de negócios de curto prazo, como reduzir ineficiências e/ou custos e melhorar a produtividade, tornando o trabalhador mais rápido e menos propenso a erros. Os autores consideram que estas não são frentes ruins em si mesmas, sendo por vezes benéficas tanto para o trabalhador quanto para o empregador, mas geralmente elas negligenciam a capacidade, a contribuição e as preocupações dos trabalhadores envolvidos. Mesmo com os novos conceitos de Design centrado na Experiência, o impulso e a agenda humanista podem ser sequestrados para atender unicamente à identidade de uma marca e à atratividade do produto, em vez de melhorar a vida das pessoas que compram os produtos. Logo, McCarthy e Wright (2010, p. 9) postulam que o Design centrado na Experiência não deve se tornar exclusivamente uma estratégia de negócios ou, pior, um mantra empresarial que nunca amadurece: ele pode - e deve - tentar impactar a experiência vivida das pessoas de forma social, política e pessoal, sobretudo com pesquisas e projetos sobre tecnologias para ação social, saúde, patrimônio e espiritualidade, no contexto de instituições, práticas, modos de pensamento e discurso, política e democracia. ${ }^{24}$

Entretanto, quais são os limites entre o discurso das iniciativas humanistas e a realidade da prática econômica subjacente? Da própria análise recém traçada dos escritos sobre a vertente, podemos observar que talvez até mesmo o termo

\footnotetext{
${ }^{22}$ A metodologia do Design Thinking se diferencia das outras por não ter um modelo esquemático, etapas específicas e desdobradas, nem uma sequência de entrada e saída de informações, mas sim fases que são tarefas a serem realizadas, em que prevalecem diretrizes do mercado. Foi desenvolvida pela empresa IDEO - ver nota 21.

${ }^{23}$ Empresa norte-americana de Design e consultoria em inovação, fundada em 1991, que trabalha com metodologia própria, o Design Thinking. Há ainda um desdobramento desta, a metodologia com ênfase em Human-Centered Design. Eles disponibilizam o HCD Toolkit, um conjunto de materiais através dos quais explicam a estrutura desta metodologia, além de cursos online que ensinam a aplicá-la, sobretudo a projetos de cunho "humanístico". Ver: www.ideo.com. Acesso em 9 de março de 2018.

${ }^{24}$ Devemos apontar aqui a proximidade deste pensamento da linha de John Dewey, que será abordada em breve.
} 
humanista tenha que ser revisto, pois é um determinismo tecnológico que impera. Neste sentido, talvez devêssemos nomeá-la vertente tecnológica? Ou quais seriam as implicações de chamá-la de um humanismo tecnológico — é possível concebermos este termo? Discutiremos outros entendimentos acerca da relação entre ciência, indústria e tecnologia e uma visão humanista na segunda parte deste capítulo. Por ora, devemos nos concentrar na vertente mercadológica da noção de Design de Experiência, pois, pode o enfoque dos estudos acerca da emoção e da subjetividade do usuário, conforme apresentados, realmente ultrapassar os interesses econômicos e políticos?

\subsection{2.}

\section{Vertente orientada pelo mercado}

Joseph Pine conta que era final de 1993, talvez início de 1994, quando ele concebeu a ideia do que viria a definir em publicação em $1998^{25}$, junto de James Gilmore, como Economia da Experiência (Experience Economy). Pine ministrava uma aula para funcionários da IBM Consulting Group no IBM Advanced Business Institute em Palisades, Nova Iorque, explicando como a customização em massa - que ele define como a produção individual de um produto físico personalizado com baixos custos e operações eficientes - automaticamente transforma o produto, em sua concepção, em um serviço. Ainda, ele indicava como os economistas utilizam distinções clássicas para diferenciar bens de serviços: enquanto bens são padronizados, serviços são personalizados, feitos em nome de um cliente individual; enquanto bens são inventariados após a produção, serviços são entregues sob demanda, como quando o cliente diz que isso é exatamente o que ele quer; e enquanto bens são tangíveis, serviços são intangíveis. Segundo o autor, parte deste processo de customização em massa teria a finalidade de ajudar os clientes a descobrir exatamente o que eles desejam. Durante essa aula, Pine (2012, p. 22-23) conta que um dos consultores da $I B M$ questionou: "Você fala também de customização em massa de serviços. O que seria, então, um serviço customizado?",

\footnotetext{
${ }^{25}$ Ver referência na nota 6. Este texto de 1998 foi transformado em livro em 1999: PINE, B. Joseph. II; GILMORE, James. The experience economy: Work is theater and every business a stage. Cambridge, MA: Harvard Business Press, 1999. Foi revisado em 2013, publicado como capítulo: PINE, B. Joseph. II; GILMORE, James. The experience economy: past, present and future. In.: Handbook on the Experience Economy. Edward Elgar, 2013.
} 
ao que ele respondeu: "Seria uma experiência, pois a customização em massa transforma automaticamente um serviço em uma experiência", e então ele teria dito a si mesmo: "Uau, isso soa bem!", e teria parado a aula para anotar sua epifania. Em suas conclusões, o autor considerou que, entregando o serviço exatamente certo — precisamente o que um indivíduo necessita ao longo de um período de tempo , só poderia transformar o próprio serviço em um evento memorável - uma experiência -, o que a tornaria uma oferta econômica tão distinta dos serviços quanto estes eram dos bens.

Isto significava que, segundo o autor, o "mundo desenvolvido" [grifo nosso] passaria para uma economia de experiência, suplantando a economia de serviço, assim como esta havia superado a economia industrial na segunda metade do século $\mathrm{XX}$, a qual, por sua vez, teria destruído a economia agrária no século anterior. ${ }^{26}$ Joseph (2013, p. 23) refinou sua ideia, traçando distinções entre as quatro ofertas econômicas - commodities, bens, serviços e experiências - e nisto ele se juntou a James Gilmore, que era chefe de uma empresa de consultoria em inovação, e ambos postularam, no texto de 1998, aquilo que consideravam uma mudança fundamental no tecido da economia, algo que, conforme os autores, ajudaria os executivos a pensarem de forma diferente sobre a criação de valor econômico para seus clientes: a noção de Economia da Experiência.

Mas em que consiste, então, a ideia de Economia da Experiência? Neste subcapítulo trabalharemos sobretudo com os escritos de Pine e Gilmore, pois são eles os autores citados por praticamente quase todos os textos acerca da noção de Design de Experiência desde 2000. Trabalharemos sobretudo com o texto de $2013^{27}$, visto que ele apresenta considerações e críticas à primeira versão da teoria, de 1998, relevantes à nossa discussão. Entretanto, para uma explicação mais completa à pergunta acima proferida, voltaremos agora ao texto originário, de 1998, pois é curioso que no texto de 2013 a proximidade com o Campo do Design tenha diminuído consideravelmente, afinal, o texto gira em torno de argumentos de explicação de defesa que são, sobretudo, econômicos, e não da ordem do Design.

\footnotetext{
${ }^{26}$ Há controvérsias acerca dessa suplantação e destruição, mas retornaremos a essa discussão no capítulo 3 - Da mercadoria, quando trataremos mais amiúde das mudanças econômicas e a noção de mercadoria. No momento, serve-nos apenas a explicação do que é a economia da experiência nos termos dos autores que a criaram.

27 Ver referência na nota 25.
} 
Deste modo, segundo Pine e Gilmore (1998, p. 97), a Economia da Experiência seria uma frente da Economia orientada a atender às necessidades dos consumidores, àquilo que eles pedem, querem e desejam. Eles discorrem que podemos perceber e descrever esta diferença em relação às outras frentes da Economia, porque os consumidores "inquestionavelmente" desejam experiências e, por isso, cada vez mais negócios estão respondendo a este desejo, principalmente através da forma e da interação — o "Design" dos objetos — e da promoção de experiências. Eles afirmam que, assim como serviços e bens se tornaram mercadorias (became commoditized), as experiências surgiram como um novo passo para alcançar uma progressão do valor econômico, ou seja, para aumentar o lucro de empresas. Logo, para alcançar essa progressão, os autores afirmam que as empresas devem ser um palco, devem encenar experiências, e devem considerar a experiência não algo amorfo, pois eles a consideram tão "real" como qualquer serviço ou mercadoria. (PINE e GILMORE, 1998, p. 98) Ainda, eles postulam que os donos de negócios não devem simplesmente embrulhar as experiências em torno de seu tradicional produto para vendê-la como uma embalagem: por serem palcos, eles devem cobrar pela experiência em si e, para isso, os autores sugerem uma análise de características de experiências e estudo de princípios de Design de Experiência que possam ajudar nessa nova perspectiva.

Com efeito, Pine e Gilmore (1998, p. 98-99) afirmam que uma experiência ocorre quando uma empresa intencionalmente utiliza um serviço como palco e mercadorias como adereços para engajar consumidores individualmente, de maneira que um momento único e memorável seja criado. Afirmam: "commodities são fungíveis, bens tangíveis, serviços intangíveis e experiências memoráveis" (PINE e GILMORE, 1998, p. 98). Logo, os "compradores de experiência", como os próprios autores cunham, seriam aqueles que valorizam o que as empresas apresentam ao longo do tempo, ou seja, fidelidade de serviços e de mercadorias, e não necessariamente interações isoladas. Eles usam um exemplo da indústria do entretenimento, a Walt Disney, que chama seus visitantes de "convidados" ao invés de compradores, e comentam que enquanto ofertas econômicas "anteriores" como bens e serviços - eram externas ao comprador, a experiência seria algo interno, pessoal, existindo apenas na mente de um indivíduo que tenha se engajado emocionalmente, fisicamente, intelectualmente ou até mesmo espiritualmente com a experiência. Logo, eles afirmam que duas pessoas não podem ter a mesma 
experiência, já que essa se trata da ordem do abstrato, da interação do estado de espírito de cada um com a experiência apresentada ou oferecida. Neste sentido, como podemos, então, projetá-las? ${ }^{28}$ A questão fica em aberto.

Em seguida, os autores passam para a descrição do que caracteriza uma experiência do ponto de vista da venda e salientam que, antes de mais nada, essa deve ser uma experiência pela qual os consumidores acham que vale a pena pagar. (PINE e GILMORE, 1998, p. 101) Essas experiências incluiriam, segundo os autores, excelente Design e Marketing específico, através de duas dimensões: primeiro, a participação do consumidor e, segundo, a conexão, a relação do consumidor com o ambiente em que se dá a experiência. Para a primeira dimensão, eles descrevem tanto a participação passiva, em que o consumidor não interfere na performance, como assistir a um concerto; quanto ativa, quando o consumidor faz parte da performance da experiência, como esquiadores. Para a segunda dimensão, eles também apresentam dois pontos distintos: de um lado, a absorção e, de outro, a imersão. O exemplo seria o dos espectadores de corridas de cavalos: os que assistem da arquibancada absorvem o evento, enquanto que os que assistem da pista em si estão imersos no evento, pois encontram-se em contato mais próximo com visões, sons e cheiros relativos ao que se passa. Com efeito, para Pine e Gilmore (1998, p. 102), as experiências mais ricas e valiosas seriam aquelas que englobam os quatro domínios existentes, que se encontram dentro das dimensões: entretenimento (que entretém o cliente), educacional (que educa o cliente), estético (com valores estéticos) e escapista (que dá vazão, alívio ou distração ao cliente). Quando englobadas todas, teríamos o chamado "ponto certo" (sweet spot) — e uma experiência estaria então tão bem delineada que ela poderia vir a definir um negócio. (PINE e GILMORE, 1998, p. 102) Logo, os autores afirmam que enquanto bens e serviços resultam de processos interativos de pesquisa, projeto e desenvolvimento, a experiência deriva de processos de exploração, roteirização e encenação, aspectos esses que os empresários precisariam, então, dominar.

Por conseguinte, Pine e Gilmore (1998, p. 102-105) descrevem os cinco passos para se projetar experiências memoráveis, ou melhor, o que eles definem

\footnotetext{
${ }^{28}$ Conforme Argan (1992), um projeto sempre pressupõe um resultado. Assim, como poderíamos projetar algo sobre cujo resultado não temos controle, já que duas pessoas não podem ter a mesma experiência? O que é isso que estamos projetando, então? Ver: ARGAN, Giulio Carlo. A História na Metodologia do Projeto. In: Revista Caramelo. No. 6, FAU/USP, 1992.
} 
como os cinco princípios do Design de Experiência. O primeiro princípio consiste em dar um tema à experiência, para que ela faça sentido. Conforme os autores, o tema deve ser conciso e atraente, deve compreender a missão da empresa ou um slogan de marketing e deve se fazer presente em todos os elementos e objetos presentes no palco e/ou na performance, para que uma história seja contada e faça sentido. O segundo princípio seria o de harmonizar impressões com pistas positivas, pois já que o tema forma a fundação, a experiência deveria ocorrer a partir de impressões indeléveis que a orientassem. O terceiro princípio seria o de eliminar as pistas negativas, já que os autores afirmam que assegurar a integridade da experiência requer o cuidado não apenas com a promoção de pistas positivas, mas também com a eliminação daquilo que pode desencadear contradições e distrações referentes ao tema. O quarto princípio seria o de misturar memorabilia ${ }^{29}$ ou seja, objetos de recordação da experiência. Pine e Gilmore (1998, p. 104) afirmam que a memorabilia é comparada a uma memória física do evento ocorrido, e que se as estratégias de negócio não encontram possibilidade de produção de memorabilia em uma empresa, é porque esta não está oferecendo experiências para seus consumidores. Ainda, afirmam que se seus consumidores não desejam comprar sua memorabilia, isso é sinal de que a experiência não foi boa. Por fim, o último princípio, o de envolver os cinco sentidos, consiste na ideia de que quanto mais sentidos uma experiência evoca, mais efetiva e memorável ela se torna. (PINE e GILMORE, 1998, p. 104-105) Assim, o uso de aromas para aumentar as vendas em padarias, supermercados e perfumarias é um exemplo de estímulo para a compra.

Por fim, em últimas considerações acerca do texto de 1998, os autores afirmam que não obstante formas de projetar a experiência, os supracitados cinco princípios do Design de experiência não garantem o sucesso da experiência, pois "ninguém revogou as leis de oferta e demanda." (PINE e GILMORE, 1998, p. 105) Curiosamente, entretanto, eles não discutem a supremacia das dinâmicas do modo de produção capitalista sobre o seu conceito - salvo que a Economia da Experiência é capaz de proliferar ofertas e gerar o lucro desejado. Conforme os autores, o crescimento da indústria de bens e da economia de serviços veio com "o aumento em escala geométrica" [as aspas e a afirmação são nossas] e a proliferação de ofertas que não existiam antes, que foram inventadas por designers e

\footnotetext{
${ }^{29}$ De acordo com o Dicionário Houaiss, fatos ou coisas que suscitam memórias ou lembranças; do adjetivo em latim memorabilis, digno de memória, memorável.
} 
marqueteiros. Neste sentido, a Economia da Experiência seguiria o caminho de invenção de novas ofertas. Faz-se relevante enfatizarmos aqui este ponto da vertente orientada pelo mercado: mesmo fazendo uso do discurso de suprir necessidades humanas que buscam por experiências, essa vertente reconhece a capacidade econômica e política de inculcação, o que não vimos com muita evidência na vertente humanista.

Retornando ao texto de 2013, Pine e Gilmore (2013, p. 21) apontam que muitos fatores teriam contribuído para a aceitação e ampliação da ideia de Economia da Experiência, entre eles o que chamam de experience thinking, ou pensar sobre a experiência, o qual teria proporcionado novas possibilidades de atividades de criação de valor. Além disso, a ideia de que consumidores avaliam experiências mais do que bens e serviços também caracteriza um fator, pois, conforme os autores, independentemente de sua indústria ou vocação, os consumidores apreciam mais as experiências em suas vidas que objetos físicos, e certamente mais do que os serviços mundanos. Assim, os autores discorrem que executivos e gerentes em várias empresas - empresas com fins lucrativos, instituições de caridade sem fins lucrativos, agências de turismo, agências de propaganda, sistemas de saúde, faculdades e universidades, campanhas políticas e até igrejas - teriam visto nas experiências um meio inexplorado para se diferenciar. Logo, eles afirmam que certos métodos de pesquisa e metodologias de inovação - etnografia, Design thinking, habilidades de improvisação —, que haviam sido largamente negligenciados por décadas, repentinamente encontraram uma oportunidade de interesse.

Para descrever o contexto de ocorrência da noção de Economia da Experiência, Pine e Gilmore (2013, p. 22) afirmam que o mundo se tornou mais experiencial intencionalmente, o que representa uma mudança fundamental no próprio tecido da economia global. Segundo os autores, concentrar-se apenas em bens e serviços leva ao caminho da economia de austeridade - porém, eles não explicam como isso ocorre. Assim, considerando as experiências uma forma distinta de produção econômica, elas ditariam um caminho para promover a prosperidade econômica: em todo o mundo, os bens e os serviços deveriam dar lugar às experiências como a forma predominante de nova produção econômica, como base do crescimento do produto interno bruto (PIB) e fonte de criação de novos empregos. Além disso, eles afirmam que as "economias inferiores" [nosso 
grifo] ao redor do planeta, geradas pelas tentativas financeiras desesperadas de sustentar um mundo de bens, agora configuram o momento perfeito para considerar a inexplorada inovação baseada na experiência e expansão econômica. É curioso observar aqui que os autores não discutem a produção e relevância dos objetos e da materialidade que propicia a ocorrência dessas experiências, nem a necessidade de existência, no modo de produção capitalista, de "economias inferiores", as quais, através da mão de obra barata, sustentam as economias desenvolvidas. Neste sentido, perguntamo-nos: seria realmente possível que as experiências se tornem as bases de um sistema econômico?

Em continuidade, Pine e Gilmore (2013, p. 23) mencionam que eles não foram os primeiros a pensar sobre a Economia da Experiência. Anteriormente às suas descobertas - e de seu desconhecimento quando formularam a primeira versão da teoria, em 1998 —, outros autores já haviam tratado da questão da experiência na economia em forma embrionária. Eles citam Alvin Toffler, que, em 1970, escreveu um capítulo intitulado The experience makers ${ }^{30}$, no qual questionava para onde a economia iria após os serviços, ao que respondeu "com o crescimento de um novo setor estranho, baseado no que só pode ser chamado as indústrias da experiência." (TOFFLER, 1970, p. 221) Antes de Toffler, em 1959, o sociólogo Erving Goffman, em The presentation of self in everyday life $e^{31}$, aplicou os princípios do teatro ao trabalho e às situações sociais, não como uma metáfora, mas como um modelo, no qual os autores se inspiraram para a supracitada ideia de empresas como palcos. James Ogilvy, cofundador da Global Business Network, escreveu, em 1985, The Experience Industry ${ }^{32}$, um relatório para a SRI International demonstrando que a demanda por "experiências vívidas" já havia impulsionado o crescimento marginal na economia dos EUA. Em 1992, Gerhard Schulze escreveu sobre a sociedade da experiência em Die Erlebnisgesellschaft: Kultursoziologie der Gegenwart ${ }^{33}$ e, em 1999, Rolf Jensen, do Copenhagen

\footnotetext{
${ }^{30}$ TOFFLER, Alvin. Future Shock. New York: Bantam Books, 1970.

${ }^{31}$ GOFFMAN, Erving. The Presentation of Self in Everyday Life. New York: Anchor Books, 1959.

32 OGILVY, James. The Experience Industry: A Leading Edge Report from the Values and Lifestyles Program. In.: CA: SRI International Business Intelligence, 1985.

${ }^{33}$ SCHULZE, Gerhard. Die Erlebnisgesellschaft: Kultursoziologie der Gegenwart. Frankfurt am Main: Campus Verlag, 1992.
} 
Institute for Future Studies, publicou The Dream Society. ${ }^{34}$ Semelhante a Toffler, mas tomando um ponto de vista mais sociológico do que econômico, Jensen questionou: "O que vem depois da sociedade da informação?" ao que teria respondido "a sociedade dos sonhos", que seria uma nova sociedade na qual empresas, comunidades e pessoas, como indivíduos, prosperariam com base em suas histórias, e não apenas em dados e informações.

Ainda com base em referências anteriores, porém trazendo uma nova oferta econômica neste texto de 2013, Pine e Gilmore (2013, p. 25) afirmam que toda economia é definida por sua oferta econômica predominante e, assim, seguindo James Brian Quinn (1992) ${ }^{35}$, eles apresentam a seguinte síntese: i) commodities correspondem a componentes materiais dos produtos; ii) bens ${ }^{36}$ são formas de realização física para os serviços que entregam; iii) serviços são atividades temporais para as experiências que criam; iv) experiências correspondem a eventos memoráveis para as transformações que habilitam; v) transformações são as possibilidades terrestres para a perfeição que Deus pode instilar um dia. Segundo os autores, as transformações correspondem ao que viria após a experiência, pois eles consideram que uma experiência bem projetada, customizada para um cliente em específico, pode transformar, mudar a sua vida. Antes de prosseguirmos, uma nota: consideramos curiosa essa menção a Deus — será a próxima oferta econômica após a transformação?

Em continuidade, Pine e Gilmore (2013, p. 25-26) condenam o que consideram a comoditização ${ }^{37}$ de serviços e experiências e, discorrendo sobre um posicionamento incerto em 1998, consideram que experiências não podem ser comoditizadas. Afirmando, contudo sem explicar o motivo, que as pessoas

\footnotetext{
${ }^{34}$ ROLF, Jensen. The Dream Society. New York: McGraw- Hill, 1999.

${ }^{35}$ QUINN, James B. Intelligent Enterprise: A Knowledge and Service Based Paradigm for Industry. New York: The Free Press, 1992.

${ }^{36}$ De acordo com o Dicionário Houaiss, quase sempre empregado no plural, o bem é tudo aquilo que serve de elemento a uma empresa ou entidade para a formação do seu patrimônio e para a produção direta ou indireta do seu lucro.

37 Comoditização — ou comodificação — consiste em uma transformação de relações anteriormente não mantidas pelo comércio - em relações comerciais, relações de troca, de compra e venda, ou seja, o processo pelo qual um valor econômico é atribuído a algo que não o possui, indicando uma substituição de valores sociais por valores de mercado. Trataremos mais amiúde do significado deste termo no Capítulo 3 - Da mercadoria. Agora, carece apenas chamarmos atenção para o seu uso no texto de Pine e Gilmore.
} 
passaram a valorizar mais os serviços que os bens e que, por isso, esses passaram a ser considerados commodities, os autores postulam que para combater essa "crescente comoditização" faz-se necessário investir na customização das ofertas. Continuam postulando que as pessoas "compram" [grifo nosso] cada vez mais experiências, como ir a um concerto musical, a uma peça teatral ou a um evento atlético; visitar um museu, galeria de arte ou destino distante; jogar um jogo ou esporte; tomar um café com amigos; ter uma festa de aniversário. Segundo os autores, estas não configuram novas ofertas econômicas: as memórias advindas das performances destes eventos é que adquirem novo valor [grifo nosso]. Assim, eles consideram que o valor da experiência persiste na memória de qualquer indivíduo que tenha sido envolvido pelo evento e que, não obstante as próprias experiências não tenham tangibilidade [grifo nosso], as pessoas as desejam porque seu valor permanece dentro delas.

Ao discorrerem sobre as implicações da Economia da Experiência em 2013, Pine e Gilmore (2013, p. 26-27) consideram cinco frentes: i) customização em massa como norte; ii) trabalho é teatro; iii) autenticidade como nova sensibilidade do consumidor; iv) experiência como marketing e v) cobrança de admissão como chave econômica.

Sobre i) customização em massa como norte, os autores afirmam que ela é o antídoto para a comoditização, pois permite ofertas diferenciadas, únicas. Como resultado, os autores consideram que as empresas criam ofertas mais relevantes para os desejos e necessidades de seus compradores individuais, diferenciam seus produtos e serviços do mar de aparência dos concorrentes e, assim, aumentam tanto o valor fornecido quanto o preço cobrado. Os autores ressaltam que enquanto as mercadorias, os bens e serviços existem externamente ao consumidor, as experiências ocorrem dentro deles. Logo, eles consideram que sensações, impressões e performances devem ser orquestrados para envolver cada consumidor e criar uma memória, o que faz da customização um ponto-chave no palco de experiências.

Em ii) trabalho é teatro, Pine e Gilmore (2013, p. 28-29) afirmam que se a oferta econômica de uma empresa é uma experiência, então, conforme já discorrido, o trabalho desta empresa é um teatro, uma encenação teatral.

Em iii) autenticidade como nova sensibilidade do consumidor, os autores consideram que o consumidor não deseja experiências falsas, mas sim o que é 
genuíno, autêntico, e num mundo que eles definem como cada vez mais irreal curiosamente, o mundo das experiências — os consumidores optam por comprar ou não comprar com base em quão reais eles percebem ser uma oferta. Por autenticidade, eles consideram comprar em conformidade com a sua autoimagem, buscando ofertas econômicas que correspondam tanto à sua representação quanto percepção.

Em iv) experiência é marketing, Pine e Gilmore (2013, p. 30) discorrem sobre a competitividade do mercado e, consequentemente, a luta pelo tempo, atenção e dinheiro [grifo nosso] de seus potenciais clientes - o que eles chamam de as moedas da Economia da Experiência [grifo nosso]. Assim, eles afirmam que o tempo, a atenção e o dinheiro que um cliente dispensa para determinada empresa é um tempo gasto apenas naquela empresa, e não em outra.

Por fim, em v) cobrança de admissão como chave econômica, os autores postulam que a história de todo progresso econômico consiste em cobrar por aquilo que um dia foi gratuito [grifo nosso]. Deste modo, os autores consideram que na Economia da Experiência, em vez de confiar puramente em seus próprios recursos para experimentar o novo e maravilhoso, as pessoas cada vez mais pagam mais às empresas para realizar experiências por/para elas. Logo, eles afirmam que "agora paga-se empresas por serviços que antes fazíamos, bens que antes produzíamos e mercadorias que antes extraíamos." (PINE e GILMORE, 2013, p. 31)

Em continuidade, Pine e Gilmore (2013, p. 31) afirmam que houve objeções à sua teoria ao longo dos mais ou menos vinte anos em que o primeiro texto foi publicado. Faz-se necessário tratarmos destas aqui, uma vez que elas serão importantes insumos para nossas considerações no Capítulo 3 - Da mercadoria e no Capítulo 4 - Crítica da experiência como mercadoria no Campo do Design. Primeiramente, eles discorrem sobre a adoção de distintos termos para um único significado. Termos como "Economia da Informação", "Economia do Conhecimento" e "Economia de Atenção" são alguns dos considerados irregulares, posto que modelos econômicos, segundo os autores, sempre foram nomeados com base na sua oferta (economia de serviços para serviços, por exemplo), ou de acordo com o domínio do trabalho (economia agrária para commodities, economia industrial para bens). Assim, os autores julgam que a única alternativa legítima à Economia da Experiência seria "Economia Teatral", o que avaliam muito menos prático, especialmente devido a um possível equívoco sobre trabalho é teatro, e não 
trabalho como teatro. Entretanto, os autores afirmam que "experiência" estaria mais correto, pois o que há de novo na economia em questão são justamente as experiências que representam a base da atividade econômica.

Outro ponto abordado pelos autores foi que alguns interpretaram sua concepção de experiência apenas como entretenimento. Contra isso, Pine e Gilmore (2013, p. 32) indicam que as quatro letras "e" - entretenimento, educacional, estético e escapista - são parte componente de uma experiência. Soma-se a esta a interpretação de que todas as experiências tendenciam ao inautêntico ou virtual: conforme os autores, a Economia da Experiência permite uma vasta gama de ofertas alternativas, que vão dos mais aos menos naturais/artificiais, originais/imitações, genuíno/falso, real/irreal, autocentrado/focado em outrem - em todas as dimensões do tempo, do espaço e da matéria. Já sobre distintos termos e significados para a palavra experiência - uma parte relevante para o nosso trabalho discutida na parte 2.2 deste capítulo - Pine e Gilmore (2013, p. 32) afirmam que a experiência pensada na Economia da Experiência abrange tanto aquela que está relacionada à noção de Erlebnis ${ }^{38}$ — experimentação momentânea - quanto Erfahrung - experiências que ocorrem ao longo do tempo e que são motivo de reflexão.

Outra crítica proferida a seus escritos é que eles tomam um ponto de vista empresarial, deixando de lado a dimensão do indivíduo. Sobre isso - e diante da afirmação de Jeremy Rifkin (2000) $)^{39}$ de que eles transformam "tudo na vida" em uma "experiência paga" -, os autores afirmam que certamente reconhecem esferas não-econômicas de experiência social e pessoal, não obstante seu foco seja, de fato, o econômico. Pine e Gilmore (2013, p. 33) discorrem: "nos declaramos culpados pelo ponto de vista empresarial, pois somos capitalistas que procuram ajudar as empresas a criar um maior valor econômico para seus clientes, mas em momento algum consideramos que deixamos o indivíduo de lado, pois acreditamos firmemente que a maneira de criar um maior valor econômico para os clientes é justamente atender e entender a esse cliente individual". Com efeito, eles

\footnotetext{
${ }^{38}$ Estes termos são utilizados na língua alemã para distinguir dois tipos de experiência e trataremos deles mais amiúde no subcapítulo 2.2 - Variações sobre um tema universal.

${ }^{39}$ RIFKIN, Jeremy. The Age of Access: The New Culture of Hypercapitalism, Where all of Life is a Paid- for Experience. New York: Jeremy P. Tarcher and Putnam, 2000.
} 
complementam que a megatendência que, de fato, incorpora a customização em massa é mais bem resumida justamente como "individualização", ou seja, "criar mais valor" [grifo nosso] para os indivíduos, aproximando-se cada vez mais de uma noção estranha, mas que é hegemônica em nossos dias, de oferecer aquilo que cada indivíduo quer e precisa, culminando com as ofertas de transformações que "mudam” [grifo nosso] o indivíduo. Daí já partem do princípio de que sabem o que as pessoas "querem" ou "precisam". Ora, aquilo que as pessoas "querem" ou "precisam" é resultado das práticas e relações sociais, por isso são abstratas, mas sempre de acordo com os valores de um determinado período histórico. O que é válido hoje poderá não ser amanhã. Trata-se de reforçar a autoritária noção de que é necessário impor aquilo que as pessoas "querem" ou "precisam".

Outra crítica enfatiza o papel da co-criação na formação de experiências, pois Pine e Gilmore (2013, p. 34) consideram que julgam sua visão como insuficiente em relação ao papel dos clientes e convidados na criação de suas próprias experiências. Eles justificam que, de fato, por operarem mais ao lado da oferta que da demanda, tal crítica procede, mas que eles tomam cuidado em reconhecer tal papel em suas considerações. Outra crítica afirma que os autores colocaram muita ênfase em experiências como eventos memoráveis, e não algo do cotidiano. Sobre isso, Pine e Gilmore (2013, p. 35) discorrem que, como imaginam experiências envolventes, devem considerar uma multiplicidade de dimensões, as quais incluem desde a natureza multissensorial das experiências, seu nível de significado pessoal, a maneira como a experiência é compartilhada com os outros, a intensidade e duração de vários elementos experienciais, complexidade (ou simplicidade), além de outras características de como as pessoas passam o tempo. Neste sentido, considerações culturais e sensibilidades locais, bem como as experiências de vida anteriores dos convidados, tudo impacta sobre como as pessoas percebem experiências e, por isso, constitui o que eles consideram eventos memoráveis.

Em continuidade, Pine e Gilmore (2013, p. 38-40) discorrem sobre potenciais oportunidades de criação de valor que devem impulsionar ainda mais o progresso na evolução da Economia da Experiência. Cobrar pelo tempo - a moeda principal da experiência - pode abranger desde cobrar a admissão para a entrada em um local à cobrança de acesso a algum serviço, como Netflix, o que faria os capitalistas se questionarem: “o que devemos fazer diferente se vamos cobrar?", 
com o intuito de melhorar a oferta. Também, para os autores, engajar o virtual e o real de uma maneira mais satisfatória, sobretudo através da tecnologia, constitui uma forma de progresso. Eles afirmam que já que as pessoas cada vez mais dependem da tecnologia, devem-se buscar formas de integrar realidade e virtualidade, pois “as melhores experiências ainda são aquelas do 'mundo real', e não virtual." (PINE e GILMORE, 2013, p. 39) Ainda, eles advogam pela customização de experiências e a consequente produção de transformações, pois é só a partir delas que os consumidores retornam. Os autores dão o exemplo de uma academia: os alunos pagam para obterem resultados e não sofrerem. O mesmo com um psiquiatra: as pessoas retornam se vivenciam melhoras em sua saúde mental. Neste sentido, eles postulam que, à medida em que a atividade econômica se afasta cada vez mais de bens e serviços, aquelas empresas que vivenciam experiências sozinhas - sem considerar o efeito que essas experiências terá sobre os participantes e sem projetar as experiências de forma a criar uma mudança desejada - acabarão por ver suas experiências tornarem-se comoditizadas, ou seja, experiências que, depois de repetidas duas, três vezes, perdem sua capacidade de engajamento. Mas experiências não deviam ser únicas? Ou elas podem ser repetidas uma, duas, três vezes? Assim, quando uma experiência é customizada apenas para um indivíduo, fornecendo exatamente o que ele precisa naquele momento, ela torna-se automaticamente uma transformação. Logo, os autores consideram que, ao organizar uma série de experiências que transformam, as empresas são mais capazes de alcançar um efeito duradouro no consumidor, em vez de um evento isolado.

Por fim, eles afirmam que com as transformações, os clientes acabam virando o produto [grifo nosso]. Segundo os autores, o comprador individual da transformação quer mudança e, neste sentido, deve-se considerar que a oferta econômica de uma empresa não são os materiais que usa, nem as coisas físicas que faz; não são também os processos que executa, nem os encontros que orquestra: quando uma empresa orienta as transformações, a oferta é o indivíduo. (PINE e GILMORE, 2013, p. 40) Deste modo, os autores consideram que as empresas que propiciam as transformações deveriam cobrar não apenas pelo tempo, mas também pelas mudanças resultantes da transformação nesse tempo: elas devem cobrar pelos resultados, e não só pelo meio de atingir tais mudanças que modificam a vida, especialmente nas indústrias que se concentram em tornar as pessoas saudáveis, 
ricas e sábias. Pine e Gilmore (2013, p. 41) finalizam o texto afirmando que as empresas devem se concentrar em alcançar o "interior" do consumidor, sua vida, sua respiração, fazendo suas ofertas tão pessoais e individuais como o próprio cliente deseja. Ainda, postulam que a mudança para a economia da experiência hoje, na qual as experiências se tornaram a oferta econômica predominante, constitui a principal fonte de criação de emprego e crescimento econômico.

Vimos aqui que os argumentos base para o desenvolvimento da noção de Economia da Experiência abrem espaço para diversos questionamentos acerca da dinâmica do modo de produção vigente - o capitalismo tardio — e sua relação com a prática do Campo do Design. Alguns desses questionamentos já apontamos brevemente no decorrer do texto, mas sua formulação e discussão tomarão forma final no Capítulo 4 - Crítica da experiência como mercadoria no Campo do Design, visto que o Capítulo 3 - Da mercadoria nos propiciará insumos para tal. Um ponto que talvez seja relevante já mencionar é que, conforme pudemos perceber pela leitura recém finalizada, a visão do Design de Experiência pela vertente orientada ao mercado também faz uso de considerações da ordem humanista, mas estas sucumbem às — ou melhor, são expressão das — demandas do modus operandi do modo de produção capitalista. Quando Pine e Gilmore (2013, p.39-40) afirmam que empresas devem alcançar o "interior” do consumidor, sua vida e respiração, e que a oferta é o indivíduo, parece haver qualquer inconsistência com um discurso de suprimento de necessidades e melhora da existência humana. Neste sentido, faz-se mister agora compreendermos mais amiúde como, de fato, são construídas e formuladas as noções de Design de Experiência no Campo do Design, quais seus desdobramentos projetuais e sua relevância social, considerando tanto a vertente humanista quanto a orientada pelo mercado. Na verdade, estamos nos perguntando se os designers desenham aquilo que as pessoas "precisam" ou "querem" ou se desenham apenas aquilo que seus patrões dizem que as pessoas "precisam" ou "querem".

\subsection{3.}

\section{O que é, afinal, Design de Experiência?}

“Abro meus olhos. A luz exuberante inunda a sala, os pássaros cantam. São apenas 6h30 da manhã, mas me sinto bem descansado e vivo; hora de levantar, preparar 
um café. Você está com ciúmes da minha rotina matinal? Você acordou assustado de seu sono por um despertador implacável? Estava escuro lá fora, sem pássaros ao redor, e você se sentia grogue e com olhos lacrimejantes?"

A descrição deste despertar é feita por Marc Hassenzahl, ao iniciar seu texto sobre User Experience e Experience Design na Encyclopedia of Human-Computer Interaction (2011)..$^{40}$ Ele descreve esse despertar matutino que ocorre com o auxílio da Philips' Wake-up Light, um objeto híbrido, mistura de despertador e luminária de cabeceira da marca Philips, que apresenta algumas funções que vão além das de um despertador ou luminária comuns. Segundo o autor, trinta minutos antes da hora marcada para despertar, o objeto começa a emitir uma luz suave, a qual vai aos poucos aumentando de intensidade, simulando o nascer do sol e, chegada a hora de acordar, a luz em sua luminosidade máxima é somada à emissão de sons que imitam o canto dos pássaros e, voilà, um despertar mais leve e encorajador pode ocorrer. Apesar de considerá-la uma experiência substituta [grifo do autor], pois ela não é capaz de reproduzir com acuidade a realidade da experiência criada pelo sol e pelos pássaros, o autor a qualifica também como substancial [grifo do autor], uma vez que ela é capaz de, através da tecnologia, mudar a forma de despertar, modificando assim uma experiência. Entretanto, o que faz deste despertar uma experiência única, já que este é um pressuposto comum tanto às considerações da vertente humanista quanto mercadológica da noção de Design de Experiência no Campo do Design? E qual a dimensão do usuário, outro pressuposto básico, na necessidade, criação, desenvolvimento e uso deste primeiro projeto e depois produto de Design de Experiência?

Vimos que ambas as vertentes recém citadas afirmam que o usuário se torna o objeto - ou produto, ou oferta — da prática do Campo do Design. Entretanto, ambas as vertentes também contam com críticas a essas concepções: na humanista, que o ponto principal ainda é o objeto físico, tendo em vista que o usuário é sempre uma concepção a posteriori do objeto - ainda que se pense nele antes do produto, ele só poderá agir a partir do produto/interface projetado — , e na mercadológica, que os projetos de experiência são desenvolvidos para suprir as chamadas "necessidades humanas". Essa consideração, que abarca também a vertente

\footnotetext{
${ }^{40}$ HASSENZAHL, Marc. User Experience and Experience Design. In: Encyclopedia of HumanComputer Interaction. The Interaction Design Foundation, 2011.
} 
humanista, considera que essas experiências desses consumidores não podem ser comoditizadas.

Assim, diferente da possibilidade de separação - conforme aquela que efetuamos para explicar as duas vertentes de fundamentação das definições de experiência no Campo do Design — no caso das definições em si essa possibilidade inexiste, isto porque, na maior parte dos casos, ambas se combinam, sobretudo utilizando a vertente humanista como justificativa para a mercadológica. Hilary McLellan (2000, p. 59) ${ }^{41}$, por exemplo, define anacronicamente e acriticamente o Design de Experiência como uma prática antiga, que remonta aos primeiros impulsos humanos por desenvolver rituais, cerimônias, narrativas e até mesmo a Arquitetura, já que estes eram concebidos ou projetados, conforme a autora, para fornecer determinados tipos de experiência. Entretanto, ele teria se tornado mais relevante no século XX, no qual a mídia - rádio, televisão, aparelhos multimídia, realidade virtual, internet - teve papel central. A autora afirma ainda que o Design de experiências é formado também por novas ideias advindas da Economia, especialmente a partir dos escritos de Pine e Gilmore (1998) sobre a noção de Economia da Experiência, bem como da Inteligência Artificial, da Psicologia, da Sociologia, do comércio eletrônico, do Design persuasivo de interação humanocomputador, de histórias e de narrativas digitais. Deste modo, faz-se mister agora visualizarmos e discutirmos algumas dessas combinações, com vias a obter insumos para a crítica da experiência como mercadoria no Campo do Design.

\subsubsection{1.}

\section{Definições experienciais}

Uma das primeiras definições que se faz relevante conhecermos - e que é anterior ao marco fundador do texto Welcome to the Experience Economy, de Pine e Gilmore em 1998, trabalho que deu origem a muitos dos textos que trataremos a seguir - é a de C. Thomas Mitchell, que em 1993 publicou um livro intitulado Redefining Desiging - from form to experience. ${ }^{42}$ Neste livro, o autor define e

\footnotetext{
${ }^{41}$ MCLELLAN, Hilary. Experience design. In.: CyberPsychology \& Behavior, v. 3, n. 1, 2000.

${ }^{42}$ MITCHELL, C. Thomas. Redefining designing; from form to experience. Van Nostrand Reinhold, New York, USA, 1993.
} 
advoga pelo termo intangible Design, o qual ele considera o Design da experiência em si. Com exemplos que não se restringem apenas à Arquitetura - tema central do livro - , mas também ao uso de software — já que ele dá exemplos de interfaces e outros projetos -, Mitchell (1993, p. 119) afirma que o Design intangível diz respeito à escala do sistema, à escala dos padrões invisíveis e intangíveis de experiência e uso. Através do Design intangível, as ações e experiências das pessoas, ao invés da capacidade tecnológica ou dos critérios geométricos, é que se tornam a base para projetar. Neste sentido, o autor postula que o foco do Design intangível é o uso, a utilidade, e afirma que quando a natureza das tarefas de Design muda a forma dos objetos de atender essa ou aquela função, isto é, quando essa natureza passa de uma demanda social precisa para a função dinâmica de um sistema através do tempo — ou, se preferirmos, para uma dinâmica de trocas simbólicas $^{43}$ —, os métodos de Design orientados para o objeto tornam-se inaplicáveis. Com efeito, Mitchell (1993, p. 119-120) então considera que algumas abordagens surgiram para preencher essa lacuna, como o sistema de Design centrado no Usuário. Ainda, o autor afirma que estava se tornando evidente, em vista ao grande número de projetos premiados que falharam [grifo nosso] em testes de uso, que os critérios da comunidade de Design para projetos de sucesso diferem radicalmente daqueles dos usuários de Design: conforme o autor, designers julgam seus trabalhos de acordo com critérios estáticos, geométricos, enquanto usuários estão preocupados com os processos dinâmicos e experienciais da utilização de objetos. Logo, o autor discorre que os critérios estáticos e geométricos do Design da era industrial deveriam ser abandonados em favor do foco nas experiências dinâmicas e multissensoriais dos usuários, o que ele denomina Design sensível ao Usuário - User-sensitive Design. O autor afirma que a prática do Design deve mudar do foco em produtos para a preocupação com processos e, assim, abordar os processos dinâmicos de experiência e uso ao nível dos sistemas; por exemplo, através da criação de tecnologias que funcionam por causa de pessoas, e não apesar delas. (MITCHELL, 1993 p. 132)

$\mathrm{Na}$ esteira de definiçõos surgidas a partir de 2000, quando tivemos, conforme supracitado, uma proliferação de publicações sobre Design de Experiência, após a adoção do termo Economia da Experiência, uma edição da

\footnotetext{
${ }^{43}$ Termo cunhado por Pierre Bourdieu (2001). Ver nota 4 para referência.
} 
revista Gain $^{44}$, intitulada (Form + Content + Context $)$ Time $=$ Experience Design, a AIGA (The Professional Association for Design) abordou o tema Experience Design. Richard Grefé, o então editor executivo, escreveu no editorial que uma nova disciplina do Design estava emergindo das necessidades e formas da comunicação na economia das redes (network economy). "Design de experiência", conforme o autor, "é uma disciplina criada a partir da realidade da comunicação hoje, quando nenhum ponto de contato tem um simples início e fim e todos os pontos de contato devem ter significados". Com efeito, o que antes era responsabilidade do Design Gráfico - a forma e o conteúdo da comunicação agora é de responsabilidade do Design de Experiência, que considera a forma, o conteúdo e o contexto da comunicação ocorrendo através do tempo. Segundo Grefé (2000, p. 1), o Design de Experiência reconhece os imperativos da experiência da marca e as características da experiência do usuário. O autor afirma que o Design não agrega valor a essa economia: o Design cria [grifo nosso] o valor. Assim, para Grefé (2001, p. 1), o Design de experiência é a proposital criação de valor na economia das redes, geralmente através da criação de relações no mundo do $e$ commerce.

Antes de avançarmos, é preciso que saibamos que essa noção foi formulada de modo confuso ou equivocado. Esse editorial não define com clareza qual é o valor ao qual se refere. Em primeiro lugar, confunde o valor social com o valor mercantil. Depois, afirma que "criar" um valor é o mesmo que produzi-lo. Ocorre que o editorial não está fazendo menção ao valor social ou produtivo, aquele que verdadeiramente produz riqueza econômica, trabalho e que resulta nas trocas de produtos. Na verdade, esse editorial está tratando de um valor simbólico, de troca simbólica, aqui, no caso, financeira ou mercantil, que não pode nem deve se confundir com o primeiro. Além disso, ainda que um valor simbólico possa ser criado, construído ou produzido, dentro do processo que vai da fábrica ao consumidor, quando tratamos do valor nos produtos industrializados, é importante lembrar que sua natureza é diferente da natureza econômica. O valor simbólico é como a especulação que o comerciante faz quando opera a comercialização do produto. Ele aumenta, digamos assim, o valor de uso do objeto à venda — “enfeita

${ }^{44}$ GREFÉ, Richard. (Form + Content + Context) Time = Experience Design. In.: Gain: AIGA Journal of Design for the Network Economy. Volume 1, number 1, 2000. 
o pavão", como se diz popularmente - para obter um ganho ou lucro a mais na última etapa do processo de produção da riqueza, que começa na fabricação daquilo que está à venda. Agregar um "valor" é, portanto, uma prática comercial ou especulativa. O problema com o qual nos deparamos agora é que isso que está sendo comercializado, ou colocado à venda, não é mais concreto ou sensível, tal como um objeto industrial o é. Um sapato tem um valor de uso social, protege os pés de quem o calça. O que está sendo trazido para discussão é se se pode cobrar pela sensação que ocorre em decorrência de calçar esse ou aquele par de sapatos. Se essa dimensão simbólica pode ser comercializada, se produz valor/riqueza ou não.

A $A I G A$, sobre uma noção equivocada, teria encorajado a criação de uma comunidade de designers de experiência - o Fórum de Design de Experiência (Experience Design Forum) —, que desafiava projetar para um mundo cada vez mais digital e conectado. A associação dizia-se firmemente compromissada em ajudar essa comunidade e os negócios de seus clientes a compreenderem a natureza e os desafios do Design de Experiência, além de desenvolver standards profissionais e éticos, expectativas educacionais e canais para comunicar o pensamento crítico sobre Design de Experiência. Curiosamente, o periódico Gain, desenvolvido para um melhor entendimento dos processos do Design de Experiência, do papel do designer e do valor de um projeto eficaz para a comunidade de negócios e a economia de redes, contou apenas com dois volumes no mesmo ano em que foi lançado e, se hoje procuramos por esse fórum online, não o encontraremos.

Retornamos agora a McLellan (2000, p. 62-63), citada ao início do subcapítulo. A autora busca definir o que considera uma experiência ideal ao discorrer sobre a proximidade do modelo proposto por Pine e Gilmore (1998) e a noção de fluxo (flow) proposta por Mihaly Csikszentmihalyi $(1991)^{45}$, o que seria uma combinação de participação ativa e imersão do tipo escapista, classificação já explicada nas considerações acerca de Pine e Gilmore (1998). A autora afirma que não obstante os estudos de Csikszentmihalyi não sejam do Campo do Design são estudos do fluxo de uma atividade em distintos contextos no Campo da Psicologia - estes complementam o entendimento da noção de experiência no Campo do Design por propiciarem o entendimento da experiência ideal enquanto

${ }^{45}$ CSIKSZENTMIHALYI, Mihaly. Flow: The psychology of optimal experience. New York: Harper and Row, 1991. 
um fim em si mesmo, ou seja, a experiência ideal seria aquela que, mesmo a serviço de determinada tarefa, enquanto autotélica (nos termos do autor), faria a alienação dar lugar ao envolvimento, a diversão substituir o tédio e o desamparo tomar a forma de controle, com a energia psíquica trabalhando para reforçar o senso de si, ao invés de perder-se em um serviço de metas externas. (CSIKSZENTMIHALYI, 1991, p. 69) Com efeito, esta experiência ideal, este estado contínuo de fluxo, só seria alcançado com a existência de um conjunto de metas que requeiram uma resposta adequada, quando o retorno ao usuário é imediato e quando as habilidades do usuário são plenamente envolvidas na superação de um desafio que é difícil, mas manejável. Com todos esses requerimentos alcançados, a experiência se tornaria uma grande aliada para negócios, por suas características de envolvimento, sentido de participação e "memorabilidade", características oriundas dos escritos de Pine e Gilmore (1998).

Ainda em 2000, Jodi Forlizzi e Shannon Ford (2000) ${ }^{46}$ discorreram sobre um crescente interesse pelo "projetar a experiência do usuário", principalmente por profissionais de negócios, empresas de Design de interação e profissionais de estratégias virtuais. Para isso, advogam pela necessidade de um entendimento mais claro, por parte dos designers, do que é a experiência humana, seus componentes e elementos e, mais importante, se realmente é possível projetar uma experiência, ou então apenas facilitar sua ocorrência ou não a impedir de ocorrer. Ainda, discorrem sobre ser necessário um melhor entendimento sobre como as pessoas interagem com $\operatorname{artefatos}^{47}$, e como essas interações afetam as experiências que elas têm. Além disso, ainda advogam por um estudo de como essas teorias, para serem úteis, devem encontrar expressão em processos de Design, materiais e formas, porém baseadas na experiência humana. (FORLIZZI e FORD, 2000, p. 419) Posto isso, as autoras começam por delimitar sistematicamente os três conceitos que reconhecem como experiência: experiência, uma experiência e experiência como história. Experiência seria o fluxo constante do que ocorre em momentos de consciência, e um exemplo seria falar para si mesmo. Uma experiência seria aquilo que John Dewey define,

\footnotetext{
${ }^{46}$ FORLIZZI, Jodi.; FORD, Shannon. The building blocks of experience: an early framework for interaction designers. DIS 2000 Conference, ACM, 2000.

${ }^{47}$ Aqui também, temos usos variados: artefatos (artifacts), objetos (objects), produtos (products).
} 
em 1934, em seu livro Arte como Experiência (1980): ${ }^{48}$ ela tem um início e fim, já o usuário e o contexto podem ser cambiantes, aspecto que propicia a mudança de resultado da experiência; e um exemplo seria presenciar uma história que fizessenos mudar nosso modo de pensar ou agir, tal como a partir de um comercial ou uma conversa. Por último, a experiência como história seria aquela que utiliza histórias para comunicar experiências em diversas situações e para distintas audiências, e um exemplo seriam jogos de fantasia.

Já Nathan Shedroff, em Experience Design $1.1(2001)^{49}$, um dos primeiros — senão o primeiro - livros dedicados apenas ao tema do Design de Experiência, afirma que, como disciplina, o Design de Experiência ainda estava em sua infância. Sem ter história — já que é uma disciplina recentemente definida —, porém, simultaneamente, tendo a mais longa história — já que é a culminação de muitas disciplinas antigas -, o autor considera que o Design de Experiência consiste da combinação de muitas disciplinas anteriores que nunca haviam estado tão interrelacionadas, nem as possibilidades de integrá-las tinham propiciado tão bons resultados. Com efeito, é porque a disciplina é tão nova que sua própria definição está em fluxo. Shedroff (2001, p. 2-3) afirma que alguns veem a disciplina apenas como um campo para mídia digital, enquanto outros a veem em termos amplos que englobam disciplinas tradicionais e já estabelecidas como teatro, Design Gráfico, storytelling, Design de Exibições, Game Design, Design de Interiores, Arquitetura e afins. O autor ainda afirma que a maior parte das experiências tecnológicas incluindo as digitais e, especialmente, online - empalideceram e, em muitos resultados, foram malsucedidas em comparação às experiências no mundo real. Logo, o que seria necessário primeiro e antes de tudo é o entendimento, pelos seus criadores e desenvolvedores, do que faz uma boa experiência e, em seguida, a tradução desses princípios, na melhor forma possível, para a mídia desejada, sem que a tecnologia dite a forma da experiência. Shedroff (2001, p. 2-3) afirma que, enquanto tudo é, tecnicamente, uma experiência de algum tipo/natureza, há algo importante e especial em muitas experiências que as faz relevantes para discussão: em particular, os elementos que contribuem para experiências superiores, os quais

\footnotetext{
${ }^{48}$ DEWEY, John. Art as Experience. New York: Perigee, 1980. Veremos que Dewey é citado muitas vezes por designers e discutiremos sua teoria mais amiúde em 2.2.2 - A experiência estética e o Pragmatismo.
}

${ }^{49}$ SHEDROFF, Nathan. Experience Design 1.1. Waite Group Press, 2001. 
são conhecidos e reprodutiveis, o que as torna projetáveis [grifo nosso]. Entretanto, ele aponta que estes elementos nem sempre são óbvios e, certamente, não são sempre infalíveis. Por fim, para Shedroff (2001, p. 4), experiências são a base para todos os eventos da vida e constituem o núcleo, o cerne do que a mídia interativa tem a oferecer. $\mathrm{O}$ autor afirma que uma das maneiras mais importantes de definir uma experiência é procurar por seus limites, que definem seu início, meio e fim. Logo, como uma história, esses limites nos ajudam a diferenciar o significado, o ritmo e a conclusão de uma experiência.

Jane Fulton Suri, em publicação de $2003^{50}$, argumenta que, diferentemente de anos atrás, quando os designers projetavam apenas as qualidades físicas de um objeto - "não obstante cientes de que esses objetos afetam as experiências das pessoas, o projeto físico deles era suficiente" —, hoje, produtos estão mais similares em tecnologia, funcionalidade, preço e qualidade e, por isso, torna-se necessário que empresas invistam mais radicalmente em modos de diferenciar sua produção e criem fortes relações emocionais com seus consumidores. Assim, os designers estariam sendo explicitamente desafiados a ajudar empresas [grifo nosso] a explorar e visualizar distintas direções para seus futuros que evoquem e suportem qualidades específicas de experiências, com fins econômicos. (SURI, 2003, p. 3940) Essa expansão de prática teria se dado por avanços tecnológicos que impactaram o comportamento de pessoas e experiências para além de objetos individuais: hoje, são desenhadas interações complexas, integradas a hardware, software, espaços e serviços - desenhos de sistemas integrados de produtos, como bancos; e também por uma maior confiança na maturidade adquirida pelos estudos de Design centrado no Ser Humano (Human-centered Design). Tal expansão também faria parte de novas estratégias de mercado [grifo nosso], em que empresas buscam vantagem competitiva ao oferecer serviços integrados, como companhias telefônicas com linhas de celular e internet - na definição de Suri (2003, p. 40), podemos claramente identificar a vertente humanista e a orientada ao mercado. Assim, a definição de Design para a experiência que a autora utiliza consiste em projetar para influenciar a qualidade da experiência. (SURI, 2003, p. 40) Ela cita Pine e Gilmore (1998) e diz que, apesar dos exemplos demonstrados, ela não acredita que seja possível projetar a experiência, mas sim para a experiência

\footnotetext{
${ }^{50}$ SURI, Jane F. The Experience of Evolution: Developments in Design Practice. In.: The Design Journal, v. 6, n. 2, 2003.
} 
[nossos grifos], já que a experiência seria algo pessoal e, apesar de os designers serem capazes de influenciá-la, esta não pode ser projetada (SURI, 2003, p. 41), pois muitos aspectos que afetam a experiência, como o estado interno de pessoas, seu humor, suas associações idiossincráticas ou o contexto, são independentes do controle do designer. Entretanto, a autora afirma que experiências também podem ser influenciadas por elementos que os designers podem controlar, como qualidades formais e sensoriais, sons, cheiros, massas, texturas, ritmos, sequências, camadas e lógica - todas qualidades expressivas inerentes a produtos, ambientes, mídias e serviços projetados. Logo, é por isso que se faz necessário que designers entendam aspectos pessoais, sociais e culturais, além de elementos de Design e suas intepretações. (SURI, 2003, p. 41)

Para Jodi Forlizzi e Katja Battarbee (2004, p. 261-262) ${ }^{51}$, o que é único à abordagem da pesquisa no Campo do Design na busca por compreender experiências é que esta pesquisa está focada nas interações entre pessoas e produtos e nas experiências que resultam dessas interações, e esta abordagem inclui todos os aspectos referentes à experiência de um produto, como físicos, sensuais, cognitivos, emocionais e estéticos. $\mathrm{O}$ entendimento de tais aspectos, quando aplicado à prática do Design de Produto, acaba por enriquecer técnicas simples de usabilidade na diferenciação de projetos concorrentes no mercado. Assim, as autoras afirmam que o termo "experiência do usuário" é associado a uma variedade de significados e que não existe uma teoria da experiência que seja comum à comunidade do Design. Os modelos e teorias de distintas áreas como Economia, Filosofia, Antropologia, Ciência Cognitiva e Ciências Sociais propiciam o agrupamento em três frentes para o entendimento da experiência: 1) centrada no produto; 2) centrada no usuário; 3 ) centrada na interação. A experiência centrada no produto, segundo Forlizzi e Battarbee (2004, p. 262), consiste em diretrizes de aplicação direta à prática do Campo do Design, fazendo uso de informações oriundas tanto de designers quanto de outros profissionais sobre o processo de "criar" [grifo nosso] produtos que evoquem experiências atraentes, descrevendo os tipos de experiências e questões que devem ser consideradas na concepção e avaliação de um artefato, serviço, ambiente ou sistema. Esses modelos geralmente consistem de listas de tópicos ou critérios para uso como lista de verificação quando em processo de projeto. Já a

${ }^{51}$ FORLIZZI, Jodi; BATTARBEE, Katja. Understanding experience in interactive systems. DIS 2004. New York, USA: ACM Press, 2004. 
experiência centrada no usuário ajuda designers e desenvolvedores a compreender as pessoas que utilizarão seus produtos. Estes métodos integram um variado número de abordagens disciplinares para compreender as ações das pessoas e aspectos das experiências que estas acham relevantes quando interagem com um produto. Conforme Forlizzi e Battarbee (2004, p. 262), esses métodos vão além dos métodos tradicionais de estudo da interação por trabalharem com modelos orientados para ação de comportamento. Por conseguinte, a experiência centrada na interação explora o papel que produtos têm na ligação entre designer e usuário. Aqui também várias disciplinas influenciam as abordagens costumeiramente utilizadas. Em termos essenciais, as autoras consideram que a experiência consiste de um engajamento total em uma relação com um objeto em uma determinada situação.

Paul Hekkert (2006, p. 158) $)^{52}$ adentra a seara da noção de experiência estética - cara ao Campo do Design, porém não muito discutida em termos críticoteóricos. Ele discorre sobre como, a seu ver, apenas parte da experiência de um acontecimento ou produto poderia ser chamada de estética - e não toda a experiência, como muitos podem pensar. $\mathrm{O}$ autor afirma que a experiência estética daria conta apenas do (des)prazer que resulta de uma percepção sensorial. Ele considera experiências eventos que têm um início e um fim e que criam um todo, seguindo Dewey (1980). Ao dar o exemplo de uso de um celular — o que poderia ser chamado, então, experiência do produto - ele questiona: essa mesma experiência poderia ser chamada de experiência estética? Ou, quais partes dessa experiência são estéticas? Em seu argumento, a experiência estética seria apenas aquela aprazível aos sentidos. Portanto, ele considera que nem toda a experiência com o produto pode ser chamada de experiência estética, já que a experiência como um todo lidaria com outras faculdades da mente humana, como cognição e emoção, e estas deveriam, portanto, serem separadas conceitualmente. ${ }^{53}$ Assim, Hekkert

52 HEKKERT, Paul. Design aesthetics: Principles of pleasure in product design. In.: Psychology Science, 48(2), 2006.

53 Conforme Abbagnano (1998), no verbete PERCEPÇÃO, foi Descartes quem estabeleceu o significado novo e mais complexo do termo em questão. Falando das percepções externas, ele afirmava que, conquanto elas sejam produzidas por movimentos provenientes de coisas externas, "nós as relacionamos com as coisas que supomos ser suas causas, de tal maneira que acreditamos ver um archote e ouvir um sino quando apenas sentimos os movimentos que deles vêm." (Les Passions de l'âme, I, 23) A partir de então a distinção entre sensação e percepção torna-se fundamental na teoria da percepção. Ver: ABBAGNANO, Nicola. Dicionário de Filosofia. $2^{\mathrm{a}}$ edição. São Paulo: Martins Fontes, 1998. 
(2006, p. 158) considera haver três níveis de experiência - estético, compreensivo e emocional - e que cada um deles, apesar de estritamente ligados, tem seu próprio processo independente. Ainda, ele considera que esses processos não são arbitrários, mas sim que seguem leis - leis que regeriam, então, nossas reações estéticas.

Faz-se mister agora tecer algumas breves considerações sobre a noção de estética. Segundo Hekkert (2006, p. 158), oriunda do grego aesthesis, a palavra estética se refere à percepção sensorial e ao entendimento ou conhecimento sensual. No século dezoito, entretanto, o filósofo Baumgarten modificou seu entendimento e passou a considerá-la uma gratificação dos sentidos ou prazer sensual ${ }^{54}$, e a atrelou especificadamente ao Campo da Arte, pois ele considerava que obras de arte eram feitas justamente para satisfazer nossos sentidos. Por conseguinte, observa-se que o conceito tem sido aplicado para variados aspectos da experiência no Campo da Arte, como julgamento estético, atitude estética, compreensão estética, emoção estética e valor estético. Deste modo, Hekkert (2006, p. 158) afirma que concorda com a definição de Baumgarten, de restringir o termo estético ao prazer advindo da percepção sensorial.

Em seguida, ao definir experiência do produto, o autor afirma que essa consiste de um conjunto de efeitos que são provocados pela interação entre um usuário e um produto, incluindo o quanto todos os sentidos são gratificados (experiência estética), o entendimento dos significados que atribuímos ao produto (experiência de significado) e os sentimentos e emoções que são desencadeados a partir da interação (experiência emocional). Já a experiência emocional consistiria de um modelo de avaliação, o qual deveria julgar um acontecimento ou situação como potencialmente benéfico ou maléfico para uma pessoa. $\mathrm{O}$ autor ainda indica que, nesses modelos, cada emoção tem um padrão distinto de avaliação; entretanto, há casos em que a relação entre a situação e a resposta emocional é o que acaba determinando a experiência emocional, já que é a interpretação, e não o acontecimento em si, o que causa a emoção.

${ }^{54}$ GOLDMAN, Alan. The Aesthetic. In.: The Routledge companion to aesthetics. London: Routledge, 2001. 
Por fim, Hekkert (2006, p. 16) discorre sobre o que chama de estética evolucionária, recorrendo às teorias de Hume $(1757)^{55}$ e Kant $(1952)^{56}$ para comprovar como princípios gerais do gosto ou do prazer estético são uniformes na natureza humana. Entretanto, o autor designa que tal pensamento não necessariamente indica acordo universal, pois mesmo que o processo por detrás de nossas emoções seja uniforme, isto não garante que distintos resultados de interpretação e também nossas respostas estéticas não possam variar dentro das leis. Assim, ele afirma que é a partir do entendimento da maneira como agimos - ou como pensamos, ou como sentimos - que podem-se explicar as vantagens desses atos para a evolução humana, principalmente porque o fenômeno estético, aparentemente inútil, oferece um prato cheio para psicólogos evolucionários o explicarem. ${ }^{57}$

Por sua vez, McCarthy e Wright (2010, p. 13-19) afirmam que, apesar da experiência parecer subjetiva, solitária, um processo introspectivo, fazer sentido do mundo é uma prática irredutivelmente social, e está intimamente ligada à ideia de voz e à ideia de narrativa. Com efeito, seu entendimento de experiência não considera que o significado lhe seja inerente, nem que este surja como uma inferência lógica da experiência. Os autores consideram que as pessoas produzem sentido e muitas vezes dependem da experiência passada ao fazê-lo. Logo, os autores postulam que, com a ajuda de outros, coproduzimos nossas experiências; não apenas as temos. A ideia de experiência como coproduzida nos leva às noções

\footnotetext{
${ }^{55}$ HUME, David. 'Of the standard of taste', in Essays, Literary, Moral, and Political. London: Ward, Loch, \& Co, 1757.

${ }^{56}$ KANT, Immanuel. The critique of judgement. (Originalmente publicado em 1790). Oxford: Clarendon Press, 1952.

${ }^{57}$ Eagleton (1993) descreve que a Estética nasce em um momento propenso: o momento político Iluminismo - em que as questões da alma deveriam ser passíveis de serem explicadas, do contrário um governo nunca conseguiria exercer seu poder de modo completo, pois os cidadãos jamais se sentiriam pertencentes a determinados valores se esses valores não tomassem conta de seus anseios mais íntimos. Logo, o autor considera que a Estética se constitui de um conceito burguês, no sentido histórico e literal, criado e nutrido pelo Iluminismo, pois, enquanto categoria teórica, a Estética está articulada ao processo material pelo qual a produção cultural, em um estágio inicial da sociedade burguesa, ganhou "autonomia" em relação às várias funções sociais a que servia tradicionalmente. Em decorrência desta mudança, os objetos se tornam bens de consumo no mercado, existindo para nada e para ninguém em particular, ou seja, existindo prioritariamente a partir de seus valores de troca, e não de seus valores de uso. Ver: EAGLETON, Terry. A ideologia da Estética. Rio de Janeiro: Jorge Zahar Editores, 1993.
} 
de agência, controle e criatividade como as partes essenciais da noção de Design de Experiência.

Por fim, nosso último autor a ser considerado nessas definições experienciais, Hassenzahl (2011), considera experiência no Campo do Design aquela criada e moldada através da tecnologia. Ele se questiona se é possível criar uma tecnologia que compreenda e reproduza as características únicas de acontecimentos como o nascer do sol e o canto dos pássaros, em exemplo supracitado ao início deste subcapítulo, e que seja capaz de proporcionar uma experiência semelhante. Além disso, Hassenzahl (2011) ressalta que o Design de Experiência ou a experiência do usuário não correspondem necessariamente a objetos bem desenhados, multi-touch ou com interfaces luxuosas, mas sim a uma transcendência do material, pois sua contribuição não é à estética do objeto, mas sim à estética de uma experiência - é sobre criar uma experiência através de um dispositivo. O autor passa a discorrer, então, acerca da mudança, nas sociedades ocidentais, de uma cultura material para uma cultura dita imaterial $^{58}$, a da experiência. Para corroborar, ele apresenta estudos ${ }^{59}$ que demonstram que compras de experiências - um ingresso para um concerto, um jantar, uma viagem — tornam as pessoas mais felizes que compras materiais, como a aquisição de objetos tangíveis - por exemplo, roupas, joias, equipamentos diversos. Hassenzahl (2011) continua discorrendo sobre outro termo que corresponde a essa linha de pensamento, o que ele chama de cultura pós-materialista. Ele menciona que sociedades em períodos de riqueza material acabam interessando-se mais por valores, como uma melhoria do âmbito pessoal, que por materialidades ${ }^{60}$, fato que abre espaço para as chamadas Sociedades da Experiência (Experience Societies) ${ }^{61}$, nas quais membros equiparam felicidade à aquisição de acontecimentos e eventos positivos em suas vidas. Schulze (2005) aponta alguns indicativos desta mudança

\footnotetext{
58 Trataremos desta questão e de suas implicações de forma amiúde no Capítulo 3 - Da mercadoria. Agora, basta apenas indicar o uso dos termos.

59 Ver: BOVEN, Leaf Van; GILOVICH, Thomas D. To Do or to Have? That Is the Question. In.: Journal of Personality and Social Psychology, 85 (6), 2003; CARTER, Travis J.; GILOVICH Thomas D. The Relative Relativity of Material and Experiential Purchases. In.: Journal of Personality and Social Psychology, 98 (0), 2010.

${ }^{60}$ Ver: INGLEHART, Ronald. Modernization and Postmodernization: Cultural, Economic, and Political Change in 43 Societies. Princeton University Press, 1997.

${ }^{61}$ Ver referência na nota 33.
} 
de comportamento: desaceleração ao invés de aceleração, menos ao invés de mais, singularidade ao invés de padronização, concentração ao invés de diversão e fazer ao invés de consumir. Hassenzahl (2011) reconhece que, para desenvolver uma cultura pós-materialista, experiencial, alimentos, roupas e abrigo ainda são necessários, mas afirma que estes não precisam ser extravagantes.

Destarte, na relação entre experiência e negócios, Hassenzahl (2011) discorre sobre como a transformação para uma sociedade da experiência pósmaterialista foi reconhecida ${ }^{62}$ pelo âmbito dos negócios, porém não totalmente absorvida. Um exemplo deste fenômeno é a indústria da música, que hoje arrecada mais em shows que na venda de discos, mas que ainda assim, seus produtores e investidores insistem na venda de discos enquanto resultado mais lucrativo monetariamente, pois o produto tangível produzido em larga escala tem maior alcance que o limite de shows que um artista pode fazer por mês. Essa dificuldade presente no exemplo de Hassenzahl (2011) reporta à escalabilidade da experiência, que aqui toma um aspecto negativo, pois não se coloca ao alcance de todos na mesma intensidade. Rich Huxley (2010) ${ }^{63}$ afirmou: "se todos nós agora podemos fazer, distribuir e vender música, para ter sucesso temos de nos diferenciar da multidão e dar às pessoas algo que elas não podem obter em nenhum outro lugar. Se pudermos dar às pessoas algo que não seja repetível nem copiável, melhor. Então, o que é único e não-copiável? Um sentimento, ou uma experiência."

Com efeito, Hassenzahl (2011) pontua que a experiência é considerada um veículo para o marketing, e não necessariamente um produto próprio a ser vendido. Conforme o autor, a transição de uma economia de produtos e serviços para uma de experiência exige novas configurações e esforços, que vão além dos pensamentos mais recorrentes, pois para ele, experiência ou experiência do usuário não é sobre tecnologia, Design de produto, ou interfaces, mas sim sobre a criação de uma experiência significativa através de um dispositivo.

Ainda, diferente dos outros autores, Hassenzahl (2011) discorre mais longamente acerca do significado do termo experiência. Considerando-o um conceito rico, com uma longa história de debates e muitas tentativas de definição,

\footnotetext{
${ }^{62}$ A referência que o autor apresenta é The Experience Economy (Pine e Gilmore, 1999).

63 HUXLEY, Rich. Music is Not Our Currency, 2010. Disponível em: www.creativedeconstruction.com/2010/05/music-is-not-our-currency/ Data de acesso: 29 de maio de 2016
} 
o autor afirma que coloca seu foco primeiramente na ideia de experiência enquanto acontecimentos pessoais significativos (em alemão, Erlebnis), do que na concepção de conhecimento adquirido através desses acontecimentos (em alemão, Ehrfarung). As experiências consideradas pelo autor seriam, então, mais histórias de uso e consumo memorizadas do que a noção de imediatismo da experiência momento-amomento, como pode-se compreender a partir de Forlizzi e Battarbee (2004), texto aqui já trabalhado, pois ele considera que as experiências memorizadas têm mais relevância que aquelas imediatas. Com efeito, o autor questiona: mas o que existe em uma experiência? Psicologicamente, ele postula que uma experiência ocorre a partir da integração da percepção, da ação, da motivação e da cognição em um todo inseparável de sentido. Nesta direção, Hassenzahl (2011) argumenta por um entendimento da experiência como "um episódio, um pedaço de tempo que se passou, imagens e sons, sentimentos e pensamentos, motivos e ações estreitamente entrelaçados, armazenados na memória, rotulados, revividos e comunicados para os outros". Em suma, para o autor, a experiência é algo subjetivo, holístico, situado, dinâmico e interessante.

Por conseguinte, Hassenzahl (2011) põe-se a discutir a relação entre experiência e emoção, questão de relevância para a nossa discussão acerca da noção de experiência como mercadoria no Campo do Design. O autor considera que, i) porque uma experiência é constituída de um tecido complexo de sentimentos, pensamentos e ações, ela não prescinde de emoções e da satisfação de necessidades psicológicas universais; bem como que, ii) por serem as emoções também complexas, elas compartilham de medidas inerentes universais que propiciam estudos comparativos, os quais podem ser desenvolvidos para moldar comportamentos futuros. Deste modo, o autor dá o exemplo de uma jovem mulher que, em resposta a uma pesquisa sobre o relato de uma experiência recente e positiva mediada pela tecnologia, narrou o recebimento, logo cedo pela manhã, de uma mensagem de seu namorado em seu celular, dizendo "eu te amo". Ela estava viajando, eles estavam distantes e em horários diferentes, e tal atitude do namorado a fez sentir-se mais perto dele — ou, nos termos do autor, a jovem mulher teve uma experiência de aproximação, a qual tem significado positivo através da satisfação de uma necessidade social de relacionamento e intimidade. Entretanto, o autor enfatiza que o aparelho celular, neste caso, é apenas o instrumento para criar a experiência, já que a emoção positiva e seu significado é que correspondem à 
satisfação de uma necessidade psicológica universal. Logo, é a satisfação da necessidade o que faz uma experiência agradável. Com efeito, Hassenzahl (2011) destaca que uso e consumo são sempre traduzidos em uma experiência, uma história de uso, uma história de consumo e que, aparentemente, produtos e situações diferentes são representados num formato semelhante — o da experiência. Logo, o autor afirma que enquanto focarmos nas experiências criadas e moldadas por produtos interativos, pode ser difícil distinguir entre experiência do usuário e experiência em geral. Hassenzahl (2011) considera que experiência do usuário é apenas uma subcategoria da experiência em geral, com ênfase em um mediador específico, isto é, os produtos interativos; e que se queremos projetar para o Design de Experiência, então temos que ir além em uma distinção entre produtos interativos e outros mediadores de experiências.

Para retomar a questão do projeto de experiências em uma eventual cultura pós-materialista, Hassenzahl (2011) destaca que a ideia de um "produto interativo experiencial" [grifo nosso] aparenta uma contradição, pois enquanto a experiência é considerada intangível e volátil, o produto interativo é tangível, um artefato tecnológico produzido em massa. Por conseguinte, o autor afirma que até a “experiência pós-materialista" é, na maior parte das vezes, mediada por objetos físicos e que, por isso, devemos considerar que objetos, isto é, os produtos ou mercadorias, não são o oposto de experiências, mas sim as instâncias que as criam e substancialmente as moldam ou lhes servem de suporte. $\mathrm{O}$ autor menciona o exemplo de uma caneta e um pedaço de papel, que, mediando o resultado da atividade de escrita à mão, carregam características que acabam por moldar a experiência desta ação e sua consequente experiência. Logo, Hassenzahl (2011) afirma que, uma vez criada, a experiência é que consiste da propriedade que fica ao usuário - uma história imaterial e pessoal. Para o autor, o produto é, assim, apenas de interesse enquanto mediador da experiência.

Vislumbramos aqui como as definições de Design de Experiência intercambiam as vertentes teórica humanística e orientada pelo mercado supracitadas. Mas como, de fato, dá-se a prática projetual disso que os designers chamam de experiência? Passamos a esse estudo agora. 


\subsubsection{2.}

\section{Como projetar a/para a experiência?}

Faz-se imperativo agora verificarmos como os autores definem e descrevem a possibilidade de projetar a/para a experiência. Considerando a supracitada discussão acerca da dimensão do usuário nos projetos sobre experiência no Campo do Design - a eventual consideração deste não mais como sujeito, mas como objeto da prática no Campo - , almejamos agora apresentar e discutir as novas metodologias e processos surgidos para dar conta deste tipo de projeto, avaliar em que medida elas se diferem do que já era feito no Campo e em que medida entregam os resultados que prometem.

A $A I G A$, através da supracitada revista Gain (2000, p. 1), afirma que o designer que trabalha com projetos de experiência deve, além de dominar as habilidades tradicionais de designers, dialogar com virtuosos do mundo das Ciências Sociais, Economia, Arquitetura e Teatro, pois cada uma dessas disciplinas, antes consideradas distintas competências, hoje estão conjuntamente envolvidas no projeto da experiência de um consumidor através do uso de times interdisciplinares. Segundo a Associação, os profissionais devem fazer uso de habilidades que ampliam os conceitos de Design: estratégias de negócio, pesquisa sobre o usuário e marketing, ciências do comportamento, diagramação de processos criativos, Design de informação, Design de interação e storytelling - especialmente este, uma vez que a experiência é uma jornada ocorrendo através do tempo. Ainda, um atributo crítico de um eficaz projeto de Design de experiência consiste em utilizar técnicas do Design de informação para tornar o complexo simples. Conforme a revista, esta habilidade deve ser refletida, por exemplo, na clareza com que se descobre como navegar em um website ou em que se apresenta uma informação.

McLellan (2000, p. 64) também considera a proximidade da noção de Design de Experiência com a de estrutura de histórias como modelo de projeto para o Campo do Design. Afirmando que nós apreendemos melhor conceitos e modelos através de contos e exemplos que isoladamente, é com base na noção de que a experiência projetada pode ser uma história ou deve contar uma história que este modelo se sustenta - assim, as histórias seriam um elemento central para se projetar experiências. Com efeito, McLellan (2000, p. 64) cita Roger Schank 
$(1991)^{64}$, que diz que o grande problema não é nem o modelo, nem a consciência de uso deste modelo, mas sim “termos histórias melhores para contar". Logo, é a partir das histórias ou narrativas ${ }^{65}$ que McLellan (2000, p. 65) adentra a noção de tecnologia persuasiva, outro componente para a criação de experiências no Campo do Design. Segundo a autora, com base em Brian J. Fogg $(1999)^{66}$, a tecnologia persuasiva consiste de um sistema, dispositivo ou aplicação projetada para intencionalmente modificar as atitudes ou o comportamento de uma pessoa, de acordo com um modelo pré-determinado. Conforme Fogg (1999, p. 17), é justamente essa intencionalidade que diferencia o efeito colateral da tecnologia de seu plano traçado, pois a tecnologia persuasiva se organiza em três frentes: ferramentas (para aumentar habilidades), meios (para ocorrer a experiência), atores sociais (para criar relações); e ela pode ser tanto imposta (quando se trabalha em um local que exige a utilização), quanto eletiva (quando se escolhe trabalhar com ela).

Para complementar as diretrizes de como projetar experiências, a autora cita Byron Reeves e Clifford Nass (1996) ${ }^{67}$, que afirmam que pessoas automaticamente e inconscientemente respondem socialmente e naturalmente às mídias. De acordo com estes analistas, os humanos são experts em relações sociais e no funcionamento do mundo físico. Assim, a pesquisa de Reeves e Nass e a autora consideram que as mídias são percebidas como pessoas e locais, e que as respostas humanas às mídias são determinadas pelas regras que se aplicam às relações sociais. Logo, as regras de comportamento social promoveriam um grandioso conjunto de diretrizes para projetar experiências em que pessoas interagem com mídias. (MCLELLAN, 2000, p. 67)

Já Forlizzi e Ford (2000, p. 420), por considerarem que uma experiência é constituída por infinitas pequenas experiências, propõem dissecar uma experiência para entendê-la melhor, principalmente essa em acordo com seu contexto e as pessoas e produtos envolvidos. Um exemplo que dão para tal ato seria um

\footnotetext{
${ }^{64}$ SCHANK, Roger. Tell me a story: A new look at real and artificial memory. New York: 1991.

${ }^{65}$ A autora utiliza história e narrativa como sinônimos.

${ }^{66}$ FOGG, Brian J. Persuasive technologies. Communications of the ACM, 1999.

${ }^{67}$ REEVES, Byron; NASS, Clifford. The media equation. Cambridge, UK: Cambridge University Press, 1996.
} 
acampamento, em que temos a experiência de acampar como um todo sendo resultante das experiências menores de cozinhar, fazer trilhas, dormir em uma barraca e interagir com companheiros de viagem. Logo, as autoras afirmam que, na verdade, designers podem apenas projetar situações com as quais as pessoas podem interagir, ao invés de claros e previstos resultados — por conseguinte, os designers poderiam apenas projetar para uma experiência, e não $a$ experiência. Elas ainda afirmam que produtos possuem histórias de uso que requerem engajamento; entretanto, se o produto está fora do contexto para o qual ele foi projetado, ele pode ser utilizado de formas não previstas pelos designers, e isso pode ser relevante junto ao argumento do projeto de situações mais abertas, com resultados menos determinados.

Ainda quanto à dissecação, Forlizzi e Ford (2000, p. 420) indicam duas categorias a partir das quais compreender experiência, uma experiência, ou experiência como história: influências na experiência e qualidades da experiência. Sob influências, elas sustentam o entendimento dos componentes de uma interação usuário-produto $^{68}$ e o contexto desta interação: os usuários representam a forma como as pessoas influenciam a experiência, ao trazer suas experiências anteriores, emoções, valores e modelos cognitivos de entendimento; enquanto que os produtos representam como os artefatos influenciam a experiência, já que cada produto, de acordo com as autoras, tem uma história de uso de acordo com suas qualidades formais e sua acessibilidade. O contexto representa, então, os padrões social, cultural e organizacional em que a interação ocorre. Elas indicam que os designers devem estar cientes dessas relações para projetar corretamente. Já em relação às qualidades, as autoras discorrem prioritariamente sobre qualidades sensoriais referentes ao produto - como o produto é sentido pelas mãos, quão claramente é entendido seu funcionamento, como eles são compreendidos enquanto são utilizados, quão bem atendem ao seu propósito e o quanto eles se encaixam ao contexto em que são utilizados.

Por conseguinte, Forlizzi e Ford (2000, p. 421-422) passam para a apresentação de uma estrutura, um modelo para discutir experiência dentre designers. Esse modelo contém quatro componentes: subconsciente, cognição,

\footnotetext{
${ }^{68}$ Neste caso, temos também a variação usuário-produto (user-product) e humano-produto (humanproduct).
} 
narrativa e storytelling. ${ }^{69}$ Para subconsciente, as autoras consideram aquelas experiências mais automáticas e fluentes, que não exigem muito de nosso intelecto, como experiência rotineira do café da manhã, ler ou amarrar os sapatos. Já para cognição, as autoras consideram aquelas experiências que exigem que o pensamento acerca do que é feito tome a frente: a interação com produtos novos, a interação com produtos ou ambientes confusos que requeiram atenção e esforço cognitivo para um entendimento ou solução. Elas afirmam que este tipo de experiência é recorrente em dispositivos computacionais - entretanto, nem todas são experiências negativas. Já narrativas correspondem às experiências que já foram formalizadas na mente do usuário, como aquelas em que organizamos na linguagem ou em um artefato o que fazemos e experienciamos. As autoras afirmam que as instruções de uso de um produto oferecem uma narrativa, isto é, indicam como proceder para utilizá-lo. Por fim, o storytelling consistiria dos aspectos subjetivos de uma experiência - a pessoa salienta partes importantes da experiência e a transforma em uma história pessoal, de acordo com seu contexto, experiências anteriores e seu estado emocional momentâneo. Ainda, Forlizzi e Ford (2000, p. 422) discorrem sobre mudanças entre os componentes deste modelo: uma experiência poderia migrar do subconsciente para o cognitivo, por exemplo, quando algo inesperado ocorre em sua interação com o produto, forçando o usuário a pensar novamente, como programar um controle remoto, algo que não fazemos com recorrência e, então, temos de recorrer ao manual que foi pensado pelo designer, ou seja, o projeto do designer talvez não seja intuitivo. Com efeito, as autoras afirmam que designers podem usar esse modelo como ferramenta para direcionar a atenção a componentes particulares, a qualidades e efeitos de que cada um dos profissionais do time predispõe para a criação, além de variações de acordo com contexto e tempo.

Por sua vez, Suri (2003, p. 41-42) apresenta três frentes para o projeto para a experiência, não obstante enfatize as limitações de cada uma delas separadamente e, por isso, advogue pelo uso conjunto destas: i) compreender o que interessa; ii) explorar conceitos de Design; e iii) comunicar ideias experienciais. Sobre i) compreender o que interessa, a autora advoga pelo entendimento das qualidades que interessam para as pessoas e as maneiras como podemos potencializar essas

\footnotetext{
${ }^{69}$ No português brasileiro, o termo é adotado em inglês e seu significado é algo como uma narrativa, um contar uma história.
} 
qualidades, como compreender um grande espectro de atividades, pensamentos e sentimentos, aspirações, rituais e valores em distintos contextos pessoais, sociais, culturais e ecológicos, bem como processos e interrelações entre distintas qualidades, elementos e objetos nesses contextos, para então adquirir novas e mais completas informações para inspirar o projeto de Design. A autora informa que distintos métodos são utilizados, principalmente de fora do Campo do Design, como a etnografia, métodos cognitivos e análises de psicologia experimental, os quais auxiliam na compreensão objetiva de comportamentos e reações humanas de determinados cenários de Design. A autora ainda observa que, não obstante não seja possível ter a experiência do outro enquanto se projeta (SURI, 2003, p. 44), podemos encontrar meios de aproximarmo-nos e aprender de nossas próprias experiências como determinadas situações poderiam ser melhoradas ou projetadas. Quanto a ii) explorar conceitos de Design, a autora considera que se deve ir além dos métodos e processos já existentes no Campo, pois a investigação de ideias relativas às experiências de pessoas em um espectro físico, temporal e sociocultural mais amplo requer que ultrapassemos os limites dos modelos centrados em objetos tradicionais. Com efeito, ela afirma que há diferenças entre formas de representação para o aprendizado e a inventividade - formas tradicionais como esboço e prototipagem - e formas de representação para comunicar uma ideia a ser compartilhada com outros, pois estes últimos devem ser modelos mais dinâmicos e fluídos, que requerem ações, indo além de representações consideradas estáticas. Logo, Suri (2003, p. 45) considera que as novas formas de representação que estão surgindo, storyboards, cenários de usuários e vídeos, os quais são baseados na expressão da temporalidade, captam melhor as dimensões contextuais, o que permite o exame de ideias de forma mais dinâmica, contextualizada e multissensorial, provendo, assim, maior suporte para os projetos a serem desenvolvidos. Em iii) comunicar ideias experienciais, a autora advoga por times multidisciplinares - profissionais do Design de interação, Design Industrial, Engenharia, Arquitetura, Negócios, Marketing e Branding — trabalhando conjuntamente para melhor desenvolver e expressar ideias, trazendo perspectivas diferenciadas e únicas de acordo com cada expertise. Novamente, a autora menciona storyboards, vídeos e simulações em telas, além de demonstrações que façam os usuários ou pessoas em teste realmente experienciar a experiência enquanto essa está sendo pensada/ projetada, como o que é chamado de "protótipo 
de experiência." (SURI, 2003, p. 47) Ainda segundo a autora, a variedade do time multidisciplinar ajudaria na expressão de novas ideias e também na aprovação destas.

Forlizzi e Battarbee (2204, p. 262) discorrem sobre um modelo para a experiência centrado na interação, situado em um contexto social. O modelo é baseado em interações entre indivíduos e produtos e as experiências que resultam dessas interações. Além disso, ele indica a importância dessas experiências em um contexto de interação social, no qual pessoas interpretam acontecimentos de forma particular e, a partir disso, criam um significado. O modelo descreve interações usuário-produto: fluente, cognitiva e expressiva, e dimensões da experiência experiência, uma experiência e coexperiência. Não entraremos nos pormenores destas classificações, visto que são semelhantes ao já apresentado em Forlizzi e Ford (2000) — fluente corresponde à subconsciente; cognitiva se mantém e expressiva corresponde a uma soma de narrativa com storytelling -, salvo a coexperiência, antes não apresentada — anteriormente tínhamos a experiência como história. Para Forlizzi e Battarbee (2004, p. 263-264), a coexperiência consiste na experiência do usuário em contextos sociais. Ela ocorre quando experiências são criadas conjuntamente, ou compartilhadas com outras pessoas e, segundo as autoras, experiências compartilhadas permitem um grande espectro de interpretação por outros, do esperado e agradável ao incomum ou mesmo desviante, pois, conforme afirmam, as pessoas podem até mesmo rejeitar ou ignorar uma experiência. Logo, os significados são elaborados através da interação social. Exemplos: observar outras pessoas interagindo em uma exposição em um museu antes de interagir, procurar por uma câmera digital em uma loja com amigos, ou adotar maneirismos de amigos na escrita de mensagens virtuais. Com efeito, a coexperiência, segundo as autoras, revela como as experiências e a interpretação destas por um indivíduo são influenciadas pelos outros, tanto fisicamente quanto virtualmente.

Forlizzi e Battarbee (2004, p. 264-265), discorrem, ainda, sobre o que chamam de escalabilidade da experiência, ideia que já estava presente em Forlizzi e Ford (2000), mas que não havia ainda sido nomeada. Por escalabilidade da experiência, elas consideram a infinita quantidade de pequenas interações usuárioproduto e suas respostas emocionais a essas. Essas respostas variam de acordo com o contexto, pessoas envolvidas, objetivos e ações de um momento particular, os 
quais formam uma experiência maior ao longo do tempo. Essa experiência maior, por sua vez, também não consiste de acontecimentos singulares isolados, posto que esses se desdobram em relações com outras experiências e emoções. A escalabilidade, portanto, pode ajudar na construção de um panorama desde detalhes de interação de produto até histórias e significados que as pessoas articulam em suas experiências.

Pieter Desmet e Paul Hekkert (2007, p. $57-58)^{70}$ propõem um quadro geral para experiência do produto, o qual consideram passível de ser aplicado a todas as respostas afetivas que podem ser experienciadas em interações humano-produto. Eles partem de três componentes e níveis de experiência do produto já enunciados em Hekkert (2006): experiência estética, experiência de significado e experiência emocional, cada uma com seu sistema de leis. Segundo os autores, a noção de experiência do produto é utilizada para se referir a todas experiências afetivas possíveis envolvidas em interações humano-produto e a interação humano-produto pode dividir-se em instrumental, não-instrumental e não-física. Deste modo, a experiência seria moldada por características do usuário, como personalidade, habilidades, valores culturais e ambições; e características do produto, como forma, textura, cor e comportamento. Assim, todas as ações e processos envolvidos, como ações físicas e processos perceptivos e cognitivos - percepção, exploração, utilização, lembrança, comparação, entendimento - contribuem para a experiência. Em adição a isto tudo, o contexto, seja ele físico, social ou econômico, sempre acaba por influenciar a experiência. Os autores discorrem ainda sobre a teoria do núcleo afetivo, que consiste em uma maneira de organizar a experiência do produto, posto que todas as experiências possíveis envolvidas na interação humano-produto poderiam ser descritas em seus termos, desde o desagrado resultante da irritação face a uma falha no computador até a calma experiência de relaxar em um banho quente.

Logo, de acordo com os exemplos supracitados, os autores definem a experiência do produto como uma mudança no núcleo afetivo que é atribuída a uma interação humano-produto. Eles chamam a atenção para o uso do termo atribuído ao invés de causado, pois uma mudança no núcleo afetivo em virtude de uma causa particular é, por vezes, atribuída a uma outra causa errônea, imaginária. Assim,

70 DESMET, Pieter; HEKKERT, Paul. Framework of product experience. In.: International Journal of Design, v. 1, n. 1, 2007. 
Desmet e Hekkert (2007, p. 59) postulam que a experiência do produto se caracteriza como um fenômeno multifacetado, o qual envolve manifestações como sentimentos subjetivos, reações comportamentais, reações expressivas e reações fisiológicas. Com efeito, os autores complementam as diferenciações dos três níveis supracitados em relação ao artigo de Hekkert (2006): i) experiência estética: além das qualidades visuais, outras modalidades da estética do produto podem ser exploradas, como indicam Kees Overbeeke e Stephan Wensveen (2003) $)^{71}$, que utilizam o conceito de estética da interação para se referir à beleza de uso, ou seja, à beleza que se experimenta quando se interage fisicamente com um produto. Não obstante pertença ao nível estético da experiência, a concepção de estética da interação é reconhecida por se relacionar mais com aspectos táteis e sinestésicos que somente visuais; ii) experiência de significado: corresponde à cognição e seus processos, os quais são capazes de atribuir personalidade e outras características expressivas e avaliar o significado pessoal ou simbólico de produtos, embora reconheça-se aqui, também, a vulnerabilidade de um entendimento universal face a diferenças culturais e pessoais; iii) experiência emocional: consiste dos fenômenos afetivos tipicamente adotados na psicologia da emoção e no linguajar cotidiano sobre emoções, como amor e repulsa, medo e desejo, orgulho e desespero. Assim, uma compreensão do que chamaram experiência afetiva deverá contar com uma abordagem que explique como o comportamento, a cognição e a experiência em si estão inter-relacionados na experiência humano-produto.

Já McCarthy e Wright (2010, p. 24) advogam que a primeira questão a responder acerca da noção de Design de experiência seria como as pessoas que projetam Design centrado na Experiência descobrem as experiências que devem projetar? Conforme os autores, no tradicional Design centrado no Usuário, os designers descobrem sobre as necessidades dos usuários através de uma variedade de métodos de pesquisa, incluindo observação, entrevista, grupos focais, etnografia e assim por diante. Estas são suas ferramentas tradicionais e eles se baseiam nas disciplinas da Psicologia Social e das Ciências Sociais Aplicadas. Entretanto, quando o foco é sobre a experiência, como o uso desses métodos muda? Devemos empregar diferentes métodos? Como analisar os dados? Estes métodos são

\footnotetext{
${ }^{71}$ OVERBEEKE, Kees C. J.; WENSVEEN, Stephan A. G. Reflection on pleasure: From perception to experience, from affordances to irresistibles. In.: Proceedings of the DPPI03 Conference, ACM, 2003.
} 
adequados para questões de pesquisa sobre a experiência vivida e sentida? Os autores consideram que construir experiência está intimamente ligado à partilha de histórias e, nesse sentido, essa forma de pesquisa tem uma longa tradição que oferece um bom ponto de partida para conhecer as experiências das pessoas. A segunda pergunta a responder, segundo os autores, seria quais são as posições relativas da experiência, do designer e das pessoas para quem ele está projetando. Numa abordagem de engenharia tradicional, costuma-se considerar o usuário como o assunto de um inquérito de pesquisa e o designer como um coletor objetivo de dados que analise a vida de seus sujeitos da maneira mais científica possível. Contudo, seria este tipo de relacionamento eficaz para estudar a experiência e para fazer o Design centrado na experiência? A experiência deve ser descrita e analisada dessa forma objetiva? Seria o designer centrado na experiência um observador objetivo? Por fim, a terceira questão teria que responder quais são os compromissos e os valores que fundamentam e representam o Design centrado na Experiência e onde esperamos que eles nos levem no futuro.

Hassenzahl discorre em dois distintos momentos sobre o projeto de experiências: primeiro no livro Experience Design: technology for all the right reasons $(2010)^{72}$ e depois no supracitado User Experience and Experience Design (2011). Em 2010, o autor discorreu sobre a importância das emoções no projeto de uma experiência, afirmando que, embora as experiências reais possam ocorrer em um número infinito de variações, elas compartilham um núcleo comum e definidor — da mesma forma que as cadeiras variam, mas são reconhecidas como cadeiras. (HASSENZAHL, 2010, p. 57) Com efeito, o autor sugere que necessidades psicológicas universais, como competência, estimulação, relacionamentos, autonomia, popularidade, significado, segurança e esforço físico são constituintes importantes da experiência. Logo, seria o cumprimento dessas necessidades que geraria emoção e significado na interação com um produto. Assim, para satisfazer uma necessidade, um produto deveria ser instrumental, ou seja, capaz de criar ou moldar a experiência conforme desejado. Segundo Hassenzahl (2010, p. 57), as necessidades implicam ações instrumentais, que por sua vez implicam operações apropriadas; e somente se a ação é realmente instrumental, ou seja, se ela atende a

72 HASSENZAHL, Marc. Experience Design: technology for all the right reasons. Morgan \& Claypool, 2010. 
uma necessidade particular, surge uma experiência. Em outras palavras, a funcionalidade e a usabilidade são condições prévias necessárias para a realização da necessidade - ou seja, prazer — mas a funcionalidade e a facilidade de uso sem necessidades não têm sentido.

Já em 2011, o autor afirmou que o desafio de se projetar produtos para um mundo dito "pós-materialista" consiste justamente em trazer a experiência resultante à frente, ou seja, a experiência deve vir antes do produto. Em que consiste, então, projetar uma experiência? O autor discorre sobre a definição apresentada por Bill Buxton ${ }^{73}$, na qual o modo de uso, o como interagimos e nos sentimos ao interagir com um produto no momento em que é utilizado é o que importa. A concepção metodológica para o projeto de experiências de Hassenzahl (2011) distingue três níveis através da interação com um objeto, na seguinte ordem: por quê?, o que? e como?. Hekkert (2006) apresenta estrutura semelhante, quando indica pensar em por quê?, como? e o que?, mas coloca a maneira de experienciar ou de interagir com um produto antes da experiência ou da interação ou produto em si. Nos termos de Hassenzahl (2011), por quê? consiste da motivação de uso de um produto. No exemplo supracitado da jovem mulher e a mensagem de amor no celular, a mensagem não foi apenas uma mensagem, mas sim um recado amoroso, uma maneira de satisfazer a necessidade de ambos, ela e seu namorado, sentiremse próximos. Assim, afirma Hassenzahl (2011), um telefonema pode ser uma discussão de negócios, o fim de um relacionamento ou o pedido de uma pizza, pois as pessoas fazem ligações telefônicas por distintas motivações, e o telefone é apenas um instrumento, um mediador, mas não necessariamente um reflexo dessas necessidades e emoções. A pergunta $o$ que? corresponde às ações e atividades que as pessoas podem desenvolver através de um produto interativo, como fazer uma ligação, comprar um livro ou ouvir uma música, refletindo a funcionalidade e a tecnologia empregados em um produto. Já o como? está altamente interligado ao objeto e seu contexto de uso, bem como à ação através do objeto a partir de um modo operacional, motor. O autor ressalta ainda que o como? corresponde exatamente à atividade do designer de interação: fazer dada funcionalidade acessível de uma forma esteticamente agradável. Hassenzahl (2011) dá um

\footnotetext{
${ }^{73}$ BUXTON, Bill. Sketching User Experiences: Getting the Design Right and the Right Design. Morgan Kaufmann, 2007.
} 
exemplo: fazer uma ligação (um o que?) requer uma série de ações — selecionar uma pessoa para quem ligar, procurar pelo número no celular, inicializar e, posteriormente, finalizar a chamada. Como isto é feito em determinado objeto aqui, o celular - é especificado por um designer de interação, e essas ações podem variar em qualidade estética de aparelho para aparelho. Com efeito, o autor menciona que o o que? e o como? são hoje considerados o produto em si, e que uma interação estética, nova e estimulante é o que torna esse produto experiencial. Deste modo, Hassenzahl (2011) afirma que, ao inicializar um produto pelo por $q u e ̂$, pela clarificação das motivações e emoções humanas envolvidas em determinada atividade e somente posteriormente determinar a funcionalidade capaz de promover aquela experiência ( $o$ que?) e o modo apropriado de colocar esta funcionalidade em uso (como?), o designer traz a experiência e a emoção à frente, para serem elas as responsáveis por ditar como tal ação deve se dar. Consequentemente, o autor afirma que tal modus operandi resulta em produtos que são sensíveis às particularidades da experiência humana, produtos capazes de promover histórias agradáveis através de seu uso ou consumo.

Vimos como os designers pensam e estruturam o projeto de/para experiências. Na verdade, o que é apresentado não parece configurar metodologias ou estruturas de projetos específicas ao Design de Experiência, mas sim contínuas tentativas de justificar a sua necessidade e sua definição, como, por exemplo, a separação de Forlizzi e Ford (2000, p. 420) em experiência, uma experiência e experiência como história. Isso parece se dar pelo fato de que, como afirma Redström (2006, p. 123-124), talvez os designers queiram projetar algo que não está aí para ser projetado - e neste sentido, caso o leitor aponte a preocupação com o usuário como um diferencial, Redström (2006, p. 127) também nos lembra que, em última instância, o usuário como objeto recairá ainda em uma impossibilidade efetiva de projeto, sobretudo pelo simples fato de que não pode haver usuários de coisas que não existem. Deste modo, resta-nos agora investigar como se avaliam e quais são os resultados destes projetos ditos de/para a experiência. 


\subsubsection{3.}

\section{Avaliações e resultados experienciais}

São poucos os textos que tratam das avaliações e resultados de projetos de experiência, isto é, que investigam se esses projetos de fato cumprem com o que prometem entregar ou proporcionar ao usuário ou cliente. Mitchell (1993) e Redström (2005) discorrem sobre projetos que não deram certo e sobre como essa promessa não cumprida teria ocasionado mudanças nas concepções e metodologias no Campo do Design. Mesmo com projetos digitais, que são retroalimentados e atualizados com frequência com o intuito de proporcionar melhorias, ainda são poucos os estudos que abordam a entrega e o uso dos produtos desenvolvidos pelo Campo do Design, sejam esses digitais ou físicos. Assim, faz-se relevante agora visualizarmos e discutirmos algumas parcas considerações acerca desta dimensão final muito esquecida em pesquisas e no cotidiano da prática do Campo do Design.

McLellan (2000, p. 68-69) aborda a necessidade de uma experiência positiva e memorável em interfaces, principalmente considerando interações e feedbacks. Citando Patricia Seybold $(1998)^{74}$, ela indica oito fatores para o sucesso de um comércio eletrônico, como a Amazon: 1) ter como alvo os consumidores corretos; 2) deter toda a experiência, todo o processo de navegação; 3 ) agilizar os processos de negócios que impactam o cliente; 4) promover uma completa visualização da relação com o consumidor; 5) deixar o consumidor agir por si próprio; 6) deixar o consumidor fazer sua parte; 7) entregar serviços personalizados; e 8) propiciar um sentimento de comunidade. Com efeito, personalizar - ou customizar, nos termos de Pine e Gilmore (2013) — um negócio poderia ser uma boa saída, segundo a autora, pois os consumidores gostam de ter uma experiência bem orquestrada e bem projetada, com o sentimento de pertencimento, de proximidade. Contraditoriamente, eles também querem ser capazes de modelar sua própria experiência, para que essa se encaixe em suas circunstâncias individuais. Segundo Seybold (1998, p. 100), os consumidores só ficariam totalmente satisfeitos com um tratamento que considerassem individual então teríamos a experiência total ou ideal. Assim, o trabalho do Design de Experiência seria orquestrar as tecnologias em uso com seus entendimentos e seu sentido social na vida dos usuários, fazendo este equilíbrio entre algo padrão e a

\footnotetext{
${ }^{74}$ SEYBOLD, Patricia. Customers.com. New York: Times Business, 1998.
} 
possibilidade do individual. Isto poderia ser alcançado, segundo McLellan (2000, p. 69), através dos modelos e exemplos que incluem práticas e estudos não apenas do Campo do Design, mas também da Economia, Psicologia, Sociologia, Comunicação, Teatro e Computação, relação já abordada na seção anterior.

Já Forlizzi e Ford (2000, p. 423) afirmam que, ao coletar e compreender experiências subjetivas de usuários e sintetizá-las na construção de uma narrativa formalizada em um produto, designers podem criar produtos e experiências benéficas, utilizando a experiência como fonte de informação para produtos que melhorem nossas qualidades de vida. As autoras ainda advogam que talvez eventualmente os designers possam vir a ajudar as pessoas a compreender suas próprias experiências e a transformá-las em produtos que carreguem valores pessoais e sociais.

Shedroff (2001, p. 160) discorre sobre o controle das experiências. O autor afirma que as pessoas esperam que tenhamos certo controle sobre suas experiências, pois isso as faz sentir confortáveis e respeitadas. Este controle poderia consistir tanto no ritmo da interação, na sequência dos passos, no tipo de ação ou qualidades, quanto até mesmo no retorno desejado. Ele ainda defende que a única forma de saber quanto controle é importante é questionar os participantes sobre suas necessidades e desejos e, posteriormente, testar as experiências para ver como elas funcionam.

Já Todd Cherkasky (2003, p. 10) $)^{75}$ argumenta que as estruturas de instituições organizacionais e linhas de autoridade em que o Campo do Design está inserido e em que sua prática ocorre restringem e habilitam os processos de Design e seus resultados. Logo, o autor postula que essas instituições e linhas determinam quem é participante legítimo, cujas expertises são valorizadas, e quem deve ser deixado de fora. Ainda, os recursos simbólicos que englobam representações de e sobre o Design, incluindo como problemas de Design são formulados, como resultados são avaliados, e como as narrativas são pensadas, são também determinados por esses participantes legítimos e, por isso, constituem escolhas e padrões arbitrários de avaliação, ainda que sejam parte de uma técnica com parâmetros, por exemplo.

75 CHERKASKY, Todd. Designing Experience. In.: International Journal of Engineering Education. Vol. 19, No. 1, 2003. 
Em um segundo momento, o autor afirma que a extensão para qual soluções de problemas são percebidas como bem-sucedidas é um resultado, em parte, das métricas usadas para avaliá-las. Com efeito, diante de contextos de fins lucrativos, Cherkasky (2003, p. 13) estabelece que o chamado retorno sobre o investimento (ROI) constitui uma chave métrica, e postula que um desafio significativo para os defensores do Design da Experiência do Usuário nesses contextos é identificar como representar o valor da experiência. Pesquisas de opinião, análise de arquivo de registro, software de data mining e software de usabilidade constituem instâncias que fornecem algumas medidas de experiência do usuário. Outras técnicas, estas menos acessíveis a análises quantitativas, são testes de protótipo no local e avaliações em contexto. $\mathrm{O}$ autor continua afirmando que cada uma dessas métricas enfatiza diferentes aspectos da experiência do usuário: arquivos de log e testes de usabilidade, por exemplo, acompanham tarefas concluídas, já avaliações em contexto fornecem informações sobre as motivações dos usuários. O autor considera ainda que, do início à conclusão do projeto, representações do Design desempenham um papel importante. Ao garantir que os problemas de Design sejam formulados com os usuários em mente e que as métricas avaliem o que é importante para as pessoas no contexto de uso, os designers e diversos profissionais envolvidos poderiam orientar a prática do projeto para soluções que melhorem a experiência dos usuários.

Com efeito, por sua obstinação, forma e composição, Cherkasky (2003, p. 13) considera que essas técnicas moldam as relações sociais e simbolicamente expressam significados sociais. $\mathrm{O}$ autor considera que analisando como os recursos materiais são configurados no contexto de uso - identificando quais práticas sociais eles facilitam e/ou restringem - ajuda a rastrear os valores e os pressupostos de projeto à medida que estes se incorporam em ferramentas, máquinas, sistemas e espaços.

McCarthy e Wright (2010, p. 24) consideram que o estudo das emoções relacionadas ao produto está ganhando popularidade, mas a principal diferença entre estudá-los e estudar a experiência do usuário é que os estudos sobre a emoção tratam os processos de criação de significado como um problema, porque distorcem o relato de emoções. No entanto, os autores postulam que não é possível descrever experiências sem esses processos. Com efeito, o estudo e a definição de emoções frequentemente seguem um tipo de modelo de estímulo-resposta que não leva em 
conta a forma como as emoções são interpretadas e modificadas em situações sociais, nem como são usadas estrategicamente como um recurso na interação social. Logo, ao estudar a experiência do usuário, o foco deve ser no mundo de acordo com os usuários, não de acordo com os designers, os críticos profissionais e os fabricantes de produtos.

Ainda, Wright et al $(2008 \text {, p. } 2)^{76}$, inclinando-se sobre a estética pragmática de John Dewey (1980) e Richard Shusterman (2000) ${ }^{77}$, desenvolvem uma estrutura para entender a estética como uma perspectiva complementar adicional sobre o Design centrado no Usuário. Eles fazem uma distinção entre a estética analítica e a estética pragmática. Em termos gerais, uma abordagem analítica da estética concentra-se no artefato e o valor de seus atributos perceptíveis independentes de qualquer contexto sócio-histórico e independente do usuário. Em contrapartida, o pragmatismo vê a estética como um tipo particular de experiência que surge na interação entre usuário, contexto, cultura e história, e não deve ser vista exclusivamente como uma característica do artefato ou do usuário. Em vez disso, ela surge na construção de relações entre artefatos e espectadores, assunto e objeto, usuário e ferramenta. Com efeito, os autores postulam que uma premissa pragmatista fundamental que emerge do envolvimento contínuo corresponde a um encontro que é tanto sobre o que a pessoa traz para a experiência como sobre o que ela encontra lá. Logo, Wright et al $(2008$, p.7) afirmam que a capacidade de não apenas compartilhar experiências, mas criá-las, faz-se possível. Assim, o que os designers podem fazer é fornecer recursos através dos quais os usuários possam estruturar suas experiências.

Já Jung-Joo Lee $\left(2009\right.$, p. 39) ${ }^{78}$ critica, por exemplo, a falta de um viés que considere variações culturais no desenvolvimento e avaliação de projetos de interação. A autora afirma que mesmo que a literatura em Antropologia Cultural e

\footnotetext{
${ }^{76}$ WRIGHT, Peter; WALLACE, Jayne; and MCCARTHY, John. Aesthetics and experiencecentered design. In.: ACM Transactions on Computer-Human Interaction, Vol. 15, No. 4, Article 18, November 2008.

77 SHUSTERMAN, Richard. Pragmatist Aesthetics: Living Beauty, Rethinking Art, 2nd ed. Rowman and Littlefield, Boston, MA, 2000.

${ }^{78}$ LEE, Jung-Joo. Culture and Co-experience: Cultural Variation of User Experience in Social Interaction and Its Implications for Interaction Design. In.: Aykin N. (eds) Internationalization, Design and Global Development. IDGD 2009. Lecture Notes in Computer Science, vol 5623. Springer, Berlin, Heidelberg, 2009.
} 
Psicologia Cognitiva implique influência cultural na experiência do usuário na interação social, uma noção transcultural, no entanto, tem sido negligenciada nesta área. Ela postula que mudanças sociais acarretam mudanças de padrões e que, neste sentido, o viés cultural se faz necessário.

Por fim, Demir (2008, p. 140) considera que designers têm poder limitado para influenciar as atividades particulares dos usuários: eles não podem — e não deveriam - ditar uma experiência particular, assim como eles não podem ditar um comportamento particular. Conforme o autor, cada produto projetado serve a uma função particular e o produto, assumindo que a intenção é genuína, é projetado para propiciar uma função pretendida e as maneiras de utilizá-lo através de sua semântica. Entretanto, Demir (2008, p. 140-141) afirma que produtos são adotados no dia-a-dia dos usuários em ressonância com suas expectativas diárias e seus desejos, de maneiras diferentes, desencadeando distintas funções e imprevisíveis formas de uso do produto, o que ocorre também ao se projetar para as ditas "respostas emocionais e afetivas", as quais são dependentes variáveis situacionais e contextuais e das preocupações ativas e latentes dos usuários e, portanto, "situadas". Não obstante os trabalhos em afetos e emoções identifiquem processos universais subjacentes como processos de avaliação, ele considera que o input básico desses processos são as preocupações dos usuários, algumas das quais são inatas e outras que são adquiridas e sujeitas a influências temporais e culturais.

$\mathrm{O}$ autor postula que outro argumento proeminente e importante para moldar as atividades de pesquisa em Design e Emoção é o sucesso de mercado. É comumente afirmado que consumidores pedem por mais e que as emoções dos consumidores são fatores de influência no contexto de compras. Como consequência, Demir (2008, p. 142) aponta que algumas das atividades de pesquisa em Design e Emoção se concentram em respostas emocionais que podem ter impacto nas decisões de compra e trazer sucesso de mercado. O ponto que deve ser esclarecido é que o argumento do sucesso de mercado pode contradizer a visão humanista de projetar produtos com um significado emocional e um relacionamento sustentado. O autor afirma que Aren Kurtgözü (2003, p. 57) $)^{79}$ considera que produtos direcionados às emoções do consumidor podem “[...] ser manufaturados

\footnotetext{
${ }^{79}$ KURTGÖZÜ, Aren E. From Function to Emotion: A Critical Essay on the History of Design
} Arguments. In.: The Design Journal, 6(2), 2003. 
e calculados em relação ao lucro em vez de surgir originalmente da autêntica vida individual e comunitária". Neste sentido, Kurtgözü também aponta para o perigo de focar nas paixões dos consumidores através da adição de brilhos superficiais nos produtos, e afirma que o marketing desses brilhos como "necessidades" emocionais é essencialmente uma mercantilização/comoditização de emoções e experiências. Com efeito, as abordagens orientadas para o mercado podem ver a emoção como um fim a ser alcançado por si mesma. Ainda, Kurtgözü (2003, p. 57) afirma que esse processo de comoditização de emoções e experiências reforça a cultura do consumo na qual novas experiências devem ser geradas para substituir as antigas que perderam seu charme e, por isso encontram-se longe do objetivo pretendido de oferecer relacionamentos significativos e evocativos.

Erdem (2008, p. 147) afirma que em virtude, parcialmente, da natureza dessas ferramentas que objetivam suscitar respostas afetivas em um ambiente controlado, não se sabe ao certo se os produtos projetados através de tal atividade de engenharia emocional criarão a resposta prevista em situações da vida real e sobre encontros repetidos. A agenda de pesquisa do Campo do Design e Emoção deveria, portanto, expandir para incluir relações entre experimentos laboratoriais e experiências de vida diária de usuários, para que ferramentas e métodos que preveem as respostas da vida diária dos usuários possam ser mais corretamente desenvolvidas.

Por fim, retornamos aos escritos de Cherkasky (2003, p. 9), que explicita uma condição com a qual concordamos: "Eu sou reticente, entretanto, ao afirmar que o que fazemos é realmente projetar a experiência das pessoas. Afinal, as pessoas têm experiências. Nós projetamos para elas. Quão bem os designers compreenderam a experiência daqueles que usarão os sistemas que eles implementarão? Além do mais, quão bem eles compreendem a sua própria [grifo nosso] experiência de Design?"

Como vimos, a definição de experiência no Campo do Design não conta com um único direcionamento. Há aqueles que postulam que podemos projetar a experiência, outros para a experiência, e outros que negam esta possibilidade. Hassenzahl (2010) afirma que o problema com o termo experiência no Campo do Design é a falta de uma definição apropriada ou pelo menos amplamente reconhecida. Definir a experiência - como é evidente na literatura - é difícil por sua natureza dinâmica, até paradoxal. Se, por um lado, a experiência é considerada 
privada, única e individual, por outro, ela parece só fazer sentido no meio social, isto é, de acordo com diretrizes coletivas. Deste modo, partiremos agora para uma ampliação do nosso entendimento da noção de experiência. Ao irmos além-Campo do Design - neste caso, para escritos do Campo da Filosofia — pretendemos buscar subsídios para uma luz crítica e social acerca das definições tecnológicas e mercadológicas que imperam no Campo do Design.

\section{2}

\section{Variações sobre um tema universal}

Experiência é um termo com peso histórico. A compreensão que temos dele hoje, sobretudo no Campo do Design, é diferente do seu significado ao longo da história do pensamento humano. Homens e mulheres de distintos períodos — da Idade Antiga à Idade Média, Moderna e Contemporânea - formularam seus conceitos de experiência a partir das condições materiais e intelectuais vigentes. Por mais que nestas condições estejam abarcados os variados níveis de uso de tecnologia em cada uma dessas épocas - e assim, criticar a experiência hoje como determinada tecnologicamente parece não fecundar um novo pensamento, pois em outros momentos os entendimentos de experiência também tiveram relação com o que a tecnologia e as condições materiais propiciavam experienciar sujeitos dessas experiências com a tecnologia é que atingiram patamares mais intensos $^{80}$ e, por isso, precisam ser investigadas. Antes de partir para essa investigação, entretanto, precisamos compreender por que iniciamos esse subcapítulo afirmando o conteúdo da primeira frase. Martin Jay, em sua obra Songs of Experience: modern american and european variations on a universal theme $e^{81}$ (2006) - cujo subtítulo adotamos para nomear esta parte do nosso estudo em semelhante homenagem à que ele presta à obra de William Blake, Songs of

\footnotetext{
${ }^{80}$ Adam Greenfield, em Radical Technologies (2017), discute a quase onipresença da tecnologia no cotidiano hoje. Ver: GREENFIELD, Adam. Radical Technologies: the Design of everyday life. Verso, 2017. Aqui lembramos também da noção de desaparecimento da tecnologia já vista na primeira parte deste capítulo.

81 JAY, Martin. Songs of Experience: Modern American and European Variations on a Universal Theme. University of California Press, 2006.
} 
Innocence and of Experience: showing the two contrary states of the human soul ${ }^{82}$ (1789) —, afirma que, por ser experiência um termo da linguagem cotidiana, seu entendimento desempenhou e desempenha um importante papel em praticamente todo o pensamento humano sistemático, proporcionando uma rica veia de investigação filosófica - sobretudo a continental, seu ponto de investigação desde os gregos. Logo, ao discorrer sobre a noção de experiência desde o pensamento grego, passando pelo medievo, a modernidade - que modaliza a experiência em distintas categorias, como a religião, a estética, a política e a história — até a contemporaneidade, Jay (2006) define, descreve e discute a complexidade do termo em questão.

É neste sentido que investigaremos agora algumas outras acepções do termo experiência, com vias a uma ampliação do entendimento empregado pelo Campo do Design, uma vez que este parece compreendê-lo como anistórico, como algo natural, dado, de sentido fixo, não cambiante, que simplesmente ocorre porque somos humanos, e o qual o Campo do Design pode ajudar a "melhorar". Entretanto, não é nosso objetivo aqui traçar uma ideia totalizadora, que assuma um ponto de vista unificado do entendimento do termo experiência: antes, interessa-nos compreendê-lo a partir de seu uso histórico, dinâmico e variado, que é sempre político, isto é, depende das forças sociais, daquilo que discutem e daquilo que arbitrariamente acabam escolhendo. Assim, que condições da vida material propiciaram as mudanças de entendimento da noção de experiência que veremos a seguir? Não utilizaremos em pormenores todo o conteúdo do livro de Jay, visto que não é nosso propósito — nem de nossa capacidade — adentrar querelas filosóficas específicas. O que desejamos salientar a partir dos escritos e da incansável investigação desse autor é a complexidade e a pluralidade das tentativas de definições do termo, bem como a discussão de seus pressupostos, o que nos torna aptos a questionar então as definições empregadas no Campo do Design. Diante do universo de autores apresentados por Jay que trataram da noção de experiência, selecionamos para discutir neste subcapítulo aqueles que: i) já foram mencionados nos escritos do Campo do Design sobre a noção de experiência; ii) julgamos auxiliar-nos no entendimento da experiência como mercadoria. Salientamos aqui

\footnotetext{
${ }^{82}$ BLAKE, William. Songs of Innocence and of Experience: showing the two contrary states of the human soul. Oxford University Press, 1967.
} 
que trabalharemos com uma síntese das ideias principais acerca da noção de experiência desses autores e que, portanto, pontos de aprofundamento, detalhes que potencialmente enriqueceriam a crítica nos pormenores de cada autor estão no futuro, visto que a investigação não se esgota no que abordamos. Deste modo, principiamos por uma breve discussão etimológica, a fim de evidenciar a origem e os desdobramentos semânticos do termo ao longo do pensamento humano. Em seguida, partimos para o entendimento da noção de experiência estética, abordando especialmente o pensamento de John Dewey, com o qual já nos deparamos em muitos escritos do Campo do Design. Após, faremos o movimento para a Escola de Frankfurt, buscando compreender a partir dos escritos de Walter Benjamin e Theodor Adorno o que foi denominado "crise da experiência", uma lamentação com fortes laços às atribulações do modo de produção capitalista e, consequentemente, à posição da experiência como mercadoria, cerne deste estudo. Por fim, a partir do pensamento político de Raymond Williams e dos escritos históricos de Joan Scott, discutiremos as bases do que foi chamando linguistic turn, a virada linguística, que questionou a autoridade da experiência através de uma investigação da formação do sujeito, ao qual, conforme Čargonja ${ }^{83}$ (2011, p. 293), a noção de experiência está vinculada durante todo seu caminho de amadurecimento. Os questionamentos que Jay (2006, p. 4) coloca à sua investigação interrogam: quando e por que o termo experiência ganhou autoridade fundamentalista? A que a invocação do termo experiência é uma resposta? Sob quais circunstâncias essa invocação perde seu poder? Essas perguntas nos guiarão também em nossas investigações no Campo do Design.

\footnotetext{
${ }^{83}$ ČARGONJA, Hrvoje. Ambiguous Experience: A Contribution to Understanding Experience as Discourse. Stud. ethnol. Croat., vol. 23, str. 283-308, Zagreb, 2011. O estudo da noção de experiência transpassa a formação histórica da subjetividade. Aqui não trataremos deste tema em seus pormenores, visto que uma devida atenção configuraria um outro trabalho, mas trataremos das partes que tangenciam as bases teóricas para aplicação ao uso do termo contemporaneamente no Campo do Design.
} 


\subsection{1.}

\section{Etimologia}

Tentar "gerenciar" uma palavra como experiência é uma atitude perigosa, afirma Jay $(2006$, p. 10), pois importa uma singularidade rígida e atemporal ao que precisamente deve ser reconhecido como variado e temporalmente definido. Deste modo, não obstante considerando que não podemos recuperar um verdadeiro ponto de origem linguística - grego, hebraico ou latim e suas línguas ainda anteriores , faz-se útil vislumbrar agora os significados sedimentados que já foram adotados para o termo experiência, uma vez que a reflexão sobre estes pode conduzir-nos a formular um entendimento mais amplo da sua condição atual, ou seja, da experiência enquanto mercadoria no Campo do Design.

Jay (2006, p. 10) inicia seu estudo etimológico pela palavra inglesa experience, derivada do latim experientia, a qual denota julgamento, prova ou experimento. Já o francês expérience e o italiano esperienza podem significar um experimento científico, quando na forma indefinida. Tentar (expereri, em latim) contém a mesma raiz do também latim periculum, ou perigo, o que sugere que experiência pode significar ainda sobreviver a riscos e ter aprendido algo. $\mathrm{O}$ antecedente grego, por sua vez, é empeiria, que é também a raiz da palavra inglesa empirical (empírico), algo aprendido pela observação. Jay (2006, p. 10-11) afirma que uma das escolas de medicina gregas, que se baseava em observação em vez de autoridade ou teoria, era chamada de Empiriki e se opunha às facções concorrentes conhecidas como Dogmatiki e Methodiki. Assim, podemos observar um vínculo crucial entre experiência e sensação crua, não refletida, ou observação não mediada, como oposição à razão, à teoria ou à especulação. Semelhante também é a associação de experiência com assuntos específicos em detrimento de gerais, com detalhes em vez de universais, e essa associação contribui para a crença, em certos usos, de que as experiências são pessoais e incomunicáveis, em vez de coletivas e intercambiáveis. O autor cita ainda outra palavra grega, pathos, que pode ser incluída entre os antecedentes do conceito moderno, mesmo que o vínculo etimológico esteja ausente. Pathos significa basicamente algo que acontece no sentido do que sofre ou perdura, ou seja, um momento passivo ou o reconhecimento de que as experiências podem ocorrer sem ser procuradas ou desejadas. 
O alemão, por sua vez, exige especial atenção, posto que os termos utilizados para experiência, Erlebnis e Erfahrung, têm carga teórica - veremos o emprego destes, sobretudo, nas considerações acerca da Escola de Frankfurt. Jay (2006, p. 11-12) afirma que ambos Erlebnis e Erfahrung são empregados para experiência, mas implicam noções muito diferentes. Erlebnis contém a raiz da palavra vida (Leben) e por vezes é traduzido como experiência vivida; e embora erleben seja um verbo transitivo e implique uma experiência de alguma coisa, o substantivo Erlebnis é frequentemente entendido como uma unidade primitiva antes de qualquer diferenciação ou objetivação. Ainda, normalmente localizado no "mundo do cotidiano" (o Lebenswelt), um mundo de práticas comuns e não teóricas, Erlebnis também pode sugerir uma ruptura intensa e vital no tecido da rotina cotidiana, correspondendo a uma experiência mais imediata, pré-reflexiva e pessoal. Já Erfahrung, segundo Jay (2006, p. 11-12), é comumente associada a impressões externas, sensoriais ou a julgamentos cognitivos sobre eles (especialmente na tradição associada a Immanuel Kant), bem como a uma noção de experiência baseada em um processo de aprendizado, temporariamente mais alongada e em um todo narrativo ou uma aventura. Esta concepção, que por vezes é chamada também de noção dialética da experiência, converte um movimento progressivo, ao longo do tempo, o que está implícito no Fahrt (jornada) embutido em Erfahrung e a ligação com a palavra alemã para perigo (Gefahr). Com efeito, Erfahrung ativa ainda um vínculo entre memória e experiência, o que subentende a crença de que a experiência cumulativa pode produzir uma espécie de sabedoria que vem apenas ao final do dia. Não obstante não seja regra, Erlebnis geralmente sugere individualidade, enquanto que Erfahrung pode ter um caráter público e coletivo - contudo, é possível ver as variantes de ambas invocadas de maneira oposta. No Campo do Design, parece que o uso da noção de experiência intercambia entre Erlebnis, quando de seu entendimento individual e autêntico, e Erfahrung, quando de sua ocorrência como algo com regularidade no uso de novas tecnologias. Apenas três autores, Hassenzahl (2011) e, posteriormente, Pine e Gilmore (2013), na atualização de Welcome to the Experience Economy, fizeram alusão a esta diferenciação na língua alemã.

Jay (2006, p. 12) afirma ainda que se a evidência etimológica sugere alguma coisa, é que experiência é um termo repleto de significados sedimentados que podem ser atualizados para uma variedade de propósitos diferentes e justapostos a 
uma outra variedade de antônimos. Consequentemente, isso permite tanto a lamentação de que a experiência (em um dos sentidos de Erfahrung) já não é possível, quanto a afirmação aparentemente contraditória de que agora vivemos em uma verdadeira "sociedade da experiência" (Erlebnisgesellschaft), termo empregado por Gerhard Schulze em 1992, no supracitado livro Die Erlebnisgesllschaft: Kultursoziologie der Gegenwart. Tal possibilidade de entendimento nos permite também tanto "atrair" a experiência, como se fosse sempre uma coisa no passado, quanto "ter fome de experiência", como se fosse algo que se poderia desfrutar no futuro. Ainda conforme o autor, tal possibilidade permite uma distinção entre o substantivo experiência como algo que se pode "ter" ou "ter aprendido com" e o verbo ou o processo de "experienciar", o último sugerindo o que alguém agora está "fazendo" ou "sentindo". Ora, produzir um conhecimento específico, uma habilidade ou perícia em algo ou alguma coisa, por intermédio de um aprendizado sistemático que se aprimora com o tempo, típico do exercício prático, é a pedra de toque disso que os pares do campo chamam prática do Design ${ }^{84}$ Ademais, porque pode abranger tanto o que está sendo experienciado quanto o processo do sujeito de experienciá-lo, a palavra às vezes pode funcionar como um termo guarda-chuva para superar o deslizamento epistemológico entre sujeito e objeto. Jay (2006, p. 12) ainda afirma que se acrescentamos a possibilidade de adjetivos modificadores independentes, como vivido, interior e genuíno, tornase fácil compreender por que o termo teve uma história tão plural e continua a exercer controle sobre a nossa imaginação.

Por fim, podemos ainda adicionar aqui a definição presente na edição eletrônica de 2009 do Dicionário Houaiss. ${ }^{85}$ Nela, define-se experiência como um substantivo feminino que corresponde ao ato ou efeito de experimentar(-se), experimentação, experimento (método científico), como, por exemplo, um experimento químico. Quanto ao sentido filosófico, o Dicionário indica qualquer conhecimento obtido por meio dos sentidos, uma forma de conhecimento abrangente, não organizado, ou de sabedoria adquirida de maneira espontânea

\footnotetext{
${ }^{84}$ É recorrente entre os pares do Campo do Design a afirmação de que "design se faz fazendo", que sua prática profissional é presidida pelo axioma "mãos na massa", pois trata-se de um saber prático.

${ }^{85}$ Houaiss 3.0, junho de 2009. Instituto Antônio Houaiss. Produzido e distribuído pela Editora Objetiva Ltda.
} 
durante a vida, como, por exemplo, "viveu muito, tem muita experiência." Há ainda o entendimento de forma de conhecimento específico, ou de perícia, que, adquirida por meio de aprendizado sistemático, se aprimora com o correr do tempo, com a prática, como, por exemplo, "pugilista de muita experiência”. Por fím, tentativa, ensaio, prova, como em "resolveu fazer uma experiência apostando nos números pares." Conseguimos enxergar essas definições no Campo do Design? E fora dele?

\subsection{2.}

\section{A experiência estética e o Pragmatismo}

Antes de começar a discutir a experiência estética, Jay (2006, p. 261) discorre sobre uma substancial mudança na forma de pensar que ocorre a partir da Idade Moderna, mais precisamente a partir do Iluminismo: a separação do conhecimento humano em distintas disciplinas. Fraturando o que antes era uno ${ }^{86}$ em subcategorias que, no exemplo da experiência, correspondem à Epistemologia, Religião, Estética, Política e História - divisão esta que equivale à organização dos capítulos do seu livro , o autor arrazoa sobre a forma como a lógica inerente de cada variante isolada ajudou a esclarecer e a construir a complexidade da noção do termo em questão. Ele ainda adverte que mais do que simples distinções categóricas, essas noções de experiência diferenciadas também funcionaram politicamente como guias normativos para práticas sancionadas pelas instituições sociais e culturais que surgiram com a finalidade de propagá-las e regulá-las —, ocorrência que podemos vislumbrar até hoje, sobretudo com a adoção do termo pelo Campo do Design.

Ao iniciar a discussão estética propriamente dita, Jay (2006, p. 167-168) postula que dois fatores propiciaram o desenvolvimento de uma variante da experiência especificamente estética: a perda da fé em um mundo inteligível de

\footnotetext{
${ }^{86}$ Jay afirma que antes da Idade Moderna não havia uma categorização clara como a que começa a ser adotada a partir deste período. Para exemplificar os tratamentos anteriores da experiência, além do indicativo etimológico já apresentado, ele discorre sobre a querela entre theoria e praxis, e vida activa e vida contemplativa na polis grega. Depois, em um salto temporal, ele passa para a perspectiva humanista de Montaigne, em que a experiência poderia ser vista, grosso modo, como uma aventura de autodescoberta, para posteriormente, em preparação ao estudo epistemológico, discorrer sobre Francis Bacon e a experiência como experimento científico. Quanto à religião, ele discorre sobre a separação corpo e espírito, e sobre a supremacia deste último, a partir de Immanuel Kant, Friedrich Schleiermacher, William James, Rudolf Otto e Martin Buber. Não entraremos nos pormenores dessas discussões aqui, visto que não se apresentam estritamente relevantes para o estudo, embora extremamente interessantes.
} 
objetos inerentemente belos e a autonomia do Campo da Arte, isto é, a separação da Arte de suas funções religiosa, política, moral e econômica, na Europa do século XVIII. Segundo o autor, essas mudanças foram a base para um novo foco na resposta corporal e sensual do espectador da Arte, bem como para a sua capacidade de exercer o julgamento do gosto. Assim, qualidades antes consideradas como inseparáveis dos objetos passaram a ser discutidas a partir do espectro da percepção do sujeito. Entretanto, o sujeito que emergiu deste discurso não seguia seus desejos e interesses carnais, sendo, em vez disso, considerado inerentemente apenas contemplativo e desinteressado. Esta concepção é fruto da tradição da Crítica do Julgamento de Immanuel Kant (1724-1804), que, grosso modo, qualificava a relação do sujeito com o objeto estético e sua experiência não como satisfação de um interesse ulterior, mas como algo gratuito e livre de desejos e necessidades.

Crítico do pensamento de Kant, já que postulava o que considerava uma concepção mais ativa e abrangente da experiência estética, John Dewey (18591952) é conhecido como expoente do Pragmatismo, um movimento intelectual presente na Europa, mas relevante sobretudo nos Estados Unidos. O Pragmatismo teve início ao final do século XIX com um pequeno grupo de pensadores que se tornaram conhecidos como pragmáticos, após William James popularizar o termo, primeiramente cunhado por Charles Sanders Pierce (1839-1914) — famoso no Campo do Design por seus estudos semióticos — na década de 1870. Jay (2006, p. 265-266) afirma que mesmo antes da fundação da República, os americanos frequentemente se baseavam na retórica da experiência como fonte de legitimação contra a abstração racional ou o peso morto da autoridade não examinada, sobretudo em relação às exigências da coroa inglesa no Novo Mundo. Neste ínterim do pensamento pragmático, a experiência significava tanto uma nova experimentação quanto o aprendizado de lições valiosas do passado para serem aplicadas imaginativamente no futuro. Significava também lucrar a partir de encontros corporais com um ambiente novo, aproveitando as lições que estes produziam na vida cotidiana ordinária dos homens e mulheres comuns, resultando em improvisações acerca de novas maneiras de viver junto, adorar a Deus e dominar a natureza. Assim, esta nova configuração resultou em uma tradição generalizada de identificação da América com o que o filósofo John J. McDermott chamou de 
"cultura de experiência". ${ }^{87}$ Segundo outro observador, John J. Stuhr ${ }^{88}$, "o que é americano na Filosofia é o uso do método de experiência, e não a catalogação sem fim independentemente do contexto de seu uso, muito menos a tediosa formalização de seus resultados em categorias sagradas".

Dewey é conhecido também por seus escritos em educação, nos quais postulava um caráter educativo mais "livre" 89 , sendo citado como principal referência pelos designers que trabalham com Design de Experiência. Jay (2006, p.162-163) afirma que no livro Art as Experience, o autor desejava curar as feridas da vida moderna, ou superá-las em um processo aberto de realização cumulativa, um processo que ele denomina "ter uma experiência", o qual corresponde à conquista de uma unidade holística e orgânica que traz consigo sua própria qualidade individual e autossuficiente, não obstante mantendo a reflexividade momentânea e sua integração cumulativa ao longo do tempo. De acordo com Jay (2006, p. 162), Dewey queria que as distinções entre Arte, Ciência e Filosofia fossem resolvidas e substituídas por uma noção vaga e incontestável de inteligência, tentando resolver problemas e proporcionando significado.

Com efeito, é considerado que Dewey tenha ficado profundamente preocupado com o impulso contemplativo e meramente espectador da noção kantiana de desinteresse estético, o qual, segundo o pragmático, desabonava a tentativa ativa e comprometida de viver a vida no modelo de uma obra de arte. Segundo Jay (2006, p. 163), Dewey também queria superar o fosso entre produtor e consumidor na vida moderna, do qual a cisão entre a criação artística e a apreciação estética foi um sintoma, procurando reconciliá-los com o que ele considerava valores democráticos. Jay (2006, p. 163) afirma que, como Ruskin e Morris, expoentes recorrentes na História do Design, Dewey esperava transcender a distinção entre o útil e o ornamental para transfigurar a vida cotidiana.

\footnotetext{
${ }^{87}$ MCDERMOTT, John J. The Culture of Experience: Philosophical Essays in the American Grain. New York, 1976.

${ }^{88}$ STUHR, John J. Genealogical Pragmatism: Philosophy, Experience and Community. Albany, N.Y., 1997.

${ }^{89}$ Conforme Jay (2006, p. 296), Dewey argumentava que a educação para a democracia era uma necessidade absoluta, e essa educação deveria basear-se em experiências experienciais, em vez de aprendizagem de livros; investigação criativa, em vez de memória rotativa; e uma relação transacional entre criança e ambiente, em vez de uma relação passiva, espectadora. Ele afirmava que seu próprio pensamento vinha mais de contatos e situações pessoais do que de livros.
} 
Ainda, Dewey esperava inspirar o mundo da vida com o que ele considerava o poder redentor da Arte. Em todas as experiências cognitivas, ele insistia, há um momento estético em caráter unificador e de conclusão, afirma Jay. (2006, p. 163164) Ele considerava também que qualquer atividade prática, desde que estivesse integrada e se movesse por sua própria vontade de realização, possuiria qualidade estética. Ao contrário de alguns defensores mais imperialistas da soberania da arte, Jay (2006, p. 165) afirma que Dewey, com respeito pela ciência, buscava um equilíbrio entre os vários tipos de experiência, e não uma aquisição hostil dos outros por um, não obstante considerasse a experiência estética como a experiência autêntica tout court em sua organicidade. Logo, Dewey abraçava a ideia de que praticamente qualquer objeto poderia ser estetizado: "A experiência estética", cita Jay (2006, p. 165), “é sempre mais do que estética. Nela, um corpo de questões e significados não estéticos tornam-se estéticos à medida que entram em um movimento rítmico ordenado para a consumação." Entretanto, tal argumento suscitou críticas, como a de Hans Robert Jauss ${ }^{90}$ (1921-1997), o qual acusou Dewey de adentrar a lógica de um argumento circular, projetando no mundo o que ele clama ter encontrado como a fonte para a experiência estética do cotidiano. Neste ponto, é considerado que Jauss (1982) tenta resgatar a subjetividade que o Pragmatismo, de certa forma, tentava ultrapassar. De qualquer modo, Dewey sustentou que sua noção de experiência estética, a qual ele considerava radicalmente democratizada - a experiência estética como modelo da boa vida , enfrentou os limites do mundo moderno, no qual, conforme cita Jay (2006, p. 166):

O zelo por fazer, o desejo de ação, deixou muitas pessoas, especialmente neste ambiente humano apressado e impaciente em que vivemos, com uma escassez de experiências quase inacreditável, sendo tudo superficial. Nenhuma experiência parece ter a chance de se completar, porque outra coisa é inserida com rapidez. Assim, o que é chamado de experiência é tão disperso e mesclado que quase não merece o nome.

Assim, conforme Jay (2006, p. 167), Art as Experience tornou-se um argumento de implicações políticas explícitas, sendo até mesmo uma das

90 JAUSS, Hans Robert. Aesthetic Experience and Literary Hermeneutics. Minneapolis: University of Minnesota Press, 1982. 
declarações mais poderosas dessa política, pois, segundo Robert Westbrook ${ }^{91}$ indicou claramente, não era um radicalismo dirigido unicamente ao bem-estar material do povo americano, mas também ao fornecimento de experiências consumadas que só poderiam ser encontradas na circulação de mercadorias.

No entanto, Jay (2006, p. 167) arrazoa que essa concepção de experiência correspondeu a um deslocamento da política "real", configurando uma maneira de redenção sem meios para realizá-la através do que normalmente passa pela prática política. Na verdade, o autor continua, a partir de suas origens no século XVIII, o discurso da experiência estética foi perseguido pela dúvida de que poderia ser mais um simulacro compensatório de ativismo político do que uma ação política em si, pois mover-se muito rápido do prazer corporal sublimado fornecido pela Arte para a ação de um corpo político metafórico pode levar à estetização da política, contra as quais Benjamin, que veremos em seguida, advertiu. Assim, haveria uma maneira mais direta e menos deslocada em que a experiência e a política poderiam ser entrelaçadas? Em caso afirmativo, os resultados favoreceriam uma inclinação ideológica, ou a experiência estaria disponível para a mobilização por todo o espectro?

Ampliando a discussão para além da estética de Dewey, Jay (2006, p. 147148) afirma que a soberania da Arte — em oposição à sua mera autonomia significou a esperança de que a Arte pudesse superar os próprios limites da razão. Entendida como um modelo para o desenvolvimento humano na sua mais alta capacidade, como pensou Dewey, a experiência estética poderia ser aclamada como o totalizador das várias capacidades do homem. Entretanto, devemos considerar que nem todos tinham acesso a mesma experiência, sobretudo quando distinguimos o gênio criador de seu simples espectador mortal, pois havia — ou será que podemos afirmar que ainda há, hoje? - a concordância geral de que o gênio possuía, ou possui, uma capacidade aumentada de experiência autêntica, que o colocava, ou coloca, acima do rebanho comum de homens. Segundo Jay (2006, p. 149-151), citando Peter Bürger, ${ }^{92}$ o conceito de gênio servia para especificar uma

\footnotetext{
${ }^{91}$ WESTBROOK, Robert. John Dewey and American Democracy. Cornell University Press, 1991.

${ }^{92}$ BÜRGER, Peter. Some Reflections upon the Historico-Sociological Explanation of the Aesthetics of Genius in the Eighteenth Century. In.: The Decline of Modernism, trans. Nicholas Walker. University Park, 1992.
} 
maneira abrangente e intensiva de experimentar uma realidade radicalmente distinta do tipo limitado de experiência característico da maioria dos seres humanos. Assim, o conceito também indicava a existência de uma experiência limitada para a vida cotidiana da maioria e tentava responder a esse fenômeno. Logo, a experiência estética, em sua versão de reivindicação de soberania, seria um meio de encantar ao invés de transformar radicalmente o mundo existente.

Por fim, deve-se considerar ainda que, conforme Jay (2006, p. 158-160), mesmo quando a experiência perceptual e corpórea do sujeito foi suprimida em nome de uma definição mais conceitual e institucional da prática artística movimento que vai desde Kant, passando por Dewey, até o que brevemente adiantamos aqui da contemporaneidade, mas que será tratado nas duas partes subsequentes deste subcapítulo — o objeto (de arte) continuou sendo menos importante do que o papel do sujeito na definição de alguma forma estética. Com as obras de arte autoconscientemente conceituais e minimalistas na década de 1960, críticos de arte como Michael Fried ${ }^{93}$ lamentaram a dissolução "teatral" de obras atemporais em pequenas ocasiões para a recepção temporal do espectador, baseando-se no pressuposto de que "só a experiência é o que importa" — e como vimos no início deste capítulo, também Pine e Gilmore usam a noção de teatro ou teatralidade - para sustentar a concepção de experiência como mercadoria. $\mathrm{Na}$ década de 1980, críticos literários como Murray Krieger ${ }^{94}$ também lamentaram o nivelamento da Arte, produzindo "a obliteração do reino da Arte, seus objetos, seus museus [...] tudo imergido dentro da inundável experiência”. Ainda, críticos culturais do embelezamento estético da vida moderna, como Wolfgang Welsch ${ }^{95}$, argumentariam na década de 1990 que "as experiências, no entanto, não são, de fato, experiências. Em vez disso, estão mortas e aborrecidas. É por isso que as pessoas rapidamente buscam a próxima experiência e, portanto, correm de uma decepção para a próxima."

Conforme Jay (2006, p. 168-169), até a presente data não foi alcançado nenhum consenso sobre o que a experiência estética é ou deve ser, o que e quão permeáveis são seus limites com outros modos de experiência e se esta deve se

\footnotetext{
${ }^{93}$ FRIED, Michael. Art and Objecthood: Essays and Reviews. Chicago, 1998.

${ }^{94}$ KRIEGER, Murray. Arts on the Level: the Fall of the Elite Object. Knoxville, Tennessee, 1981.

${ }^{95}$ WELSCH, Wolfgang. Undoing Aesthetics. London: Sage, 1997.
} 
contentar com seu status autônomo ou se esforçar para afirmar sua soberania sobre outros tipos de experiência. Esta indefinição abriu espaço para que muitos autores continuassem discutindo os limites da experiência estética, até mesmo lamentando a sua queda de estatuto epistemológico para perversa tática de mercado. Um importante movimento do século $\mathrm{XX}$ que se debruçou sobre esta questão foi a Escola de Frankfurt, a qual veremos a seguir.

\subsection{3.}

\section{A crise da experiência na Escola de Frankfurt}

A partir de 1998, com o já abordado texto Welcome to the Experience Economy de Pine e Gilmore, a noção de experiência toma relevância no Campo do Design e começa a ser, ainda que veladamente, ${ }^{96}$ tratada como mercadoria. Entretanto, a discussão acerca da experiência como mercadoria já rondava os campos da Arte e da Filosofia desde meados das primeiras décadas do século XX. Walter Benjamin (1892-1940), por exemplo, questionou a reprodutibilidade técnica da Arte como algo que ocasionara a perda da sua aura e, consequentemente, seu modo de experiência em seu célebre texto A obra de Arte na era da reprodutibilidade técnica (1934). ${ }^{97}$ John Berger (1926-2017), seguindo os passos de Benjamin, produziu, em 1972, uma série para a BBC, intitulada "Modos de Ver" (Ways of Seeing), a qual viraria livro ${ }^{98}$ no mesmo ano. Nesta série, Berger abordou as mudanças no Campo da Arte a partir de sua capacidade de reprodução pela indústria, o que, consequentemente, resultou também em transformações em seu modo de experiência. Com o desenvolvimento e o progresso industrial capitalista, podemos considerar que esse quadro se "agravou", e a noção da experiência como mercadoria tomou amplitude, aceitação e reprodução, sobretudo pelos principais responsáveis

\footnotetext{
${ }^{96}$ Empregamos aqui o termo veladamente, pois o Campo do Design não trata a experiência explicitamente como mercadoria. Afirmamos que sua forma de ocorrência é como a de uma mercadoria, mas os agentes do Campo a definem imprecisamente como outra coisa, que também não é clara, conforme já vimos na primeira parte deste capítulo.

${ }^{97}$ BENJAMIN, Walter. A obra de arte na era da reprodutibilidade técnica. In.: Adorno et alii. Teoria da Cultura de Massa. São Paulo: Paz e Terra, 2000. Por mais que possamos considerar a noção de experiência de Benjamin como idealista ou romântica - há muita discussão acerca desta perspectiva -, tal fato não invalida a relevância do seu argumento para a investigação que aqui toma forma.
}

${ }^{98}$ BERGER, John. Ways of Seeing. Penguin, 1972. 
por sua propagação, o mercado e a mídia. Entretanto, ao mesmo tempo em que se discutia, no Campo do Design, a experiência como mercadoria com a característica fundamental de centrada no usuário, no Campo da Filosofia, a discussão beirava até mesmo uma experiência sem sujeito, conforme veremos no próximo subcapítulo. Agora, faz-se mister investigar as bases para essa possibilidade de experiência sem sujeito, e essa fundamentação advém dos escritos da Escola de Frankfurt e autores contemporaneamente associados a ela. ${ }^{99}$

Também lutando por uma noção de experiência mais holística, porém distinta daquela de Dewey, Walter Benjamin, segundo Jay (2006, p. 159) defendeu uma experiência tanto antropológica quanto estética, a qual buscava recuperar o mundo perdido de correspondências e semelhanças que havia secado com o início do desencanto moderno. Evitando o narcisismo daqueles que queriam transformar suas vidas em obras de arte e hostis à colonização estética do resto do mundo, Jay (2006, p. 159) afirma que Benjamin procurou restaurar uma noção de experiência que diminuiu a importância do sujeito de julgamento e restaurou a importância da obra de Arte.

Escrevendo em maio de 1940 de seu exílio em Paris, Benjamin expressou a Theodor W. Adorno (1903-1969) — expoente da Escola de Frankfurt, o qual veremos a seguir —, este recentemente erradicado em Nova York, sua angústia em relação à "metódica desconstrução da experiência." (JAY, 2006, p. 312) Benjamin já escrevia sobre o tema desde 1913, afirmando que o estado espantoso em que se encontrava a experiência genuína era um dos indicadores mais reveladores do declínio da era moderna ao barbarismo. A Teoria Crítica da Escola de Frankfurt encontrou na crise da experiência um desastre humano comparável à "reificação"100 que Georg Lukács (1885-1971) argumentou em 1923, em História e Consciência de Classe $^{101}$, como a essência da exploração do capitalismo.

Compartilhando com os pragmatistas americanos - cujo trabalho ele nunca pareceu conhecer diretamente - a busca pela totalidade da experiência negada pelo

\footnotetext{
${ }^{99}$ Há discussões sobre o pertencimento ou não de Walter Benjamin à Escola de Frankfurt. Seus escritos são associados à Escola, mas ele não fez parte dos membros originais.

${ }^{100}$ Grosso modo, entendida como relações entre pessoas que tomam o caráter de relações entre coisas. Entraremos nessa discussão com mais profundidade no Capítulo 3 - Da mercadoria.

${ }^{101}$ LUKÁCS, Georg. História e consciência de classe: Estudos sobre a dialética marxista. São Paulo: Martins Fontes, 2003.
} 
mundo moderno, Jay (2006, p. 313) afirma que Benjamin tinha o desejo de superar a modalização da experiência em suas partes componentes e curar a separação entre sujeito e objeto. Assim, a noção de experiência de Benjamin traz uma insistência na importância de detalhes aparentemente triviais, na valorização de momentos infantis de prazer, no fascínio com a ressonância aurática dos nomes dos lugares e na apreciação da mentalidade do colecionador, bem como no emaranhamento da memória e da experiência — especialmente das memórias de infância que se impõem "inesquecíveis" na mente de Benjamin.

Jay (2006, p. 328) esclarece que Benjamin permaneceu sempre a uma distância considerável de qualquer movimento político concreto: ao invés de exaltar as virtudes da experiência revolucionária, seu trabalho voltou-se cada vez mais a registrar a impossibilidade - ou pelo menos, dificuldade extrema — de alcançar uma experiência autêntica no mundo moderno. Usando palavras como atrofia (Verkümmerung) e pobreza (Armut) para descrever o que estava em perigo de desaparecimento, ele lamentou a degradação da experiência que viu em seu entorno. Esta degradação pode ser notada também em romancistas como o austríaco Robert Musil, cuja grande obra-prima inacabada, The Man Without Qualities ${ }^{102}$, ambientada em 1913 em Viena, inclui a seguinte lamentação, que vale nota para o pensamento também no Campo do Design contemporâneo. Em citação de Jay (2006, p. 328-329):

\begin{abstract}
Não percebemos que as experiências se tornaram independentes das pessoas? [...] Surgiu um mundo de qualidades sem um homem, de experiências sem a pessoa que as experimenta, e parece que a experiência privada ideal é uma coisa do passado, e que o fardo amigável da responsabilidade pessoal vai dissolver-se em um sistema de fórmulas para possíveis meios.
\end{abstract}

Jay (2006, p. 329-330) considera que uma ênfase mais histórica e política se tornou evidente em Experiência e Pobreza ${ }^{103}$, livro de 1933, que Benjamin publicou no primeiro ano de seu exílio. A pobreza da experiência significava para Benjamin uma nova variedade de barbarismo, que além de envolver o indivíduo,

\footnotetext{
${ }^{102}$ MUSIL, Robert. The Man without Qualities. (Originalmente publicado em 1930). Vol. 1, trans. Sophie Wilkins, New York, 1996.

${ }^{103}$ BENJAMIN, Walter. Experience and Poverty (1933). In.: Selected Writings, vol. 2, 2005.
} 
ocasionava também o esgotamento da própria cultura. Entretanto, mesmo no colapso, Benjamin enxergava uma nova oportunidade: a ideia de pobreza de experiência não deveria significar que as pessoas queriam novas experiências, mas sim que elas queriam se livrar de experiências, que elas queriam viver em um mundo em que pudessem fazer um uso puro e decidido de sua pobreza - o que levaria a algo respeitável. Contudo, conforme Jay (2006, p. 330-331), esse algo novo, essa nova oportunidade, poderia significar uma mera cultura de sobrevivência, como acabou sendo entendido por seus leitores e estudiosos.

Ainda, o que Benjamin considerava a atrofia da experiência autêntica foi expressada na perda - ou mais precisamente, no declínio ou decadência — da "aura", que ele definiu em referência a objetos naturais como "um tecido estranho do espaço e do tempo: a aparência única ou a aparência da distância, não importa que seja próxima"104 Jay (2006, p. 333) declara que essa distância era tão temporal quanto espacial, porque envolvia a experiência de uma distinção entre passado e presente, a qual corria o risco de entrar em colapso no mundo moderno. Sem essa distância, a capacidade do objeto de retornar o olhar, a qual Benjamin considerou fundamental para impedir a dominação do sujeito sobre o objeto, seria comprometida.

Jay (2006, p. 333-334) explica que, a seu modo, Benjamin comemorou a decadência da aura como produtora de efeitos políticos positivos ao nos libertar da dependência cultural. Em $A$ obra de arte na era da reprodutibilidade técnica $(1934)^{105}$, o autor considerou que a arte tecnicamente reproduzida acarretou em um "valor de exposição" que ampliou sua capacidade de apropriação pelas massas. Em outros momentos, entretanto, ele reconheceu o permanente potencial crítico e preocupou-se com uma possível completa extirpação. Em 1939, Benjamin argumentou que a substituição da narração mais antiga pela informação e da informação pela sensação refletia a crescente atrofia da experiência, em uma crítica ao que considerava a substituição da narrativa pela informação, de acordo com suas primeiras definições de experiência. ${ }^{106}$

\footnotetext{
${ }^{104}$ BENJAMIN, Walter. Little History of Photography (1931). In.: Selected Writings, vol. 2, 2005.

${ }^{105}$ Ver referência na nota 95.

${ }^{106}$ BENJAMIN, Walter. On some motifs in Baudelaire (1939). In.: Illuminations, 1969.
} 
É com Benjamin que temos ainda um claro uso dos termos Erlebnis e Erfahrung, explicados anteriormente no contexto etimológico. Conforme define o autor, "há uma espécie de experiência [Erlebnis] que anseia o único, o sensacional; e outro tipo [Erfahrung] que procura a igualdade eterna."107 Jay (2006, p. 334) aponta que enquanto a primeira correspondia a ocorrências singulares, incapazes de criar repetições significativas ao longo do tempo, a última tinha durabilidade. No texto em que faz esta distinção, Benjamin trata do livro Walking in Berlin, de Franz Hessel, que mais tarde influenciará o pensamento de Baudelaire sobre oflâneur em Paris - considerando a experiência deste como Erfahrung. Sobre Baudelaire, Jay (2006, p. 337) pontua que Benjamin considerou-o o primeiro a reconhecer e tentar afastar as mudanças produzidas pela vida na cidade moderna e pela redução do trabalho do artesão para a produção da linha de montagem, já que essas mudanças, a reboque do princípio da troca capitalista, dissolviam relacionamentos tradicionais e reduziam tudo a "commodities fantasmagóricas". Assim, Benjamin considerava que, para toda a sua atrofia e decadência, alguma Erfahrung ainda era possível no mundo moderno e, de fato, poderia ser a base para um método crítico. E essa experiência poderia justificadamente ser chamada de histórica. Contudo, segundo Jay (2006, p. 337), esta não poderia consistir de simples recuperações miméticas, como as primeiras definições de Benjamin para experiência, mas sim de um processo mais complicado que combinasse momentos passivos e ativos, em que ambos reconheceriam os choques traumáticos da vida moderna e encontrariam uma maneira de salvá-los para uma futura realização da experiência em seu modo mais redentor.

No desdobramento das considerações sobre experiência no pensamento da Escola de Frankfurt, Jay (2006, p. 343-360) trata de Adorno. Não obstante muito próximo e utilizando alguns pontos do pensamento de Benjamin para seu entendimento de experiência, as conceituações de Adorno ${ }^{108}$ apresentaram algumas sutis diferenças. Conforme Jay (2006, p. 343-344), Adorno, por exemplo, nunca mostrou ambivalência acerca da decadência da experiência: para ele, não houve nenhum pensamento ilusório sobre as oportunidades abertas para uma renovação radical, nem celebração do poder libertador das novas tecnologias em si mesmas.

\footnotetext{
${ }^{107}$ BENJAMIN, Walter. The Return of the Flaneur (1929). In.: Selected Writings, vol. 2, 2005.

${ }^{108}$ ADORNO, Theodor. W. Negative Dialectics. New York, 1973.
} 
Tendo sobrevivendo à Segunda Guerra Mundial e ao Holocausto, o autor reforçou seu cuidado prévio quando se tratava de soluções políticas radicais de qualquer tipo e assim, para ele, a crise de experiência foi apenas uma fonte de lamentação.

De acordo com Jay (2006, p. 348-349), a conceituação de experiência de Adorno se aproximava mais da definição de experiência de Hegel, conforme esta é descrita por Heidegger. ${ }^{109}$ Não entraremos nessa querela, tendo em vista nossa limitação de conhecimento do corpus teórico, tempo e espaço, mas devemos assinalar sinteticamente que, para Hegel, a experiência é formada pela subjetividade do sujeito, ou seja, é a experiência que sustenta o ser. Considerando seu método dialético como fundamentado em uma visão subjetiva da experiência, diferente da virada materialista dialética que Marx traz no século XIX, podemos considerar, então, que a subjetividade da experiência de Hegel destoa do entendimento de Benjamin de uma experiência sem sujeito. É a partir dessa proximidade com Hegel que Adorno ${ }^{110}$ positivamente mencionou o trabalho de Dewey, em um ponto curioso para Jay (2006, p. 353-354), posto que a Escola de Frankfurt depreciava os postulados pragmáticos. Adorno não compartilha do entusiasmo de Dewey pelas novas tecnologias e pela noção de experiência como experimento, mas sustenta seu ponto de vista positivo acerca de Dewey ao considerar a substância da experiência como algo potencialmente aberto ao novo, ao invés de uma ratificação do que já ocorreu.

Segundo Jay (2006, p. 354-355), em uma mudança da noção de experiência mais abrangente para a noção de experiência estética, Adorno ${ }^{111}$ postulou que esta não poderia ser pura se devesse ser experienciada. Assim, a experiência estética configurou-se necessariamente impura, porque prejudicada pelas mudanças além Campo da Arte, como a guerra moderna, a substituição da narrativa pela informação, a tecnologia alienante e a industrialização capitalista. Logo, seu verdadeiro conteúdo deveria ser investigado por uma análise teórica filosófica e social que fornecesse as ferramentas críticas discursivas que à Arte inevitavelmente faltavam. Segundo Jay (2006, p. 355-356), Adorno ainda afirmou que a experiência, apesar de ser muitas vezes compreendida em termos subjetivos, consistia apenas de

\footnotetext{
${ }^{109}$ HEIDEGGER, Martin. Hegel's concept of experience. New York, 1970.

${ }^{110}$ ADORNO, Theodor W. Aesthetic Theory. Minneapolis, 1997.

${ }^{111}$ ADORNO, Theodor W. Notes on Literature. Vol. 2. Columbia University Press, 1992.
} 
um encontro com a alteridade em que o eu não permaneceria mais o mesmo. Logo, para não ser destruída, essa experiência deveria tratar o outro de uma maneira não dominante, não substitutiva e não homogeneizadora, como se fosse um nome próprio que se referisse apenas a si mesmo e que não servisse como símbolo de outra coisa. Este teria sido o papel da mímesis, herdada de Benjamin, entendida como mais do que a reprodução fiel do mundo tal como é.

Por esta razão, Jay (2006, p. 356) afirma que a preservação do objeto de arte concreto, particular e autônomo torna-se uma dimensão absolutamente crucial da experiência estética de Adorno, o que significa que o lamento pelo desaparecimento do objeto e a hipertrofia do sujeito são baseados em uma compreensão unilateral da experiência como apenas Erlebnis, refletindo a redução da experiência no mundo moderno. Assim, a Arte não deveria ser entendida como uma expressão da Erlebnis pessoal do artista, que é capaz de provocar uma experiência vivida comparável no leitor, espectador ou ouvinte: em vez disso, a Arte deveria ser entendida como transcendente do estado emocional do artista e deveria ser capaz de despertar um sentimento de preocupação (Betroffenheit) no espectador, que decorreria do tremor (Erschütterung) que ele ou ela sente diante do trabalho em si, um tremor tão intenso que registraria a dolorosa liquidação do ego na modernidade. Segundo Jay (2006, p. 357), aqui o sujeito expropriado da experiência emergiria para validar o que, do ponto de vista da ciência, poderia aparecer apenas como a sua negação mais radical: uma experiência sem sujeito nem objeto, absoluta.

Para Adorno, a experiência intacta, a experiência autêntica — se de fato tal condição pode ser alcançada — não significaria uma restauração da inocência antes da linguagem ou uma reconciliação harmoniosa em um futuro utópico, mas sim um relacionamento não dominante entre assunto e objeto. Com efeito, Jay (2006, p. 359-360) aponta que a felicidade experiencial que é prometida pelas obras de arte restaura um dos sentidos fundamentais da própria experiência: um sofrimento passivo ou em ocorrência, em um encontro com o novo e o outro, que nos move para além do que nós, como sujeitos, éramos antes da experiência começar.

O próprio Adorno, admite Jay (2006, p. 336) em conclusão, nunca resolveu completamente a confusão de denotações e conotações que se apegaram à palavra experiência. Por vezes, ele expressou nostalgia por uma experiência perdida e intacta; em outros momentos, ele zombou da sua possibilidade. Ao invocar a retórica de uma perda progressiva, ele apenas sugeriu vagamente a existência de 
um tempo histórico real antes da decadência. Quem trata da dimensão histórica da experiência é Raymond Williams e Joan Scott, conforme veremos a seguir.

\subsection{4.}

\section{A estrutura e a ausência do sujeito}

Raymond Williams (1921-1988) trata da noção de experiência por uma perspectiva histórica e, sobretudo, política. Faz-se mister discorrermos sobre suas considerações agora, pois ele foi um importante expoente no pensamento materialista crítico, apontando e discutindo a relação entre a estrutura e o sujeito. Enquanto os escritos da Escola de Frankfurt tomavam conta também da estrutura, mas principalmente pelo viés da perda, da nostalgia que a sobreposição desta incutia ao sujeito - não obstante Benjamin vislumbrasse uma possibilidade de ruptura , em Williams podemos identificar com maior especificidade a relação entre sujeito e estrutura por um viés concreto das condições econômicas, sociais e políticas.

Segundo Jay (2006, p. 191-192), Williams sintetizou sua definição de experiência como uma "formação histórica da subjetividade, variável entre e dentro das sociedades, mas nunca uma constante perceptual", ou seja, uma noção situada historicamente. Em um balanço mais detalhado, o autor debruçou-se sobre o termo com maior atenção em três momentos da sua obra, no livro Culture and Society $(1958)^{112}$, The Long Revolution (1961) ${ }^{113}$ e mais especificadamente, Keywords (1976). ${ }^{114}$ Em Culture and Society (1958), ele fez um apelo ao rejuvenescimento de uma cultura comum que suturaria as feridas da modernização industrial e restauraria a possibilidade de uma comunicação genuína baseada em "uma comunidade efetiva de experiência". Jay (2006, p. 192-193) aponta que não obstante Williams não tenha prestado atenção à cultura da classe trabalhadora ${ }^{115}$,

\footnotetext{
${ }^{112}$ WILLIAMS, Raymond. Culture and Society. New York, 1958.

113 WILLIAMS, Raymond. The Long Revolution. London, 1961.

114 WILLIAMS, Raymond. Keywords: a vocabulary of culture and society. London, 1976.

115 Quem toma conta desta perspectiva é E. P. Thompson, em A Formação da Classe Operária Inglesa, um importante livro para a história social e laboral. Experiência foi um conceito-chave neste livro. Segundo Thompson (apud. JAY, 2006, p. 193), "Nós exploramos tanto na teoria quanto na prática os conceitos de junção (como 'necessidade', 'classe' e 'determinação'), através dos quais,
} 
seus instintos eram democráticos, inclusivos e cautelosamente otimistas. Em The Long Revolution (1961), ele postulou que a experiência das "massas" seria reconhecida como a base de uma nova cultura igualitária, e que o registro dessa experiência se faria evidente em uma "estrutura de sentimento"116 definida como o resultado vivo e particular de todos os elementos da organização geral dessa cultura, a qual poderia ser acessada retrospectivamente através de suas artes, visando fins emancipatórios contemporâneos. Entretanto, Jay (2006, p. 195-196) afirma que dever-se-ia atentar para o fato de que, reprimidas e abafadas, por mais resistentes que fossem as articulações diretas, tais experiências poderiam também ser o material de uma potencial contra-história para a narrativa dominante. Entraremos mais a fundo neste tópico com Joan Scott, mas já podemos adiantar que também ela compartilha de uma ênfase na natureza coletiva e intersubjetiva, mais do que um fenômeno interno da psique isolada, em oposição à natureza individual e destacada.

Ainda sobre Williams, Jay (2006, p. 200-201) afirma que ele entendia então a experiência não como um valor inalterável ou metafísico - um único critério paradigmático de julgamento subjetivo - mas como valor sujeito à história. Neste sentido, o desenvolvimento de Williams do conceito de "estrutura do sentimento" é projetado exatamente para restaurar a categoria de experiência para o mundo, como um parto de sua história social mutável e variável, com a capacidade de mudança - sentido que não encontramos no Campo do Design, ao menos não com sentido crítico.

Em Keywords (1976), o autor esboça os sentidos através dos quais o termo experiência tem sido empregado na tradição anglo-americana. Ele os resume como i) conhecimento recolhido de eventos passados, seja por observação consciente ou por consideração e reflexão - uma experiência passada; e ii) um tipo particular de consciência que pode, em alguns contextos, ser distinto da "razão" ou “conhecimento" - uma experiência presente. Conforme Jay (2006, p. 201-202), Williams afirma que até o início do século XVIII, a experiência e o experimento

por meio da falta do termo 'experiência', a estrutura é transformada em processo, e o sujeito reentra na história."

${ }^{116}$ Quem também faz uso do termo "estrutura de sentimento" — talvez ecoando Williams —é David Harvey, em seu livro Condição Pós-Moderna: uma pesquisa sobre as origens da mudança cultural (1989). Abordaremos este escrito no Capítulo 3 - Da mercadoria. 
foram termos intimamente relacionados, designando o conhecimento alcançado através de testes e observações. Ainda no século XVIII, o autor postula que a experiência continha não apenas a noção de consideração ou reflexão sobre os eventos observados, das lições adquiridas no passado, mas também se referia a um tipo particular de consciência. Esta consciência, no século XX, passou a significar uma "consciência plena e ativa", incluindo sentimento e pensamento. Logo, a noção de experiência como testemunho subjetivo passou a ser oferecida não só como verdade, mas como o tipo de verdade mais autêntico, como o terreno para todos (subsequentes) raciocínios e análises. Entretanto, segundo Jay (2006, p. 203-204), para Williams, essa noção de experiência adquiriu outra conotação no século XX, diferente das noções de testemunho subjetivo como imediato, verdadeiro e autêntico, pois passou a considerar as influências externas - condições sociais, instituições, formas de crença ou percepção - , coisas "reais" fora da experiência às quais elas reagem e não incluem seu pensamento ou consideração. Assim, Jay (2006, p. 204-205) arrazoa que Williams vinculou a noção de experiência com o conceito holístico de cultura, o que significou que a experiência era mais do que meramente subjetiva e individual, mas que também não se restringia meramente ao efeito de condições ou crenças sociais.

Com efeito, esperançoso de evitar esses dois extremos, Jay (2006, p. 205) postula que Williams concluiu sua conta ao notar que a "experiência passada" inclui tratados de consideração, reflexão e análise que o uso mais extremo da experiência presente - uma autenticidade e imediatismo inquestionáveis — exclui. Do mesmo modo, a redução da experiência para o material sempre produzido a partir de outro lugar também depende da exclusão de tipos de consideração, reflexão e análise, pois não é então que tais tipos não sejam testados, mas sim que todos os tipos de evidências e suas considerações devem ser tentadas.

Jay (2006, p. 211) considera que ao desdobramento histórico seguinte a Williams, o debate sobre a experiência mudou-se para um novo terreno, o do movimento dos estudos culturais nascente nos ambientes acadêmicos, o qual acompanhou o surgimento das chamadas políticas de identidade que têm como um de seus principais expoentes a historiadora Joan Scott.

Assim, se com a crise da experiência vimos uma mudança tanto no sujeito quanto no objeto a ser experienciado - o sujeito sendo substituído pela estrutura, e o objeto esvaziado de significado ou transformado em mercadoria - chegamos 
então às condições que propiciaram o surgimento do que foi chamado de ausência do sujeito. Esta noção foi pensada a partir da chamada "virada linguística" (linguistic turn), que dominou primeiramente a Filosofia e depois as Humanidades, no século XX. Definida como uma frase atrativa para críticas divergentes de paradigmas históricos, narrativas e cronologias abrangendo não só a crítica linguística pós-estruturalista, a teoria linguística e a filosofia, mas também a antropologia cultural e simbólica, o novo historicismo e a história de gênero, Jay (2006, p. 247-248) considera que a virada linguística se tornou um locus para os críticos da experiência como objeto da pesquisa histórica. Um exemplo destes críticos é Joan Scott, historiadora que pesquisou a história da classe trabalhadora europeia, em 1980, pela vertente da chamada história da diferença, ou seja, a história da designação do "outro", da atribuição de características que distinguem categorias de pessoas de alguma norma presumida - e geralmente não declarada —, trazendo um pouco do que Edward P. Thompson (1924-1993) definiu como History from Below ${ }^{117}$, que influenciou outras frentes de pensamento como, por exemplo, os Subaltern Studies, com Gayatri Chakravorty Spivak. ${ }^{118}$ Segundo Jay (2006, p. 249), Scott afirma que os historiadores deveriam perguntar como e de que maneiras as concepções de classe organizaram (as percepções de) experiência social. Em seu ensaio amplamente comentado, publicado pela primeira vez em 1991, chamado The Evidence of Experience ${ }^{119}$ - o que agora abordaremos -, Scott mobiliza a retórica desconstrucionista da diferença e expressa uma desconfiança pós-estruturalista de fundamentos transcendentais, desafiando diretamente a celebração da experiência por historiadores que aumentaram o alcance de sua pesquisa para incluir o anteriormente ignorado.

Neste texto, Scott dialoga diretamente com Williams. Considerando a classificação do autor da experiência como estabelecedora da existência anterior do indivíduo, seja ela concebida como interna ou externa, subjetiva ou objetiva, Scott afirma que Williams opera dentro de uma construção ideológica que não apenas torna os indivíduos o ponto de partida do conhecimento, mas também naturaliza

\footnotetext{
117 THOMPSON, Edward. P. History from Below. In.: Times Literary Supplement, 7 April 1966. ${ }^{118}$ SPIVAK, Gayatri C. Can the Subaltern Speak? In.: Marxism and the Interpretation of Culture. London: Macmillan, 1988.

${ }^{119}$ SCOTT, Joan W. The Evidence of Experience. In: Critical Inquiry 17, no 4, Summer, 1991.
} 
categorias como homem, mulher, preto, branco, heterossexual e homossexual, tratando-os como características específicas dos indivíduos. Assim, Scott (1991, p. 782) considera que quando é definida como existência interna, é uma expressão do ser ou consciência de um indivíduo; porém quando é externa, é o material sobre o qual a consciência age e, neste sentido, falar sobre a experiência dessa maneira nos leva a considerar a existência de indivíduos como certo - a experiência é algo que as pessoas têm -, em vez de perguntar como as concepções de si mesmos - dos sujeitos e suas identidades — são produzidas. Como contraponto, ela traz a redefinição da experiência de Teresa de Laurentis $(1984)^{120}$, que expõe o funcionamento desta ideologia. "Experiência", afirma Laurentis, é o processo pelo qual, para todos os seres sociais, a subjetividade é construída. Através desse processo, segundo Scott (1991, p. 782), alguém se coloca ou é colocado na realidade social, e assim se percebe e se compreende como subjetivo (referindo-se, originando-se a si mesmo) nessas relações - materiais, econômicas e interpessoais — de fato sociais e, em uma perspectiva maior, históricas. Logo, Scott (1991, p. 782-783) afirma que os conceitos de experiência descritos por Williams impedem o inquérito sobre os processos de construção do assunto e evitam examinar as relações entre o discurso, a cognição e a realidade, a relevância da posição ou situação dos sujeitos para o conhecimento que produzem e os efeitos da diferença no conhecimento. Ela prossegue discorrendo que as questões não são levantadas sobre, por exemplo, a importância da história que eles escrevem, se os historiadores são homens, mulheres, brancos, negros, heterossexuais ou homossexuais. Em vez disso, "a autoridade do sujeito do conhecimento" é medida pela eliminação de tudo sobre o falante. Com efeito, seu conhecimento, refletindo como algo diferente dele, é legitimado e apresentado como universal, acessível a todos. Ela afirma, portanto, que não há poder ou política nessas noções de conhecimento e experiência.

Deste modo, Scott (1991, p. 785) aponta que o aspecto unificador da experiência exclui campos inteiros da atividade humana, simplesmente por não os contar como experiência, pelo menos não como relevantes para a organização social ou política. A autora afirma que quando a classe se torna uma identidade primordial, outras posições de assunto são subsumidas por ela, como as de gênero ou história,

${ }^{120}$ LAURENTIS, Teresa. Alice doesn't: Feminism, Semiotics, Cinema. Bloomington: Indiana University Press, 1984. 
raça, etnia e sexualidade. As posições de homens e mulheres e suas diferentes relações com a política são tomadas como reflexões de acordos materiais e sociais e não como produtos da própria política de classe - eles fazem parte da "experiência" do capitalismo. Em vez de perguntar como algumas experiências se tornam mais salientes do que outras - como o que importa para Thompson é definido como experiência e como as diferenças são dissolvidas - a experiência se torna cumulativa e homogeneizadora, fornecendo o denominador comum sobre o qual a consciência de classe é construída.

Em vez disso, uma possível mudança de foco seria, ao invés de naturalizar a "experiência" através de uma crença na relação sem mediação entre palavras e coisas, considerar todas as categorias de análise como contextuais, contestadas e contingentes. Assim, deveríamos questionar: como as categorias de representação e análise - como a classe, a raça, o gênero, as relações de produção, a biologia, a identidade, a subjetividade, a agência, a experiência, até mesmo a cultura alcançaram seu status fundamental? Quais foram os efeitos de suas articulações? O que significa para os historiadores estudar o passado em termos dessas categorias e para os indivíduos pensarem neles nesses termos? Qual é a relação entre a relevância de tais categorias em nosso próprio tempo e sua existência no passado?

Scott (1991, p. 796-797) afirma que, não obstante a ubiquidade do termo, fazse útil trabalhar com ele, analisar suas operações e redefinir o seu significado, sobretudo por este ser um termo tão presente no nosso cotidiano. Isso implica focar nos processos de produção identitária, insistindo no caráter discursivo da "experiência" e na política de sua construção. A experiência já é sempre uma interpretação e algo que precisa ser interpretado. Assim, o que conta como experiência não é evidente nem direto; é sempre contestado e sempre, portanto, político. Logo, o estudo da experiência deve contestar seu status originário na explicação histórica.

Para o Campo da História - e usamos este texto por pensar que ele pode nos ajudar também no Campo do Design, então dizemos que isto vale também para os designers - , essa contestação só acontecerá quando os historiadores (ou designers) tomarem como seu projeto não a reprodução e transmissão do conhecimento que se diz ser alcançado através (e para) da (a) experiência, mas a análise da produção desse conhecimento em si. Tal análise constituiria uma história genuinamente não fundacional, que retém o seu poder explicativo e seu interesse em mudanças, mas 
não mantém ou reproduz categorias naturalizadas. Ainda, também não se pode garantir a neutralidade do historiador (designer), pois decidir quais categorias historicizar é um ato inevitavelmente político, necessariamente ligado ao reconhecimento do historiador de sua participação na produção do conhecimento. A experiência torna-se, então, não a origem da nossa explicação, mas aquilo que queremos explicar. Esse tipo de abordagem não prejudica a política negando a existência de assuntos. Em vez disso, interroga os processos de sua criação e, ao fazê-lo, refuta a história e o papel do historiador e abre novas maneiras de pensar sobre mudanças.

Deste modo, Jay (2006, p. 250) aponta que em vez de uma realidade vivida no passado que poderia ser reexaminada no presente pelo historiador empático, “experiência”, para Scott, é sempre uma categoria de construção que contém dentro dela os resíduos ideológicos do contexto discursivo do qual emergiu e, mesmo ao se concentrar em assuntos coletivos, a simples exposição de experiências ao olhar do historiador parece fazer pouco para iluminar as condições estruturais que as permitiram, pois por mais que exponham a existência de mecanismos repressivos, não evidenciam seu funcionamento interno ou lógica, não a entendem como constituída relacionalmente. Para isso, Scott afirma, é preciso atender aos processos históricos que, através do discurso, posicionam os sujeitos e produzem suas experiências. Não são os indivíduos que têm experiência, mas sujeitos que são constituídos através da experiência.

Assim, a experiência tanto como o objeto da pesquisa histórica e algo possuído pelo historiador contemporâneo que procurava reexaminar ou reeditar o passado foi inevitavelmente mediado precisamente pelas relações linguísticas e estruturais que seus celebrantes procuravam colher. Com efeito, conforme Jay (2006, p. 250-252), apenas uma resistência radical a qualquer elemento essencial de categorias como a experiência, que deveria ser entendida como um termo discursivo em vez de determinado, poderia restaurar uma dimensão política à pesquisa histórica. Apenas uma genealogia de conceitos fundamentais como a experiência - e aqui Scott apelou direto para a apropriação de Michel Foucault do método nietzschiano - poderia expor os resíduos ideológicos em seu uso inocente.

No final de seu ensaio, Scott (1991, p. 797) admite, em citação que Jay utiliza na introdução de Songs of Experience, que: 
A experiência não é uma palavra que podemos viver sem, pois apesar de ter sido usada para essencializar a identidade e reificar o assunto, é tentador abandoná-la completamente. Experiência é uma parte da linguagem cotidiana, tão imbricada em nossas narrativas que parece inútil argumentar por sua expulsão.

O resultado benéfico não seria a abolição do assunto, mas sim uma compreensão de como ele se torna relevante em primeiro lugar. Com efeito, enquanto alguns aceitaram a crítica de Scott sobre as noções ingênuas da história como a recuperação da experiência passada, eles se perguntaram sobre sua redução de experiência para nada além de uma função do discurso, não deixando espaço para discursos contra-hegemônicos possíveis, como um crítico por "uma experiência semiautônoma e/ou contraditória com as construções discursivas dominantes". Segundo Jay (2006, p. 252), talvez o veredito geral tenha sido resumido por Kathleen Canning ${ }^{121}$, que observou: "Scott oferece uma desconstrução magistral do conceito de experiência, mas para de fato redefinindo ou reescrevendo-o. Então, mesmo que possamos concordar com ela sobre o que a experiência não é (transparente, visceral), não temos certeza sobre o que poderia ser”. A própria Scott, ao responder a seus críticos, admitiu que o trabalho ainda era necessário para esclarecer um conceito viável de experiência. Conforme Jay (2006, p. 253), ela considerava que em alguns círculos, a experiência ainda era terreno para uma política de identidade que compreendesse as diferenças entre os seus constituintes. Neste ínterim, a experiência é tomada como uma descrição precisa dos sistemas fechados de dominação e opressão, e o conhecimento é considerado o simples reflexo da experiência objetiva. Diante disto, a autora afirma que essa é a versão da experiência que ela pretende questionar, substituindo a noção de experiência como uma leitura teorizada que é possível, mas não inevitável ou singular, pela relação de alguém com instituições e discursos dominantes.

Com efeito, é a partir dessas condições de pensamento da experiência que podemos caminhar para a consideração da experiência como um campo de força dinâmico entre todos esses elementos, nem inteiramente dentro nem fora do eu, um eu que antes de experimentar se recusa a ser reduzido a seus modos transcendentais ou empíricos, e que geralmente segue uma lógica de repetição e deslocamento em

${ }^{121}$ CANNING, Kathleen. Feminist History after the Linguistic Turn: Historicising Discourse and Experience. In.: Signs 19, no. 2, 1994. 
vez de transcendência dialética. Segundo Jay (2006, p. 254), essas condições envolvem linguagem, mas a excedem; estão disponíveis para a observação objetiva, mas constituem também ficção produzida após o fato; buscam ativamente momentos de intensidade extática, mas reconhecem o poder da passividade e abertura para o que pode vir sem querer.

Deste modo, quando pensamos o Design da Experiência como tecnologicamente determinado, como um sistema projetado para ocorrer, será que não estamos liquidando o sujeito, ou melhor, o usuário, resumindo-o a estruturas de ação e reação, estruturas de sentido? E qual a medida de definição da experiência por essas estruturas? Há possibilidade de escape? Podemos adaptar uma afirmação de Wilhelm Dilthey ${ }^{122}$ (1833-1911) ao Campo do Design hoje: há sangue, ou somente linfa - e aqui, talvez uma linfa tecnologicamente diluída - correndo nas entranhas deste ser que experiencia? E essa linfa, a que propósito serve? Partiremos agora para o estudo da noção de mercadoria, aquela que hoje em dia parece dar o significado ao termo tão complexo que recém analisamos.

${ }^{122}$ DILTHEY, Wilhelm. Introduction to the Human Sciences: an attempt to lay a foundation for the study of society and history. Detroit, 1988. 
3.

\section{DA MERCADORIA}

Designers e teóricos se opõem ao entendimento das experiências que projetam ou para as quais projetam - como mercadorias. Já vimos no capítulo anterior as posições de Hassenzahl (2011) e Pine e Gilmore (2013) contra a "comodificação" da experiência, considerando esse processo como algo negativo, o qual retiraria da experiência a sua autenticidade e unicidade. Entretanto, o que exatamente quer dizer "comodificar" algo? Se vamos atrás de uma definição do termo - inexistente nos dicionários de língua portuguesa - encontramos suas raízes no pensamento de Karl Marx (1818-1883). Uma busca rápida no Google nos direciona ao termo commodification - oriundo do termo commodity, que significa mercadoria em inglês - cuja definição mais completa podemos encontrar na Encyclopedia of Marxism. ${ }^{1}$ Esta descreve a comodificação como uma transformação de relações anteriormente não mantidas pelo comércio - em relações comerciais, relações de troca, de compra e venda, ou seja, o processo pelo qual um valor econômico é atribuído a algo que não o possui, indicando uma substituição de valores sociais por valores de mercado. A definição do verbete afirma ainda que esse termo começou a ser utilizado em 1977, depois de uma publicação da Liga dos Jovens Comunistas dos EUA na edição de outono da revista Review $^{2}$, mas que podemos encontrar seu significado, a descrição de seu processo, já nos escritos do Manifesto Comunista ${ }^{3}$, de Marx e Engels, em 1848. De acordo com o verbete, exemplos de comodificação estão relacionados à socialização do trabalho feminino; à privatização de serviços governamentais, como educação, transporte público e rodovias, saúde, abastecimento de água; à comercialização de atividades científicas e culturais, sobretudo através de mecanismos de financiamento que as direcionam a interesses

\footnotetext{
${ }^{1}$ Encyclopedia of Marxism: https://www.marxists.org/glossary/terms/c/o.htm. Acesso em 28 de Fevereiro de 2018.

${ }^{2}$ Referência não encontrada e não indicada pela Encyclopedia of Marxism.

${ }^{3}$ MARX, Karl; ENGELS, Friedrich. Manifesto Comunista. São Paulo: Boitempo, 2007.
} 
comerciais e os direitos autorais; a patentes e direitos de propriedade intelectual, que são colocados em informações e conhecimentos do ramo da indústria, Ciência e Arte.

Com efeito, pela definição do verbete, e pelas conceituações de experiência vistas no capítulo anterior, parece que a experiência pode mesmo ser considerada uma mercadoria. Contudo, como a noção de comodificação ${ }^{4}$ entende mercadoria? O que seria exatamente uma mercadoria ${ }^{5}$ ? E por que os teóricos e profissionais do Campo do Design se opõem à comodificação da experiência, uma vez que parece evidente que as experiências são comodificadas, ou seja, projetadas para serem vendidas? Vamos tentar responder a essas perguntas neste trabalho, partindo de escritos que abarcam a discussão sobre mercadoria desde o século XIX — nosso ponto de origem - até a contemporaneidade. Sentimos a necessidade de um retorno temporal substancial, uma vez que grande parte dos textos de hoje sobre mercadoria — inclusive os que abordaremos aqui — partem de concepções daquela época. Entretanto, mesmo partindo de um ponto de origem único, alguns autores divergem. Portanto, faz-se necessário tentar compreender agora o que é uma mercadoria, já definida por um de nossos autores como "uma coisa intrincada, plena de sutilezas metafísicas e melindres teológicos."

\footnotetext{
${ }^{4}$ Faz-se necessário observar aqui que os termos mercantilização, comercialização, commoditização e comodificação são utilizados de forma cambiante pelos autores de que trataremos. Não vamos optar por um termo em específico, mas os empregaremos de acordo com o adotado pelo autor em questão.

${ }^{5}$ Podemos aqui também adicionar o significado apresentado pelo Dicionário Houaiss (2009) para o termo mercadoria. Segundo o verbete, mercadoria consiste de um substantivo feminino, relativo a qualquer produto (matérias-primas, gêneros, artigos manufaturados etc.) suscetível de ser comprado ou vendido. Pode ainda ser mercancia, negócio, comércio realizado entre mercadores, além da ocupação, a profissão de mercador; bem como uma carga de gêneros e objetos transportada por terra, mar ou ar.
}

${ }^{6}$ MARX, Karl. O Capital: crítica da economia política. Livro I: o processo de produção do capital. São Paulo: Boitempo, 2013. 


\section{1.}

\section{A forma elementar}

Cento e cinquenta e um anos separam os escritos ${ }^{7}$ de Karl Marx da nossa realidade. Entretanto, sua atualidade é latente. Marx elucida n'O Capital $^{8}$, a partir de uma crítica à Economia Política, o que é e como funciona uma mercadoria: sua raison d'être e consequências no modo de produção capitalista. E é sobretudo essa raison d'être e consequências que perduram até hoje — posto que o modo de produção capitalista é o que ainda rege a nossa sociedade, salvo algumas mudanças que veremos mais a frente - , tornando necessário investigarmos essa noção agora.

O ponto inicial de Marx (2013, p. 113) para compreender o modus operandi do capitalismo é a mercadoria: "a riqueza das sociedades nas quais reina o modo de produção capitalista aparece como uma 'enorme coleção de mercadorias', e a mercadoria individual, como sua forma elementar." O autor afirma que a mercadoria é um objeto externo, uma coisa que, por meio de suas propriedades, satisfaz necessidades humanas de qualquer tipo e que essas necessidades - sejam elas provenientes do estômago ou da imaginação — não alterna em nada a questão. Para ele, não interessa como a coisa satisfaz a necessidade humana, se diretamente, como meio de subsistência, isto é, como objeto de fruição, ou indiretamente, como meio de produção. Segundo David Harvey $\left(2013\right.$, p. 26) ${ }^{9}$, com quem contaremos como apoio na explicação de mercadoria para Marx, a ele interessa o simples fato de que as pessoas compram mercadorias - um ato fundador de como vivemos.

Marx (2013, p. 113) pondera que toda coisa útil deve ser considerada sob um duplo ponto de vista: o da qualidade e o da quantidade, e que cada uma dessas coisas é um conjunto de muitas propriedades que podem ser úteis sob diversos aspectos. Logo, para Marx (2013, p. 114), “descobrir esses diversos aspectos e, portanto, as múltiplas formas de uso das coisas é um ato histórico", bem como é também um ato histórico "encontrar as medidas sociais para a quantidade das coisas úteis, pois a diversidade das medidas das mercadorias resulta, em parte, da natureza diversa dos objetos a serem medidos e, em parte, da convenção."

\footnotetext{
${ }^{7}$ Consideramos aqui a primeira publicação d'O Capital, em 1867.

${ }^{8}$ Ver referência na nota 6.

${ }^{9}$ HARVEY, David. Para entender O Capital. São Paulo: Boitempo, 2013.
} 
Com efeito, Marx (2013, p. 114) afirma que a utilidade de uma coisa faz dela um valor de uso. Essa utilidade é condicionada pelas propriedades do corpo da mercadoria e não existe sem esse corpo - por isso, o próprio corpo da mercadoria deve ser entendido como um valor de uso ou um bem. Ainda, o autor afirma que esse valor de uso se efetiva apenas no uso ou no consumo da mercadoria e que, na sociedade do modo de produção capitalista, esses valores de uso constituem também os suportes materiais do valor de troca. Logo, Marx (2013, p. 114) define o valor de troca como uma relação quantitativa, a proporção na qual valores de uso de um tipo são trocados por valores de uso de outro tipo. Entretanto, essa relação se altera constantemente no tempo e no espaço e, por isso, o valor de troca - que tem de ser permutável com outros valores de troca, ou de mesma grandeza - algo acidental e relativo, aparece como algo intrínseco, imanente à mercadoria; portanto, uma "contradição nos próprios termos." Harvey (2013, p. 25) chama atenção para o uso do termo "aparece" presente aqui e em outras passagens d'O Capital, o que indica que uma coisa diferente acontece por trás da aparência superficial.

Por conseguinte, Marx (2013, p. 115) discorre que, como valores de uso, as mercadorias são de diferente qualidade; como valores de troca, elas podem ser apenas de quantidade diferente, sem conter "nenhum átomo de valor de uso". Mas o que faz com que todas as mercadorias sejam comensuráveis na troca, ou seja, que seus valores de troca expressem uma igualdade? Marx (2013, p. 115) ensina que essa igualdade não pode ser mais do que um modo de expressão, uma "forma de manifestação" de um conteúdo que pode ser distinguido dele mesmo. Conforme Harvey (2013, p. 27), não se pode dissecar uma mercadoria para encontrar nela própria aquilo que a torna intercambiável: o que a torna intercambiável tem de ser outra coisa, e essa outra coisa, segundo Marx (2013, p. 115), só pode ser descoberta quando a mercadoria é trocada. Pois quando ela troca de mãos, afirma Harvey (2013, p. 27), ela expressa não apenas algo que diz respeito às suas próprias qualidades, mas às qualidades de todas as mercadorias, uma vez que são comensuráveis entre si. Assim, Marx (2013, p. 115) conclui que cada uma das mercadorias, na medida em que é valor de troca, tem de ser redutível a uma terceira.

Essa terceira, Marx (2013, p. 115) postula que não pode ser uma propriedade geométrica, física, química ou qualquer outra propriedade natural das mercadorias, pois essas propriedades importam apenas na medida em que conferem utilidade às mercadorias, isto é, como valores de uso - assim, temos uma abstração dos valores 
de uso para caracterizar a relação de troca das mercadorias, pois nessa relação um valor de uso vale tanto quanto o outro, desde que esteja disponível em proporção adequada. Com efeito, Marx (2013, p. 116) arrazoa que "prescindindo do valor de uso dos corpos das mercadorias, resta nelas uma única propriedade, a de serem produtos do trabalho.” Logo, conforme Harvey (2013, p. 28), todas as mercadorias são produto do trabalho humano e o que elas têm em comum é que são suporte deste trabalho incorporado em sua produção.

Mas como definir, mensurar essa incorporação de trabalho nas mercadorias? Marx (2013, p. 116) escreve que não pode ser através do tempo efetivamente despendido no trabalho - o que ele chama de trabalho concreto - pois uma mercadoria seria, então, tanto mais valiosa quanto a duração da sua produção. Logo, resta que todas as mercadorias só podem ser reduzidas ao trabalho humano igual ou trabalho humano abstrato - e que deste trabalho não resta mais do que uma objetividade fantasmagórica, uma simples geleia de trabalho humano indiferenciado, dispêndio de força de trabalho sem consideração pela forma de seu dispêndio. Assim, Marx (2013, p. 116) explica o trabalho humano abstrato como o produto, o resultado do trabalho, que já aparece transformado em nossas mãos, pois se abstraímos o valor de uso, abstraímos também os componentes e as formas corpóreas que fazem dele um valor de uso. Logo, o produto não é mais uma casa, uma mesa, um fio ou qualquer outra coisa útil, pois todas as qualidades sensíveis são apagadas. Além disso, também não é mais o produto do pedreiro, do carpinteiro, do fiandeiro ou de qualquer outro trabalho produtivo determinado. Conforme o autor, desaparece o caráter útil dos trabalhos neles representados e, consequentemente, também as diferentes formas concretas desses trabalhos, que não mais se distinguem uns dos outros, sendo todos reduzidos a trabalho humano igual.

Portanto, Marx (2013, p. 117) postula que é apenas a quantidade de trabalho socialmente necessário ou o tempo de trabalho socialmente necessário para a produção de um valor de uso que determina a grandeza de seu valor - a mercadoria individual vale aqui somente como exemplar médio de sua espécie. Com efeito, para o autor, o valor de uma mercadoria está para o valor de qualquer outra mercadoria assim como o tempo de trabalho socialmente necessário para a produção de uma está para o tempo de trabalho socialmente necessário para a produção de outra. Entretanto, a grandeza de valor de uma mercadoria muda com 
cada mudança na força produtiva do trabalho: conforme Marx (2013, p. 118), essa força produtiva do trabalho é determinada por múltiplas circunstâncias, como o grau médio de destreza dos trabalhadores, o grau de desenvolvimento da ciência e de sua aplicabilidade tecnológica, a organização social do processo de produção, o volume e a eficácia dos meios de produção e as condições naturais. Harvey (2013, p. 28-29) complementa, afirmando que para compreender o que significa o dispêndio da mesma força de trabalho humana, é preciso olhar para a força de trabalho conjunta da sociedade, que se apresenta nos valores do mundo das mercadorias, invocando tacitamente um mercado mundial que foi introduzido pelo modo de produção capitalista. Assim, Harvey (2013, p. 29-31) considera que é nesse terreno global dinâmico de relações de troca que o valor é determinado e redeterminado continuamente.

Com efeito, Marx (2013, p. 116) considera que na própria relação de troca das mercadorias, seu valor de troca aparece então como algo completamente independente de seus valores de uso; e que, ao se abstrair o valor de uso dos produtos do trabalho, obteremos seu valor. Logo, o elemento comum que se apresenta na relação de troca ou valor de troca de mercadorias é seu valor. Com isso, Harvey (2013, p. 28) afirma que podemos reinterpretar o valor de troca como o modo necessário de expressão ou forma de manifestação do valor. Logo, o valor de troca consiste de uma representação necessária do trabalho humano incorporado nas mercadorias.

Em seguida, Harvey (2013, p. 30) retoricamente questiona: mas do que consiste o "socialmente necessário" do trabalho incorporado nas mercadorias? Como isso é estabelecido, e por quem? Quais são as necessidades sociais embutidas no modo de produção capitalista? O autor afirma que esses questionamentos devem ser feitos, uma vez que remetem à questão primordial sobre por quem e como os "valores" são estabelecidos, pois se queremos entender quem somos e qual é o nosso lugar, temos de começar entendendo como os valores das mercadorias são criados e produzidos e quais são suas consequências — sociais, ambientais, políticas etc.

Marx (2013, p. 118) prossegue e retoma a questão do valor de uso: uma coisa pode ser valor de uso sem ser valor, como quando sua utilidade para o homem não é mediada pelo trabalho - o ar, a terra virgem, os campos naturais, a madeira bruta etc. Também, uma coisa pode ser útil e produto do trabalho humano sem ser 
mercadoria, como quem, por meio de seu produto, satisfaz sua própria necessidade. Logo, para o autor, para produzir mercadoria faz-se necessário produzir não apenas valor de uso, mas valor de uso para outrem, valor de uso social: é preciso que o produto, por meio da troca, seja transferido a outrem, a quem vai servir como valor de uso. Além disso, Marx (2013, p. 119) complementa, nenhuma coisa pode ser valor sem ser objeto de uso. Assim, se ela é inútil, também o é o trabalho nela contido, não conta como trabalho e não cria, por isso, nenhum valor.

Neste ponto, Harvey (2013, p. 33) chama atenção a um ponto importante do pensamento de relações dialéticas de Marx: "podemos falar de valor de troca sem falar de valor de uso? Não. Podemos falar de valor sem falar de valor de uso? Não. Em outras palavras, não podemos falar de nenhum desses conceitos sem falar dos outros. Eles são mutuamente dependentes, são relações numa totalidade de determinado tipo.” E complementa, afirmando que Marx reconheceu que os valores de uso são incrivelmente diversos, os valores de troca são acidentais e relativos e o valor tem (ou parece ter) uma objetividade fantasmagórica, que está sujeita a perpétuas revoluções impostas por mudanças tecnológicas e reviravoltas nas relações sociais e naturais. Essa totalidade não é estática e fechada, mas fluida e aberta, portanto, em perpétua transformação. Assim, Harvey (2013, p. 36) postula que temos uma compreensão das relações internas que mantêm o capitalismo em perpétuo estado de unidade contraditória e, portanto, em perpétuo movimento.

Após a definição de mercadoria, Marx (2013, p. 124) parte para discutir o duplo caráter do trabalho representado nas mercadorias. $\mathrm{O}$ autor afirma que todo trabalho é, por um lado, dispêndio de força humana de trabalho em sentido fisiológico - dispêndio produtivo de cérebro, músculos, nervos, mãos etc. humanos - e graças a essa sua propriedade de trabalho humano igual ou abstrato ele gera o valor das mercadorias. Por outro lado, todo trabalho é dispêndio de força humana de trabalho numa forma específica, determinada à realização de um fim e, nessa qualidade de trabalho concreto e útil, ele produz valores de uso. Assim, segundo Harvey $(2013$, p. 38) os aspectos abstrato — homogêneo - e concreto heterogêneo - do trabalho são unificados no ato laboral unitário, isto é, uma mercadoria precisa de ambos para ocorrer. Harvey (2013, p. 38) ainda aponta uma importante distinção que Marx postula entre riqueza - o total de valores de uso sob o comando de alguém — e valor — o tempo socialmente necessário de trabalho que esses valores de uso representam. 
Harvey (2013, p. 39) afirma que quando trata da forma do valor, o objetivo de Marx (2013, p. 125-126) é explicar a origem da forma-dinheiro. Com efeito, o autor principia por postular que a relação mais simples de valor é, evidentemente, a relação de valor de uma mercadoria com uma única mercadoria distinta dela, não importando qual seja. Assim, o valor da primeira mercadoria se apresenta como valor relativo, ou encontra-se na forma de valor relativa, enquanto que a segunda mercadoria funciona como equivalente, ou encontra-se na forma de equivalente. Harvey $(2013$, p. 40) discorre que Marx quer mostrar que o ato de troca tem sempre um caráter duplo — os polos das formas relativa e equivalente - , no qual a mercadoria equivalente figura como incorporação de trabalho humano abstrato. Com efeito, a oposição entre valor de uso e valor, até aqui interiorizada na mercadoria, é representada, assim, por meio de uma oposição externa entre uma mercadoria que é um valor de uso e outra que representa seu valor na troca - e as mercadorias podem ter inúmeros equivalentes e relativos potenciais. Logo, uma complexidade cada vez maior entre as relações de troca produz o que Marx (2013, p. 145-146) chama de forma desdobrada de valor, a qual se converte numa forma universal de valor. E essa se cristaliza num equivalente universal, que consiste de uma mercadoria que desempenha o papel exclusivo de mercadoria-dinheiro. Com efeito, Marx (2013, p. 146) afirma que a mercadoria-dinheiro surge de um sistema de trocas, e não o precede, de modo que a proliferação e a generalização das relações de troca são a condição necessária, crucial, para a cristalização da formadinheiro.

Por conseguinte, Harvey (2013, p. 41) afirma que exatamente ao contrário da objetividade sensível e crua dos corpos das mercadorias, na objetividade do valor não está contido um único átomo de matéria natural. Por isso, para Marx (2013, p. 125), pode-se virar e revirar uma mercadoria como se queira e ela permanece inapreensível como coisa de valor. Com efeito, temos que o valor é imaterial, porém objetivo - o valor é uma relação social, e não podemos ver, tocar ou sentir diretamente as relações sociais; no entanto, elas têm uma presença objetiva. Assim, a forma-dinheiro faz-se necessária como meio de representação, meio tangível de expressão deste valor, pois é ela que faz do valor (como tempo de trabalho socialmente necessário) o regulador das relações de troca.

Deste modo, Marx (2013, p. 137) condensa as três peculiaridades da formadinheiro: "a oposição interna entre valor de uso e valor contida na mercadoria é 
representada por meio de uma oposição externa, isto é, pela relação entre duas mercadorias, sendo a primeira - cujo valor deve ser expresso - considerada imediata e exclusivamente como valor de uso, e a segunda - na qual o valor é expresso — imediata e exclusivamente como valor de troca.” Assim, o valor só existe em relações entre mercadorias e só pode ser expresso materialmente na forma da mercadoria-dinheiro.

Marx (2013, p. 146-148) adentra então a questão do caráter fetichista da mercadoria. Ele começa postulando que uma mercadoria aparenta ser, à primeira vista, uma coisa óbvia, trivial, mas que após sua análise, verificamos que ela é uma coisa "intrincada, plena de sutilezas metafísicas e melindres teológicos", conforme supracitado. Ele afirma que esse caráter enigmático surge da sua própria forma: a mercadoria reflete aos homens os caracteres sociais de seu próprio trabalho como caracteres objetivos dos próprios produtos do trabalho, propriedades sociais que são naturais a essas coisas, refletindo assim também a relação social dos produtores com o trabalho total como uma relação social entre os objetos, existente à margem dos produtores. Assim, verificamos que o fetichismo consiste justamente velando a força de trabalho existente por trás da mercadoria. Conforme Marx (2013, p. 146), a forma-mercadoria e a relação de valor dos produtos do trabalho em que ela se representa não tem absolutamente nada a ver com sua natureza física e com as relações materiais que dela resultam: é apenas uma relação social determinada entre os próprios homens que aqui assume a forma fantasmagórica de uma relação entre coisas. Esse fetichismo se cola aos produtos do trabalho tão logo eles são produzidos como mercadorias e, por isso, é inseparável da produção de mercadorias.

Segundo Harvey (2013, p. 46), isso acontece porque os produtores só travam contato social mediante a troca de seus produtos do trabalho, de modo que os caracteres especificamente sociais de seus trabalhos privados aparecem apenas no âmbito da troca mercantil. Assim, para os produtores, Marx (2013, p. 148-150) afirma que as relações sociais entre seus trabalhos privados aparecem como aquilo que elas são, isto é, não como relações diretamente sociais entre pessoas em seus próprios trabalhos, mas como relações reificadas entre pessoas e relações sociais entre coisas. O autor complementa, afirmando que a forma acabada - a formadinheiro - do mundo das mercadorias vela materialmente - em vez de revelar o caráter social dos trabalhos privados e as relações sociais entre os trabalhadores 
privados. Com efeito, Marx (2013, p. 154-156) postula que tais formas pertencem a uma formação social em que o processo de produção domina os homens, e não os homens o processo de produção, são consideradas como uma necessidade natural tão evidente quanto o próprio trabalho produtivo. Segundo Harvey (2013, p. 53), em sistemas altamente complexos de troca, é impossível conhecer a atividade dos trabalhadores e é isso que torna o fetichismo inevitável no mercado mundial. Logo, para Marx (2013, p. 150), as forças do mercado, que ninguém controla individualmente, regulam todos nós.

Quanto à esfera da troca, Marx (2013, p. 159-160) afirma que as mercadorias não podem ir por si mesmas ao mercado e trocar-se umas pelas outras - alguém o faz. Assim, as pessoas existem umas para as outras apenas como representantes da mercadoria e, por conseguinte, como possuidoras de mercadorias, através de máscaras econômicas que não passam de personificações das relações econômicas.

Conforme Marx (2013, p. 160), para o possuidor de mercadorias, sua mercadoria não tem nenhum valor de uso imediato - do contrário, ele não a levaria ao mercado. Para ele, o único valor de uso que ela possui diretamente é o de ser suporte de valor de troca, ou seja, meio de troca. Portanto, elas precisam universalmente mudar de mãos - sua troca - e essa troca as relaciona umas com as outras como valores e as realiza como valores. Por isso, as mercadorias têm de se realizar como valores antes que possam se realizar como valores de uso, ou seja, elas têm de ser passíveis de serem trocadas, têm de ter valor de troca. Entretanto, para terem valores de troca, elas também precisam ser valores de uso, pois o trabalho humano que nelas é despendido só conta na medida em que seja despendido numa forma útil para outrem - e isso só a troca pode demonstrar. Assim, Marx (2013, p. 162) afirma que se confirma a separação entre a utilidade das coisas para a necessidade imediata e sua utilidade para troca.

Segundo Harvey (2013, p. 54), até aqui conhecemos apenas a função do dinheiro como forma de manifestação do valor das mercadorias ou como o material no qual as grandezas de valor das mercadorias se expressam socialmente. Para Marx (2013, p. 164-165), a forma-dinheiro é apenas o reflexo, concentrado numa única mercadoria, das relações de todas as outras mercadorias - a forma-dinheiro da coisa é externa a ela mesma, não sendo mais do que a forma de manifestação de relações humanas que se escondem por trás dela. Com efeito, Harvey (2013, p. 58) 
afirma que, portanto, o enigma do fetiche do dinheiro não é mais do que o enigma do fetiche da mercadoria, que agir se torna visível e ofusca a visão.

Quanto à troca de mercadorias, Marx (2013, p. 162) afirma que uma mercadoria está "sempre pronta a trocar não apenas sua alma, mas seu corpo com qualquer outra mercadoria." Para o autor, essa economia de trocas mercantis implica que estamos lidando com "proprietários privados" de "coisas alienáveis" e isso, por sua vez, implica que temos "pessoas independentes umas das outras." Conforme Harvey (2013, p. 57), "alienáveis" refere-se ao fato de que as coisas são, em si mesmas, exteriores ao homem, isto é, livremente cambiáveis - e isso significa que os operadores da troca não têm nenhum vínculo pessoal com as coisas que possuem.

Imbricado ao processo de troca está o meio de circulação das mercadorias, ou a sua metamorfose. Marx (2013, p. 178) afirma que na medida em que o processo de troca transfere mercadorias das mãos em que elas não são valores de uso para as mãos em que elas são valores de uso, esse processo deve ser entendido como um metabolismo social, afinal, as mercadorias nada mais são do que resultado do trabalho humano. Ele explica que o processo de troca gera uma duplicação da mercadoria em mercadoria e dinheiro, uma antítese externa na qual elas expressam sua antítese imanente entre valor de uso e valor. Nessa antítese, as mercadorias, como valores de uso, confrontam-se com o dinheiro, como valor de troca.

Com efeito, o processo de troca da mercadoria se consuma, portanto, em duas metamorfoses contrapostas e mutuamente complementares: a conversão da mercadoria em dinheiro e reconversão do dinheiro em mercadoria, que Marx (2013, p. 179) nomeia M-D-M, uma dupla metamorfose do valor: de $M$ em D e de D em M. Esses momentos são simultaneamente transações dos possuidores de mercadorias - venda, troca da mercadoria por dinheiro; compra, troca do dinheiro por mercadoria - e a unidade dos dois atos: vender para comprar. Neste sentido, a troca é uma transação em que o valor sofre uma mudança de forma.

Harvey (2013, p. 69) afirma que, superficialmente, essas formas do valor parecem imagens refletidas num espelho, portanto equivalentes em princípio; mas, na verdade, elas são assimétricas: o lado M-D da troca, a venda, implica a mudança de forma de uma mercadoria particular em seu equivalente universal, a mercadoriadinheiro; já o lado D-M da troca, a compra, é a transição do dinheiro para a mercadoria; ele realiza um movimento do universal para o particular. Marx (2013, 
p. 184-185) considera esses movimentos como duas mutações antitéticas da mercadoria, que se realizam em dois processos sociais antitéticos do possuidor de mercadorias: como a mesma mercadoria percorre sucessivamente as duas mutações inversas, assim o mesmo possuidor de mercadorias desempenha alternadamente os papéis de vendedor e comprador.

Com efeito, Harvey (2013, p. 70) postula que a ênfase de Marx nas antíteses sinaliza uma contradição na metamorfose das mercadorias tomadas em conjunto: a mercadoria é ao mesmo tempo um não valor de uso para o proprietário e, como objeto de compra, um valor de uso para o comprador. Assim, conforme Marx (2013, p. 181-182), os possuidores de mercadorias descobrem que a mesma divisão do trabalho que os transforma em produtores privados independentes também torna independente deles o processo social de produção e suas relações nesse processo, e que a independência das pessoas umas das outras se consuma num sistema de dependência material universal. Com efeito, Marx (2013, p. 186) afirma que, por um lado, a troca de mercadorias rompe as barreiras individuais e locais da troca direta de produtos e desenvolve o metabolismo do trabalho humano e, por outro, desenvolve um círculo completo de conexões que, embora sociais, impõem-se como naturais, não podendo ser controladas por seus agentes.

E como é definido o preço da mercadoria, isto é, a quantidade de dinheiro pela qual a trocaremos? Marx $(2013$, p. 181) afirma que a resposta está no expoente de sua grandeza de valor: se foi despendida somente a média socialmente necessária de tempo de trabalho, o preço será apenas a denominação monetária da quantidade de trabalho social nela objetivado. Ainda, o autor considera que não se percebe no dinheiro de que qualidade é a mercadoria que foi nele transformada: "em sua formadinheiro, uma mercadoria tem a mesma aparência que a outra." (MARX, 2013, p. 183)

Harvey (2013, p. 70-71) afirma que esse processo — a circulação de mercadorias - é cada vez mais mediado pelo dinheiro, pois ao contrário de uma mercadoria comprada, que sendo um valor de uso para o consumidor pode "sair de circulação", o dinheiro não desaparece. Ele continua a se movimentar e de tal modo que, conforme Marx (2013, p. 186) "a circulação transpira dinheiro por todos os poros."

Por fim, para Marx (2013, p. 180), a divisão do trabalho consiste de um organismo natural-espontâneo da produção, cujos fios foram e continuam a ser 
tecidos pelas costas dos produtores de mercadorias. Logo, talvez a mercadoria seja o produto de um novo modo de trabalho, que se destina à satisfação de uma necessidade recém-surgida ou pretende ela própria engendrar uma nova necessidade. Para o autor, o que era ontem uma função entre muitas de um mesmo produtor de mercadorias, hoje pode gerar uma nova modalidade particular de trabalho, que separada desse conjunto manda seu produto ao mercado como mercadoria independente.

Deste modo, faz-se mister agora compreendermos o desdobramento histórico da mercadoria, isto é, que novas formas de trabalho e novas mercadorias surgiram a partir do movimento dinâmico do modo de produção capitalista descrito por Marx. Entretanto, antes de avançarmos, alguns comentários fazem-se necessários. Primeiro, vimos pela explanação acima a importância que o trabalho e a esfera da produção têm para a conceituação e o funcionamento da noção de mercadoria. Por restrições de tempo e espaço, não abordaremos a dimensão do trabalho aqui, salvo através de alguns comentários e trechos essenciais para o entendimento do que discutimos. Segundo, já podemos começar a pensar: a experiência no Campo do Design se encaixa na definição de mercadoria de Marx? Ela não é algo externo ao homem, nem possui propriedades físicas. Ainda, uma experiência tem uma utilidade específica? Como poderíamos mensurar sua qualidade e quantidade? E em que consiste o trabalho de $\operatorname{produzir}^{10}$ uma experiência?

\section{2 .}

\section{Metamorfoses históricas}

Obviamente que o mundo hoje é diferente do mundo que Marx descreveu. Muitas coisas mudaram - muitas mudanças mais rápidas do que podemos acompanhar , mas outras - curiosamente - se mantêm, por vezes transvestidas com outro nome ou outra aparência. $\mathrm{O}$ entendimento de mercadoria parece ser uma dessas coisas que não cambiaram. Entretanto, para vislumbrarmos e entendermos as mudanças que ocorreram, temos que olhar não apenas para as mercadorias em si,

\footnotetext{
${ }^{10}$ Atentamos aqui para o uso do termo produzir, e não projetar.
} 
mas também para aquilo que as forma: as mudanças ocorridas no movimento dialético entre sociedade e o modo de produção capitalista.

Uma das principais discussões acerca do que aqui nomeamos Metamorfoses Históricas é a aproximação das práticas culturais e artísticas às regras econômicas — ou melhor, a subsunção das primeiras às últimas. O Campo do Design encontrase nesta seara, posto que tem sua gênese na Revolução Industrial ${ }^{11}$, na virada do século XVIII para XIX, como prática profissional orientada para a configuração e criação de produtos. Alguns dos textos que abordaremos não são recentes Adorno e Horkheimer, por exemplo, escreveram em 1944; Mandel e Harvey, na década de 1980. Ainda que alguns exemplos e colocações possam parecer ultrapassados, faz-se necessário tratarmos deles pois, se queremos um fio condutor claro de como chegamos até aqui, necessitamos deste caminho ao passado com dados/fatos tanto superados quanto aqueles que se mantêm - por vezes, como assombrações.

\section{2.1. \\ Industrializando o sensível}

Theodor W. Adorno (1903-1969) e Max Horkheimer (1895-1973) iniciam seu texto A Indústria Cultural: o esclarecimento como mistificação das massas ${ }^{12}$ afirmando que toda cultura de massa sob monopólio é idêntica e que os contornos do seu esqueleto, ou sua armadura conceitual, torna-se evidente. ${ }^{13}$ Para Adorno e Horkheimer (2002, p. 94-95), práticas culturais tornam-se negócios, se

\footnotetext{
${ }^{11}$ Seguindo o pensamento de Adrian Forty. Ver referência na nota 5 do Capítulo 2 - Da experiência.

${ }^{12}$ Citamos o título da versão em português, mas usamos como base para este escrito a versão em inglês: ADORNO, Theodor W.; HORKHEIMER, Max. Dialectic of Enlightenment: Philosophical Fragments. Stanford University Press, 2002.
}

13 Adorno e Horkheimer costumam ser criticados por apresentarem o que é considerado um tom elitista em seu texto, por julgarem a indústria da cultura de massa como uma produção inferior. Nós não entraremos neste mérito, pois o que nos interessa aqui é compreender como eles conceituaram essa aproximação do mercado com a Arte, mais precisamente no que concerne ao entendimento das mercadorias. Enquanto essa subsunção da Arte ao mercado tem para eles um tom de lamentação, para nós consiste de um conjunto de fatos históricos concretos a serem examinados e entendidos sem enaltecimento de um passado supostamente melhor. Ainda, o escrito com o qual trabalhamos aqui é cheio de aforismos, o que torna um pouco complexa a tarefa de explicá-lo sem quebras abruptas, mas tentaremos. 
autointitulam indústrias e os números que atestam os rendimentos de seus diretores eliminam dúvidas sobre a real necessidade social de seus produtos. Eles afirmam que as partes interessadas gostam de explicar a indústria cultural em termos técnicos, argumentando que seus milhões de participantes demandam processos de reprodução que inevitavelmente levam ao uso de produtos estandardizados para cumprirem as necessidades em distintas localidades - e não o contrário, que tal sistema tenha sido imposto em virtude de interesses econômicos hegemônicos. Com efeito, eles complementam que a antítese entre poucos centros de produção e uma recepção amplamente dispersa requer organização e planejamento por parte daqueles em controle.

Adorno e Horkheimer (2002, p. 95) escrevem que as partes interessadas também justificam as formas estandardizadas como originalmente derivadas das necessidades dos consumidores. Entretanto, eles afirmam que, na realidade, um ciclo de manipulação e necessidade retroativa é o que unifica o sistema, pois o que sustenta o poder da tecnologia diante da sociedade é o poder daqueles cuja posição econômica na sociedade é mais alta. "A racionalidade técnica hoje é a racionalidade da dominação", defendem Adorno e Horkheimer (2002, p. 95). Por conseguinte, eles consideram que efeitos adversos dessa situação não devem ser atribuídos às leis internas da tecnologia, mas sim à sua função dentro da economia diferentemente de como ocorre até hoje, em que termos técnicos são erroneamente utilizados como causa e solução para problemas econômicos. Ainda, Adorno e Horkheimer (2002, p. 96) discorrem sobre a dependência das empresas de radiodifusão e de filmes, por exemplo, das indústrias elétricas e dos bancos, o que caracteriza toda uma esfera cujos setores individuais estão interligados economicamente - e o que faz a indústria cultural se submeter aos ditames de gigantes econômicos.

Os autores postulam que a mentalidade do público — a qual eles consideram favorecer o sistema da indústria cultural - é uma parte do sistema e não uma desculpa para a sua existência; e que entre os executivos há uma determinação comum de não aprovarem ou produzirem nada que não esteja de acordo com suas diretrizes e com seu conceito de consumidor — atentamos aqui já para a ideia falaciosa de um consumidor, no Design, "usuário", ideal. Ainda, Adorno e Horkheimer (2002, p. 97) discorrem sobre uma hierarquia de qualidades que serve apenas para quantificar o público mais ainda: todos devem se comportar 
espontaneamente de acordo com um "nível" determinado por índices e devem selecionar categorias de produtos em massa fabricados para o seu tipo. Nos gráficos das organizações de pesquisa ${ }^{14}$ — que eles consideram indistinguíveis daqueles orientados à propaganda política — os consumidores são divididos em material estatístico composto por áreas em vermelho, verde ou azul, de acordo com sua renda.

Além disso, Adorno e Horkheimer (2002, p. 97) evidenciam as semelhanças dos produtos - fornecem o exemplo de carros, mas hoje poderíamos falar dos celulares - e que listas de vantagens e desvantagens debatidas por entusiastas servem apenas para perpetuar a aparência de competição e escolha, quando na verdade essas possibilidades de competição e escolha são pequenas, senão nulas. Deste modo, Adorno e Horkheimer (2002, p. 98) postulam que vivemos em uma "sociedade irracional, apesar de toda a sua racionalização."

Quanto à relação entre forma e conteúdo na produção da indústria cultural, Adorno e Horkheimer (2002, p. 99-101) afirmam que essa se desenvolveu em conjunção com a predominância do efeito, do detalhe técnico, e que estes são postos acima da ideia, a qual teria sido liquidada. Para os autores, o poder da sociedade industrial está impresso nas pessoas de uma vez por todas, pois todos os produtos da indústria cultural tornaram-se tão relevantes que esses acabam sendo consumidos até mesmo em estado de distração. Ainda, eles consideram a tradução rotineira de tudo - mesmo do que ainda não foi pensado - ao esquema da reprodutibilidade mecânica ${ }^{15}$, o que recai em uma naturalização da indústria cultural, com a tecnologia reduzindo a tensão entre o produto cultural e a existência cotidiana.

Adorno e Horkheimer (2002, p. 102) discorrem ainda sobre a reputação do especialista - no caso deles, um profissional de erudição ${ }^{16}$-, no qual enxergam um último resíduo de autonomia, mas que na colisão com a política empresarial da

\footnotetext{
14 Conforme veremos mais à frente com Mandel (1982), novas iniciativas econômicas do capitalismo tardio.

15 Aqui lembramos de Walter Benjamin, um pensador influente na Escola de Frankfurt. Ver referência na nota 97 do Capítulo 2 - Da experiência.

16 Porém, devemos lembrar também que, grosso modo, na linha de produção, por exemplo, é justamente a especialização um dos fatores que mais aliena.
} 
indústria acaba por produzir a mercadoria da cultura — entretanto, eles não definem aqui o que consideram essa mercadoria da cultura.

Sobre estilo, Adorno e Horkheimer (2002, p. 102-104) postulam que a indústria cultural é tanto a negação quanto um estilo ela própria. Primeiro: é negação uma vez que a reconciliação do geral e do particular, das regras e das demandas específicas do sujeito, através dos quais o estilo adquire substância, é anulado na ausência da tensão entre os polos, como um equivalente ao poder. Segundo: a indústria da cultura só pode ser um estilo, pois apenas o que foi industrializado, rigorosamente subsumido, pode estar totalmente adequado a este conceito de cultura - que identifica, classifica e cataloga e que é imposto cotidianamente e sistematicamente aos nossos sentidos. Assim, ela divulga seu segredo: a obediência a uma hierarquia social e às leis gerais do capital. Logo, a indústria da cultura, o estilo mais flexível de todos, prova ser o objetivo do liberalismo, que é criticado justamente por uma falta de estilo. Com efeito, Adorno e Horkheimer (2002, p. 104-106) afirmam que não apenas as categorias e conteúdos da indústria cultural são originados na esfera liberal, em um naturalismo domesticado, mas também que qualquer um só sobrevive se for incorporado. Assim, qualquer um que não se conforma é condenado a uma impotência econômica que é prolongada na impotência intelectual, sendo convencido de inadequação.

Adorno e Horkheimer (2002, p. 107) consideram que o entretenimento e outros elementos da indústria cultural já existiam muito antes da indústria ela mesma. Entretanto, é com a indústria cultural que esses são elevados e ela pode, então, se vangloriar de ter energeticamente enaltecido a por vezes inepta transposição da Arte à esfera do consumo: de ter tirado o entretenimento de suas ingenuidades e melhorado a qualidade de suas mercadorias - novamente, não evidenciam aqui seu entendimento de mercadoria. Com efeito, os autores afirmam que o que é novo, então, é que os elementos irreconciliáveis da cultura, da arte e do entretenimento foram igualmente sujeitados ao conceito de propósito e, assim, trazidos a um único falso denominador: o da totalidade da indústria da cultura, cujo principal elemento é a repetição. Para Adorno e Horkheimer (2002, p. 108), o fato de que as inovações características da indústria cultural são em todos os casos meros aumentos na produção em massa não é estranho ao sistema: seu controle de consumidores é mediado por essa produção em massa de entretenimento. 
Adorno e Horkheimer (2002, p. 109) postulam que a ideologia da indústria cultural é um negócio (business) e que o entretenimento é o prolongamento do trabalho sob o capitalismo tardio. ${ }^{17}$ Logo, o poder da indústria cultural está na sua unidade com as denominadas necessidades fabricadas — os objetos de desejo, bens materiais e imateriais com valor de uso social - não simplesmente em uma antítese a elas. Conforme os autores, a produção da indústria da cultura é procurada por aqueles que querem escapar do processo de trabalho mecanizado, para que possam lidar com ele novamente no dia seguinte. Contudo, ao mesmo tempo, eles consideram que a mecanização tem um poder tão grande sobre o lazer e a felicidade, determina tão completamente a fabricação de mercadorias do entretenimento, que o trabalhador de folga pode experienciar somente imagens posteriores ao processo de trabalho em si - aqui, os autores discorrem no sentido de que só vemos reproduções, e não obras autênticas. Com efeito, Adorno e Horkheimer (2002, p. 111) criticam a ideia de direcionar capacidades técnicas para fomentar o consumo de massa de bens em um sistema econômico que se recusa a utilizar essas capacidades com a mesma veemência quando a questão é abolir a fome.

Por conseguinte, Adorno e Horkheimer (2002, p. 111-113) afirmam que a indústria cultural engana seus consumidores com suas promessas: a promessa de prazer emitida pela embalagem, por exemplo, é prolongada, mas não se realiza. Assim, a indústria cultural não sublima: ela suprime; além de substituir a dor com a negação jovial. Os autores consideram que a indústria cultural trabalha a partir da necessidade - inerente ao sistema - de nunca deixar o consumidor suspeitar que há espaço para a resistência. Este princípio exige que todas as necessidades devem ser apresentadas aos indivíduos como capazes de serem realizadas pela indústria da cultura - ela produz, controla e disciplina as necessidades dos consumidores - e os indivíduos devem suprir suas necessidades apenas como consumidores eternos, como objetos da indústria cultural. Os autores afirmam que isso não só os persuade de que a fraude da indústria cultural é satisfação; como também dá a entender que eles devem se contentar com o que é oferecido, seja lá o que for.

Adorno e Horkheimer (2002, p. 114-117) consideram que a indústria cultural nega o peso do trabalho, fazendo o entretenimento significar deixar as coisas de lado, esquecer o sofrimento, mesmo quando estes estão em exibição; e

17 Jameson (1997, p. 22) afirma que foi a Escola de Frankfurt que primeiro utilizou o termo capitalismo tardio. 
que a ideologia se esconde nos cálculos de probabilidade utilizados na fabricação deste entretenimento e seus consumidores. Com efeito, os autores afirmam que para os planejadores, a indústria da cultura funciona como um álibi, fornecendo a impressão de que na rede de transações e medidas na qual a vida se transformou ainda há espaço para relação espontâneas e imediatas entre seres humanos.

Para Adorno e Horkheimer (2002, p. 118-120), a indústria cultural está interessada nos seres humanos apenas como seus consumidores e empregados. Dependendo do aspecto considerado primordial no momento, a ideologia enfatiza ou o plano ou a chance, ou a tecnologia ou a vida, ou a civilização ou a natureza. Como trabalhadores, as pessoas são lembradas da organização racional e devem se encaixar em seus requerimentos de bom senso; já como consumidores, eles são relegados, seja na tela ou no impresso, com histórias de interesse humano que demonstram a sua suposta liberdade de escolha. Em ambos os casos - como esse "direito à escolha" é apenas imaginado —, os trabalhadores e consumidores continuam sendo objetos da indústria cultural e, deste modo, os autores afirmam que a luta da indústria cultural é travada contra um inimigo que eles já consideram derrotado, o sujeito pensante - neste sentido, podemos pensar em um usuário pensante no Campo do Design?

Com efeito, Adorno e Horkheimer (2002, p. 121) consideram que para afirmar suas posições as pessoas mantêm em movimento uma economia em que o desenvolvimento extremo da tecnologia tornou supérfluas as massas de produtores em seus próprios países. De acordo com a ilusão ideológica, os trabalhadores, os verdadeiros provedores, são alimentados pelos líderes da indústria, a quem alimentam - logo, a posição do indivíduo torna-se precária. Os autores afirmam que a provisão gerenciada de cuidados amigáveis ${ }^{18}$, administrada pelas fábricas como um meio de aumentar a produção, traz o último impulso privado sob controle social: ao ser dada a aparência do imediatismo, as relações das pessoas dentro da produção são devolvidas à esfera privada.

Adorno e Horkheimer (2002, p. 124-126) consideram que não é apenas a padronização do modo de produção da indústria cultural que torna o indivíduo ilusório em seus produtos: com a indústria cultural, o traço individual é reduzido à

\footnotetext{
${ }^{18}$ Lembramos aqui dos escritórios do Google, que pretendem unir trabalho e diversão para seus empregados. Ver: www.nytimes.com/2013/03/16/business/at-google-a-place-to-work-andplay.html. Acesso em 3 de Março de 2018.
} 
capacidade do universal tão completamente para moldar o acidental que esse traço acaba sendo reconhecido como acidental. Com efeito, a peculiaridade do eu tornase uma mercadoria de monopólio socialmente condicionada e deturpada como natural. Conforme os autores, o indivíduo carrega a mancha da sociedade: na sua aparente liberdade, ele é produto do aparato econômico e social da sociedade aqui, impera também sobretudo o gosto dominante, o qual, segundo os autores, deriva seu ideal da propaganda, da beleza mercantilizada.

Retomando a questão do propósito, Adorno e Horkheimer (2002, p. 127128) consideram que a falta de propósito da grande obra de arte moderna é sustentada pelo anonimato do mercado - uma falta de propósito para fins ditados pelo mercado. Assim, os autores consideram que na demanda por entretenimento e relaxamento das pessoas que precisam trabalhar para viver, o propósito finalmente consumiu o reino do sem propósito. Mas como a demanda pela comercialização da Arte se torna total, uma mudança na composição econômica interna das mercadorias culturais se torna aparente. Conforme os autores, ao se adaptar inteiramente à necessidade - $\mathrm{o}$ incremento do valor de troca comercial em detrimento do valor de uso - , a obra de arte desfalca os seres humanos antes da libertação do princípio de utilidade que supostamente causa. Com efeito, o que pode ser chamado de valor de uso na recepção de bens culturais acaba sendo substituído pelo valor de troca - o prazer dá lugar ao estar lá e estar sabendo. O consumidor se torna a ideologia da indústria do entretenimento, de cujas instituições ele ou ela não pode escapar.

Por conseguinte, Adorno e Horkheimer (2002, p. 127-128), afirmam que tudo tem valor apenas na medida em que pode ser trocado, não na medida em que é algo em si mesmo. Logo, para os consumidores, o valor de uso da arte, sua essência, é um fetiche, e o fetiche - para os autores, a avaliação social que eles confundem com o mérito das obras de arte - torna-se seu único valor de uso, a única qualidade de que eles desfrutam. Desta forma, o caráter de mercadoria da arte se desintegra assim como é plenamente realizado: a arte torna-se uma espécie de mercadoria, trabalhada e adaptada à produção industrial, vendável e permutável; mas a Arte como espécie de mercadoria que existe para ser vendida, mas não à venda, torna-se inviável logo que a transação comercial não é mais apenas a sua intenção, mas o seu único princípio. Nesta querela, Adorno e Horkheimer (2002, p. 130) afirmam que mesmo quando o mercado da Arte estava apenas iniciando - 
eles não definem aqui o que consideram o início do mercado da Arte - o valor de uso não era arrastado como um mero apêndice pelo valor de troca, mas sim desenvolvido como uma condição prévia do último, ao benefício social de obras de arte.

Com efeito, Adorno e Horkheimer (2002, p. 131) afirmam que a cultura é uma mercadoria paradoxal: ela está tão completamente sujeita à lei da troca que não é mais trocada; é tão cegamente equiparada com o uso que não pode mais ser usada e, por este motivo, ela se funde com a propaganda. Logo, quanto mais sem sentido parece o uso sob monopólio, mais onipotente torna-se a cultura - e seus motivos são econômicos o bastante.

Os autores passam, então, a discorrer sobre a publicidade. Adorno e Horkheimer (2002, p. 131) postulam que a publicidade é o elixir da vida, mas porque o produto incessantemente diminui o prazer que promete como uma mercadoria, ele finalmente coincide com o anúncio do qual precisa em função da sua própria incapacidade de agradar. Logo, aqueles que controlam o sistema estão se entrincheirando na publicidade e isso fortalece o vínculo que garimpa os consumidores: conforme os autores, a publicidade realiza um serviço social ao orientar o comprador no mercado, facilitando a escolha e ajudando o fornecedor mais eficiente, mas desconhecido, a encontrar consumidores. Com efeito, a propaganda tornou-se um princípio negativo, um dispositivo de bloqueio: qualquer coisa que não tenha seu selo de aprovação acaba sendo economicamente suspeita. Adorno e Horkheimer (2002, p. 132) afirmam ainda que o caráter de montagem da indústria da cultura, o sintético, o modo controlado em que seus produtos são montados - como uma fábrica não só no estúdio de cinema, mas também, praticamente, na compilação de biografias baratas, romances jornalísticos, e canções de sucesso - predispõe essa indústria à publicidade: o momento individual, ao ser destacável, substituível, é distanciado mesmo tecnicamente de qualquer coerência de significado.

Em seguida, Adorno e Horkheimer (2002, p. 132-133) consideram que a publicidade e a indústria da cultura estão se fundindo tecnicamente tanto quanto economicamente: em ambas, o mesmo aparece em inúmeros lugares, a repetição mecânica do mesmo produto cultural já é o mesmo slogan de propaganda e, sob o ditado da eficácia, a técnica está se tornando psicotécnica, um procedimento para manipular, persuadir seres humanos - chamamos atenção aqui para o uso do termo 
eficácia e para a ideia de uma técnica psicotécnica, ambos presentes também no discurso sobre a experiência no Campo do Design.

Por fim, Adorno e Horkheimer (2002, p. 135-136) afirmam que a linguagem e os gestos dos ouvintes e dos espectadores estão profundamente permeados pelos padrões da indústria cultural. Para eles, as reações mais íntimas dos seres humanos tornaram-se tão reificadas que a ideia de algo peculiar a eles sobrevive apenas em abstração extrema: a personalidade dificilmente significa mais do que dentes brancos deslumbrantes e a ausência de odor e emoções corporais. Para os autores, esse é o triunfo da publicidade na indústria da cultura: a compulsiva imitação por consumidores de bens/mercadorias culturais que, ao mesmo tempo, eles reconhecem como falsas.

A descrição deste zeitgeist por Adorno e Horkheimer nos permite vislumbrar os motivos concretos que os fizeram nomear uma "indústria da cultura" ou "indústria cultural" e a considerar que os produtos desenvolvidos nesta indústria são mercadorias. Entretanto, não fica claro aqui o que eles consideram uma mercadoria - parece ser apenas algo que gera lucro. A eles importa mais discutir a consequência de objetos de Arte e Cultura como mercadorias, ou a tomada de esferas da vida pelo capitalismo - e neste sentido, a experiência é apresentada como mercadoria.

Uma das críticas posta a essa concepção de Adorno e Horkheimer é que eles consideram a esfera da circulação, e não necessariamente a esfera da produção, para definir isso que seria mercadoria. Assim, partimos agora para um entendimento mais próximo da esfera da produção, os escritos de Harvey e Mandel acerca da expansão do setor dos serviços, da "sociedade do consumo" e da realização do mais-valor no capitalismo tardio.

\subsection{2.}

\section{Novos modos de acumulação}

Não carece aqui nos alongarmos com explicações detalhadas sobre mudanças estruturais no capitalismo. Não obstante este seja um tema de importância para a investigação desta tese - uma vez que essas mudanças influenciam e influenciaram a condição e posição nas quais nos encontramos hoje necessitaremos, aqui, apenas de linhas gerais para localizar e determinar nosso 
ponto de partida, sobretudo no que concerne novos modos de acumulação de capital. Com efeito, antes de discorrermos sobre a expansão do setor de serviços no capitalismo e como este abre espaço para o questionamento acerca do que é mercadoria hoje, precisamos compreender algumas mudanças que ocorreram na forma de trabalho, posto que essas foram fundamentais para a expansão do setor de serviços.

Harvey escreveu o livro Condição pós-moderna: uma pesquisa sobre as origens da mudança cultural ${ }^{19}$ em 1989. Neste livro, o autor afirma que o longo período de expansão do pós-guerra — que se estendeu de 1945 a 1973 — teve como base um conjunto de práticas de controle do trabalho, tecnologias, hábitos de consumo e configurações de poder político-econômico, e de que esse conjunto pode com razão ser chamado de fordista-keynesiano, seguindo o modelo de produção em massa de Henry Ford (1863-1947) e a doutrina do Estado de Bem-Estar Social de John Maynard Keynes (1883-1946). Entretanto, o colapso desse sistema a partir da década de 1970 iniciou um período de rápida mudança, de fluidez e de incerteza. Para Harvey (2010, p. 119), os novos sistemas de produção e de marketing, caracterizados por processos de trabalho e mercados mais flexíveis, de mobilidade geográfica e de rápidas mudanças práticas de consumo, não garantem o título de um novo regime de acumulação; nem a virada cultural para o pós-modernismo garante o título de um novo modo de regulamentação ou regime cultural. Contudo, Harvey (2010, p 119) também considera que os contrastes entre as práticas políticoeconômicas da atualidade e as do período de expansão do pós-guerra são significativos para abraçarmos a hipótese de uma passagem do fordismo para o que poderia ser chamado regime de acumulação "flexível”. Assim, Harvey (2010, p. 142) postula que a crise do fordismo enquanto regime de acumulação evidenciou como principais sinais de esgotamento econômico a rigidez de longo termo e de larga escala dos investimentos de capital fixo nos sistemas de produção em massa e a rigidez nos mercados, alocação e contratos de trabalho, os quais expressavamse economicamente na elevação constante das taxas de inflação e de desemprego e na queda das taxas de crescimento econômico. Com efeito, em face da necessidade do capital transnacional de superar essas condições, Harvey (2010, p. 147) afirma que ocorreu a configuração de um novo regime de acumulação: a acumulação

${ }^{19}$ HARVEY, David. Condição pós-moderna: uma pesquisa sobre as origens da mudança cultural. São Paulo: Edições Loyola, 2010. 
flexível, que corresponde a uma flexibilidade de processos de trabalho, mercados de trabalho, produtos e padrões de consumo. ${ }^{20}$

Harvey (2010, p. 148) afirma que esses sistemas de produção flexível permitiram uma aceleração do ritmo da inovação do produto, além da exploração de nichos de mercado especializados e de pequena escala - ao mesmo tempo em que dependeram dessas mudanças. $\mathrm{O}$ tempo de giro foi reduzido de modo dramático pelo uso de novas tecnologias produtivas, como a automação, e de novas formas organizacionais, como o sistema de gerenciamento de estoques "just-in-time", o qual corta substancialmente a quantidade de material necessária para manter a produção. Entretanto, para o autor, a aceleração do tempo de giro na produção teria sido inútil sem a redução do tempo de giro no consumo. Logo, Harvey (2010, p. 148) afirma que a meia-vida de um produto fordista típico diminuiu em mais da metade em certos setores, como o têxtil e do vestuário, e as chamadas indústrias de "thoughware", como videogames e programas de computador. Com efeito, Harvey (2010, p. 148) considera que a acumulação flexível foi acompanhada por um crescimento do consumo, por uma atenção maior às modas fugazes e pela mobilização de artifícios de indução de necessidades e de transformação cultural. Ele afirma que a estética relativamente estável do modernismo fordista cedeu lugar à instabilidade e qualidades fugidias de uma estética pós-moderna que celebra a diferença, a efemeridade, o espetáculo, a moda e a mercadificação ${ }^{21}$ de formas culturais. Harvey (2010, p. 149) postula ainda que talvez a necessidade de acelerar o tempo de giro no consumo tenha provocado uma mudança de ênfase da produção de bens - como facas e garfos, que têm um tempo de vida substancial — para a produção de eventos - como espetáculos, que tem um tempo de giro quase instantâneo - , e lembramos aqui de Pine e Gilmore, com sua Economia da Experiência.

Para Harvey (2010, p. 151), interessa atentarmos para a maneira como o capitalismo está se tornando cada vez mais organizado através da dispersão, da mobilidade geográfica e das respostas flexíveis nos mercados e processos de

\footnotetext{
${ }^{20}$ Iraldo Matias (2014) aborda a ocorrência e as consequências de tal flexibilização na prática do Campo do Design. Ver: MATIAS, Iraldo Alberto Alves. Projeto e Revolução: do fetichismo à gestão, uma crítica à teoria do design. Tese de Doutorado, Instituto de Filosofia e Ciências Humanas, Universidade Estadual de Campinas. Campinas, 2014.

${ }^{21}$ Outra variante para comodificação, comoditização, mercantilização ou comercialização.
} 
trabalho e nos mercados de consumo, acompanhado por inovação tecnológica, de produto e institucional. Para o autor, a organização coesa dessa dispersão e a centralização foram alcançadas, primeiro, pela maneira como informações precisas e atualizadas são agora uma mercadoria muito valorizada - mas ele não explica como elas seriam uma mercadoria. Harvey (2010, p. 151) afirma que a renovação de interesse e a ênfase no acesso ao conhecimento científico despontaram, já que o conhecimento da última técnica, do mais novo produto, da mais recente descoberta científica, implica a possibilidade de alcançar uma importante vantagem competitiva. Com efeito, para o autor, o próprio saber se torna uma mercadoriachave a ser produzida e vendida a quem pagar mais, sob condições cada vez mais organizadas em bases competitivas - mas novamente, ele não explica como o saber seria uma mercadoria. Além disso, Harvey (2010, p. 152) postula que o controle do fluxo de informações e da propagação do gosto e da cultura populares também se converteu em arma vital na batalha competitiva.

Harvey (2010, p. 161) também afirma que o individualismo exacerbado se encaixa como condição necessária - embora não suficiente - da transição do fordismo para a acumulação flexível, pois o movimento mais flexível do capital, que acentua o novo, o fugidio, o efêmero, o fugaz e o contingente da vida moderna, tornou a ação coletiva mais difícil, e essa dificuldade constituiu, com efeito, uma expansão do controle do trabalho.

Para Harvey (p. 179-180) — vale salientarmos aqui —, a acumulação flexível ainda é uma forma de capitalismo pela sua manutenção e reprodução de propriedades básicas, como: i) a orientação do capitalismo para a expansão dos mercados; ii) o crescimento econômico dependente da exploração do trabalho em condições de assalariamento; iii) a manutenção da dinâmica tecnológica e organizacional do capitalismo. Além disso, para o autor, a acumulação flexível está longe de corresponder a uma mera mudança socioeconômica derivada unilateralmente do desenvolvimento tecnológico, pois fatores de ordem estrutural - econômicos e tecnológicos — e da ordem das práticas sociais — ação e movimentação das classes sociais existentes no mapa social e político — fornecem um quadro complexo e multifacetado acerca das mudanças econômicas verificadas com a implementação da acumulação flexível.

Por fim, Harvey (2010, p. 303-305) ainda aproxima as esferas da cultura e da economia. Para o autor, a desindustrialização e a falência da estrutura técnica 
fordista, a proliferação das tecnologias eletrônica e digital, a financeirização, a volatilidade e a indeterminação dos capitais correspondem a uma crise do fordismo baseada na estandardização e desqualificação absoluta das tarefas produtivas que, por sua vez, relacionada à separação entre concepção e execução, abriu portas à penetração de novas tecnologias. Com efeito, o desenvolvimento e aplicação massiva das novas tecnologias da informação e da comunicação permitiu um apreciável crescimento do volume de transações nos mercados financeiros de todo o mundo, e tal circulação rápida e desordenada de capitais e títulos criou, então, no cidadão comum, sentimentos de indeterminação acerca dos processos sociais e econômicos que subjazem à lógica de financeirização da economia. Em seguida, Harvey (2010, p. 303-305) discorre sobre a reprodução social e econômica, a valorização e desvalorização do capital, o consumo, a(s) moda(s) e a efemeridade, postulando que os processos de reprodução das estruturas sociais do capitalismo obedecem à necessidade contínua que o sistema econômico tem de incrementar o volume de valor econômico produzido e realizado. Assim, a elevação da produtividade e a aceleração da velocidade de rotação do capital — visíveis na obsolescência crescente de várias mercadorias - reduzem o tempo de duração dos ciclos econômicos. Logo, a necessidade de valorizar massas crescentes de capital em períodos de tempo mais curtos torna-se cada vez mais aguda, sob pena de não se realizar um volume de valor suficiente para revigorar o investimento produtivo. Deste modo, para Harvey (2010, p. 303-305), em resposta a essas dificuldades, o mundo empresarial aposta na criação de segmentos de mercado crescentemente especializados e individualizados como forma de elevar os níveis de consumo e a renovação de mercadorias. Portanto, o autor considera que a constante replicação dos desejos de consumo fomenta a efemeridade de modas, de padrões de consumo, de produtos e, consequentemente, de estilos de vida.

Das considerações de Harvey, passamos para os escritos de Ernst Mandel (1923-1995). Aqui, trataremos sobretudo de seus escritos que abordam a emergência do setor de serviços. Deste modo, o autor inicia o capítulo $A$ expansão do setor de serviços, a "sociedade de consumo" e a realização da mais-valia, do livro Capitalismo Tardio $(1982)^{22}$, ensinando-nos que o modo de produção capitalista, enquanto produção generalizada de mercadorias, implica um

\footnotetext{
${ }^{22}$ MANDEL, Ernst. O Capitalismo Tardio. São Paulo: Abril Cultural, 1982.
} 
desenvolvimento constante da divisão social do trabalho - e que essa é uma das causas da ampliação da discussão sobre mercadoria, pois novos trabalhos específicos surgem justamente a partir da divisão de práticas que antes eram desenvolvidas por um único trabalhador em todo o seu processo.

O autor afirma que a divisão cada vez maior do trabalho ocorre a partir de tendências à centralização, e esse processo de centralização tem caráter duplo: é tanto técnico quanto econômico. Assim, Mandel (1982, p. 269-270) explica que, na esfera da produção, tecnicamente, uma divisão crescente do trabalho só pode combinar-se com uma socialização crescente e objetiva por meio de uma ampliação das funções intermediárias, isto é, com a expansão de setores como comércio, transporte e serviços em geral; e economicamente, por meio de uma centralização crescente de capital como, por exemplo, sob a forma de uma integração vertical de grandes empresas, firmas multinacionais e conglomerados. Em face disto, o autor postula que a ampliação das funções intermediárias se torna indispensável, pois se, por exemplo, a produção artesanal se separa da agricultura, é preciso garantir aos camponeses a mediação dos instrumentos de trabalho e de bens de consumo que antes eles mesmos faziam à mão, e aos artesãos a mediação dos gêneros alimentícios antes produzidos por eles mesmos por meio do comércio. Logo, essa separação leva ao surgimento de um comércio independente, pois quanto mais generalizada a produção de mercadorias e quanto mais adiantada a divisão de trabalho, tanto mais essas funções intermediárias acabam sendo sistematizadas e racionalizadas, a fim de assegurar produção e venda contínuas. Com efeito, o autor afirma que a tendência à redução do tempo de giro do capital — o que é intrínseco ao modo de produção capitalista e objetivo de muitos capitalistas — só se torna realidade se o capital, tanto comercial quanto financeiro, se apossa cada vez mais das funções intermediárias.

Por conseguinte, Mandel (1982, p. 270) afirma que, na esfera da circulação no capitalismo tardio, o processo de capitalização e, consequentemente, de divisão de trabalho, também adquire nova dimensão, esta promovida sobretudo pela eletrônica e pela cibernética. Como exemplo, o autor discorre sobre os computadores, que substituem funcionários; lojas onde as pessoas por si mesmas ${ }^{23}$

\footnotetext{
${ }^{23}$ Em Janeiro de 2018, a Amazon abriu, em Seattle, a loja física chamada Amazon Go, a qual opera sem caixas e sem atendentes. Ver: www.amazon.com/b?ie $=$ UTF8\&node $=16008589011$. Acesso em 3 de Março de 2018.
} 
se servem e máquinas automáticas que tomam o lugar de vendedores e balconistas, bem como o advogado independente que dá lugar ao grande escritório de advocacia ou aos conselheiros legais de bancos, empresas e administração pública. Assim, o autor postula que a relação privada entre aquele que vende força de trabalho com qualificações específicas e aquele que gasta rendimentos privados converte-se cada vez mais em um serviço capitalista, ao mesmo tempo que se torna objetivamente socializado: o alfaiate particular é substituído pela indústria da roupa feita; a empregada doméstica pela mecanização de suas funções sob a forma de aspirador de pó, máquina de lavar roupa, de lavar pratos etc. Essa socialização objetiva ocorre sobretudo onde a infraestrutura exige o mais alto grau de racionalização em função dos altos custos fixos e das despesas de construção, como com o transporte de curta distância, o aquecimento doméstico, a iluminação, a água e o fornecimento de energia em geral, que no século XIX ainda eram puramente privados. Assim, Mandel (1982, p. 271) formula que o escravo doméstico, vivo e pessoal, foi substituído pelo escravo mecânico, inerte e socializado.

Entretanto, Mandel (1982, p. 271) afirma que essas substituições ainda contam com a necessidade de outros intermediários, menores, que ele chama de corrente secundária. Assim, por exemplo, empresas multinacionais de petróleo e gás natural, que substituíram os milhares de pequenos empreendimentos que trabalhavam com carvão e madeira, ainda necessitam de postos de gasolina e garagens para atingir os consumidores; e os serviços de água, luz e gás, centralizados e reorganizados e instalações públicas, que servem diretamente milhões de consumidores, ainda necessitam de incontáveis aparatos que fazem a mediação entre essas fontes de energia e o consumidor final, os quais demandam, por sua vez, pessoas que façam consertos, encanadores, eletricistas e vendedores. Com efeito, o autor afirma que quanto mais barata a mercadoria, isto é, quanto menor o tempo de trabalho despendido em sua produção, tanto maiores serão os custos de supervisão e reparos comparativamente aos custos de produção, e tanto mais cara, em termos relativos, a força de trabalho qualificada necessária para a realização dessa função.

Por conseguinte, Mandel (1982, p. 271-272), em um pensamento de extrema relevância crítica para o lugar comum do pensamento no Campo do Design, afirma que, longe de representar uma "sociedade pós-industrial", o capitalismo tardio constitui uma industrialização generalizada universal pela primeira vez na história. 
Conforme o autor, a mecanização, a padronização, a superespecialização e a fragmentação do trabalho, que no passado determinaram apenas o reino da produção de mercadorias na indústria propriamente dita, penetram agora todos os setores da vida social: a agricultura está se tornando gradualmente tão industrializada quanto a própria indústria, a esfera da circulação tanto quanto a esfera de produção e o lazer tanto quanto a organização do trabalho. Com efeito, Mandel (1982, p. 272) afirma que a industrialização da esfera de reprodução constitui o ápice desse processo, pois a "lucratividade" das universidades, academias de música e museus começa a ser calculada da mesma forma que das fábricas de tijolos ou de parafusos. Em suma, o autor postula que todas essas tendências correspondem à característica básica do capitalismo tardio: o fenômeno da supercapitalização, ou capitais excedentes não investidos, que acionados pela queda secular da taxa de lucro aceleram a transição para o capitalismo monopolista. Antes, enquanto o "capital" era relativamente escasso, ele concentrava-se normalmente na produção direta de mais-valor nos domínios tradicionais da produção de mercadorias; contudo, afirma Mandel (1982, p. 272), se este gradualmente se acumula em quantidades cada vez maiores, as novas massas de capital penetrarão cada vez mais áreas não produtivas, mas não criarão mais-valor, tomando lugar do trabalho privado.

Entretanto, Mandel (1982, p. 272) postula que essa enorme penetração de capital nas esferas da circulação, dos serviços e da reprodução pode, por sua vez, levar a um aumento da massa de mais-valor nos seguintes casos: i) assumindo parcialmente as funções produtivas do capital industrial propriamente dito, como é o caso no setor dos transportes, por exemplo; ii) acelerando o tempo de rotação do capital produtivo circulante, como é o caso do comércio e do serviço de crédito; iii) reduzindo os custos indiretos da produção, como se dá na infraestrutura; iv) ampliando os limites da produção de mercadorias - em outras palavras, substituindo a troca de serviços individuais por rendimentos privados pela venda de mercadorias contendo mais-valor, como no caso do aspirador de pó substituindo a empregada doméstica. Mandel (1982, p. 272) segue:

Assim, a faxineira, a cozinheira e o alfaiate particulares não produzem mais-valor; mas a produção de aspiradores de pó, sistemas de aquecimento central, eletricidade para consumo privado e refeições précozidas de produção industrial são uma forma de produção capitalista 
direta de mercadorias e mais-valor, como qualquer outro tipo de produção industrial capitalista.

Destarte, Mandel (1982, p. 273) afirma que o capital monopolista não tem motivos para hostilizar o desenvolvimento completo da industrialização e capitalização intensiva de todos os setores sociais, porque ele próprio participa desse processo - ao menos enquanto o "novo" capital desempenhar com sucesso o papel histórico de abrir novos campos de investimento e de experimentar novos produtos, de modo que a lucratividade desses novos campos seja garantida. Assim, a concentração e a centralização de capital nas áreas de alimentação e distribuição possibilitam o surgimento de grandes empresas à altura dos conglomerados de aço e de eletricidade, como Unilever e Nestlé. Essas grandes companhias tomam posse das unidades de distribuição ou tomam iniciativas de grande escala na esfera das lojas de departamentos ou dos sistemas de transporte, combinando indiscriminadamente diversas atividades para embolsar superlucros.

Assim, Mandel (1982, p. 273) conclui que se a disponibilidade de grandes quantidades de capital que não pode mais se valorizar na indústria propriamente dita — pois não são reaplicados a ela —, é um pré-requisito para a expansão do chamado setor de serviços, então uma grande diferenciação do consumo, e especialmente do consumo dos assalariados, torna-se também um pré-requisito a essas novas formas e acumulação de capital. O autor afirma que Marx previu, por assim dizer, a "sociedade de consumo", pois historicamente, a expansão do modo de produção capitalista significa uma expansão maciça dos salários monetários e uma expansão igualmente ampla do chamado "mercado interno" para bens de consumo industrializados, criados pela acumulação do próprio capital. Como, então, questiona Mandel (1982, p. 274), devemos considerar essa expansão da esfera da circulação de mercadorias de maneira a incluir os próprios assalariados, em termos de necessidades - o padrão de vida - e dos problemas de valorização e realização do capital? Dois pontos citados pelo autor nos interessam amiúde, posto que têm maior relação com o que é discutido no Campo do Design: i) diferenciação do consumo ou expansão do consumo de mercadorias, como resultado de pressão social — publicidade, conformismo; e ii) ampliação genuína das necessidades padrão de vida - do assalariado, que corresponde a uma elevação de seu nível de cultura e de civilização. 
Sobre i), Mandel (1982, p. 276) afirma que uma proporção considerável das mercadorias oriundas dessa pressão social é inútil — como o kitsch na sala de visitas - , quando não prejudicial à saúde — como os cigarros. Conforme o autor, as dificuldades de realização do mais-valor estimulam a tendência crescente dos monopólios em alterar perpetuamente a forma das mercadorias, muitas vezes de maneira absurda do ponto de vista do consumo racional, o que resulta em deterioração de qualidade - lembramos aqui tanto da obsolescência programada quanto do que "está na moda", que reduzem o período de consumo. Ainda, há que se lembrar aqui do importante capítulo escrito por Adrian Forty ${ }^{24}$, no qual, aproximando-se ao sentido dado por Mandel, ele já distinguia inovação "produtos novos", com novo valor de uso - de produtos "diferenciados" objetos classificados como "novidades" produzidas pela indústria —, oferecendo vários exemplos de sua aplicação no Campo do Design. Já sobre ii), Mandel (1982, p. 277) afirma que a ampliação genuína das necessidades é um corolário da necessária função civilizadora do capital. Toda rejeição da chamada "sociedade de consumo" deve se dar, portanto, na condenação justificada da comercialização e desumanização do consumo pelo capitalismo, naquelas iniciativas que restringem o desenvolvimento do homem, tornando-o mesquinho e unilateral, e não uma rejeição ao uso benéfico de novas mercadorias e formas de vida que enalteçam a sociedade.

Por conseguinte, um ponto importante para o nosso estudo é a breve diferenciação que Mandel (1982, p. 278) faz do que ele chama de "padrão racional de desenvolvimento do consumo" ou "distinção entre atividade criativo-produtiva e consumo passivo de bens": não se "consome" um piano, um livro científico, uma amizade ou uma paisagem da mesma forma que um sorvete ou uma camisa devemos manter isso em mente ao pensarmos o Campo do Design mais à frente.

Mandel (1982, p. 278-279) prossegue, afirmando que quanto mais satisfeito o consumo efetivo de mercadorias, tanto mais irracional e indiferente ao homem se torna a sua expansão quantitativa, degenerando em pura extravagância, tédio e aversão à vida. $\mathrm{O}$ autor afirma que, nesse contexto, faz-se necessário apreender a dupla natureza do desenvolvimento do consumo material enquanto consumo de mercadorias produzidas em massa, e apoia-se na afirmação de Marx de que o

\footnotetext{
${ }^{24}$ Ver referência nota 5 do Capítulo 2 - Da experiência.
} 
capitalismo cria a produção em larga escala, determina simultaneamente o caráter unilateral e massificado do produto, o qual impõe um caráter social estreitamente ligado ao contexto social, enquanto sua relação imediata com o valor de uso que supostamente satisfaz a necessidade do produtor parece algo contingente, indiferente e secundário. Mandel (1982, p. 278-279) considera que essa dimensão do consumo parece ter sido negligenciada por aqueles que nada veem de problemático na comercialização universal de "bens" e "serviços" tais como "bens culturais" e serviços de "civilização", esquecendo-se de que a produção desses bens está subordinada à motivação do lucro do comércio capitalista: a "massa de compradores" não pode ser soberana, se a característica predominante da "nova publicidade" é que esses "consumidores soberanos" têm primeiro de ser persuadidos de suas novas necessidades.

Entretanto, Mandel (1982, p. 279) também afirma que, apesar da expansão considerável do consumo em países altamente industrializados, o que o modo de produção capitalista não pode fazer é aumentar esse consumo à mesma taxa do aumento da produtividade do trabalho, pois a obrigação de valorizar e de acumular capital - em outras palavras, a concorrência e a propriedade privada dos meios de produção - impossibilita tal coisa. Assim, o autor afirma que se a longo prazo o consumo se desenvolve mais lentamente em termos de valor do que a produtividade, então será cada vez mais difícil realizar o mais-valor contido nos bens de consumo ou utilizar plenamente a capacidade social de produção de bens de consumo. É por isso que se desenvolvem, conforme Mandel (1982, p. 280), a publicidade e a pesquisa de mercado, por um lado, e o crédito ao consumidor, por outro, com a função de extravasar esses limites. Já sobre a questão do crédito, Mandel (1982, p. 281) aponta que a grande expansão do crédito ao consumidor no capitalismo tardio proporciona evidências das dificuldades crescentes na realização do mais-valor, pois isso prova que, apesar da acelerada inovação tecnológica, dos investimentos maiores e do armamento permanente, o capitalismo tardio não é mais capaz do que o capitalismo juvenil ou o capitalismo monopolista clássico de resolver uma das contradições fundamentais do modo de produção capitalista: a contradição entre a tendência ao desenvolvimento ilimitado das forças produtivas e a tendência à limitação da demanda e do consumo dos "consumidores finais" estes cada vez mais constituídos por trabalhadores assalariados. 
Assim, Mandel (1982, p. 281-282) resume seu argumento ao postular que uma expansão do setor de serviços no capitalismo tardio consiste de: i) tendência a uma expansão geral das funções intermediárias; ii) tendência a uma vasta expansão tanto dos custos de venda - publicidade, marketing, embalagens caras e outras despesas improdutivas - quanto do crédito ao consumidor, sendo a maior parte dessa expansão do setor de serviços determinada socialmente, e não tecnicamente; iii) possibilidades de crescimento das necessidades culturais e civilizadoras da população trabalhadora - educação, saúde, lazer - como algo distinto do mero consumo de mercadorias; iv) a expansão da produção de mercadorias que não é absolutamente parte do chamado "setor de serviços", mas é resultado da centralização crescente de certas formas de produção que antes eram basicamente privadas: eletricidade, gás, água, refeições prontas industrializadas e aparelhos eletrodomésticos são bens materiais e sua produção é produção de mercadorias no seu verdadeiro sentido e não, de forma alguma, venda de serviços; v) o crescimento do número de trabalhadores assalariados empregados de forma improdutiva, em virtude da penetração maciça de capital na esfera da circulação e dos serviços.

Assim, Mandel (1982, p. 282) discorre que a expansão do setor de serviços capitalistas resume todas as principais contradições do modo de produção capitalista: reflete a enorme expansão das forças produtivas sociotécnicas e científicas e o crescimento das necessidades culturais e civilizadoras dos produtores, exatamente como reflete a forma antagônica como essa expansão se realiza sob o capitalismo: pois ela se faz acompanhar de uma supercapitalização crescente (dificuldades de valorização do capital), de dificuldades crescentes de realização, de desperdício crescente de valores materiais e de alienação e deformação crescentes dos trabalhadores em sua atividade produtiva e em seu âmbito de consumo.

Em seguida, Mandel (1982, p. 282) busca esclarecer a querela entre capital produtivo e improdutivo no setor de serviços. Ele questiona: o capital investido no setor de serviços é ou não produtivo $?^{25} \mathrm{O}$ trabalho executado pelos trabalhadores

\footnotetext{
${ }^{25}$ Mandel (1982, p. 412) define capital produtivo como parte do capital social investida em setores em que se produz mais-valor diretamente. O capital improdutivo, assim como o capital comercial ou bancário, pode adquirir parte do mais-valor social total porque isso ajuda a reduzir o tempo de rotação do capital, ou a ampliar o alcance da produção por meio do crédito para além dos limites operantes do próprio capital produtivo e, assim, contribui indiretamente para o aumento do maisvalor.
} 
assalariados nesse setor é produtivo ou improdutivo ${ }^{26}$ Segundo o autor, a fórmula "no capitalismo, trabalho produtivo é trabalho que cria mais-valor" é inadequada para essa definição, pois não responde à questão dos limites do trabalho produtivo, apenas a apresenta de outra forma. Deste modo, Mandel (1982, p. 283) postula que não há razão plausível para que a troca de serviços por rendimentos, à medida em que não leva à produção de mercadorias, deva tornar-se subitamente produtiva apenas porque é organizada como atividade capitalista e executada por trabalho assalariado. Ele recorre a Marx, que, em Theories of Surplus Value (1972) ${ }^{27}$, distingue o trânsito de pessoas - que envolve a troca improdutiva de um serviço pessoal por rendimentos — do trânsito de mercadorias, que aumenta seu valor de troca e é, portanto, produtivo. Para Marx (1972, p. 412-413), a quantidade de um produto não aumenta com o transporte e o valor de uso das coisas só se materializa em seu consumo. Entretanto, seu consumo pode requerer uma mudança de localização, o que pode exigir um processo adicional de produção na indústria do transporte. Com efeito, o capital produtivo investido nessa indústria transfere valor para os produtos transportados, em parte acrescentando valor por meio do trabalho realizado no transporte. Ampliando essa definição de Marx, podemos concluir que o verdadeiro capital de serviços — à medida que não seja erroneamente confundido com o capital que produz mercadorias - não é capital produtivo.

Por fim, Mandel (1982, p. 285) conclui que uma sociedade constituída apenas de serviços, na qual o trabalho seja apenas assalariado improdutivo - que já não produz mercadorias —, acabaria por confrontar-se com o problema de que os trabalhadores assalariados não poderiam usar seus salários apenas para comprar "serviços capitalistas", pois primeiro teriam de comer, beber, vestir, conseguir moradia e garantir fontes de energia, antes de poder ir ao médico, consertar os sapatos ou fazer uma viagem de férias. Logo, o capital investido nas "empresas de serviços" dificilmente conseguiria atingir a "valorização". Se os bens que fossem inteiramente produzidos por processos automáticos já não fossem vendidos, mas

\footnotetext{
${ }^{26}$ Mandel (1982, p. 415) define trabalho produtivo como aquele que, numa sociedade capitalista, é apenas o trabalho que produz mais-valor diretamente. Já trabalho improdutivo corresponde a todas as formas de trabalho assalariado que não aumentam o volume de mais-valor social, mas que ajudam grupos específicos de capitalistas a se apropriarem de parte desse mais-valor, ou que aumentam indiretamente o mais-valor - por exemplo: trabalho assalariado no comércio, nos bancos ou na administração.
}

${ }^{27}$ MARX, Karl. Theories of Surplus Value, v.1. Londres, 1972. 
distribuídos gratuitamente, então é difícil imaginar um motivo que levasse as massas, que dessa maneira teriam assegurado o seu padrão de vida, a alugar sua força de trabalho para as "empresas de serviços". Conforme o autor, em outras palavras, esse cenário não teria mais nada a ver com o capitalismo.

Deste modo, vimos com Mandel — um autor com escritos mais centrados na questão sobretudo econômica, e não artística ou cultural — que nem tudo o que gera lucro pode ser considerado uma mercadoria. O exemplo do setor de serviços ilustra bem esta distinção, a qual é pouco referida, ou não é considerada, quando nos deparamos com estudos sobre a "comodificação". Outro ponto importante do texto de Mandel - e aqui podemos incluir também Harvey — é que esses autores tomam conta da esfera da produção, e não apenas da circulação, aspecto que ajuda a clarificar os nossos entendimentos, tendo em vista que antes de entrar em circulação, algo tem que ser produzido. Assim, à luz dos escritos de Harvey e Mandel, podemos retomar nosso questionamento: pode a experiência ser uma mercadoria? Que tipo de capital ela gera e que tipo de trabalho a "produz", por exemplo?

\subsection{3.}

\section{A mercadoria "pós-moderna"}

Fredric Jameson segue algumas das diretrizes de Mandel do capitalismo tardio, mas se concentra em uma discussão voltada à cultura, ecoando a indústria cultural de Adorno e Horkheimer. Na publicação de que trataremos aqui, Pós-Modernismo: $a$ lógica cultural do capitalismo tardio ${ }^{28}$, escrita em 1991, o autor vê a cultura totalmente imbricada com a economia no capitalismo tardio, e seu argumento se desenvolve na tentativa de provar isto.

Jameson (1997, p. 14) afirma que o que aconteceu com a cultura pode muito bem ser uma das pistas mais importantes para se detectar um eventual "novo" regime que poderíamos chamar de cultura pós-moderna: uma dilatação imensa de sua esfera (a esfera da mercadoria), uma aculturação historicamente original do Real e um salto quântico no que Benjamin denominava a "estetização" da realidade.

\footnotetext{
${ }^{28}$ JAMESON, Fredric. Pós-modernismo: a lógica cultural do capitalismo tardio. São Paulo: Ática, 2007.
} 
Assim, conforme Jameson (1997, p. 14-15), nesse período de uma eventual cultura pós-moderna, a própria "cultura" se tornou um produto, um produto exatamente igual a qualquer um dos itens que encontramos no mercado. $\mathrm{O}$ autor considera que enquanto o modernismo era, ainda que minimamente e de forma tendencial, uma crítica à mercadoria e um esforço de forçá-la a autotranscender, no eventual regime de uma cultura do pós-modernismo, o tema aparece como o consumo da própria produção de mercadorias como processo [grifo nosso] - e atentamos aqui para o uso do termo processo, tão em voga no Campo do Design com projetos de Design Thinking, que consideram a atividade desta prática profissional como um processo.

Para Jameson (1997, p. 16-18), nos passos de Mandel, o pós-modernismo não é a dominante cultural de uma ordem social totalmente nova - como pensam aqueles que postulam a supracitada sociedade (pós-)industrial, em uma óbvia missão ideológica de demonstrar que a nova formação social em questão não mais obedece às "modernas" leis do capitalismo clássico, a saber, o primado da produção industrial e a onipresença da luta de classes -, mas sim reflexo e aspecto concomitante de mais uma modificação sistêmica do próprio capitalismo. Entretanto, ele afirma que a adoção do novo termo parece sugerir algo diferente, sobretudo por desviar a atenção dos fatores econômicos imbrincados. Com efeito, o autor postula que a ideia de catalogar mais uma vez e transcodificar termos tem seu próprio aspecto significativo, pois essa é uma função ativa, ética e com consequências políticas. Logo, Jameson (1997, p. 18) afirma que se "pósmodernismo" corresponde ao que Raymond Williams queria dizer com "estrutura de sentimento"29, sua categoria cultural fundamental, o pós-modernismo só foi capaz de atingir esse status por força de uma profunda transformação coletiva, um retrabalho e uma reescritura de um sistema mais antigo.

Jameson (1997, p. 18) afirma que mesmo com essa nova perspectiva, a tarefa ideológica fundamental do novo conceito deve continuar a ser a de coordenar as novas formas de prática e de hábitos sociais e mentais - estrutura de sentimento - e as novas formas de organização e de produção econômica que vêm com a modificação do capitalismo e com a nova divisão global do trabalho, em que a interrelação do cultural com o econômico não é uma rua de mão única, mas sim uma contínua interação recíproca, um circuito de realimentação.

\footnotetext{
${ }^{29}$ Ver referência na nota 114 do Capítulo 2 - Da experiência.
} 
O autor também segue os passos de Mandel - para quem estaríamos no estágio do capitalismo mais puro do que qualquer dos momentos que o precederam - ao utilizar o termo capitalismo tardio, e aponta que "tardio" marca justamente uma continuidade em relação ao que o precedeu e não uma quebra, ruptura ou mutação. Além da nova divisão internacional do trabalho, Jameson (1997, p. 2223) aponta que as novas empresas transnacionais, a nova dinâmica vertiginosa de transações bancárias internacionais e das bolsas de valores, as novas formas de inter-relacionamento das mídias, computadores e automação e a fuga da produção para áreas desenvolvidas de países em desenvolvimento constituem características deste novo momento. Culturalmente, o autor afirma que as características do capitalismo tardio nasceram junto das precondições das grandes transformações sociais e psicológicas dos anos 1960, que varreram do mapa muitas tradições: “o habitus psíquico de uma nova era exige uma quebra radical, fortalecida por uma ruptura de gerações.” (JAMESON, 1997, p. 23) Assim, Jameson (1997, p. 25) vê uma ligação totalmente imbricada entre cultura e economia, afirmando que ambos se fundem e significam a mesma coisa, eclipsando a distinção entre base e superestrutura - o que ele julga parecer ser uma característica significativa de um eventual regime cultural pós-moderno, sugerindo que a base, no capitalismo tardio, gera sua superestrutura através de um novo tipo de dinâmica. E complementa: "e isso pode bem ser o que preocupa os que não aderiram ao termo; este parece nos obrigar, de antemão, a tratar os fenômenos culturais no mínimo em termos de business, se não nos termos da economia política".

Após esta contextualização do pensamento de Jameson, trataremos de dois capítulos do livro que aqui empregamos, posto que estes apresentam maior relação com a questão da mercadoria que investigamos: A lógica cultural do capitalismo tardio e $O$ pós-modernismo e o mercado. No primeiro capítulo, A lógica cultural do capitalismo tardio, Jameson (1997, p. 27-79) trata do que postula como estética de mapeamento cognitivo. Antes, ele discorre sobre as condições do capitalismo tardio que o levaram a propor esse modo de visão. Vamos a eles agora.

Jameson (1997, p. 28-29) afirma que qualquer ponto de vista a respeito do pós-modernismo na cultura é, ao mesmo tempo, necessariamente, uma posição política, implícita ou explícita, com respeito à natureza do capitalismo em nossos dias. Neste sentido, o autor postula que pensar que a produção estética hoje está integrada à produção de mercadorias em geral corresponde a uma identificação da 
urgência desvairada da economia em produzir novas séries de produtos que cada vez mais pareçam "novidades", com um ritmo cada vez maior, atribuindo uma posição e uma função estrutural cada vez mais essenciais à inovação estética, em posição diferente da que se tinha entre arte e economia durante o modernismo. Para exemplificar essa proximidade econômica, Jameson (1997, p. 30) discorre sobre a arquitetura, que, para o autor, tem, na forma de encomendas e no valor de terrenos, uma relação virtualmente imediata. E continua: "não é de surpreender, então, que tenha havido um extraordinário florescimento da nova arquitetura pós-moderna apoiado no patrocínio de empresas multinacionais, cuja expansão e desenvolvimento são estritamente contemporâneos aos da arquitetura." (JAMESON, 1997, p. 30) Talvez este não seja um bom exemplo para a nossa reflexão sobre mercadoria, pois a Arquitetura sempre teve o viés econômico muito forte, diferente das produções das Artes Visuais/Belas Artes. Mais à frente no texto, tangenciando melhor a nossa inquietação, Jameson (1997, p. 35-38) questiona se as obras de Warhol seriam centradas em torno da mercantilização. Caso não o sejam, ele pergunta: por que podemos pensar isso hoje? E estrelas, como Marilyn Monroe, que se tornam mercadorias e se transformam em sua própria imagem?

$\mathrm{Na}$ linha de pensamento da Arte e da Cultura como mercadorias, Jameson (1997, p. 42-43) afirma que esta discussão recai ainda no tema da "morte" do próprio sujeito e sua ênfase correlata, seja como um novo ideal moral, seja como descrição empírica, no descentramento do sujeito, ou psique, antes centrado. Mas isso também implica o fim de muitas outras coisas - o fim, por exemplo, do estilo (temos ecos da Escola de Frankfurt aqui), no sentido do único e do pessoal, o fim da pincelada individual distinta - como simbolizado pela primazia emergente da reprodução mecânica - e sentimentos autossustentados e impessoais.

Assim, Jameson (1997, p. 60-61) afirma que o outro da nossa sociedade não é mais a natureza, como era nas sociedades pré-capitalistas, mas sim a tecnologia - novamente, podemos ouvir ecos da Escola de Frankfurt. Ele afirma: "a tecnologia pode servir como uma forma abreviada para designar o poder do propriamente humano e, portanto, antinatural presente no trabalho humano descartado acumulado em nossas máquinas — um poder alienado, que se volta contra nós em formas irreconhecíveis e parece constituir-se no horizonte distópico massivo de nossas práxis, coletiva e individual." Entretanto, o autor também 
pondera que não devemos ver a tecnologia como uma instância determinante em si, mas sim como resultado do desenvolvimento do capital.

Jameson (1997, p. 63) afirma que a tecnologia de nosso próprio momento histórico tem capacidade de representação da reprodução, e não da produção, como se dava antes com elementos industriais. Ele cita o exemplo do computador, cuja forma exterior não tem nenhum apelo visual ou emblemático — hoje isso já não seria válido, tendo em vista o apelo estético das mercadorias da Apple, por exemplo —, ou então pelos invólucros das várias mídias, que pouco articulam em suas faces achatadas. Assim, o autor considera que a materialização estética de tais processos acaba frequentemente caindo na forma mais cômoda da mera representação temática do conteúdo, em narrativas que são sobre processos de reprodução. Essas representações imperfeitas correspondem a uma imensa rede computadorizada de comunicações que são, em si mesmas, apenas uma figuração distorcida de algo ainda mais profundo, a saber, todo o sistema mundial do capitalismo multinacional de nossos dias. Com efeito, para Jameson (1997, p. 63-63), a tecnologia da sociedade contemporânea é hipnótica e fascinante, não tanto em si mesma, mas porque nos oferece uma forma de representar nosso entendimento de uma rede de poder e de controle que é ainda mais difícil de ser compreendida por nossas mentes e por nossa imaginação, a saber, toda a nova rede global descentrada do capitalismo tardio.

Jameson (1997, p. 72) atenta para o fato de que a concepção de pósmodernismo esboçada é uma concepção histórica e não meramente estilística. É preciso insistir na diferença radical entre uma visão do pós-modernismo como um estilo entre muitos outros disponíveis e uma visão que procura apreendê-lo como a dominante cultural da lógica do capitalismo tardio, uma tentativa genuinamente dialética de se pensar o tempo presente na história. Por conseguinte, Jameson (1997, p. 74) questiona a semiautonomia da esfera cultural, perguntando-se se essa não foi destruída pela lógica do capitalismo tardio, pois o argumento de que a cultura hoje não é mais dotada da autonomia relativa que teve em momentos anteriores do capitalismo não implica, necessariamente, afirmar o seu desaparecimento ou extinção. Ao contrário, o autor afirma que o passo seguinte é afirmar que a dissolução da esfera autônoma da cultura deve antes ser pensada em termos de uma explosão: uma prodigiosa expansão da cultura por todo o domínio social, até o ponto em que tudo em nossa vida social pode ser considerado como cultural - do 
valor econômico e do poder do Estado às práticas e à própria vida estruturada da psique. Entretanto, para Jameson (1997, p. 75), essas são também tentativas de nos distrair e nos desviar dessa realidade, ou de disfarçar suas contradições e resolvêlas na aparência de várias mistificações formais.

Assim, Jameson (1997, p. 76) afirma que uma concepção de espaço que tome conta dessa realidade deve sugerir um modelo de cultura política apropriado, considerando os problemas do espaço como sua questão organizativa fundamental. Para isso, ele define essa nova - e hipotética - forma cultural como uma estética de mapeamento cognitivo. Segundo o autor, esta estética de mapeamento cognitivo - uma cultura política e pedagógica que busca dotar o sujeito individual de um sentido mais aguçado de seu lugar no sistema global - terá que levar em conta uma dialética representacional extremamente complexa. Para o autor, a nova arte política — se ela for de fato possível — terá que se ater à verdade do regime cultural do pós-modernismo, isto é, a seu objeto fundamental — o espaço mundial do capital multinacional -, ao mesmo tempo em que terá que realizar a façanha de chegar a uma nova modalidade, que ainda não somos capazes de imaginar, na qual possamos entender nosso posicionamento como sujeitos individuais e coletivos e recuperar nossa capacidade de agir e lutar, que está hoje neutralizada pela nossa confusão espacial e social.

Por conseguinte, Jameson (1997, p. 268-269) inicia o capítulo $O$ pósmodernismo e o mercado discorrendo sobre as tentativas de separar a ideologia da realidade: "a ideologia do mercado não é, infelizmente, um luxo suplementar de ideias ou de representação, um enfeite que pode ser removido do problema econômico." Conforme o autor, ela é gerada pela coisa em si, como sua imagem final objetivamente necessária: de algum modo, as suas dimensões têm que ser registradas juntas, em sua identidade assim como em sua diferença. Ele afirma que elas são semiautônomas, o que significa que elas não são realmente autônomas e independentes uma da outra, mas tampouco são idênticas, e que o conceito de Marx de ideologia sempre pretendeu respeitar, encenar e dobrar o paradoxo da mera semiautonomia do conceito ideológico. Assim, Jameson (1997, p. 270) postula que a ideologia é uma característica necessária da própria estrutura da realidade.

Jameson (1997, p. 273) afirma que no slogan do mercado não há nenhuma verdade: para começar, no domínio dos oligopólios e das multinacionais, não existe hoje nenhum mercado livre. Para o autor, na acepção geral, mercado como conceito 
raramente tem alguma coisa a ver com escolhas e com liberdade, uma vez que todas são já predeterminadas, quer estejamos falando de novos modelos de carro, de brinquedos ou de programas de televisão: selecionamos entre alguns, mas não podemos dizer que influímos na escolha real de nenhum deles. Contudo, o autor também afirma que se presume que o slogan do mercado foi ideado justamente para uma mudança decisiva e um deslocamento da esfera da produção para a da distribuição e do consumo. Com efeito, Jameson (1997, p. 274) considera que as razões do sucesso da ideologia do mercado não podem assim ser procuradas no próprio mercado: devemos procurá-la justamente em instâncias que deneguem o mercado.

Jameson (1997, p. 274-279) então postula que no capitalismo tardio podemos considerar que o consumo é explicitamente descrito como a produção de uma mercadoria, ou de um bem específico; em outras palavras, um valor de uso que pode ser qualquer coisa, de gratificação sexual a um local conveniente para determinada atividade. Assim, o mercado seria como estrutura "totalizante", capaz de nos oferecer um modelo da totalidade social.

Por conseguinte, Jameson (1997, p. 281-282) passa a discorrer sobre o papel da mídia no mercado. Apesar de ela nos apresentar uma livre seleção de programas — o consumidor, entretanto, não escolhe nem o conteúdo dos programas nem seu agrupamento - , essa seleção é rebatizada de "livre escolha". O autor considera que no processo do desaparecimento gradual do espaço físico do mercado e da identificação gradual da mercadoria com sua imagem, dá-se uma outra simbiose, mais íntima, entre o mercado e a mídia. Nessa simbiose, as fronteiras ficam submersas e a indiferenciação de níveis gradualmente toma o lugar da separação anterior entre a coisa e seu conceito - ou, na verdade, economia e cultura, base e superestrutura, afirma o autor. Com efeito, Jameson (1997, p. 282) considera que, para começar, os produtos à venda no mercado transformam-se no próprio conteúdo das imagens da mídia, de tal forma que, em certo sentido, o mesmo referente parece se manter nos dois domínios. Para o autor, isso é algo bem diferente de uma situação mais primitiva, na qual a uma série de signos de informação — notícias, folhetins, artigos - era adicionado a um outro elemento, que tentava aliciar consumidores para um produto comercial que não tinha nada a ver com esses signos. Hoje, para Jameson (1997, p. 282), os produtos estão difusos no tempo e no espaço dos 
segmentos de entertainment como parte do conteúdo, de tal forma que em alguns casos, seus limites não ficam claros.

Para Jameson (1997, p. 282-283), essa interpenetração através do conteúdo é então intensificada de forma um tanto diferente pela própria natureza dos produtos: para o autor, a impressão que se tem é que os produtos se organizam em uma espécie de hierarquia cujo ponto mais alto é precisamente a tecnologia de reprodução. Logo, temos que dar conta também de outro tipo de consumo: o consumo do próprio processo de consumo, muito além do seu conteúdo e dos produtos comerciais mais imediatos. Conforme o autor, é preciso falar de uma espécie de bônus tecnológico de prazer, pois muito da euforia do pós-modernismo deriva dessa apologia do próprio processo da informatização tecnológica.

Conforme Jameson (1997, p. 283), é nesse ponto que o processo se reverte: não são mais os produtos comerciais do mercado que se tornam imagens na propaganda, mas sim os próprios processos de diversão e de narrativas que são, por sua vez, reificados e transformados em mercadorias. Assim, o autor enxerga o aparecimento de um novo domínio da realidade das imagens, o qual é a um só tempo ficcional — narrativo - e factual. Por conseguinte, para Jameson (1997, p. 283), hoje a cultura tem um tal impacto na realidade que torna problemática qualquer forma de realidade não-cultural ou extracultural.

Por fim, Jameson (1997, p. 284) afirma que no capitalismo os conteúdos da própria mídia se transformam em mercadorias, que são então lançadas em uma versão mais ampliada do mercado a que se incorporam de tal forma que as duas coisas se tornam impossíveis de distinguir. Logo, para o autor, a mídia - como aquilo que o mercado fantasiava - volta agora ao mercado e, ao se tornar parte dele, sela e certifica a identificação antes metafórica ou analógica como sendo uma realidade "literal".

Vimos que Jameson considera o consumo, ou seja, os fenômenos da esfera da circulação, como mercadoria, evidenciando o papel da publicidade nas configurações artísticas e culturais do capitalismo tardio. O autor traz muitos pontos semelhantes aos tratados pela Escola de Frankfurt em 1944, como justamente o papel da propaganda, mas também da tecnologia — deste modo, pudemos enxergar aqui algumas das assombrações que sugerimos existir ao início do capítulo. Com efeito, de acordo com Jameson, perguntamo-nos: podemos considerar a experiência como uma mercadoria? 


\section{2.4.}

\section{Mercadorias ou produtos? A querela no Campo do Design}

Quanto à discussão sobre mercadoria no Campo do Design, Iraldo Matias é quem traz uma contribuição. Com seu trabalho intitulado Projeto e Revolução: do fetichismo à gestão, uma crítica à teoria do design ${ }^{30}$, o autor se concentra, dentre outros assuntos, na discussão acerca do emprego do termo produto em detrimento de mercadoria no Campo do Design, uma escolha semântica que ele julga carregada de mistificação e ideologia. Assim, qual a diferença entre produto e mercadoria? E quais as consequências do emprego do primeiro em detrimento do segundo no Campo do Design?

Matias (2014, p. 173) inicia seu pensamento citando Löbach (2001, p. 14) ${ }^{31}$, para quem o processo de Design consiste da "satisfação de uma necessidade na forma de um produto industrial.” Em contrapartida, o autor recorre então à Marx $(1983 \text {, p. } 151)^{32}$, para quem um produto deveria ter como fundamento ontológico um valor de uso, uma matéria natural adaptada às necessidades humanas mediante transformação da forma, sendo o valor de uso de uma coisa a sua utilidade. Entretanto, Matias (2014, p. 173) salienta que para Marx o valor de uso é apenas um aspecto da mercadoria, enquanto que para Löbach ele consiste da totalidade do produto. Ainda para Marx (1983, p. 151), os produtos não consistem de apenas objetos de consumo, mas são, como já vimos, "não só resultados, mas também condições do processo de trabalho." Com efeito, o autor postula que o valor de uso compreende o aspecto qualitativo das mercadorias e só se realiza com sua utilização, seja na produção ou no consumo particular. Matias (2014, p. 173) complementa afirmando que, para Marx (1983), uma coisa pode ser valor de uso sem decorrer do trabalho — o ar, a água, por exemplo — , bem como uma coisa pode ser útil e produto do trabalho humano e não ser mercadoria - como a produção de subsistência. Assim, existe uma relação direta entre o valor de uso da

\footnotetext{
${ }^{30}$ Ver referência na nota 20.

${ }^{31}$ LÖBACH, Bernd. Design Industrial: Bases para a configuração dos produtos industriais. São Paulo: Edgard Blücher, 2001.

${ }^{32}$ Matias faz uso da edição da Abril Cultural de 1983 d'O Capital: MARX, Karl. O Capital, Livro I, Vol.1. São Paulo: Abril Cultural, 1983.
} 
mercadoria e o aspecto qualitativo do trabalho humano, ou trabalho útil, envolvido em sua produção.

Entretanto, Matias (2014, p. 174) afirma que no Campo do Design há uma relação imprecisa de exterioridade entre o trabalho vivo e os produtos industriais, posto que geralmente se considera somente a atividade projetual como configuradora de produtos, relegando o trabalho de execução e materialização das mercadorias a uma atividade mecânica inferior, desprovida da criatividade presente na atividade projetual. Assim, o emprego do termo produto não daria conta da posição de mercadoria que ele tem no Campo, dissimulando o caráter econômico e de valor imbrincados ao trabalho humano por trás de sua produção.

Em um segundo momento, Matias (2014, p. 174), discorre sobre o equivocado emprego dos termos valor de troca e valor no Campo do Design, e suas consequências para um claro entendimento do Campo. O autor afirma que o duplo caráter da mercadoria raramente é abordado no Campo do Design ${ }^{33}$, e que considerar apenas o valor de troca, e não o valor, evidencia a posição ideológica de ignorar o papel determinante das relações sociais de produção, além de transferir o foco da análise para a esfera da circulação ou simplesmente para o mercado. Matias (2014, p. 175) cita Iida (1998, p.49, itálico no original) $)^{34}$, cuja afirmação se repete no Campo: "Design é uma atividade que adiciona valor ao produto [...] pois aumenta-se o valor melhorando itens como funcionalidade, confiabilidade, durabilidade, adaptação ergonômica, estética e todas as demais características consideradas desejáveis pelos consumidores." Como contraponto, Matias (2014, p. 175) traz Marx (1983, p. 46), o qual afirma que o valor das mercadorias diz respeito à sua dimensão puramente quantitativa, pois é precisamente a abstração do valor de uso que caracteriza a relação de trocas entre mercadorias. Este valor só pode ser medido a partir da quantidade de trabalho cristalizado - trabalho abstrato, conforme já vimos anteriormente. Com efeito, Matias (2014, p. 175) sumariza que na medida em que a equivalência entre as mercadorias, no processo de troca, se define por quantidades de trabalho, tem-se a abstração de seus aspectos qualitativos.

\footnotetext{
${ }^{33}$ Alberto Cipiniuk trata das noções de valor de uso e valor hoje no Campo do Design. Ver: CIPINIUK, Alberto. O Campo do Design e a crise do monopólio da crença. São Paulo: Blucher, 2017.

${ }^{34}$ IIDA, Itiro. Ergonomia: Projeto e Produção. São Paulo: Edgard Blücher, 2005.
} 
Assim, não podemos considerar que o Design adiciona valor ao produto, pois o valor de uma mercadoria é definido a partir do tempo de trabalho socialmente necessário contido nela.

Em seguida, Matias (2014, p. 177) afirma que no Campo do Design a questão do fetiche da mercadoria fica evidente, uma vez que os "produtos" não são definidos como mercadoria, seu entendimento enquanto resultado das relações sociais de produção fica obscurecido, e ele é reduzido a meras relações de "mercado" [grifo do autor]. Com efeito, o autor postula que essa fantasmagoria que circunda a produção e a circulação de mercadorias, ao ser transposta para o Campo do Design, não permite a apreensão das características sociais do trabalho como características objetivas dos próprios produtos do trabalho, aspecto que desemboca em um entendimento, segundo os termos de Marx (1983, p. 100), da personificação da coisa e da reificação das pessoas.

Matias (2014,p. 177-178) afirma que o conceito de fetichismo sofreu novas apropriações e interpretações ao longo do século XX, sobretudo com o exponencial crescimento da propaganda, do marketing, e uma consequente ênfase na esfera da circulação/consumo - a supracitada "sociedade do consumo" —, em detrimento da esfera da produção. O autor cita a Escola de Frankfurt e Wolfgang Fritz Haug, dentre outros autores que se debruçaram nesta tarefa. Tendo em vista que já discorremos sobre a Escola de Frankfurt, vamos agora discorrer brevemente sobre o pensamento de Haug.

Haug, em 1971, na primeira edição do livro Crítica da estética da mercadoria ${ }^{35}$, postula que a estética de uma mercadoria passa a ser uma mercadoria em si. O valor de uso é transformado em simples imagem, aparência desprovida de conteúdo real, que não passa de mera "promessa de valor de uso". Assim, Matias (2014, p. 179) postula que, conforme Haug (1997, p. 15), a estética da mercadoria designa "um complexo funcionalmente determinado pelo valor de troca e oriundo da forma final dada à mercadoria, de manifestações concretas e das relações sensuais entre sujeito e objeto por elas condicionadas." O foco do autor é o sensualismo da mercadoria, sua capacidade de sedução a partir de um ajustamento estético de sua forma, a fim de despertar os "desejos do consumidor" e concretizar o processo de troca. Assim, Matias (2014, p. 180) afirma que o Design, a

\footnotetext{
${ }^{35}$ HAUG, Wolfgang Fritz. Crítica da estética da mercadoria. São Paulo: UNESP, 1997.
} 
propaganda, o marketing e o branding são todos meros instrumentos de sedução e de convencimento que não têm outra finalidade, senão a "venda". Para colimar este argumento, ele cita uma resposta dada por Haug (1997, p. 194) a uma pesquisa do Centro Internacional de Design, no qual o autor responde à pergunta "Que funções cabem ao Design?":

No ambiente capitalista cabe ao Design uma função que se pode comparar à função da Cruz Vermelha durante a guerra. Ele cuida de algumas poucas - jamais as piores - feridas causadas pelo capitalismo. Ele trata do rosto e, embelezando alguns pontos e mantendo o moral elevado, prolonga o capitalismo, tal como a Cruz Vermelha fez com a guerra. O Design mantém assim a organização geral, por meio de uma configuração espacial. Ele é responsável pelas questões da apresentação em geral, e da apresentação do meio ambiente. Para tais funções, o fascismo alemão instituiu toda uma série de departamentos públicos, por exemplo, o Departamento para a Beleza do Trabalho. Desse modo, o Design tem funções políticas. Ao apresentar as mercadorias, ele promove a sua vendabilidade assumindo assim diretamente uma função de valorização do capital.

Matias (2014, p. 180) cita ainda Selle ${ }^{36}$, para quem não se pode provar que os produtos "bem projetados" correspondam à presença sensível de seu valor de uso, nem que reconheçam a autêntica necessidade social que venham a permitir um uso e uma autorrealização livres.

Por fim, Matias (2014, p. 183) discorre que, na medida em que o "fenômeno da mercadoria" não pode ser dissociado do "fenômeno do mais-valor", o imperativo do projetar se coloca, nestes termos, acima da problemática da exploração. Logo, aceitar a mercadoria significa aceitar o mais-valor, constituindo-se como momentos indissociáveis. Matias (2014, p. 186) ainda afirma que para o Design, há duas variáveis para a tomada de posição que dificilmente coincidem: a importância do produto para o "usuário" e sua importância para o êxito financeiro da empresa. O autor afirma que ao preconizar sua "ligação espiritual" com o valor de uso - a importância do produto para o "usuário" — o designer não apreende, em sua totalidade, os aspectos da subordinação deste ao valor de troca. Em sua querela com Löbach, Matias (2014, p. 187) demonstra quando aquele, de fato, parece reconhecer

\footnotetext{
${ }^{36}$ SELLE, Gert. Ideología y utopía del diseño: contribución a la teoría del diseño industrial. Barcelona: Gustavo Gili, 1973.
} 
a superioridade do mercado frente à atividade projetual. Conforme Löbach: "ao objetivo principal do aumento do lucro se subordinam todos os demais, inclusive a configuração de produtos fabricados na empresa" e segue, "nenhuma empresa industrial funciona por muito tempo sem lucro. Quando o ciclo de negócios se completa há um incremento no capital mediante o retorno do dinheiro, que pode ser parcialmente empregado novamente no incremento da produção." Isso leva Matias (2014, p. 187) a afirmar que "a Lei do Valor" vai sendo transformada em mera contingência, com a qual o designer tem que lidar no seu dia-a-dia profissional", e cita Mészaros (2002, p. 660-661) 37 $^{37}$ para quem “o capital define 'útil' e 'utilidade' em termos de "vendabilidade", um imperativo que pode ser realizado sob a hegemonia e no domínio do próprio valor de troca". Assim, Matias (2014, p. 187) postula que o capitalismo não é um modo de produção baseado no valor de uso, no qual o dinheiro seria apenas uma mediação na troca entre coisas (M-D-M), para a pura satisfação de carências humanas. Na verdade, o valor de troca é o motivo que impulsiona o modo de produção do capitalismo, que tem no dinheiro e no seu retorno (D-M-D) sua raison d'être. Assim, Matias (2014, p. 187) afirma que a relação entre valor de uso e satisfação de necessidades, tão enaltecida no Campo do Design, é apenas um momento determinado pelo processo de valorização do capital, de sua metamorfose nas etapas de produção e circulação. E complementa apontando que a união das esferas de produção e circulação consiste dos dois momentos da produção-realização do mais-valor, pois o valor de uso, ainda em sua manifestação subjetiva enquanto necessidade, já está subordinado ao valor de troca no momento da produção, afinal só é produzida aquela mercadoria cuja venda pareça ou já esteja garantida.

Deste modo, talvez possamos determinar que, a partir de Matias (2014), torna-se evidente um dos motivos pelos quais mercadoria parece ser um termo estranho ao Campo do Design, pois tenta-se apagar a dimensão econômica dos produtos - ou melhor, mercadorias - desenvolvidos pelo Campo. Ainda, a aproximação da prática do Campo do Design à noção de mercadoria de Marx, por quem iniciamos esse capítulo, contribui para a busca pela resposta ao nosso

\footnotetext{
${ }^{37}$ MÉSZÁROS, István. Para além do capital: rumo a uma teoria da transição. São Paulo: Boitempo/ UNICAMP, 2002.
} 
questionamento da experiência como mercadoria no Campo do Design: pelo aqui discorrido, talvez a experiência não possa ser uma mercadoria.

\section{3. \\ Metamorfoses contemporâneas}

Até aqui compreendemos — através de um desdobramento histórico que abarcou parte do século XX - o papel das mudanças na estrutura do modo de produção capitalista nas transformações ocorridas sobretudo em condições trabalho e na relação Arte, Cultura e Economia. Agora podemos, portanto, nos perguntar: as mudanças e transformações apresentadas e explicadas continuam até hoje? O que mudou? A seguir, vamos travar contato com textos contemporâneos, com o intuito de ampliar e problematizar nossos entendimentos.

\subsection{1. Manipulando felicidade}

William Davies (2016) ${ }^{38}$ discorre sobre as condições que fizeram com que governos - ele cita sobretudo seu país de origem e morada, a Inglaterra - e grandes empresas vendam hoje o bem-estar. A nós, interessa aqui compreendermos um pouco do desenvolvimento histórico dessas condições, posto que a comercialização de emoções e sentimentos estão imbrincadas ao Design de Experiência e podem nos ajudar a pensar, então, também a nossa questão. Davies (2016) concentra-se mais no por que, e não no como, governos e empresas vendem o bem-estar. Deste modo, usaremos apenas a parte inicial do livro - posto que nela ele identifica os principais desdobramentos desta prática - e trechos espaçados de outros capítulos para compreendermos seu argumento. O autor articula Psicologia e Economia e nos casos que ele apresenta podemos também identificar uma veia humanística, não obstante ele escancare que, em última instância - e talvez também em primeira , o que conta é o lucro, sobretudo ao apresentar tentativas já no século XIX de medir sentimentos através do dinheiro, como veremos em seguida. Com efeito, trataremos agora de algumas linhas gerais do estudo de Davies (2016), recortando

\footnotetext{
${ }^{38}$ DAVIES, Williams. The Happiness Industry: how the government and big business are selling us sell-being. Verso E-Book, 2016.
} 
apenas aquelas que nos ajudam a pensar a questão da experiência como mercadoria no Campo do Design.

Davies inicia seu livro The Happiness Industry: how the government and big business are selling us well-being (2016) narrando uma cena ocorrida durante o Fórum Econômico Mundial de 2014, em Davos. "Você não é o escravo dos seus pensamentos", informava ao público um homem com roupões vermelhos e amarelos, segurando um iPad. "Uma maneira é apenas olhar para eles... como um pastor sentado acima de um prado olha as ovelhas." Essas palavras, dentre outras similares, eram proferidas por Matthieu Ricard, um monge budista, todas as manhãs antes das atividades da conferência. Esse monge, considerado o homem mais feliz do mundo ${ }^{39}$, guiava bilionários e presidentes através de técnicas de meditação e relaxamento. Junto das meditações guiadas por Ricard, os participantes receberam um dispositivo que ficava preso ao corpo, constantemente enviando ao celular do participante informações acerca de sua saúde e atividades recentes: se o usuário não estava caminhando o bastante ou dormindo o bastante, ele era notificado. Assim, Davies (2016, p. 12-13) evidencia o que ele classifica como "a nova preocupação das elites globais": a felicidade. O autor afirma que a felicidade, em suas várias formas, não é mais apenas um complemento agradável à nossa sobrevivência econômica, ou uma preocupação acerca da idade para aqueles que têm tempo para tal. Como uma entidade mensurável, visível e inovadora, o autor considera que a felicidade penetrou a gestão econômica global e, assim, parece que o futuro bemsucedido do capitalismo passou a depender da nossa capacidade de combater o stress, a miséria e a doença, e enaltecer o relaxamento, a felicidade e o bem-estar. Ainda, ele afirma que técnicas, medidas e tecnologias estão agora disponíveis para conseguir isso, e elas permeiam o local de trabalho, as ruas, a casa e o corpo humano. Com efeito, Davies (2016, p. 18) escreve que este tema se tornou interesse não apenas de legisladores de nações (como os níveis de bem-estar social nacionais), mas também de administradores de empresas e cientistas - um movimento da chamada Psicologia Positiva, que dissemina técnicas e slogans através dos quais as pessoas podem aumentar e/ou melhorar sua felicidade no dia-

\footnotetext{
${ }^{39}$ De acordo com resultados de um estudo neurocientífico da Universidade de Wisconsin, que buscava compreender como diferentes níveis de felicidade estão inscritos e visíveis no cérebro. Em uma escala de extremamente infeliz $(+0.3)$ e extremamente feliz $(-0.3)$, Ricard marcou -0.45 , para a surpresa dos pesquisadores. Ver: CHALMERS, Robert. "Matthieu Ricard: Meet Mr. Happy". www.independent.co.uk, 18 February 2007. Acesso em 16 de Março de 2018.
} 
a-dia, sobretudo ao bloquear pensamentos e memórias negativas. Ainda conforme o autor, tais ideias chegaram até os currículos de escola ${ }^{40}$, onde acredita-se que alguns desses métodos possam treinar crianças sobre felicidade.

Davies (2016, p. 18-19) cita um crescente número de corporações que empregam funcionários responsáveis por disseminar atenção plena e empatia. Conforme o autor, esses profissionais - chamados consultores especializados em felicidade - aconselham os empregados a se animarem e os desempregados a restaurarem seu entusiasmo pelo trabalho. Por sua vez, a ciência também avança, com cientistas publicando pesquisas que identificam como a felicidade e a infelicidade estão fisicamente inscritas no cérebro, além de explicações neurológicas sobre por que certas atividades melhoram o nosso bem-estar. Ainda, inovações acerca do chamado "sujeito quantificado" correspondem a indivíduos que usam aplicativos de celular para rastrear seu humor e, assim, a chamada "Economia da Felicidade" recolhe dados e estatísticas — parte da chamada Big Data, recolhida gratuitamente a partir dos usuários — para construir imagens rentáveis acerca de regiões, estilos de vida, formas de trabalho e tipos de consumo que geram o bem-estar.

Logo, questões que antes eram subjetivas agora são consideradas de natureza objetiva e mensuráveis, e são respondidas racionalmente com a ajuda de dados. Entretanto, o principal problema de quantificar a felicidade é que esta não consiste de um fator que possa ser observado objetivamente, já que as emoções são experiências subjetivas e, por isso, o uso de fenômenos físicos quantificáveis para medi-la reduz a felicidade a uma simples utilidade. Segundo Davies (2016, p. 19), essa "Economia da Felicidade" conta ainda com a influência da Economia em si e da Medicina, sobretudo através de estudos interdisciplinares que pesquisam nossas atividades econômicas sem prestar muita atenção às questões filosóficas e subjetivas envolvidas. Além disso, o autor postula que os detentores das tecnologias que produzem os fatos sobre a felicidade estão em posição de influência, mas que são eles também influenciados pelas promessas dessas tecnologias.

\footnotetext{
${ }^{40} \mathrm{O}$ autor cita o projeto Penn Resilience Project, em que um time de psicólogos da University of Pennsylvania levam a terapia-cognitivo-comportamental à sala de aula. Em 2007, autoridades da Educação no Reino Unido enviaram 100 professores para visitar o projeto, com o intuito de recriálo em escolas.
} 
Com efeito, Davies (2016, p. 20) alerta que um dos problemas dessa iniciativa é colocar a culpa nos indivíduos que, medicados, são responsabilizados por sua própria tristeza, ignorando uma investigação do quanto o contexto pode ter influenciado - o autor afirma que taxas de distúrbios mentais estão sobretudo relacionadas à desigualdade de renda e não a outros fatores. Ainda, ele aponta que essa agenda tem interesses políticos e uma dimensão ideológica, sobretudo ao ser apresentada como nova, como solução para todos os problemas do passado que nos trouxeram até aqui. Davies (2016, p. 21-23) mostra que o interesse pelas emoções não é algo novo no pensamento humano: repetidamente desde o Iluminismo - e aceleradamente a partir do século XIX —, uma utopia científica vem sendo vendida, de que questões morais e políticas podem ser resolvidas com uma adequada ciência dos sentimentos humanos. Ainda, ele aponta que os que mais exploram essa agenda geralmente são aqueles interessados em controle social, seguidamente com vias de lucro privado - e é principalmente por causa disso que a indústria da felicidade avança.

Com efeito, Davies (2016, p. 33-34) postula que o conceito de felicidade como ferramenta de negócios e manipulação do governo remonta primeiramente ao século XVIII. Conforme o autor, o filósofo Jeremy Bentham (1748-1832), conhecido por sua vertente econômica utilitarista, argumentava que as políticas governamentais deveriam propiciar mais felicidade para o maior número de pessoas. Para isso, ele sugeriu que medissem os pulsos da população, a fim de revelar os sentimentos internos das pessoas. Davies (2016, p. 133) afirma que como desdobramentos desta frente surgiram os esforços de hoje para quantificar as emoções ao monitorar as frequências cardíacas, as ondas cerebrais e os movimentos oculares. Conforme o autor, Bentham defendeu o uso das vicissitudes do mercado como um modelo para a mente e seus desejos, e isso tomou força no século XIX, mais precisamente na década de 1870, com o teórico econômico William Stanley Jevons (1835-1882). De acordo com Davies (2016, p. 92), Jevons queria mostrar como o dinheiro poderia servir como um padrão emocional. O economista queria redefinir a noção de valor ao concebê-lo como um julgamento subjetivo que um consumidor alcança de forma independente, em vez da soma dos materiais e do trabalho empregados na produção de uma mercadoria. Como resultado, Davies (2016, p. 413) explica que muitos começaram a considerar os preços como um 
barômetro de atitudes e desejos públicos, mas que, para os economistas, rastrear quais itens provocavam preferências no consumidor já era o bastante.

Davies (2016, p. 159) cita ainda o behaviorismo como uma das origens para a situação que analisamos aqui. Conforme o autor, John B. Watson (1878-1958), presidente da Associação Americana de Psicologia, postulou em 1913 o behaviorismo, o qual afirmava que psicólogos não precisavam investigar os sentimentos dos pacientes: eles poderiam aprender tudo o que precisavam apenas observando as respostas das pessoas a vários estímulos. Segundo Davies (2016, p. 160-161), Watson eliminou os papéis de movimentos internos, desejos e percepções, declarando que ele poderia explicar todo o comportamento humano como resultado do condicionamento - e suas afirmações, obviamente, atraíram o interesse do campo da publicidade. Em 1920, Davies (2016, p. 162) conta que Watson se juntou à agência de publicidade J. Walter Thompson, onde atuou com a ideia de que a função de um anúncio efetivo não era exaltar o produto, mas sim "desencadear" emoções através de estímulos. Watson não se importava com o que os clientes desejavam, pois acreditava que ele poderia dizer o que eles queriam, orientando-os às emoções apropriadas.

Assim, Davies (2016, p. 122) postula que foi a partir desta expansão de métricas que surgiu o interesse em medir níveis de felicidade. Conforme o autor, se os economistas pudessem avaliar a felicidade, eles poderiam comparar os níveis de felicidade das pessoas com rendimentos diferentes e calcular uma correlação entre prazer e dinheiro e, com essa correlação como referência, estabelecer o valor monetário de "mercadorias" [grifo nosso] não comercializadas — como o ar limpo ou uma biblioteca - medindo o prazer que esses fornecem. Davies (2016, p. 123) afirma que autoridades britânicas já usaram essa técnica para determinar o valor das instituições culturais. ${ }^{41}$

Por conseguinte, Davies (2016, p. 23-24) arrazoa que talvez essa visão mecanicista do cérebro não seja a solução, mas sim uma das causas para a condição em que nos encontramos: na verdade, já somos o produto dos vários esforços em observar nossos sentimentos e comportamentos, pois gerentes de recursos

\footnotetext{
${ }^{41}$ Department for Culture, Media \& Sport. Understanding the Drivers, Impacts and Value of Engagement in Culture and Sport. www.gov.uk/government/publications, 2010. Acesso em 16 de Março de 2018.
} 
humanos, governos, publicitários e a indústria médica já vêm analisando e influenciando a dimensão psicológica humana desde o final do século XIX. Assim, o autor considera duas principais razões para essa preocupação com a felicidade no início do século XXI, e estas têm natureza sociológica. Conforme Davies (2016, p. 25), a primeira está ligada ao que ele considera a natureza do capitalismo. Citando um participante do supracitado Fórum Econômico Mundial de 2014, que afirmou "nós criamos os problemas que agora estamos tentando resolver" 42 , Davies afirma que o mesmo diagnóstico pode ser estendido à cultura - e aqui focamos mais precisamente nas condições de trabalho - do chamado, de modo equivocado, capitalismo pós-industrial. ${ }^{43} \mathrm{O}$ autor afirma que as empresas evidenciam o comprometimento comunitário e psicológico, mas que não investem em soluções econômicas efetivas a longo prazo, e complementa dizendo que temos um modelo econômico que mitiga contra justamente aqueles atributos dos quais ele depende, isto é, a força de trabalho humana. Segundo o autor, os economistas da felicidade colocam um preço no problema da miséria e da alienação, e um exemplo é uma pesquisa que aponta que a infelicidade de empregados custa à economia norteamericana $\$ 500$ bilhões por ano em perda de produtividade, recibos fiscais e custos de saúde. ${ }^{44}$

A segunda frente está relacionada ao desenvolvimento tecnológico, já que monitorar nosso humor e sentimento está virando uma função do ambiente físico, e não mais de instituições específicas, como laboratórios e hospitais. Davies (2016, p. 27-29) fornece o exemplo da British Airways que, em 2014, forneceu um "cobertor da felicidade" para seus passageiros. Este cobertor media a satisfação do passageiro através de monitoramento neural: quando o passageiro relaxava, o cobertor mudava de cor, do vermelho para o azul, o que indicava aos funcionários da empresa que ele estava sendo bem cuidado e estava satisfeito com o serviço que estava recebendo. Há também o caso do Facebook, que disponibiliza botões relativos a emoções para nossas interações - orientados por algoritmos. O autor

\footnotetext{
${ }^{42}$ CAMPBELl; SIMONS. At Davos, Rising Stress Spurs Goldie Hawn Meditation Talk. https://www.bloomberg.com/news/articles/2014-01-20/at-davos-rising-stress-spurs-goldie-hawnmeditation-talk, 21 January 2014. Acesso em 16 de Março de 2018.

${ }^{43}$ Reiteramos aqui que não julgamos correto o uso deste termo para definir o estágio do capitalismo hoje, conforme já explicitado na seção anterior.
}

${ }^{44}$ Gallup. State of the Global Workplace Report 2013. 2013. 
fornece ainda outro exemplo, do que ele chama de tecnologia de consumo: Vessyl, um copo inteligente (smart) que monitora a quantidade de líquido que seu usuário ingere por dia, a partir de parâmetros considerados saudáveis.

Davies (2016, p. 29) afirma que um dos argumentos fundacionais do neoliberalismo em favor do mercado é que este serve como um dispositivo sensorial, que captura milhões de desejos, opiniões e valores individuais e os converte em preços. Assim, o bem-estar, medido e manipulado, torna-se apenas um meio de alcançar lucros, status ou poder. Ele segue, afirmando que a preocupação liberal com a privacidade sempre recai na segurança, e que talvez essa quantidade considerável de vigilância deva ser balanceada.

Por fim, Davies (2016, p. 30-31) afirma que enxergar essa situação pelo viés histórico e sociológico não necessariamente indica uma resposta, mas muda o foco para fora, para o contexto em que a situação ocorre, político e econômico, e não para dentro, para sentimentos, cérebros e comportamentos - e é isso que devemos fazer para tentar compreender a experiência como mercadoria no Campo do Design.

Deste modo, vimos com Davies (2016) as razões e os desdobramentos da industrialização de um sentimento humano - e essas razões e desdobramentos não estão no sentimento em si, mas sim nas ações e condições concretas de vida que o permeiam, sobretudo o modo econômico dominante. Ainda que Davies também não explique o que considera uma mercadoria, nem afirme com veemência que a felicidade é uma mercadoria, seus apontamentos nos ajudam a direcionar nosso questionamento sobre a experiência como mercadoria no Campo do Design e sua posterior resposta ao indicar-nos essa necessidade de visão extra-campo e já nos apontar algumas razões e desdobramentos que podemos fazer convergir entre experiência e sentimentos, agora com valor econômico.

\subsection{2.}

\section{Obsolescência e virtualidade}

Sementes programadas para o suicídio, serviços de streaming de músicas e filmes e ações em jogos online que permitem roubos no mundo offline: esses são alguns 
exemplos que Sebástien Chauvin e Olga Sezneva $(2014)^{45}$ fornecem para discutir novos tipos - ou novas formas - de mercadoria e questionar a já discutida suposta virtualidade/imaterialidade do capitalismo hoje. Ao examinar como as estratégias recentes de mercantilização respondem aos desafios colocados por conteúdos digitais e outros conteúdos autorreprodutíveis, os autores afirmam que se torna evidente que os limites - ou a ausência deles — à mercantilização não vieram da intangibilidade per se, mas sim de formas de inscrição física associadas a custos insignificantes de reprodução, compartilhamento e transmissão. Segundo Chauvin e Sezneva (2014, p. 125), essas formas de inscrição exigem próteses cada vez mais onerosas para garantir a manutenção das mercadorias, o que acaba por conferir importância à sua forma física, propiciar possíveis novas formas de manipulação e ocasionar o que consideram a sua obsolescência, ou seja, a forçada e prolongada manutenção da mercadoria diante do que eles consideram a sua insuficiência histórica, ou seja, que talvez a forma como elas se apresentam hoje para nós não seja mais condizente com nosso futuro econômico. Eles tentam responder à pergunta: qual papel a chamada "economia de conhecimento" tem na produção de produtos cada vez mais difíceis de mercantilizar?

Chauvin e Sezneva (2014, p. 126) principiam a discussão afirmando que não é nova a sugestão de que mudamos de uma época de mercadorias tangíveis para intangíveis, e de que estamos avançando para uma "sociedade da informação" ou vivendo na "era digital". Os autores afirmam que muitos argumentaram que a constituição da base da produção hoje não é mais o motor a vapor, mas o software: fluxos de mensagens e imagens entre redes constituem agora o fio básico da vida social e econômica; e dão exemplos: livros já não ocupam espaço na casa ou no escritório, eles ordenadamente se encaixam no Kindle ou no iPad, e a entrega de jornal a domicílio deu lugar ao download de aplicativos. Ainda, indicam que indústrias de propriedade intelectual intensiva são um terço do produto interno bruto dos EUA. ${ }^{46}$

\footnotetext{
${ }^{45}$ CHAUVIN, Sébastien; SEZNEVA, Olga. Has Capitalism Gone Virtual? Content Containment and the Obsolescence of the Commodity. In.: Critical Historical Studies, no. 1 (Spring 2014).

${ }^{46}$ Economics and Statistics Administration and United States Trademark and Patent Office, U.S. Department of Commerce, Intellectual Property and the U.S. Economy: Industries in Focus. www.uspto.gov/about/ipm/industries_in_focus.jsp, March 2012. Acesso em 16 de Março de 2018.
} 
Entretanto, Chauvin e Sezneva (2014, p. 128) consideram que o capitalismo não se tornou "imaterial" recentemente: "irredutível à riqueza" e com uma relação política de extração de mão-de-obra, o capital nunca foi localizado na fisicalidade dos objetos e, portanto, neste sentido, sempre foi imaterial" ${ }^{47}$ Entretanto, devemos atentar aqui para o fato de que apesar do valor e do capital serem considerados imateriais - conforme já vimos com Marx —, o capitalismo opera sobre bases de produção concretas e, nisto, a materialidade se sobrepõe e é condição de existência à imaterialidade supracitada. Além disso, eles afirmam que o trabalho e a sua extração sempre envolveram mais do que esforço físico individual: eles sempre incluíram know-how, inteligência coletiva, sentimentos e outras competências humanas. Assim, Chauvin e Sezneva (2014, p. 128) postulam que dizer que uma economia é baseada no conhecimento não significa que a atividade econômica usa mais conhecimento do que antes, mas sim que o conhecimento se tornou um bem econômico que, em condições alteradas, pode circular como tal.

Conforme Chauvin e Sezneva (2014, p. 127), alguns autores consideram que o trabalho e o capital - as principais forças motrizes da sociedade industrial — foram substituídos por fluxos de conhecimento e informação dentro de um novo "modo de desenvolvimento informacional." ${ }^{48}$ Embora o regime através do qual a sociedade de hoje produz excedentes e através do qual este excedente é expropriado e acumulado como capital ainda deveria ser chamado de "capitalismo", os autores afirmam que, para alguns, o próprio regime teria entrado em sua "fase cognitiva." ${ }^{49}$ Assim, eles consideram que esses paradigmas, ao incorporarem o intangível e o virtual às esferas de produção e troca, buscam capturar a inclusão de mundos vitais ainda não afetados no ciclo de acumulação de capital.

Como, então, abordar a relação entre digitalização e mercantilização? Qual o significado que se deve atribuir a esta mediação para a forma de mercadoria em

\footnotetext{
${ }^{47}$ Os autores afirmam que seu argumento exige reiterar a distinção clássica entre a materialidade da física e a materialidade da práxis: como distinto dos objetos de mercadoria, a forma da mercadoria sempre foi 'imaterial' no sentido anterior e 'material' no último. Assim, escolhemos usar palavras como 'físicas' e 'tangíveis' para se referir a propriedades tanto da matéria de conteúdo quanto das tecnologias de mercantilização, de modo a distinguir a fisicalidade da materialidade mais ampla das relações sociais.
}

${ }^{48}$ CASTELLS, Manuel; CARDOSO, Gustavo. The Network Society: From Knowledge to Policy. Washington, DC: John Hopkins Center for Transatlantic Relations, 2006.

49 MOUliER-BOUTANG, Yann. Cognitive Capitalism. Cambridge: Polity Press, 2012; LAZZARATO, Maurizio. Immaterial Labour. In.: Virno and Hardt, Radical Thought, 1996. 
si? Pra responder a estas questões, Chauvin e Sezneva (2014, p. 132) discutem instâncias relevantes do processo de mercantilização hoje: conteúdo de mídia digital (música, filmes e software) restringido tanto pelo aparelho de propriedade intelectual (IP) quanto pelos dispositivos físicos sob o termo guarda-chuva da digital rights management (DRM); tecnologias de restrição de uso genético (GURTs), como as desenvolvidas pela Monsanto e algumas outras corporações do agronegócio e, finalmente, troca de mercadorias e pirataria em jogos denominados massively multiplayer online games (MMOs), como o mundo virtual do Second Life. Antes de prosseguir, eles afirmam que seu inquérito se baseia na política jurídico-ecológica da reprodutibilidade, e não na discussão acerca de imaterialidade ou virtualidade, pois, ao contrário das crenças comuns sobre economias "virtuais", suas capacidades transbordantes não provêm de sua intangibilidade pura e simples, mas sim do modo peculiar de sua inscrição tangível. Assim, eles afirmam que, no nível empírico, as tecnologias discutidas são desenvolvidas para ostensivamente manter e proteger a forma da mercadoria no contexto de um ambiente de mudança gerado pelo próprio desenvolvimento do capitalismo: em seus termos, as próteses não estão lá apenas para gerenciar uma desvantagem estática, mas sim para se adaptar a mutações ambientais para que um determinado artefato sociotécnico - a mercadoria - perdure.

Como primeiro exemplo, Chauvin e Sezneva (2014, p. 134) consideram que os bens de mídia têm duas características principais: são de natureza intangível e não degradam com o uso. Entretanto, como essa intangibilidade e seu uso são transformados em mercadorias? Os autores afirmam que bens de mídia têm o conteúdo digital "líquido" (sic.), o qual é envolto por diferentes embalagens, cujas mudanças nas formas de realização física mostrou-se, desde 1940 nos EUA, como método-chave para a geração de lucro: de vinil para criptografia de arquivos, e utilizando distintos equipamentos de reprodução. Hoje, entretanto, o método-chave para o controle, segundo os autores, são os direitos autorais - para além, é claro, da materialidade de computadores, celulares e dispositivos que tocam música ou exibem filmes, mas estes não são necessariamente responsáveis pelo controle, e sim, sobretudo, pela possibilidade de uso.

Com efeito, Chauvin e Sezneva (2014, p. 135) afirmam que desde 20032005, houve uma grande mudança na estrutura do consumo de bens culturais, posto que conteúdos digitais passaram a circular cada vez mais como arquivos digitais. 
Os discos ópticos (CDs e DVDs) vêm perdendo sua posição nos mercados legais e ilegais para downloads da Internet, serviços de transmissão como Spotify ou Pandora, e televisão on-demand, não obstante nem todos tenham acesso a esses serviços: o streaming depende da existência de uma infraestrutura de transmissão completa e, portanto, é limitado ao núcleo industrial global e às áreas urbanas onde uma conexão suficiente é disponível. Entretanto, como e quem faz o controle destes arquivos e streamings? Chauvin e Sezneva (2014, p. 135) afirmam que a possibilidade de esses conteúdos "sangrarem" para fora da zona de controle das indústrias é muito grande e muito recorrente, além de serem apropriados e transmitidos com menor ou nenhuma distorção, e que, por isso, devem ser controlados. É neste cenário, portanto, que instituições de direitos autorais (IP) e serviços de streaming tomam a frente. Os autores afirmam que as indústrias de mídia e entretenimento intensificaram suas tentativas de eliminar qualquer lacuna que não seja coberta por medidas de contenção institucional, incluindo tecnologias antipiratarias em todos os softwares e hardwares que processam conteúdo de entretenimento digital e investem milhões de dólares em tecnologias para evitar infrações durante transmissões públicas e concertos.

Ainda, os chamados sistemas DRM (digital rights managements), ou gerenciamento de direitos digitais, o supracitado termo guarda-chuva que se refere a qualquer tecnologia que controle o acesso a material protegido por direitos autorais de "dentro", cresceram a partir do final da década de 1990. Tomando como exemplo os DVDs com códigos de região, criptografados para serem reproduzidos apenas em equipamentos específicos, os sistemas DRM hoje se aproximam mais do que é considerado um "spyware" 50 , porque, para serem efetivos, eles precisam estar escondidos do usuário, acabando por comprometer a segurança do computador de uma forma mais geral. Assim, Chauvin e Sezneva (2014, p. 137) ainda postulam que através de DRMs, intervenções de direitos autorais implantam códigos no corpo material do objeto de mercadoria para controlar sua circulação, e que detectores de câmeras e dispositivos DRM funcionam como próteses tecnológicas, tanto externa ou internamente à própria matéria do conteúdo. Logo,

\footnotetext{
${ }^{50}$ Programa automático de computador, que recolhe informações sobre o usuário, sobre os seus costumes na Internet, e transmite essa informação a uma entidade externa, sem o conhecimento e consentimento do usuário.
} 
são extensões de dispositivos jurídicos e institucionais de contenção de conteúdo e, como tal, eles sinalizam uma fisicalização protética da mercadoria.

Em seguida, para tratar das sementes suicidas, Chauvin e Sezneva (2014, p. 139) principiam por informar que em 1998, o Serviço de Pesquisa Agropecuária do Departamento de Agricultura dos Estados Unidos, junto com a Delta e Pine Land Company, obteve a patente de uma semente geneticamente modificada chamada "controle da expressão genética de plantas", a qual foi apelidada de Terminator. A semente Terminator cresce como uma planta estéril, o que faz com que os agricultores que a utilizam não sejam tecnicamente capazes de guardar as sementes para o próximo ano. Em vez disso, eles têm de voltar ao produtor para comprar novas sementes, ano após ano. Chauvin e Sezneva (2014, p. 139) consideram que agricultores sempre foram capazes de repor suas próprias sementes para produzir novas culturas, mas que com a comercialização e plantio das sementes geneticamente modificadas a partir da década de 1990, seu trabalho tomou uma nova direção. Como o desenvolvimento das sementes geneticamente modificadas requeria um forte investimento financeiro e humano, a atividade de patentear acabou sendo destinada a proteger esse investimento contra o que mais tarde o Departamento de Agricultura dos EUA chamou de "regeneração não autorizada." Conforme Chauvin e Sezneva (2014, p. 139-140), ao ir além da lei federal, algumas empresas agrotécnicas que desenvolvem sementes geneticamente modificadas como a Monsanto exigiram que os agricultores assinassem um "acordo de tecnologia" - também apelidado de "cláusula Terminator" — no qual eles se comprometiam a não guardar as sementes resultantes da sua cultura transgênica. Os autores afirmam que policiar esta cláusula é complexo, pois os desenvolvedores de sementes devem enviar agentes para os campos dos agricultores para colher amostras de culturas, procurando usuários sem licença de semente proprietária. Quando tais utilizações são encontradas, procedimentos legais dispendiosos são necessários para deter o uso, forçar a aceitação de uma licença ou recuperar royalties não remunerados.

Com efeito, Chauvin e Sezneva (2014, p. 140) consideram que até que essa tecnologia fosse inventada, "as sementes não conseguiam se tornar mercadorias puras, posto que sua troca também transferia os meios de produção", pois, pelo menos no caso de plantas autopolinizadoras, as sementes se reproduzem por sua própria iniciativa. Assim, considera-se que a tecnologia Terminator aumentou 
significativamente o alcance do controle corporativo sobre a reprodução livre, evitando o uso da semente como capital. Logo, as corporações passaram a manter um "monopólio biológico" sobre as plantas que vendem.

Segundo Chauvin e Sezneva (2014, p. 141), desde o início dos anos 2000, o mundo assistiu a um aumento do patenteamento de artigos agrícolas orgânicos, o que contribuiu para a solidificação de um oligopólio global: em 2009, 85\% das patentes transgênicas de milho estavam concentradas nas três principais empresas de sementes Monsanto, DuPont e Syngenta. Em 2012, a última controlou 53\% do mercado global de sementes comerciais. Nos Estados Unidos, 93\% da soja e $86 \%$ do milho vieram de sementes patenteadas geneticamente modificadas. ${ }^{51}$ Os autores complementam que as estratégias se tornaram variadas, havendo até casos como o da Syngenta que obteve, em 2004, uma patente sobre uma tecnologia para desenvolver sementes de batata que se tornariam estéreis a menos que fossem tratadas com produtos químicos. Deste modo, os autores citam o ponto de vista de uma analista chave desses desenvolvimentos: "a pesquisa contínua e o contínuo interesse comercial em sua aplicação sugerem que é uma questão de quando, e não se, a tecnologia será implantada." 52

Já sobre jogos, Chauvin e Sezneva (2014, p. 142-143) consideram que o próprio código toma a frente como mercadoria - não obstante seja importante lembrar aqui da materialidade do computador ou dispositivo necessário para que este seja acessado e jogado. Estes jogos são chamados MMOs, massively multiplayer online games, e seus proprietários corporativos não necessariamente faturam a partir de assinaturas, mas sim através de microtransações de bens virtuais: por exemplo, armas para que os usuários possam ter mais sucesso no jogo ou para alcançar outro nível. Second Life é um exemplo de MMO: o jogo consiste de um grande mundo virtual de simulação 3D, criado no início dos anos 2000 pelo Linden Lab, o qual conta com a média de 1 milhão de visitas mensais e 36 milhões de

\footnotetext{
51 Center for Food Safety, Seed Giants vs. U.S. Farmers. http://www.centerforfoodsafety.org/reports/1770/seed-giants-vs-us-farmers., 13 February 2013. Acesso em 16 de Março de 2018.

${ }^{52}$ BURK, Dan L. Legal Constraint of Genetic Use Restrictions Technologies. In.: Minnesota Journal of Law, Science \& Technology, 2004.
} 
contas criadas durante os primeiros 10 anos de existência (2003-13). ${ }^{53}$ No Second Life, um jogador assume a forma de um avatar, uma personalidade online em um mundo sintético. $\mathrm{O}$ avatar interage com outras pessoas através de mensagens, pode comprar propriedades, construir edifícios, possuir lojas, participar de festa, entre outras ações. Para jogá-lo, o usuário deve fazer o download do software gratuitamente: não é necessário pagar apenas para navegar pelo jogo, mas para obter uma aparência, roupas, uma casa e conhecer pessoas faz-se necessária a compra da moeda virtual - o Linden - que pode ser trocada por dólares, euros e outras moedas.

No Second Life, como em outros MMOs, as fronteiras entre o mundo real e o mundo virtual não são tão claras como parecem. Conforme Chauvin e Sezneva (2014, p. 145), os objetos comercializados por avatares podem ser códigos de computador, mas o valor gerado por essas transações, bem como as próprias transações, acontecem no mundo real — do qual o mundo virtual é parte. Os autores informam que em 10 anos, as transações de bens virtuais entre usuários do Second Life totalizaram US\$ 3,2 bilhões, por 1,2 milhão de transações diárias em 2013. ${ }^{54}$ É por este motivo que empresas fazem parte do jogo: segundo Chauvin e Sezneva (2014, p. 145-146), em seu apogeu, em 200755, o Second Life atraiu lojas da American Apparel, Adidas e IBM a seu mundo virtual, bem como contou com bancos financiando suas operações, como o Wells Fargo e $B C V$, um dos maiores bancos regionais da Suíça. Ainda, através do jogo é possível enviar mensagens de texto para telefones no mundo "real", ou comprar em lojas que vendem bens reais utilizando a moeda Linden. Todas as moedas desses jogos têm taxas de conversão específicas, embora muitas sejam relatadas como arbitrárias. Os autores relatam a falta de regras em alguns jogos, como o caso do jogo Eve Online: em 2010, um jogador conseguiu assumir a empresa de investimento Titans $4 U$, roubou toda a

\footnotetext{
53 WALKER, Chris. Second Life's Strange Second Life. In.: The Verge. http://www.theverge.com/2013/9/24/4698382/second-lifes-strange-second-life, 2013. Acesso em 16 de Março de 2018.

54 Second Life Celebrates 10-Year Anniversary. In.: Press Release Archive, Linden Lab, http://lindenlab.com/releases/second-life-celebrates-10-year-anniversary. 20 June 2013. Acesso em 16 de Março de 2018.

${ }^{55}$ Hoje considera-se o Second Life como defasado, com poucos acessos e usuários, sobretudo em virtude da necessidade de utilizar dinheiro real para ações no jogo.
} 
reserva desta na moeda Eve Online - o InterSteller Kredit, ou ISK - e embolsou US\$ 45.000. Como tal prática não era ilegal, nada pôde ser feito.

Conforme Chauvin e Sezneva (2014, p. 147), os MMOs parecem ser o espaço de valorização por excelência, porque o controle sobre o uso nunca se esgota: a lei do código constitui o próprio espaço dentro do qual a mercadoria é usada. Assim, em vez de ser incorporada à fisicalidade, a forma da mercadoria é cosmologizada no espaço do jogo, tornando-se simultaneamente matéria e lei do mundo. Com efeito, Chauvin e Sezneva (2014, p. 149) apontam que a maioria das práticas econômicas nos mundos sintéticos exploram a dinâmica de mercantilização em vez de subvertê-la, posto que o mercado "interno" do jogo está intrinsicamente ligado ao mercado "externo" do mundo. Logo, os mundos sintéticos nunca podem ficar completamente afastados da inscrição física de bens virtuais. Nessas configurações, os autores consideram que a necessária mediação física da circulação da mercadoria, combinada com a reprodução de bens virtuais a custo zero, permitiu que o último exista, transfira e multiplique em formas que escapam ao plano restrito de valorização do capital.

Assim, Chauvin e Sezneva (2014, p. 143) consideram que a mercantilização bem-sucedida não exige apenas a contenção efetiva do conteúdo, mas também a crença social na identidade ontológica entre forma e conteúdo, já que o fetichismo da mercadoria implica a percepção mistificada de mercadorias enquanto objetos contidos. Deste modo, para os autores, talvez as novas tecnologias de contenção de conteúdo possam aproximar a forma da mercadoria da sua desfetichização, uma vez que essas tecnologias evidenciam a arbitrariedade desta contenção. Os autores complementam que, na verdade, mais do que o inchaço de contenção puramente legal, a contenção tecnológica trai a condição de artefato da mercadoria como uma forma historicamente arbitrária, pois à medida em que o trabalho de contenção se torna mais intenso e tecnologicamente mais mediado, e implica em mais e mais modificações sofisticadas de conteúdo, ele perde gradualmente sua naturalidade ideológica. Chauvin e Sezneva (2014, p. 143) afirmam que a forma institucional não pode mais aparecer como única com o conteúdo que ela envolve e contém ou como a forma natural do conteúdo. Ou, pelo contrário, pode igualmente parecer uma astúcia do fetichismo da mercadoria, através da qual a ilusão de naturalidade seria permitida para reiterar-se projetando-se sobre a objetividade tecnologicamente modificada. 
Assim, Chauvin e Sezneva (2014, p. 143-144) afirmam que o fato da fisicalidade representar um problema para a mercantilização é parte integrante da história política da mercadoria, e que os bens de mídia têm ilustrado este paradoxo de forma original: sua inscrição física, ao invés de sua suposta natureza imaterial, tem sido a fonte de sua livre reprodutibilidade sem mediação capitalista e, portanto, sem extração de valor. Com efeito, é o meio físico, e não o conteúdo intangível, que permite a cópia. Logo, conforme os autores, a mediação física é ao mesmo tempo uma condição de possibilidade da circulação da mercadoria e um Calcanhar de Aquiles para a sua forma, e isso ocorre porque o espaço material de uso do conteúdo, valorização e circulação não é inteiramente controlável pela corporação ou entidade que comercializa o produto.

Por fim, Chauvin e Sezneva (2014, p. 150) concluem que esses desenvolvimentos não indicam o "fracasso" da mercadoria, mas sim as tentativas cada vez mais onerosas para perpetuá-la. Segundo os autores, quando bemsucedida, a expansão da mercadoria nas esferas cognitiva e criativa, combinada com o desenvolvimento exclusivo de seus aparelhos de contenção legais e tecnológicos, sinaliza o poder cada vez maior do capital para mercantilizar. Então, citam Marx:

Em uma certa etapa do seu desenvolvimento, as forças produtivas materiais da sociedade entram em conflito com as relações de produção existentes, ou - o que é apenas uma expressão legal para a mesma coisa — com as relações de propriedade que estiveram em trabalho até agora. ${ }^{56}$

Comentam, ainda, que hoje, o enorme inchaço das medidas jurídicas e tecnológicas desenvolvidas para estabilizar o conteúdo e limitar a satisfação das necessidades, o aumento de seu custo econômico e a crescente quantidade de energia social coletiva que desperdiçam inutilmente, podem falar da obsolescência iminente da forma-mercadoria: não tanto do seu declínio social real como da sua inadequação histórica cada vez mais evidente através da manutenção forçada e prolongada.

\footnotetext{
${ }^{56}$ MARX, Karl. Preface to A Contribution to the Critique of Political Economy. In.: The MarxEngels Reader, 2nd ed., ed. Robert C. Tucker. New York: Norton, 1978.
} 
Como vimos, Chauvin e Sezneva (2014) trazem novos e variados exemplos para a nossa discussão acerca do que é uma mercadoria hoje. Evidenciando um determinismo tecnológico nas distintas áreas abarcadas - jogos, sementes e arquivos digitais — os autores acabam por evidenciar também a presença maciça da busca por lucro em nossa sociedade. Ao postularem ainda a obsolescência da forma-mercadoria, trazem um novo viés para a questão, de que talvez o modo de produção do capitalismo não consiga sustentar suas formas por muito tempo, ou tenha que modificá-las a fim de manter a acumulação. Em relação a nossa questão da experiência, parece evidente que a relação entre forma e conteúdo, tangível e intangível, deva ser considerada. Mas como pensar essa relação na considerada experiência no Campo do Design? 


\section{4. CRÍTICA DA EXPERIÊNCIA COMO MERCADORIA NO CAMPO DO DESIGN}

Devemos começar a parte final deste estudo determinando, antes de mais nada, nosso entendimento e posicionamento crítico. Buscamos aqui descrever a forma de funcionamento das noções de experiência e mercadoria - sobretudo em sua contenção no, mas também extrapolação do, Campo do Design - , bem como as suas condições de possibilidades, as suas contraditoriedades e os seus desdobramentos históricos. Deste modo, buscamos o conhecimento sobre como essas condições surgiram, que forças as perpetuaram e quais as possibilidades de desenvolvimentos críticos futuros.

Deste modo, vimos até agora como a experiência no Campo do Design é definida e limitada por um determinismo tecnológico que não leva em conta as idiossincrasias do usuário que experiencia. Também vimos que a forma elementar da mercadoria, descrita no século XIX, se mantém até hoje, porém com distintos conteúdos e formas. Com efeito, o questionamento que fundamenta esta pesquisa — pode a experiência no Campo do Design ser uma mercadoria? — será discutido agora, após termos percorrido todo o caminho de fundamentação. Primeiramente, discorreremos criticamente sobre a noção de experiência e, depois, desta como mercadoria.

\section{1.}

\section{Projetando ainda formas e usos}

Devemos principiar pela definição do que entendemos por experiência, entendimento este diferente do hegemônico no Campo do Design. Já vimos no Capítulo 2 - Da experiência, a insuficiência e o equívoco da noção de experiência no Campo em questão, que almeja - como com Hassenzahl (2011), Norman (2013), Pine e Gilmore (2013) - abarcar a totalidade da experiência humana, porém, se restringe sobretudo a experiências mediadas pela tecnologia, ou, se 
preferirmos, experiências tecnológicas. Por mais que não queiramos ditar aqui uma definição única de experiência - tendo em vista todo seu percurso histórico e político estudado com Jay (2006) —, temos que partir de algum lugar, e este lugar será o de reconhecer seus significados cambiantes e sua conceituação enquanto construção social.

Deste modo, postulamos aqui que seguiremos as diretrizes de Scott (1991), a qual apresenta alguns pontos em comum com Williams (1976), para quem a experiência é uma categoria de construção social, constituída historicamente, que evidencia a ideologia do contexto e as idiossincrasias daquele que experiencia. Ainda, ela é variável - nunca uma constante apenas perceptual, nem algo inalterável ou metafísico. Além disso, a autora postula que não devemos pensar a experiência como algo que as pessoas simplesmente têm, como apenas uma realidade vivida, mas sim perguntar como essas experiências são produzidas, reconhecendo as particularidades de concepções, sujeitos, identidades, culturas o que já percebemos ser ignorado ou homogeneizado no Campo do Design. Logo, não considerar a experiência somente como existência interna - expressão do ser ou consciência de um indivíduo - , nem somente como externa - o material sobre o qual a consciência age, efeito de condições ou crenças sociais - , mas sim a relação de construção social e histórica entre ambas. Este é o direcionamento que devemos tomar, posto que amplia nossa capacidade e possibilidade de entendimento. Assim, queremos pensar a experiência como algo que não é evidente nem direto, algo que pode ser sempre contestado - portanto, algo político - e o qual deve contestar seu status — o que os pares do Campo do Design não fazem.

Podemos também recorrer a Jay (2006, p. 5-6), que adverte que a palavra experiência costuma ser usada para sinalizar precisamente o que excede conceitos e mesmo a própria linguagem, sendo empregada frequentemente como um marcador que não pode ser traduzido em termos convencionalmente comunicativos - o que não inviabiliza seu entendimento como uma construção social, mas sim soma para a sua compreensão enquanto algo humano. Logo, embora possamos tentar compartilhar ou representar o que experienciamos, considera-se que apenas o sujeito realmente sabe o que ele experimentou. Jay (2006, p. 383) advoga, ainda, por um entendimento da experiência não como meramente uma categoria mental, mas uma dimensão somática do ser humano. 
Com efeito, se formos compreender a experiência no Campo do Design a partir dessas diretrizes, grande parte das concepções recorrentes e apresentadas no Capítulo 2 - Da experiência caem por terra. Mesmo que algumas advoguem por um entendimento para além da determinação tecnológica - como citado ao início deste subcapítulo - quando nos deparamos com os exemplos dados e o modo de projetar, elas não se sustentam. Além disso, torna-se evidente que o trabalho de projeto da/para a experiência também se mostra insuficiente, posto que, conforme já vimos com Redström (2006), o que projetamos ainda é o objeto e, no máximo, o usuário - como um Design de usuário. O objeto, porque todos os exemplos fornecidos — o acordar com o despertador, a mensagem no celular — ainda necessitam da materialidade física para ocorrer. Mesmo que busquemos exemplos "mais intangíveis", como o streaming de música e os jogos apresentados por Chauvin e Sezneva (2014) no Capítulo 3 - Da mercadoria, ainda assim esses dependem também de dispositivos e computadores para ocorrerem, ou melhor, existirem. Hassenzahl (2011) fala do objeto como mediação da experiência — para nós, ele se configura como a condição para a experiência, e não apenas uma mediação. Ainda, Redström (2006) postula a impossibilidade de se projetar para algo que não existe, daí também a necessidade primeira do objeto - aqui, sobretudo tecnológico e interativo - e daí que projetamos o objeto, ou para o seu uso, e não a experiência, a qual é uma decorrência, uma consequência do uso deste objeto.

Seguindo Redström (2006), devemos agora discutir a questão do usuário. Desde os anos 1970, temos uma suposta preocupação com o usuário: primeiramente, com os supracitados estudos de IHC; depois, a linha intitulada Design centrado no Usuário; e mais contemporaneamente, a que é conhecida por ter suplantado o Design centrado no Usuário, por ir além da usabilidade e reconhecer as reais necessidades dos usuários, o Design de Experiência do Usuário. Empregamos o adjetivo suposta a essas frentes porque, na verdade, elas não passam de termos vazios. Ainda que mudanças em metodologias e em resultados de projeto procurem provar essa preocupação, no cotidiano são escassas as empresas que realmente consultam o usuário, sem considerar que mesmo essa consulta pode acabar sendo direcionada para o que se busca evidenciar, isto é, para corroborar aquilo que o projeto já está direcionado a desenvolver, seja com base na tecnologia existente ou em todos os âmbitos, de acordo com o desejado pelos donos do capital 
financeiro. Ainda que se projetasse considerando o usuário - seguindo a ideia da construção social que aqui tomamos para a definição de experiência —, o máximo com o que nos depararíamos seria uma possível inadequação a algumas especificidades e idiossincracias. O leitor atento poderia afirmar que tal como na Arte, o Gesamtkunstwerk ${ }^{1}$, o utópico Design Universal, pode ter sido suplantado pelas técnicas de Design Participativo, por exemplo, em que a ideia de usuário seria mais flexível e pontual. Entretanto, mesmo nesses projetos, recorremos a Redström (2006), quando ele afirma que o pensamento acerca do usuário é quase sempre uma especulação, não conhecimento propriamente dito. Redström (2006) nos auxilia em mais um ponto, ao postular que na verdade não projetamos para o usuário, mas sim projetamos o usuário, e esse é geralmente um usuário anônimo, pasteurizado, apolítico, inexistente - mas que acaba nos dando um entendimento político do Campo a partir desta própria definição. Ainda, devemos lembrar do cambiante uso de distintos termos para a noção de usuário - cliente, consumidor, indivíduo, pessoa, sujeito. Tal falta de rigor no emprego dos termos evidencia que seu determinismo tecnológico é insuficiente, além de comprovar uma posição do Campo de preferência por definições não claras, que deixam margem para adições e subtrações de acordo com a ocasião. De nossa parte, pensamos que para o desenvolvimento de um pensamento sério e crítico sobre a prática do Design, é necessário que as definições dos termos empregados sejam claras, indicando seus espaços e limites.

Deste modo, devemos atentar também ao fato de que se emprega o termo usuário para quando na verdade estamos tratando sobretudo de consumidores, aqueles que adquirem as mercadorias e os serviços comercializados pelo Campo do Design. O usuário é compreendido como um ser passivo, como a árvore do ficus microcarpa na mão de um topiário. Não tem entranhas, não resiste, enfim, não se manifesta e, portanto, nunca há o contraditório - além de consistir, sobretudo, de uma adaptação e ajuste ao objeto e uso projetados, isto é, de aparentemente não ter espaço para ação individual, própria.

Assim, podemos considerar que tanto a vertente teórica humanista quanto a orientada pelo mercado se mostram insatisfatórias quanto à questão do usuário, uma vez que 1) não reconhecem a abstração que é o usuário que projetam (e não para o

\footnotetext{
${ }^{1}$ A noção Obra de Arte Total, de acordo com o romantismo alemão do início do século XIX e especialmente com Wagner e sua ópera.
} 
qual projetam); 2) tolem totalmente a "liberdade" que teoricamente almejam dar ao usuário por fazê-lo se encaixar em modos e categorias de uso. Nesta linha da falta de "liberdade", outro ponto que gostaríamos de pensar é sobre a experiência como experimento e como contrário de inocência, conforme vimos, respectivamente, nas definições etimológicas e na concepção de Blake (1789) da experiência e da inocência como dois estados contrários da alma no Capítulo 2 - Da experiência. $\mathrm{O}$ Campo do Design parece não deixar espaço para a experimentação, nem para, digamos, um usuário experiente. Parece que somos sempre pessoas que precisam de diretrizes para operar objetos - obviamente que qualquer objeto, por não ser de entendimento universal e intuitivo, requer instruções de uso, algumas que se naturalizam ao longo de nossa vida depois de aprendermos durante a infância, pois o significado e a função não são intrínsecos à forma, mas sim definidos pelo significado e uso que damos a eles. Entretanto, no Campo do Design parece haver um zelo - ainda que irreal - a esse suposto usuário, que nada mais é que uma abstração - , e esta abstração quase sempre é inocente, dificilmente experiente.

Sobre a abstração, faz-se necessário considerarmos que designers acabam acreditando que as categorias abstratas que eles criam para seus projetos são iguais à realidade que elas deveriam representar. Eles esquecem que são suposições, não essências ou verdades, do que representam. Devem ser consideradas como hipóteses teóricas que precisam ser provadas ou refutadas em sua aplicação. Contudo, não obstante a abstração seja necessária para a compreensão, para a concepção, ela sempre deixa algo de fora. Conforme Ijlal Muzaffar $(2015)^{2}$, a Arte desenvolveu um vocabulário para apontar silêncios, ausências, para indicar que existe algo fora do seu quadro. Entretanto, grande parte dos designers não desenvolveram, ou desenvolvem, estratégias de representação que possam reconhecer que algo é deixado de fora, que há um limite para o que o Design pode fazer em uma situação particular. Logo, quando projetos não alcançam seus objetivos declarados, temos como resultado uma culpa imposta aos usuários, e não a culpa da falha de enquadramento do projeto que ignorou as limitações e restrições sobre estes.

\footnotetext{
${ }^{2}$ Notas do curso Ethics of Humanitarian Design, ministrado pelo Prof. Ijlal Muzaffar, de setembro a dezembro de 2015 no Department of History of Art + Visual Culture, Rhode Island School of Design-RISD.
} 
Assim, podemos concluir que a ideia de usuário parece mais uma negação deste - uma negação da dimensão humana - que um trabalho em prol dele, pois coloca todas as idiossincrasias, o contexto, a condição histórica e social de lado. Nas definições do Campo do Design não ouvimos falar de hormônios e condições biológicas, por exemplo. Ouvimos falar de humor, sentimentos, estados emocionais, mas isto porque há um crescente movimento para este tipo de investigação com vias à realização do lucro, através de produtos e iniciativas que vendem sobretudo sentimentos positivos, como a felicidade, conforme vimos com Davies (2016) no Capítulo 3 - Da mercadoria. Ainda devemos lembrar das palavras de Greenfield (2017, p. 303) sobre o falso-deus usuário, ideia através da qual designers olham para a tecnologia e não necessariamente para a necessidade social dos seus idolatrados usuários.

Em continuação, Redström (2006) considera que, entretanto, não podemos trabalhar com a ideia de simplesmente impor objetos aos usuários: as pessoas são partes ativas do sistema, e porque são muito menos previsíveis e menos compreendidas do que os computadores e outras partes tecnológicas do sistema, elas exigem um estudo e compreensão ainda maiores. $\mathrm{O}$ autor discorre sobre a recorrente confusão entre o que estamos projetando e quem vai usar este projeto geralmente falamos que nos concentramos no segundo, mas a concentração está mesmo é no primeiro. Logo, conforme Redström (2006), não podemos confiar no conhecimento sobre uso e usuários da maneira como esse se dá no Campo do Design, pois esses se reduzem a significados e formas de um sistema - o usuário é compreendido com base em uma perspectiva centrada em objetos, a pessoa definida em relação ao objeto. Ainda, retomando a questão da impossibilidade de se projetar a/para a experiência, devemos pensar ainda na querela interno versus externo, pois a partir de sua objetivação e externalização, a experiência seria apenas um protocolo de como se deve ser, agir a partir do que foi projetado — ou seja, a noção reducionista de experiência tecnológica do Campo do Design, com a qual não concordamos.

Com efeito, após discorrer sobre o usuário, Redström (2006) aborda o uso, que consideramos aqui também ponto-chave para nosso entendimento da impossibilidade de projetar a/para a experiência. Ele questiona: pode-se perguntar sobre o que é o Design senão sobre usar? Nos nossos cotidianos, as coisas são usadas de uma forma ou de outra e, portanto, criar objetos significa que criamos 
coisas para serem usadas. Mas obviamente que existe uma diferença fundamental entre a concepção de coisas a serem usadas e tentar projetar uso ou a experiência do usuário. Com efeito, conforme o autor, dizer que designers devem abster-se de sobredeterminar os usos e usuários não quer dizer que as ideias sobre o uso não devam ser parte da nossa preocupação — ou mesmo que não sejam nossa principal preocupação -, mas que precisamos reconhecer os limites dos nossos projetos, o que estamos projetando e o que fica de fora. Redström (2006) afirma que é por isso que a suposta mudança do objeto para usuário como base para o Design é tão problemática: ela obscurece ainda mais os limites da prática do Campo. Assim, o autor postula que talvez seja melhor nos concentrarmos no objeto como experienciado, e não na experiência do objeto - uma mudança epistemológica que pode contribuir para uma visão crítica do Campo, uma vez que reconhece que as características intangíveis são claramente limitadas pelas tangíveis. Logo, postulamos que, em um pensamento semelhante, talvez devêssemos chamar o Design de Experiência de Experiência do Design, seguindo também as modalizações modernas que ainda reverberam, pois o retorno a uma suposta experiência total, holística - a qual não reconhecemos como possível, posto que sempre será limitada pela sua construção social — não se concretiza no Campo do Design.

Ainda sobre o uso, Redström (2006) questiona também as consequências de reduzir um processo complexo ao que é fácil de entender, rápido de aprender, imediatamente atraente etc. $\mathrm{O}$ que acontece quando reduzimos o espaço da interpretação pessoal de uso em nossa ambição de projetar para a eficiência, quando nosso entendimento e, de fato, os limites do conhecimento a que podemos ter acesso durante a processo de projetar para o uso, não combinam com as complexidades e sutilezas de uso real? O autor dá o exemplo de um corrimão em uma escada em via pública: o que antes estava relacionado à segurança virou insegurança com skatistas utilizando o corrimão para fazer manobras. Assim, a segurança diária é transformada em risco, onde anteriormente era precisamente o risco o que estava sendo apagado. Conforme o autor, toda a lógica, sentido ou significado do corrimão está na nossa cabeça.

Com efeito, Redström (2006) afirma que o uso que simulamos e criamos como parte de um projeto de Design — seja este interativo ou participativo — não pode lidar com o que significa algo para alguém, com o que significa um objeto 
como parte da vida de alguém. $\mathrm{O}$ autor afirma que isso não é apenas uma questão de inadequação metodológica, pois mesmo trabalhando junto de outras pessoas, só podemos trabalhar com noções abstratas de uso e experiência, uma vez que os mesmos usos podem ser vividos por agentes que chegam a conclusões diametralmente opostas - e então voltamos à supracitada questão dos limites da abstração a partir de Muzaffar (2015). Logo, conforme Redström (2006), é a inflexibilidade, o excesso de especialização, a percepção do "mundo plástico" e homogeneizado que impõe sobre nós uma vida, uma maneira obrigatória de usar o que é feito, e esta vida pode ser sentida como coerciva, não satisfatória, sem autenticidade. A supracitada facilidade de utilização ajuda a naturalizar os objetos e os valores que eles incorporam - hoje, pensa-se sobretudo na ubiquidade tecnológica, conforme Greenfield (2017). Por exemplo, ao utilizar um objeto tecnológico, esse uso é limitado pelo simples modelo generalizado de um usuário, e quanto mais tempo passamos usando-o, mais tempo passamos como uma "caricatura". Segundo Redström (2006), como as possibilidades de interpretações alternativas são sistematicamente reduzidas em virtude da tentativa do designer de otimizar o projeto quanto aos ajustes do usuário a este, o espaço para encontrar soluções próprias, possivelmente chegando com interpretações mais interessantes que as originais, é reduzido ao mínimo. E aqui podemos lembrar de Cherkasky (2003), cujo pensamento abordamos no Capítulo 2 - Da experiência, o qual afirma: "as pessoas têm experiências. Nós projetamos para elas. Quão bem os designers compreenderam a experiência daqueles que usarão os sistemas que eles implementarão? Além do mais, quão bem eles compreendem a sua própria [grifo nosso] experiência de Design"?

Ainda sobre a questão do uso, Greenfield (2017) menciona uma pesquisa feita em Londres, Tóquio e Los Angeles em $2005^{3}$, na qual foi investigado o que as pessoas levavam na bolsa antes dos smartphones e o que mudou hoje. Objetos como chave de casa, relógios, calendários e cadernos de anotações foram todos substituídos pelo dispositivo, bem como, por vezes, documentos de identificação e

\footnotetext{
${ }^{3}$ ITO, Mizuko; OKABE, Daisuke; ANDERSON, Ken. Portable Objects in Three Global Cities: The Personalization of Urban Places. In.: The Reconstruction of Space and Time: Mobile Communication Practices. Rich Ling and Scott W. Campbell, eds., Piscataway, NJ: Transaction Publishers, 2009.
} 
até mesmo dinheiro. Os únicos elementos que não foram substituídos pelo smartphones foram: i) comida e ii) produtos de higiene. Assim, por que se pode dizer que com o celular ou dispositivo digital projetamos a experiência de abrir uma porta, mas com uma chave não? Seria o projeto e o uso do app para abrir a porta considerado imaterial - superior ao uso de uma chave?

Ainda, ao contrário dos que acham que o suposto projeto da/para a experiência no Campo do Design propiciaria uma democratização desta, na verdade este não passa de uma cópia que não descentraliza o poder: ele cria, legitima e reproduz esse poder, não reconhecendo a abstração e seus limites, sendo imposto do topo para a base. Assim, a suposta experiência projetada no Campo do Design seria como uma cópia, nada autêntica — enquanto que designers e teóricos, como Pine e Gilmore (2013), clamam por sua autencidade e, nisto, confirmam sua posição de negação da história social.

Deste modo, podemos sumarizar: por que não produzimos experiências? Porque não é possível projetar algo que escapa à atividade projetual, algo que não está aí para ser projetado. Ainda que fosse possível, designers não levam em conta o que, de fato, é uma experiência - um somatório do contexto, do coletivo e do individual em um ato que é determinado histórica e socialmente. A preocupação dos designers é com a tecnologia, com o objeto tecnológico, seu uso, sua operação, e não com o usuário, nem com sua experiência. Dizemos que seu uso será eficaz, que nos deixará feliz, mas o que é ser eficaz e ser feliz? Isto não depende do objeto, mas sim das condições de espaço-tempo, do contexto, da pessoa que o utiliza e suas idiossincracias.

Logo, os objetos e serviços que projetam é que propiciam essas experiências. Não se pode projetar a experiência em si mesma, e nem para a experiência - na verdade, isso não é nada novo, pois desde que se projetam objetos, ou mercadorias está intrínseco que é seu uso que propiciará uma experiência. Neste sentido, falar de experiência consiste apenas da adoção de um "novo" termo para cumprir com as exigências do modo de produção vigente, que impõe a necessidade da ideia de inovação como vital. Devemos atentar para o fato de que a escolha do termo experiência é uma escolha política por parte dos agentes que operam no Campo, e não apenas algo que simplesmente "surgiu" no Campo. Conforme apontamos no Capítulo 2 - Da experiência, tanto na vertente humanista quanto na orientada pelo mercado - e como podemos ver também em algumas 
passagens do Capítulo 3 - Da mercadoria, em que o termo experiência é trazido à tona, como com Adorno e Horkheimer (2002), Jameson (1997) e Davies (2016) ele já cumpria antes papel de interesse e importância não só no Campo do Design, mas também nas frentes da querela cultura versus mercado. Com efeito, talvez pela sua pluralidade de sentidos e definições é que o termo experiência foi entendido como uma boa opção para ser empregada - e algo como a nova, ou última, aquisição do capitalismo sobre nossas vidas, que já leva nossos corpos no trabalho diário.

Temos então que o modo de produção capitalista influencia, e muito, nossas experiências, mas que o Campo do Design não é capaz de projetá-las, pois elas não são projetáveis. Assim, faz sentido agora nos voltarmos novamente à questão do objeto e da posição deste na sociedade - e aqui voltamos a uma discussão já presente desde a modernidade, que parece só ter tomado novos nomes e contornos, e que não se esgota - ou seja, voltamos à materialidade e sua produção de riqueza.

\section{2. \\ Vendendo promessas}

Se a experiência não pode ser projetada, o que é que o Campo do Design vende/comercializa, então? Para responder a esta pergunta, devemos primeiro definir se uma experiência pode ou não ser mercadoria. Para isso, vamos considerar o que podemos identificar como duas frentes de entendimento distintas, estas já apresentadas no Capítulo 3 - Da mercadoria: a frente que entendemos advogar pela possibilidade da experiência como mercadoria, com Adorno e Horkheimer (2002), Harvey (2010) e Jameson (1997); e a que entendemos problematizar a possibilidade do pensamento da experiência como mercadoria, com Mandel (1982) e Matias (2014), ao seguir a forma elementar a partir de Marx (2013). Devemos afirmar aqui, antes de mais nada, que não necessariamente estes autores escrevem, com todas as letras, que a experiência pode ou não ser mercadoria. O que nos leva a utilizar seu pensamento para formular essa distinção é justamente a forma como eles definem — ou não definem - o que é mercadoria. Esta distinção é possível também ao considerarmos a supracitada noção de comodificação, a partir da qual atribui-se valor econômico a algo que antes não o possuía, ou seja, que relações antes não mantidas pelo comércio são transformadas em relações econômicas, em uma 
substituição de valores sociais por valores de mercado. Entretanto, devemos atentar ao fato de que a noção de comodificação não necessariamente significa que este algo agora com valor econômico se transforma em mercadoria - aqui, é só lembrarmos dos exemplos de serviços dados por Mandel (1982), que geram lucro, mas não riqueza. Neste sentido, torna-se importante postularmos aqui que, para nosso entendimento do Campo do Design, seguiremos a posição da forma elementar, ou seja, aquela postulada por Marx (2013) e discutida por Mandel (1982) e Matias (2014), por entendermos que esta descreve e reflete de modo claro e objetivo as nuances e contradições do desenvolvimento do modo de produção capitalista às quais o Campo do Design já nasceu submetido. Assim, consideramos que a experiência não pode ser uma mercadoria, não obstante uma noção equivocada — posto que não pode ser projetada — que tenta ${ }^{4}$ lhe atribuir valor econômico no Campo do Design.

Antes de partir para o que o Campo do Design vende, talvez devamos nos demorar um pouco mais e explicar melhor por que a experiência não pode ser uma mercadoria. Se buscarmos a forma elementar em Marx (2013) - que, conforme vimos com Chauvin e Sezneva (2014), persiste até hoje, com exemplos que discutem a querela do tangível versus intangível - temos que a mercadoria é algo, um objeto externo ao homem, que por meio de suas propriedades satisfaz necessidades humanas de qualquer tipo, e que essas necessidades - sejam elas provenientes do estômago ou da imaginação - não alteram em nada a questão. Ainda, a mercadoria deve ser composta por um valor de uso, ou seja, uma utilidade, relativa à sua qualidade, e um valor de troca, este definido a partir da quantidade de trabalho humano incorporado, trabalho social necessário para a produção da mercadoria. Ainda, a utilidade de uma mercadoria é condicionada pelas propriedades do corpo da mercadoria e não existe sem esse corpo; e nenhuma coisa pode ser valor de uso sem ser objeto de uso: se ela é inútil, também o é o trabalho nela contido e, assim, não conta como trabalho e não cria, consequentemente, nenhum valor. Conforme Matias (2014), para entendermos uma mercadoria, o foco da análise não pode ser o produto "materializado" (ou não), mas o decurso de sua

\footnotetext{
${ }^{4}$ Usamos aqui o verbo tentar, e não diretamente atribuir, por considerarmos que todas as vezes em que se afirma que é a experiência é/será comercializada, o que na verdade é comercializado são serviços, como apps, ou objetos, mercadorias, como o nosso exemplo do despertador da Philips, ou seja, ela sempre ocorre/é consequência de algo tangível (despertador), ou mediado por algo intangível, mas que precisa de algo tangível (apps em dispositivos físicos).
} 
elaboração - e aqui devemos lembrar da ênfase na circulação em detrimento da produção, a qual ocorre com a flexibilização do modo de produção capitalista e a partir da qual, através de uma injeção de capital na esfera da circulação, novas mercadorias e serviços surgem. Já vimos isto com Harvey (2010) e Mandel (1982) no Capítulo 3 - Da mercadoria, e comentaremos novamente em seguida. Devemos ainda lembrar da alienação, em que as coisas são, em si, exteriores ao homem, livremente cambiáveis, e os operadores da troca não têm vínculo pessoal com as coisas que possuem.

A partir dos postulados desta definição, podemos visualizar que a maior parte dos exemplos de experiências do Campo do Design - o despertar propiciado pelo despertador da Philips, a felicidade com a mensagem do namorado no celular da mulher e abrir a porta de casa com um $a p p$ - não se encaixam na noção da forma elementar descrita por Marx (2013), salvo quando consideramos suas bases tangíveis, que muitas vezes têm seu valor econômico determinado mais por especulação que por qualidades reais. Mas quais foram as mudanças no capitalismo nos fizeram chegar até aqui? E se a experiência não é mercadoria, como chegamos até essa possibilidade de consideração de que ela seja? Já discorremos sobre isso no Capítulo 3 - Da mercadoria, mas vamos relembrar aqui alguns pontos-chave.

Vimos com Harvey (2010) que o colapso do modelo fordista-keynesiano a partir da década de 1970 - em virtude da rigidez de seu regime de acumulação trouxe novos sistemas de produção e uma expansão do marketing, junto de processos de trabalho e mercados mais flexíveis, mobilidade geográfica e rápidas mudanças práticas de consumo. Esse novo modelo de acumulação flexível e seu sistema de produção permitiram uma aceleração do ritmo da "inovação" do produto, além do crescimento do consumo, maior atenção às modas fugazes e mobilização de artifícios denominados de "novos". Ainda, a indução de necessidades, a criação de segmentos de mercado crescentemente especializados e individualizados constituíram formas de elevar os níveis de consumo e a renovação de mercadorias. Conforme o autor nos ensinou, a necessidade de acelerar o tempo de giro do consumo provocou a mudança de ênfase da produção de bens - facas e garfos, por exemplo, que têm um tempo de vida substancial - para a produção de eventos, como espetáculos, com tempo de giro quase instantâneo. Isso corresponde a uma orientação do capitalismo para a expansão dos mercados; para o crescimento econômico dependente da exploração do trabalho em condições de assalariamento 
e para a manutenção da dinâmica tecnológica e organizacional do capitalismo, todas características que podem ser vistas nas mudanças nas formas de trabalho também no Campo do Design. Com efeito, se o capitalismo tem que se expandir, sobretudo em virtude de sua superprodução e consequente liberação do trabalho, ele vai até as nossas experiências.

Mandel (1982), por sua vez, acrescenta que esse desenvolvimento constante da divisão social do trabalho é uma das causas da ampliação da discussão sobre mercadorias, pois novos trabalhos específicos surgem justamente a partir da divisão de práticas que antes eram desenvolvidas por um único trabalhador em todo o seu processo. Logo, a tendência à centralização tem caráter técnico e econômico, e funções intermediárias são sistematizadas e racionalizadas para assegurar produção e venda contínuas. Ainda, conforme nos informou o autor, longe de representar uma "sociedade pós-industrial", o capitalismo tardio constitui uma industrialização generalizada universal pela primeira vez na história, e a industrialização da esfera de reprodução constitui o ápice desse processo. Entretanto, as novas massas de capital penetram cada vez mais nas áreas não produtivas, mas não criarão maisvalor. Mandel (1982) fala do setor de serviços, que cresce a partir da disponibilidade de grandes quantidades de capital que não podem mais se valorizar na indústria propriamente dita - pois não são reaplicados a ela - e que, por isso, surge então uma grande diferenciação no consumo, especialmente no consumo dos assalariados, o que se torna também um pré-requisito dessas novas formas de acumulação. Nisto, as dificuldades de realização do mais-valor estimulam a tendência crescente dos monopólios em alterar perpetuamente a forma das mercadorias, muitas vezes de maneira absurda do ponto de vista do consumo racional, o que resulta em deterioração de qualidade.

Mandel (1982) também nos lembra de que quanto mais satisfeito o consumo efetivo de mercadorias, tanto mais irracional e indiferente ao homem se torna a sua expansão quantitativa, degenerando em pura extravagância, tédio e aversão à vida. Ele complementa que essa dimensão do consumo parece ter sido negligenciada por aqueles que nada veem de problemático na comercialização universal de "bens" e "serviços" tais como "bens culturais" e serviços de "civilização", esquecendo-se de que a produção desses bens está subordinada à motivação do lucro do comércio capitalista. Assim, consumidores têm de ser persuadidos de suas novas necessidades e designers se encaixam no crescimento do número de trabalhadores 
assalariados empregados de forma improdutiva, em virtude da penetração maciça de capital na esfera da circulação e dos serviços. E o que isso gera? Acumulação de fortunas nas mãos de quem não produziu riqueza, deslocamento do lucro e do poder econômico e financeiro dos produtores para os intermediários, para a circulação e reprodução. Assim, a prática do Design se aproxima das noções de processo, de gestão e de marketing 5 .

Com efeito, Hassenzahl (2011), em um lapso de consciência, pontua que a experiência é considerada um veículo para o marketing, e não necessariamente um produto próprio a ser vendido - aqui, podemos considerar que seja uma estratégia de marketing como qualquer outra, talvez mais extensa. Entretanto, em seguida o autor já se contradiz, ao afirmar que a transição de uma economia de produtos e serviços para uma economia de experiências exige novas configurações e esforços, que vão além dos pensamentos mais recorrentes, pois para ele, experiência ou experiência do usuário não estão relacionadas à tecnologia, ao Design de produto, ou a interfaces, mas sim à criação de uma experiência significativa através de um dispositivo.

Ainda, devemos lembrar aqui de Chauvin e Sezneva (2014), para quem os limites ou ausência de limites do capitalismo não vieram da intangibilidade per se, mas sim de novas formas de inscrição física. Os autores consideram que é justamente por o capitalismo incorporar o intangível e o virtual às esferas de produção e troca que esse modo de produção acaba por incluir em seu modus operandi mundos vitais antes não afetados pelo ciclo de acumulação do capital, fazendo perdurar esse artefato sociotécnico chamado mercadoria. Com efeito, mesmo que se considerem mercadorias imateriais, a experiência não se encaixa nessa categoria, pois ela não é como uma música, um jogo. Ela é uma decorrência destes, posto que evocam experiências, mas ela não pode ser projetada por si só. Assim, a experiência não pode ser uma mercadoria e sua adoção neste contexto determina apenas mais ação de marketing, um novo nome para as "necessidades" que o capitalismo cria. No campo do Design, o que chamam de experiência constitui apenas um valor de troca - sem valor de uso e sem valor - e também um valor simbólico, conforme veremos agora.

\footnotetext{
${ }^{5}$ Matias (2014) trata desta aproximação, ou subsunção, em Projeto e Revolução: do fetichismo à gestão, uma crítica à teoria do design. Ver referência na nota 20 do Capítulo 3 - Da mercadoria.
} 
Principiamos por lembrar Matias (2014), para quem considerar algo apenas como valor de troca evidencia a posição ideológica de ignorar o papel determinante das relações sociais de produção, além de transferir o foco da análise para a esfera da circulação, para o mercado. Conforme o autor, no Campo do Design a questão do fetiche da mercadoria fica evidente, uma vez que os "produtos" não são definidos como mercadoria, seu entendimento enquanto resultado das relações sociais de produção fica obscurecido e ele é reduzido a meras relações de "mercado". Logo, o autor evidencia que o fetichismo sofreu novas apropriações e interpretações ao longo do século XX, com ênfase na esfera da circulação/consumo, como marketing e branding - todas frentes relacionadas ao Campo do Design. Com efeito, a produção do Campo do Design configura-se, então, como mero instrumento de sedução e de convencimento, que não tem outra finalidade senão a "venda".

Neste sentido, o que vende então o Campo do Design nesta questão da experiência? Para formular esta resposta seguimos Haug (1971), que afirma que a estética da mercadoria enquanto mercadoria oferece apenas a "promessa de valor de uso". Ora, no caso do Campo do Design, temos também apenas a promessa de que o uso de um objeto ou mercadoria específicos se dará de determinado modo, e de que a experiência consequente deste será de tal modo. Quer dizer, vende-se uma promessa - que pode se realizar ou não - através de serviços e objetos/mercadorias produzidos pelo Campo. Para além do objeto e de sua forma de uso, são apenas promessas que podem não se cumprir. E essas promessas podem ser entendidas ainda como um valor simbólico, isto é, um arbitrário cultural construído socialmente para ser um conjunto de valores que confere distinção a quem o possui. Este valor não está diretamente ligado ao interesse econômico embora siga a sua direção - e a utilidade social do objeto ou bem que o carrega não é necessariamente determinada pelo seu uso.

Assim, vendemos apenas promessas de que tal experiência ocorrerá, como os exemplos de Davies (2014) vendem a promessa de felicidade, a "nova preocupação das elites globais". Essa agenda tem interesses políticos e uma dimensão ideológica claros, sobretudo ao ser apresentada como nova, caracterizando-se como uma exploração por parte daqueles que têm interesse em controle social, como vias de lucro. Devemos lembrar ainda da afirmação de Davies (2014) de que um dos argumentos fundacionais do neoliberalismo em favor do 
mercado é que este serve como um dispositivo sensorial, que captura milhões de desejos, opiniões e valores individuais e os converte em preços. Com efeito, a promessa do bem-estar, da experiência, medidos e manipulados, tornam-se apenas um meio de alcançar lucro, status ou poder.

Podemos lembrar também de algumas constatações da Escola de Frankfurt, as quais parecem ecoar até hoje. Vemos muito do postulado por Adorno e Horkheimer (2002) no Campo do Design, como as partes explicando em termos técnicos o que é imposto em virtude de interesses econômicos hegemônicos. Ainda, a ideia de que a racionalidade técnica hoje é a racionalidade da dominação também faz eco na experiência tecnologicamente determinada do Campo do Design, a qual tem seus efeitos adversos como resultado das leis internas da economia, e não necessariamente de suas questões técnicas. Entretanto, é pela imposição destas questões técnicas e sua sustentação econômica que todos devem se comportar espontaneamente de acordo com um "nível” determinado por índices, e devem selecionar categorias de produtos em massa fabricados para o seu tipo, apenas com a aparência de competição e escolha.

Com efeito, torna-se possível observar uma naturalização generalizada, uma tradução rotineira de tudo - mesmo do que ainda não foi pensado - ao esquema da reprodutibilidade tecnológica, em obediência a uma hierarquia social e às leis gerais do capital. O mercado apresenta-se como uma ideologia, e todas as necessidades impostas aos indivíduos já vêm com a solução definida pelo mercado, o qual produz, controla e disciplina as necessidades dos consumidores. Assim, os indivíduos devem suprir suas necessidades como consumidores eternos, e o interesse nos seres humanos se sustenta apenas a partir da sua concepção enquanto consumidores: o indivíduo se torna ilusório pela padronização do modo de produção e seu traço individual é reduzido à capacidade do universal. Entretanto, se postulamos aqui que a noção de experiência escapa, em certa medida, a essa capacidade do universal, haveria então a possibilidade — mesmo que remota — de um pensamento realmente humanista no Campo do Design, sobretudo ao reconhecer suas limitações e afirmar a impossibilidade de projetar a/para a experiência e a comercialização desta? Se o Campo realmente deseja ter uma posição humanista, ele deve ser crítico do modo de produção que rege o contexto, as condições e as idiossincracias das experiências que ele forja projetar. 


\section{5.}

\section{CONCLUSÃO}

"Bem, é tudo experiência, mas é uma pena que tenha sido preciso tanta." Jay (2006, p. 401) inicia a finalização de Songs of Experience: Modern American and European variations on a universal theme com esta epígrafe do livro Experience: A memoir $(2000)^{1}$, de Kingsley Amis, e a citamos aqui pois partilhamos parcialmente de seu sentimento: não obstante a ideia de experiência traga o peso da vivência acumulada — seja positiva ou negativa — ela é também sinônimo de aspirações alcançadas, lutas vencidas. Assim, o anseio de estudar algo tão imbricado em nosso cotidiano - quiçá vital à existência humana, ou parte do que nos torna humanos - não se encerra facilmente e, tendo identificado o uso equivocado do termo no Campo do Design e sua relação de subserviência ao capitalismo, restam agora outras frentes de desbravamento, tanto dentro quanto fora do Campo.

Entretanto, antes de discorrermos sobre esses desdobramentos, faz-se necessário arrazoarmos sobre até onde a experiência de escrever esta tese nos trouxe. Na nossa investigação da experiência como mercadoria no Campo do Design, acabamos por utilizar os termos experiência e mercadoria como ferramentas para o desenvolvimento de uma crítica, pois esta oferece aos pares as condições de possibilidade de estabelecermos um estatuto epistemológico para nossa área de estudos. Através desta crítica, buscamos compreender e evidenciar os limites da prática no Campo, bem como seu locus nas esferas teórica e econômica mais amplas, que regem a sociedade. Ao recorrer a uma investigação históricosocial para traçar os caminhos e desdobramentos dos empregos e usos destes termos, buscamos olhar para o Campo de fora para dentro, almejando ver o todo, e não apenas a parte - foco recorrente em teses e dissertações do Campo do Design. Ao fazer esse movimento de expansão, que é um movimento crítico, de

\footnotetext{
${ }^{1}$ AMIS, Kingsley. Experience: A memoir. New York, 2000.
} 
reconhecimento do que está além e do que nos forma, buscamos evidenciar proximidades e subserviências pouco identificadas e debatidas.

Nossa linha crítica, da Crítica Social e do Materialismo Histórico, ajudounos a localizar e identificar a raison d'être do emprego do termo experiência no Campo do Design, bem como as dinâmicas por trás desse emprego. Logo, identificar os movimentos do modo de produção capitalista e os movimentos do pensamento humano acerca da noção de experiência, que estão absolutamente intrincados, nos fizeram chegar a uma imagem mais acurada do que está em jogo na adoção de novos termos, métodos e práticas, dentro do que podemos talvez chamar de expansão capitalista do Campo do Design.

Com efeito, no Capítulo 2 - Da experiência, identificamos duas distintas vertentes, ainda que complementares, que definem e advogam pela adoção do termo. Com origem em estudos dos anos 1970 sobre a relação humano-computador até os dias atuais, em que se fala da ubiquidade dos sistemas digitais, a vertente teórica humanista postula uma preocupação com o usuário - como são definidas hegemonicamente e acriticamente as pessoas que fazem uso de sistemas e aparelhos digitais. Com efeito, pudemos evidenciar que este discurso dito humanista é vazio, posto que a preocupação projetual ainda ocorre através do objeto e de seu uso e, assim, no máximo estaríamos projetando um usuário, e não para ele. Ainda, ele é vazio por postular uma experiência holística, enquanto que o que pode oferecer é, no máximo, uma experiência determinada tecnologicamente - ou, se consideramos a tecnologia como orientada pelo capital, uma experiência determinada também pelo capital. A segunda vertente — orientada pelo mercado — torna a proximidade do Campo do Design com a busca de lucro mais evidente. Ao também postularem uma maior preocupação com os usuários, buscando saciar as suas "necessidades", mas com um posicionamento econômico mais aparente, falando do quanto estes novos projetos podem ajudar empresas e de como eles são o futuro contra a austeridade, através de novas formas de emprego e de novas demandas econômicas. Os autores levam-nos a perceber o quanto o discurso acerca das necessidades trata, na verdade, de uma invenção e imposição destas, e de quanto essas necessidades não passam de artifícios para um giro mais rápido de capital. Ainda no Capítulo 2 - Da experiência, recorremos a definições além-Campo do Design, pois necessitávamos compreender do que se trata, de fato, a experiência nas frentes do pensamento e ação humanos. Para tal, investigamos escritos que 
debatem a história do emprego do termo, seus desdobramentos e impasses desde a Antiguidade grega, o que nos fez reconhecer a complexidade e riqueza de um conceito tão vital à vida humana, posto que é parte de nosso cotidiano. Com esta investigação, vimos já no início do século XX algumas considerações e preocupações acerca da experiência como mercadoria, bem como sua modalização em distintas categorias a partir do pensamento especializado da modernidade. Por fim, vimos um conceito de experiência com bases críticas, em que esta é reconhecida como uma ocorrência tensionada entre o indivíduo e o meio, cuja definição é concebida sobretudo a partir das instâncias que regem o meio.

No Capítulo 3 - Da mercadoria, nos aventuramos por escritos da Economia Política, bem como sobre a Indústria Cultural, os novos modos de acumulação do capitalismo e as novas mercadorias da contemporaneidade, o que nos fez vislumbrar a relação estreita entre os Campos da Arte, do Design e a Economia Política. Verificamos ainda um ponto crucial na pouco abordada discussão acerca do que é mercadoria hoje - a ideia de comodificação, que atribui valor de mercado a um objeto, mas não necessariamente o torna uma mercadoria. Esta noção, quando não trazida à tona, causa confusão na definição do que, de fato, realmente gera riqueza na sociedade. Ainda, a dimensão do trabalho na definição de uma mercadoria, aqui abordada superficialmente, se mostra um importante componente para seu entendimento - e pensamos então na dimensão do trabalho e suas condições no Campo do Design. Para o seguimento do estudo, evidenciamos nossa escolha por compreender a mercadoria hoje a partir de sua forma elementar, o que nos fez concluir que a experiência não pode ser uma mercadoria. No Campo do Design, ela não pode ser uma mercadoria até mesmo porque não é projetada.

Esta constatação nos levou à crítica, no Capítulo 4 - Crítica da experiência como mercadoria no Campo do Design, em que nos posicionamos sobre nosso entendimento de experiência - como construção social — e mercadoria - como seguindo sua forma elementar, as quais nos levaram a postular que a experiência não pode ser projetada, nem se pode projetar para a experiência, posto que isto é algo que não está ao alcance dos designers - e evidenciamos até mesmo como a noção de usuário e de projeto para o uso são problemáticas e o quanto, em última instância, ainda a materialidade de objetos é o que cerceia e orienta nosso trabalho; bem como evidenciamos que o que vendemos, já que não são experiências, só podem ser promessas de um uso ou experiência através de objetos e serviços. Deste 
modo, tentamos desmontar a ideia de que os designers projetam a/para a experiência, bem como a ideia de que esta é uma mercadoria. No Capítulo $2-D a$ experiência, vimos como muitos teóricos já protestavam contra a ideia da experiência como mercadoria, mas o faziam/fazem por motivos equivocados, por achar que esta tem de ser autêntica e, por isso, não deve ser massificada. Entretanto, não enxergam além, para perceber que o resultado de um projeto é sempre algo externo que, de certo modo, homogeneíza o que produz para o consumo.

Com efeito, buscamos também ter identificado o emprego de termos no Campo do Design como um ato político, que delineia estratégias e orientações ideológicas, ainda que invisivelmente, e que diz respeito também ao desenvolvimento do modo de produção em que vivemos, o qual parece ser apagado na maior parte das discussões do Campo do Design. No todo das teorias apresentadas, pudemos perceber que os designers já mostram o que realmente negam, que os interesses ideológicos e formas de subjetividade constituem o terreno social sob o qual se produz o Design - e este terreno social é sistematicamente negado.

Para futuros desdobramentos, pensamos em ampliar os estudos sobre as noções de experiência e mercadoria, com o intuito de detalhar de forma mais minuciosa os embates existentes. Sobre experiência, compreender melhor as modulações existentes a partir da Idade Moderna e seus possíveis pontos críticos em relação ao Campo do Design. Sobre mercadoria, um estudo que dê conta da dimensão do trabalho hoje, sobretudo no Campo do Design - o que define o nosso trabalho, o que produzimos, com que finalidade, com fins à tentativa de definição de um estatuto epistemológico da prática social do Campo. Ainda, conversas e entrevistas com designers que projetam a/para a experiência, com o intuito de questioná-los se realmente acreditam no que fazem, ou se o fazem por necessidade. Este desdobramento específico pode, em um primeiro momento, apresentar ares ingênuos, entretanto, é somente através da discussão e de exemplos concretos que melhor conseguimos compreender nossa posição, suas causas e consequências.

Por fim, não desejamos que nosso trabalho seja entendido como uma história definitiva do que é postulado. O movimento que empreendemos aqui, e que procuraremos empregar em trabalhos futuros, é o que Marx (2013) já definiu como um ato histórico: encontrar as medidas sociais das coisas, posto que sem essa percepção, ou seja, com uma percepção reduzida e anistórica das coisas do mundo, 
perdemos em uma compreensão de sua verdadeira raison d'être. Se a experiência de escrever esta tese, como mencionamos ao início desta conclusão e na introdução, nos ensinou algo, se saímos daqui mais experientes que inocentes, como postula Blake (1789), é que um pensamento crítico é sempre — e cada vez mais necessário, posto que entendimentos pontuais funcionam quase como oásis na imensidão da cacofonia intelectual e mercadológica atuais. Se de fato chegamos a isto, é a experiência do leitor que dirá. 
6. Referências bibliográficas

ABBAGNANO, Nicola. Dicionário de Filosofia. $2^{\text {a }}$ edição. São Paulo: Martins Fontes, 1998.

ADORNO, Theodor. W. Aesthetic Theory. Minneapolis, 1997. Negative Dialectics. New York, 1973. . Notes on Literature. Vol. 2. Columbia University Press, 1992.

ADORNO, Theodor W.; HORKHEIMER, Max. Dialectic of Enlightenment: Philosophical Fragments. Stanford University Press, 2002.

AMIS, Kingsley. Experience: A memoir. New York, 2000

ANDERSON, Eric. Hans Makart's Technicolor Dream House: Decoration and Subjectivity in Nineteenth-Century Vienna. In.: West 86th: A Journal of Decorative Arts, Design History, and Material Culture, no. 22(1). SpringSummer, 2015.

ARGAN, Giulio Carlo. A História na Metodologia do Projeto. In: Revista Caramelo. No. 6, FAU/USP, 1992.

BATTARBEE, Katja; KOSKINEN, Ilpo. Co-experience: user experience as interaction. In.: CoDesign, Vol. 1, No. 1, March 2005.

BENJAMIN, Walter. Experience and Poverty (1933). In: Selected Writings, vol. $2,2005$. Little History of Photography (1931). In: Selected Writings, vol. 2, 2005. The Return of the Flaneur (1929). In: Selected Writings, vol. 2, 2005. A obra de arte na era da reprodutibilidade técnica. In.: Adorno et alii. Teoria da Cultura de Massa. São Paulo: Paz e Terra, 2000. On some motifs in Baudelaire (1939). In: Illuminations, 1969. BERGER, John. Ways of Seeing. Penguin, 1972. 
BLAKE, William. Songs of Innocence and of Experience: showing the two contrary states of the human soul. Oxford University Press, 1967.

BOURDIEU, Pierre. O poder simbólico. Rio de Janeiro: Bertrand Brasil, 2003.

2001. A economia das trocas simbólicas. São Paulo: Perspectiva,

BOVEN, Leaf Van; GILOVICH, Thomas D. To Do or to Have? That Is the Question. In.: Journal of Personality and Social Psychology, 85 (6), 2003

BÜRGER, Peter. Some Reflections upon the Historico-Sociological Explanation of the Aesthetics of Genius in the Eighteenth Century. In.: The Decline of Modernism, trans. Nicholas Walker. University Park, 1992.

BURK, Dan L. Legal Constraint of Genetic Use Restrictions Technologies. In.: Minnesota Journal of Law, Science \& Technology, 2004.

BUXTON, Bill. Sketching User Experiences: Getting the Design Right and the Right Design. Morgan Kaufmann, 2007.

CANNING, Kathleen. Feminist History after the Linguistic Turn: Historicising Discourse and Experience. In: Signs 19, no. 2, 1994.

ČARGONJA, Hrvoje. Ambiguous Experience: A Contribution to Understanding Experience as Discourse. Stud. ethnol. Croat., vol. 23, str. 283308, Zagreb, 2011

CARTER, Travis J.; GILOVICH Thomas D. The Relative Relativity of Material and Experiential Purchases. In.: Journal of Personality and Social Psychology, 98 (0), 2010.

CASTELlS, Manuel; CARDOSO, Gustavo. The Network Society: From Knowledge to Policy. Washington, DC: John Hopkins Center for Transatlantic Relations, 2006.

CHAUVIN, Sébastien; SEZNEVA, Olga. Has Capitalism Gone Virtual? Content Containment and the Obsolescence of the Commodity. In.: Critical Historical Studies, no. 1 (Spring 2014).

CHERKASKY, Todd. Designing Experience. In.: International Journal of Engineering Education. Vol. 19, No. 1, 2003.

CIPINIUK, Alberto. O Campo do Design e a crise do monopólio da crença. São Paulo: Blucher, 2017.

Design: o livro dos porquês: o campo do Design compreendido como produção social. Rio de Janeiro: Ed. PUC-Rio; São Paulo: Ed. Reflexão, 2014. 
CSIKSZENTMIHALYI, Mihaly. Flow: The psychology of optimal experience. New York: Harper and Row, 1991.

DAVIES, Williams. The Happiness Industry: how the government and big business are selling us sell-being. Verso E-Book, 2016.

DEMIR, Erdem. The field of design and emotion: concepts, arguments, tools, and current issues. In.: Journal of the Faculty of Architecture (METU JFA), no. 25(1), 2008.

DESMET, Pieter; HEKKERT, Paul. Framework of product experience. In.: International Journal of Design, v. 1, n. 1, 2007.

DEWEY, John. Art as Experience. New York: Perigee, 1980.

DILTHEY, Wilhelm. Introduction to the Human Sciences: an attempt to lay a foundation for the study of society and history. Detroit, 1988.

EAGLETON, Terry. A ideologia da Estética. Rio de Janeiro: Jorge Zahar Editores, 1993.

Encyclopedia of Marxism: https:/www.marxists.org/glossary/terms/c/o.htm. Acesso em 28 de Fevereiro de 2018.

FOGG, Brian .J. Persuasive technologies. Communications of the ACM, 1999.

FORLIZZI, Jodi; BATTARBEE, Katja. Understanding experience in interactive systems. DIS 2004. New York, USA: ACM Press, 2004.

FORLIZZI, Jodi.; FORD, Shannon. The building blocks of experience: an early framework for interaction designers. DIS 2000 Conference, ACM, 2000.

FORTY, Adrian. Objetos de Desejo: Design e Sociedade desde 1750. São Paulo: Cosac Naify, 2007.

FRIED, Michael. Art and Objecthood: Essays and Reviews. Chicago, 1998.

GALLUP. State of the Global Workplace Report 2013. 2013.

GOFFMAN, Erving. The Presentation of Self in Everyday Life. New York: Anchor Books, 1959.

GOLDMAN, Alan. The Aesthetic. In.: The Routledge companion to aesthetics. London: Routledge, 2001.

GREENFIELD, Adam. Radical Technologies: the Design of everyday life. Verso, 2017 
GREFÉ, Richard. (Form + Content + Context $)$ Time $=$ Experience Design. In.: Gain: AIGA Journal of Design for the Network Economy. Volume 1, number 1,2000 .

HARVEY, David. Para entender O Capital. São Paulo: Boitempo, 2013.

Condição pós-moderna: uma pesquisa sobre as origens da mudança cultural. São Paulo: Edições Loyola, 2010.

HASSENZAHL, Marc. User Experience and Experience Design. In: Encyclopedia of Human-Computer Interaction. The Interaction Design Foundation, 2011.

Morgan \& Claypool, 2010.

Experience Design: technology for all the right reasons.

HASSENZAHL, Marc; TRACTINSKY, Noam. User experience - a research agenda. In: Behaviour \& Information Technology, Vol. 25, No. 2, March-April 2006.

HAUG, Wolfgang Fritz. Crítica da estética da mercadoria. São Paulo: UNESP, 1997.

HEIDEGGER, Martin. Hegel's concept of experience. New York, 1970.

HEINRICH, Fabiana Oliveira. Design: crítica à noção de metodologia de projeto. Dissertação de Mestrado. Orientador: Alberto Cipiniuk. Pontifícia Universidade Católica do Rio de Janeiro, Departamento de Artes e Design, 2013

HEKKERT, Paul. Design aesthetics: Principles of pleasure in product design. In.: Psychology Science, 48(2), 2006.

Houaiss 3.0, junho de 2009. Instituto Antônio Houaiss. Produzido e distribuído pela Editora Objetiva Ltda.

HUME, David. 'Of the standard of taste', in Essays, Literary, Moral, and Political. London: Ward, Loch, \& Co, 1757.

HUXLEY, Rich. Music is Not Our Currency, 2010. Disponível em: http://www.creativedeconstruction.com/2010/05/music-is-not-our-currency/ Data de acesso: 29 de maio de 2016.

IIDA, Itiro. Ergonomia: Projeto e Produção. São Paulo: Edgard Blücher, 2005.

INGLEHART, Ronald. Modernization and Postmodernization: Cultural, Economic, and Political Change in 43 Societies. Princeton University Press, 1997.

ITO, Mizuko; OKABE, Daisuke; ANDERSON, Ken. Portable Objects in Three Global Cities: The Personalization of Urban Places. In.: The Reconstruction of 
Space and Time: Mobile Communication Practices. Rich Ling and Scott W. Campbell, eds., Piscataway, NJ: Transaction Publishers, 2009.

JAMESON, Fredric. Pós-modernismo: a lógica cultural do capitalismo tardio. São Paulo: Ática, 2007.

JAUSS, Hans Robert. Aesthetic Experience and Literary Hermeneutics. Minneapolis: University of Minnesota Press, 1982.

JAY, Martin. Songs of Experience: Modern American and European Variations on a Universal Theme. University of California Press, 2006.

JORDAN, Patrick. W. Designing pleasurable products: an introduction to the new human factors. CRC Press Taylor \& Francis, 2002.

KANT, Immanuel. The critique of judgement. (Originalmente publicado em 1790). Oxford: Clarendon Press, 1952.

KRIEGER, Murray. Arts on the Level: the Fall of the Elite Object. Knoxville, Tennessee, 1981.

KURTGÖZÜ, Aren E. From Function to Emotion: A Critical Essay on the History of Design Arguments. In.: The Design Journal, 6(2), 2003.

LAURENTIS, Teresa. Alice doesn't: Feminism, Semiotics, Cinema. Bloomington: Indiana University Press, 1984.

LAZZARATO, Maurizio. Immaterial Labour. In.: Virno and Hardt, Radical Thought, 1996

LEE, Jung-Joo. Culture and Co-experience: Cultural Variation of User Experience in Social Interaction and Its Implications for Interaction Design. In.: Aykin N. (eds) Internationalization, Design and Global Development. IDGD 2009. Lecture Notes in Computer Science, vol 5623. Springer, Berlin, Heidelberg, 2009.

LIM Y. et al. Emotional Experience and Interaction Design. In.: Affect and Emotion in Human-Computer Interaction. Lecture Notes in Computer Science, vol 4868. Springer, Berlin, Heidelberg, 2008.

LÖBACH, Bernd. Design Industrial: Bases para a configuração dos produtos industriais. São Paulo: Edgard Blücher, 2001.

LUKÁCS, Georg. História e consciência de classe: Estudos sobre a dialética marxista. São Paulo: Martins Fontes, 2003.

MANDEL, Ernst. O Capitalismo Tardio. São Paulo: Abril Cultural, 1982.

MARX, Karl. O Capital: crítica da economia política. Livro I: o processo de produção do capital. São Paulo: Boitempo, 2013. 
MARX, Karl; ENGELS, Friedrich. Manifesto Comunista. São Paulo: Boitempo, 2007.

MARX, Karl. Preface to A Contribution to the Critique of Political Economy. In.: The Marx-Engels Reader, 2nd ed., ed. Robert C. Tucker. New York: Norton, 1978.

Theories of Surplus Value, v.1. Londres, 1972

MATIAS, Iraldo Alberto Alves. Projeto e Revolução: do fetichismo à gestão, uma crítica à teoria do design. Tese de Doutorado, Instituto de Filosofia e Ciências Humanas, Universidade Estadual de Campinas. Campinas, 2014.

MCCARTHY, John; WRIGHT, Peter. Experience-centered design: designers, users, and communities in dialogue. Morgan \& Claypool, 2010.

2004

Technology as Experience. MIT Press,

MCDERMOTT, John J. The Culture of Experience: Philosophical Essays in the American Grain. New York, 1976.

MCLELLAN, Hilary. Experience design. In.: CyberPsychology \& Behavior, v. 3, n. $1,2000$.

MÉSZÁROS, István. Para além do capital: rumo a uma teoria da transição. São Paulo: Boitempo/ UNICAMP, 2002.

MITCHELL, C. Thomas. Redefining designing; from form to experience. Van Nostrand Reinhold, New York, USA, 1993.

MOULIER-BOUTANG, Yann. Cognitive Capitalism. Cambridge: Polity Press, 2012

MUSIL, Robert. The Man without Qualities. (Originalmente publicado em 1930). Vol. 1, trans. Sophie Wilkins, New York, 1996.

MUZAFFAR, Ijlal. Anotações da disciplina Ethics of Humanitarian Design, do Department of History of Art + Visual Culture, Rhode Island School of Design. Providence, 2015.

NORMAN, Donald. A. The design of everyday things. Basic Books, 2013.

OGILVY, James. The Experience Industry: A Leading Edge Report from the Values and Lifestyles Program. In.: CA: SRI International Business Intelligence, 1985.

OVERBEEKE, Kees C. J.; WENSVEEN, Stephan A. G. Reflection on pleasure: From perception to experience, from affordances to irresistibles. In.: Proceedings of the DPPI03 Conference, ACM, 2003. 
PINE, B. Joseph. II; GILMORE, James. The experience economy: past, present and future. In.: Handbook on the Experience Economy. Edward Elgar, 2013.

. The experience economy: Work is

theater and every business a stage. Cambridge, MA: Harvard Business Press, 1999

. Welcome to the Experience Economy.

In.: Harvard Business Review, July-August, 1998.

QUARESMA, Manuela. UX Designer: quem é este profissional e qual é a sua formação e competências? In.: Design para acessibilidade e inclusão. São Paulo: Blucher, 2018.

QUINN, James B. Intelligent Enterprise: A Knowledge and Service Based Paradigm for Industry. New York: The Free Press, 1992.

REDSTRÖM, Johan. Towards user design? On the shift from object to user as the subject of design. In.: Design studies, 27(2), 2006.

REEVES, Byron; NASS, Clifford. The media equation. Cambridge, UK: Cambridge University Press, 1996.

RICHTER, Gerhard. Anotações da disciplina What is Critique, do Department of German Studies, Brown University. Providence, 2015.

RIFKIN, Jeremy. The Age of Access: The New Culture of Hypercapitalism, Where all of Life is a Paid- for Experience. New York: Jeremy P. Tarcher and Putnam, 2000.

ROLF, Jensen. The Dream Society. New York: McGraw- Hill, 1999.

SCHANK, Roger. Tell me a story: A new look at real and artificial memory. New York: Scribners, 1991.

SCHULZE, Gerhard. Die Erlebnisgesellschaft: Kultursoziologie der Gegenwart. Frankfurt am Main: Campus Verlag, 1992.

SCOTT, Joan W. The Evidence of Experience. In: Critical Inquiry 17, no 4, Summer, 1991.

SELLE, Gert. Ideología y utopía del diseño: contribución a la teoría del diseño industrial. Barcelona: Gustavo Gili, 1973.

SEYBOLD, Patricia. Customers.com. New York: Times Business, 1998.

SHEDROFF, Nathan. Experience Design 1.1. Waite Group Press, 2001.

SHUSTERMAN, Richard. Pragmatist Aesthetics: Living Beauty, Rethinking Art, 2nd ed. Rowman and Littlefield, Boston, MA, 2000. 
SPIVAK, Gayatri C. Can the Subaltern Speak? In: Marxism and the Interpretation of Culture. London: Macmillan, 1988.

STUHR, John J. Genealogical Pragmatism: Philosophy, Experience and Community. Albany, N.Y., 1997.

SURI, Jane F. The Experience of Evolution: Developments in Design Practice. In.: The Design Journal, v. 6, n. 2, 2003.

THACKARA, John (ed). Design after modernism: beyond the object. Thames and Hudson, New York, USA, 1988.

THOMPSON, Edward. P. E. P. Thompson, History from Below. Times Literary Supplement, 7 April 1966.

TOFFLER, Alvin. Future Shock. New York: Bantam Books, 1970.

WELSCH, Wolfgang. Undoing Aesthetics. London: Sage, 1997.

WESTBROOK, Robert. John Dewey and American Democracy. Cornell University Press, 1991.

WIGGERSHAUS, Rolf. The Frankfurt School: Its History, Theories, and Political Significance. MIT Press, 1994.

WILLIAMS, Raymond. Keywords: a vocabulary of culture and society. London, 1976.

The Long Revolution. London, 1961.

Culture and Society. New York, 1958.

WRIGHT, Peter; WALLACE, Jayne; MCCARTHY, John. Aesthetics and experience-centered design. In.: ACM Transactions on Computer-Human Interaction, Vol. 15, No. 4, Article 18, November 2008

\section{SITES}

Amazon Go. www.amazon.com/b?ie $=$ UTF8\&node=1600858901. Acesso em 3 de Março de 2018.

Better World by Design. www.betterworldxdesign.com. Acesso em 16 de Março de 2018.

CAMPBELL; SIMONS. At Davos, Rising Stress Spurs Goldie Hawn Meditation Talk. https://www.bloomberg.com/news/articles/2014-01-20/atdavos-rising-stress-spurs-goldie-hawn-meditation-talk, 21 January 2014. Acesso em 16 de Março de 2018. 
Center for Food Safety, Seed Giants vs. U.S. Farmers. http://www.centerforfoodsafety.org/reports/1770/seed-giants-vs-us-farmers., 13 February 2013. Acesso em 16 de Março de 2018.

CHALMERS, Robert. "Matthieu Ricard: Meet Mr. Happy". www.independent.co.uk, 18 February 2007. Acesso em 16 de Março de 2018.

Department for Culture, Media \& Sport. Understanding the Drivers, Impacts and Value of Engagement in Culture and Sport. www.gov.uk/government/publications, 2010. Acesso em 16 de Março de 2018.

Economics and Statistics Administration and United States Trademark and Patent Office, U.S. Department of Commerce, Intellectual Property and the U.S. Economy: Industries in Focus. www.uspto.gov/about/ipm/industries_in_focus.jsp, March 2012. Acesso em 16 de Março de 2018.

IDEO. www.ideo.com. Acesso em 9 de março de 2018.

Life Celebrates 10-Year Anniversary. In.: Press Release Archive, Linden Lab, http://lindenlab.com/releases/second-life-celebrates-10-year-anniversary. 20 June 2013. Acesso em 16 de Março de 2018

Looking for a Lesson in Google's Perks.

www.nytimes.com/2013/03/16/business/at-google-a-place-to-work-and-play.html. Acesso em 3 de Março de 2018.

WALKER, Chris. Second Life's Strange Second Life. In.: The Verge. http://www.theverge.com/2013/9/24/4698382/second-lifes-strange-second-life, 2013. Acesso em 16 de Março de 2018. 